\title{
On the etiology of mental retardation: the clinical genetic approach
}

Citation for published version (APA):

Moog, U. (2005). On the etiology of mental retardation: the clinical genetic approach. [Doctoral Thesis, Maastricht University]. Maastricht University. https://doi.org/10.26481/dis.20051111um

Document status and date:

Published: 01/01/2005

DOI:

10.26481/dis.20051111um

Document Version:

Publisher's PDF, also known as Version of record

\section{Please check the document version of this publication:}

- A submitted manuscript is the version of the article upon submission and before peer-review. There can be important differences between the submitted version and the official published version of record.

People interested in the research are advised to contact the author for the final version of the publication, or visit the DOI to the publisher's website.

- The final author version and the galley proof are versions of the publication after peer review.

- The final published version features the final layout of the paper including the volume, issue and page numbers.

Link to publication

\footnotetext{
General rights rights.

- You may freely distribute the URL identifying the publication in the public portal. please follow below link for the End User Agreement:

www.umlib.nl/taverne-license

Take down policy

If you believe that this document breaches copyright please contact us at:

repository@maastrichtuniversity.nl

providing details and we will investigate your claim.
}

Copyright and moral rights for the publications made accessible in the public portal are retained by the authors and/or other copyright owners and it is a condition of accessing publications that users recognise and abide by the legal requirements associated with these

- Users may download and print one copy of any publication from the public portal for the purpose of private study or research.

- You may not further distribute the material or use it for any profit-making activity or commercial gain

If the publication is distributed under the terms of Article $25 \mathrm{fa}$ of the Dutch Copyright Act, indicated by the "Taverne" license above, 
On the etiology of mental retardation

The clinical genetic approach 
Cover design: F. van der Lubbe

Layout \& print: Datawyse / Universitaire Pers Maastricht

Copyright $(\mathcal{C}$ U. Moog, Maastricht 2005 ISBN 90527804892 


\section{On the etiology of mental retardation}

\section{The clinical genetic approach}

\section{PROEFSCHRIFT}

ter verkrijging van de graad van doctor

aan de Universiteit Maastricht,

op gezag van de Rector Magnificus, Prof. mr. G.P.M.F. Mols, en volgens het besluit van het College van Decanen,

in het openbaar te verdedigen

op vrijdag 11 november 2005 om 16.00 uur

door

Ute Moog

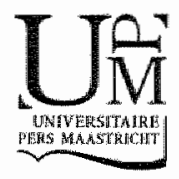




\section{PROMOTORES}

Prof. dr. J.P. Fryns

Prof. dr. C.T.R.M. Schrander-Stumpel

Prof. dr. J.P.M. Geraedts

\section{BEOORDELINGSCOMMISSIE}

Prof dr. L.J.I. Zimmerman (voorzitter)

Prof dr. B.C.J. Hamel (UMC St. Radboud Nijmegen, Nederland)

Prof. dr. P.M. Steijlen

Prof. dr. A. Verloes (Université Paris 7, France)

Prof. dr. J.S.H. Vles 
to Prof. dr. Helnum $W . J$. Moog 


\section{CONTENTS}

1 INTRODUCTION

1.1. Definition and epidemiology of mental retardation 10

1.2 Care of mentally retarded people in the Netherlands 11

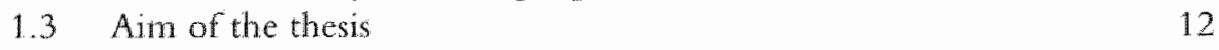

2 ETIOLOGY OF MENTAL RETARDATION

The outcome of diagnostic studies on the etiology of mental retardation: Considerations on the classification of the causes

3 CLINICAL STUDIES

3.1 Clinical evaluation 30

3.2 Example of syndrome delineation:

Oculocerebrocutaneous syndrome: the brain malformation defines a core phenotype

4 CYTOGENETIC STUDIES

4.1 Evolution of techniques $\quad 68$

4.2 Benefit of combined techniques:

Chromosome bands and ends revisited 77

4.3 Subtelomeric chromosome aberrations: still a lot to learn 81

4.4 Prevalence of cytogenetic aberrations in mental retardation 101

5 MOLECULAR STUDIES

5.1 X-linked and autosomal forms of mental retardation diagnosed by molecular investigation

5.1.1 Fragile $X$ syndrome

5.1.2 X-linked mental retardation syndromes other than

Fragile $X$ syndrome

5.1.3 Syndromic and non-syndromic X-linked mental retardation 105

5.14 A

5.1.4 Autosonal forms of mental tetardation

5.2 MECP2 related disorders in male patients

5.2.1 Neurodevelopmental disorders in males related to the gene causing Rett syndrome in females (MECP2)

5.2 .2 MECP2 mutations are an infrequent cause of mental retardation associated with neurological problems in male patients 
6 METABOLIC STUDIES

To test or not to test? Metabolic testing in mentally retarded. adolescent and adult patients

7 GENERAL DISCUSSION

7.1 Benefit of genetic evaluation of mental retardation 166

$\begin{array}{lll}7.2 & \text { Future perspectives } & 168\end{array}$

$\begin{array}{ll}\text { SUMMARY } & 177\end{array}$

SAMENVATTING 181

$\begin{array}{ll}\text { ACKNOWLEDGEMENTS } & 185\end{array}$

$\begin{array}{ll}\text { CURRICULUM VITAE } & 187\end{array}$

$\begin{array}{ll}\text { PUBLICATIONS } & 189\end{array}$ 


\section{INTRODUCTION}

1.1 Definition and epidemiology of mental retardation 10

1.2 Care of mentally retarded people in the Netherlands 11

1.3. Aim of the thesis 12 


\subsection{Definition and epidemiology of mental retardation}

Mental retardation (MR) is a lifelong disability with a major impact on an individual's life. The condition also determines the life of the whole family to a Jarge extent, as well as the interaction of the affected individual with society. As it affects a considerable proportion of the population, and demands a substantial part of health care services, MR is of major concem to society as a whole.

The understanding of MR has undergone substantial changes during the $20^{\text {th }}$ century. The institution model aimed at separating mentally retarded persons from society, and was discarded for the community model which aspired to integrating them as far as possible. The support model favoured today focuses on the limitations in individual functioning, and the resulting needed supports (Bradley \& Knoll, 1995; Schalock and Luckasson, 2004).

Definitions of MR have been given by the American Association on Mental Retardation (AAMR), the Diagnostic and Statistical Manual of Mental Disorders (4th version, DSM-4) of the Amerian Psychiatric Association (1994) and the International Classification of Diseases (ICD) of the World Health Organisation (WHO). Each of these definitions are widely accepted, and all include three basic criteria (Luckasson et a]., 1992):

- significantly subaverage intellectual functioning (IQ $<70$ );

- significant adaptive limitations in several skill areas, such as communication, selfcare, the ability to live independenly, social skills, the ability to use public services, self direction, academic skills, work, leisure, health, and safety;

- manifestation before 18 years of age.

The most recent AAMR definition is "Menal retardation is a disability characterized by significant linitations both in intellectual functioning and in adaptive behavior as expressed in conceptwal, social and practical adaptive skills. The disability originates before age 18" (AAMR 2002). In addition, the DSM-4 classification defines various levels of severity which are widely used in practice:

- Mild MR: IQ (50-55) - 70

- Moderate MR: IQ (35-40)-(50-55)

- Severe MR: IQ (20-25) - (35-40)

- Deep MR: IQ below (20-25)

The DSM-4 classification involves ranges of IQs, which indicates that the levels are overlapping sections of a spectrum of grades of severity.

Published rates of prevalence of MR vary considerably. That established by the WHO is close to $3 \%$. However, several studies have found lower rates: $1.2 \%$ in Canada (MacLaren \& Bryson, 1987); 1.14\% on average in the USA, with a signif- 
icant wariation between the individual states (Curry et al., 1997; King etal., 1997); $1.13 \%$ in South Carolina (Stevenson \& Schroer 1996); 1,2\% in Atlanta (Murphy et al., 1995); 0.77\% in British Columbia (Baird \& Sadovnick, 1985); and 0.7\% in Sweden (Hagberg \& Kyllerman, 1983). In January 2001, at least 111,750 people with MR were living in the Netherlands, consistent with a prevallence of MR of about 0.7\%-0.8\% (Van Schrojenstein Lantman-de Valk et al., 2002a).

Most studies on prevalence distinguish between mild (IQ 50-70) and severe (IQ <50) MR. Roeleveld et al. (1997) reviewed critically 43 studies performed since 1960 , and determined a relatively constant prevalence of $0.38 \%$ for severe $M R$; in contrast, the prevalence rate for mild MR was widely variant, with an average of $3 \%$. The method of identifying people with MR, the age of the study population with a peak prevalence of MR usually around age 10 years, and the assessment criteria are all variables which critically influence the outcome of the various studies (Roeleveld et al., 1997). These differences preclude an objective deternination of the prevalence of mild $M R$.

In most studies on MR, an excess of male individuals has been documented in particular for mild MR, with a male/female ratio ranging from 1.25:1 to $2.1: \mathbb{1}$ (Murphy et al., 1995; Stevenson \& Schroer, 1996; Roeleveld et al., 1997). This male predominance is (partly) caused by genes on the X-chromosome. During the last few years, knowledge on X-linked causes of syndromic and nonsyndromic MR has dramatically increased.

\subsection{Care of mentally retarded people in the Netherlands}

In 1996 , about $25 \%$ of the mentally retarded persons in the Netherlands lived in an institutional residential setting, $17 \%$ lived in small community-based residential supports (e.g. GVT, Gezins Vervangend Tehuis), and $58 \%$ lived at home with their families (Kommer et al., 1999). In 2001, five years later, the proportion of individuals living at home had decreased slightly to $53 \%$; the remaining $47 \%$ lived in a residential setting, but with a remarkable increase in the proportion living in various forms of small community-based groups (van Schrojenstein Lantman-de Valk et al., 2002a). It is expected that an additional 10.000 individuals with MR will move from institutions to small-scale housing in the coning years.

In the Netherlands, a general practitioner (GP) is most often the central medical care provider for persons with MR, in particular when these live at home or in a small-scale community-based housing. In contrast, specialised Plnysicians for Persons with Intellectual Disabilities (Arts voor Verstandelijk Gehandicapten, AVG) often serve institutions for mentally retarded people in the Netherlands. This medical specialisation was founded in the Netherlands in 2000 . It requires a 
training period of three years, which includes a facultative residence for several months at a Department of Clinical Genetics.

Mentally retarded individuals have twice as many health problems as people without MR (van Schrojenstein Lantman-de Valk et al., 2000b; Jansen et al., 2004). This may be complicated by communication problems which can be due to sensory impaiment but can also have many other causes (Meijer et al, 2004). The specific health needs of individuals with MR require both specialised and adapted primary health care. Recently, the core elements of adequate primary health care for individuals with $M R$ were proposed in a first European Manifesto (Meijer et al., 2004).

The health problems of mentally retarded persons are, however, party related to the underlying causes of their individual $\mathrm{MR}$. Consequently, the provision of appropriate preventive management depends strongly on an understanding of the cause of MR. In addition, the nature of the psycho-social care provided may depend on knowledge of the cause of the MR, particularly as developmental and behavioral profiles become known for an increasing number of MR syndromes. The clinical genetic evaluation of MR thus is an important part of specialist care for mentally retarded persons.

\subsection{Aim of the Thesis}

This thesis aims at providing an overview of the current state of the art of diagnostic investigation in $\mathrm{MR}$, focusing on the clinical genetic approach. The goal is to illustrate the clinical evaluation as well as representative parts of cytogenetic, molecular and metabolic investigations. In Chapter 2 , recent studies on the etiology of MR are critically reviewed, and the term "diagnosis" is discussed. A novel and dynamic method of classification of the causes of MR is proposed. A protocol for the clinical genetic evaluation in MR is presented in Chapter 3 . The goal is to highlight: (1) a multi-disciplinary approach; and (ii), the particular significance and importance of clinical examinations for defining syndromes, for determining further diagnostic procedures by laboratory testing, and for research purposes. This appronch is illustrated by the presentation of a particular syndrome (oculocerebrocutaneous syndrome) and its associated pattem of brain malformations. Chapter 4 focuses on chromosome analysis in the mentally retarded. It gives a summary of the evolution of different techniques and illustrates the benefit of combined techniques. It also reviews cryptic subtelomeric chromosome abnormalities found at the Department of Clinical Genetics in Mastricht. Causes of MR which can be diagnosed by molecular studies are discussed in Chapter 5 . Fragile $X$ and other $X$-linked syndromes, as well as important autosomal MR syndromes are briefly presented. The relationship between syndromic and nonsyndromic $X$-linked MR is discussed, and is exemplified by a study on MECP2 
related disorders in male patients. In Chapter 6 , the contribution of metabolic studies to the evaluation of adult persons with MR is examined. Completing the considerations of different aspects of diagnostic evaluation of MR, Chapter 7 deals with the benefits of the investigations discussed in previous chapters, and discusses future perspectives.

This thesis is thus based both on research which has been previously published, and on new research which will be presented here. It is hoped that it will serve as a practical tool for care-providers for mentally retarded persons, such as Physicians for Persons with Intellectual Disabilities (AVGs), clinical geneticists, GPs, and pediatricians.

\section{REFERENCES}

American Association on Mental Retardation. 2002. Mental Retandation. Definition, Classification, and Systems of Support, 10 $0^{\text {h }}$ ed. AAMR. Wasington, DC.

American Psychiatric Association. 1994. DSM-IV, Diagnostic Criteria. Washington, DC: APA, pp 39-46.

Baird PA, Sadovnick AD. 1985. Mental retardation in over half-a-million consecutive livebirths: an epidemiological study. Am J Metr Defic 89:323-330.

Bradley V, Knoll J, 1995. Shifting paradigms in services to people with disabilities. In: Karan OC, Greenspan $S$ (Eds): Community rehabilitation services for people with disabilities.

Curry CJ, Stevenson RE, Anghton D, Byrme J CareyJC, Cassidy S, CunniffC, Graham JM Jr, Jones MC, Kaback MM, Moeschler J, Schaefer GB, Schwarz S, Tarleton J, OpitzJ. 1997. Evaluation of mental retardation: recommendations of a consensus conference. Am J Med. Genet 72:468-477.

Hagberg B. Kylleman M. 1983. Epidemiology of mental retardation - a Swedish survey Brain Dev 5:441-449.

Jansen DEMC, Krol B, Groothoff JW, Post D. 2004. Eople with intellectual disability and their health problems: a review of comparative studies. I Intel Disabil Res 48:93-102.

King BH, State MW, Shah B, Davanzo P, Dykens E. 1997. Mental retardationi a review of the past 10 years. Part I. J Am Acad Child Adolesc Psychiatry 36:1656-1663.

Kommer G], Stokx LJ, Kramers PGN, Poos MJJC. 1999. Waclitlijstontwikkeling in de zorg voor verstandelijk gehandicapten. Modellering van de woonzorg woot verstandelijk beperkte. RIVM, Bilthoven.

Luckasson R, Coulter DL, Polloway EA, Reiss S, Schalock RL, Snell ME, Spicalnik DM, Stark JA. 1992. Mental retardation: definition, dassification, and systems of supports, $9^{\text {th }}$ ed. AAMR, Washington, DC.

McLaren J, Bryson SE 1987. Review of recent epidemiological studies of mental retardation: prevalence, associated disorders, and etiology. Am J Ment Retard 92:243-254. 
Meijer MM, Carpenter S, Scholte FA. 2004. European manifesto on basic standards of health care for people with intellectual disabilities. Joumal of Policy and Practice in Intellectual orsabilities $1: 10-15$.

Murphy $\mathrm{CC}$, Yeangin-Allsopp $M$, Decoufle P, Drews CD. 1995. The administrative prevalence of mental retardation in 10-year-old children in metropolitan Atlanta, 1985 through 1987. Am J Public Heall $85: 319-323$.

Roeleweld N, Zielluis $\mathrm{GA}$, Gabreëls $\mathrm{F}$. 1997. The prevalence of mental retardation: a critical teview of recent literature. Dev Med Child Neurol 39:125-132.

Schalock RL, Luckasson R. 2004. American Association on Mental Retardation's Definition, Classfication, and System of Supports and its relation to international trends and issues in the field of intellectual disabilities. Journal of Policy and Practice in Intellectual Disabilities 1:136-146.

Schrojenstein Lantman-de Valk HMJ wan, Heurn-Nijsten EWA wan, Wullink M, Dinant GJ, Crebolder HFJM, Metsemakers JFM. 2002. Prevalentieonderzoek: Mensen met een verstandelijke beperking in Nederland. Universiteit Maastricht, Maastricht.

Schrojenstain Lantman-de Valk HMJ van, Metsemakers JFM, Haveman MJ. Crebolder HFJM. 2000 . Health problems in people with intellectual disability in general practice: a comparative study. Family Practice 17:405-407.

Stevenson RE, Schroer RJ 1996. Mental retardation in South Carolina. Characteristics of the study population. Proc Greenwood Genet Center 15:26-31. 


\section{ETIOLOGY OF MENTAL RETARDATION}

The outcome of diagnostic studies on the etiology of mental retardation: Considerations on the classification of the causes 


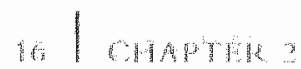




\section{ETIOLOGY OF MENTAL RETARDATION The outcome of diagnostic studies on the etiology of mental retardation: Considerations on the classification of the causes}

Ute Moog

'Department of Clinical Genetics, University Hospital Mastricht, and Research Institute Growth \& Development (GROW), Mastricht Universiry, Maastricht, The Netherlands. 


\section{ABSTRACT}

In the different studies on the etiology of mental retardation (MR), a diagnosis has been reached in a remarkably variable proportion of cases. This is due to differences in methodology (population examined, age of the patients, degree of MR, time and protocol of investigation, expertise), method of classification (according to timing of defect, type of defect or both), and, in particular the different use of the term diagnosis. The latter varies with the employed criteria (causal vs pathomorphological vs pathophysiological), with the degree of exclusiveness (monocausal vs multifactorial/predisposing background factors) and particularly with the degree of implied certainty (definite vs provisional). All these factors contribute to the fact that in general, the results of different clinical studies on the etiology of MR are not strictly comparable and cannot be pooled. A dynamic method of classification is proposed which combines both time of occurrence and type of defect, and includes the degree of certainty of a diagnosis. The method allows identîcation of patients which need follow-up and reconsideration of theirt cases.

Key words: classification of causes; diagnostic yield; etiological studies; mental retardation 


\section{INTRODUCTION}

In the different studies on the etiology of developmental delay (DD) or mental retardation (MR), a diagnosis has been reached in a widely varying proportion of cases. Two examples illustrating the spectrum of outcome are the studies by, on the one hand, Battaglia et al. who "reached a causal/pathogenetic diagnosis in $80.8 \%$ in a cohort of children referred for evaluation of DD/MR" [1999] and, on the other hand, the study performed by Hunter in 2000 who "made a specific genetic/syndrome diagnosis in $19.9 \%$ of cases". The remarkably variable yield of the diagnostic studies on MR has been discussed repeatedly [Anderson et al., 1996; Curry et al., 1997; Stromme \& Hagberg, 2000] and was most often attributed to methodological differences, such as differences in population, time and protocol of investigation. However, as these differences are relatively small between the two cited studies - both being performed in the same period, by experts in the field, and in a cohort of children with DD of variable degree - it is likely that other factors play an important role. Hunter stated that the rate of established diagnoses depends significantly on the definition of a diagnosis [2000]. A comparison of different clinical studies on the etiology of MR performed since 1981 [Hagberg et al., 1981; Fryns et al., 1986; McQueen et al., 1986; Dereymaeker et al., 1988; Lamont et al., 1988; Fryns et al., 1990; Wellesley et al., 1991; Ohdo et al., 1992; Majnemer et al., 1995; Anderson et al., 1996; Root et al., 1996; Saul et al., 1996; Battaglia et al., 1999; Hunter, 2000; Stromme \& Hagberg, 2000; Van Buggenhout et al., 2001; Wilska et al., 2001; Devriendt et al., 2003] shows that apart from methodological aspects in general, different classification systems, and in particular a remarkably differing use of the term diagnosis contribute to the extremely varying results.

In the first section of this paper, the factors influencing the outcome of diagnostic studies on the etiology of MR will be discussed. This is followed by the introduction of an adapted method of classification of the causes of MR which includes the degree of certainty of a diagnosis.

\section{DISCUSSION}

\section{General aspects of methodology}

Clinical studies on the etiology of MR vary with:

- the selection and ascertainment source of cases. Most studies are either community or institution based. The former are mostly based on registration charts whereas the latter are ideally based on a complete and uniform investigation including history, physical examination and laboratory tests. On the 
other hand, institution based studies often investigate a highly selected group of patients, e.g. patients with severe MR [e.g. Fryns et al., 1986]. A review of previous studies, in particular of institutionalized mentally retarded patients was given by Van Buggenhout et a1. [2001] and includes a synopsis of populations and outcomes. Furthermore, there are some studies reporting on a population seen at a specialized diagnostic center or a general genetic clinic; in these studies, the referring specialist plays an important role [Hunter, 20001.

- the age and degree of MR of the patients. It is well known that a younger age increases the likelihood of establishing a specific diagnosis [Curry et all., 1997], in part because of the availability of information about pre-, peri- and postnatal development, medical and family history, and the fact that underlying genetic causes may lead to increased montality at a young age. An IQ roughly $<50$ (moderate, severe and profound $M R$ ) probably also increases the proportion of established diagnoses [Anderson et al. 1996; Raynham et al., $1996 \pi$.

- the time and protocol of investigation. The progress of laboratory and imaging techniques, and clinical syndrome delineation has led to slowly increasing numbers of causal, well established diagnoses. With chronological follow up of patients, this development not only reduces the number of cases with unknown etiology, but it also eliminates previous diagnoses without or with reaching new ones, or confirms previously clinical diagnoses by laboratory test and gives a pathogenetic explanation.

- the expertise of the investigator(s).

Variability in all these aspects contributes to the vast differences in outcome.

\section{Aspects of classification}

The causes of MR can be classified basically according to

1. the type of defect in genetic, environmental and unknown causes,

2. the timing of defect in pre-, peri-, postnatal and unknown causes,

3. the timing and type of defect, thus, a combination of both.

Admittedly, this is an arbitrary academic categorization, and, as will be shown, it is not a sharp categorization. Its purpose is to elucidate underlying classification aspects and their influence on the outcomes.

The first category (classification according to the type of defect) is illustrated by the large South Carolina population study by Anderson et al. [1996] who classified the causes of 7600 persons with MR. In this study the category "genetic causes" is subdivided into chromosomal, single gene, multifactorial, culturofmilial disorders and known syndromes, and the category "environ- 
mental causes" splits into pre-, peri- and postnatally acquired causes. The study thus approaches the third (combined) category.

An example of the second category (classification according to the timing of defect) is the community based Western Australia study by Wellesley et al. [1991] who classified the causes of JDD of 1480 children with an IQ $<70$. As in other studies [Stromme and Hagberg, 2000], prenatal causes are subdivided into genetic, acquired and unknown prenatal causes, thus again approaching the third category. In these and other studies results are subsequently translated into results fitting the second category in order to determine the proportions of genetic and environmental causes. Unfortunately, at this point the flow of data can not be followed. In other terms, in order to distil the proportion of genetic causes of $\mathrm{MR}$, classifications according to timing or type of defect are not per se translatable.

A more sophisticated use of the first category has led to the third one which combines the classifications based on timing and type of defect. A recent example is the classification method delineated by Wilska and Kaski [2001]. The causes of MR are divided into genetic causes, CNS malformations, or syndromes of unknown origin, external prenatal factors, perinatally acquired, postnatally acquired and untraceable/unclassified/unknown disorders. The method takes into account differences between causal genetic diagnoses, as chromosomal or single gene disorders, and pathomorphologically or pathophysiologically descriptive constitutional diagnoses (see below): a CNS malformation might be purely genetic but it might also be caused by teratogenic factors or a disruption. The Belgian studies dating from the late ' 80 s [Fryns et al. 1986; Dereymaekers et al., 1988; Fryns et al., 1990] are yet less elaborated precursors of the same method.

\section{The use of the term diagnosis}

The use of the term diagnosis varies considerably between the studies in question. Firstly, it varies with the employed criteria: the diagnosis may be a causal (e.g., chromosome aberrations, single gene disorders as fragile $X$ syndrome), a pathomorphological (e.g., holoprosencephaly of unknown cause, syndromes of unknown origin) or a pathophysiological diagnosis (e.g., culturofamilial MR). Pathomorphological and pathophysiological diagnoses should be considered as provisional ones, open to reclassification when the underlying cause(s) become(s) known. So far, the different studies classify CNS malformations and/or syndromes of unknown origin differently: as a constitutional disorder |Fryns et al., 1986; Dereymaeker et al., 1988; Fryns et al., 1990], pathogenetic diagnosis [Battaglia et al., 1999] or as a condition of unknown (prenatal) cause lWellesley et al., 1991; Ohdo et al., 1992; Stromme \& Hagberg, 2000]. 
Secondly, the term diagnosis varies in particular with the degree of implied certainty: the diagnosis can be definite or provisional. In general, chromosome aberrations are definite causes of MR but have to be coded as provisional when the meaning is still unclear or subject to further research (e.g., seemingly balanced de novo structural rearrangements, insufficiently delineated deletions found by the use of microarray techniques). Also single gene disorders most often are definite diagnoses but should be open for reconsideration if a strong clinical suspicion cannot be confirmed by molecular testing (e.g., Rett syndrome without MECP2 mutation). The degree of certainty of a diagnosis plays an even more important role with regard to external, particularly to perinatal factors. The majority of studies include perinatal risk factors into the end result of reached diagnoses [Hagberg et al., 1981; Fryns et al., 1986; Dereymaeker et al., 1988; Lamont et al., 1988; Fryns et al., 1990; Wellesley et al., 1991; Majnemer et al., 1995; Anderson et al., 1996; Battaglia et al., 1999; Van Buggenhout et al., 2001; Devriendt et al., 2003]. As perinatal risk factors are highly subjective and often insufficiently documented, in most studies poorly standardized and may arise secondary to an underlying genetic disorder, studies are not strictly comparable in this point. To a certain degree, the same holds true for other external canses (infections).

Thirdly, the term diagnosis varies with the degree of exclusiveness: an identified cause can be the only or at least the predominant cause of MR, but it can also be part of a multifactorial genesis or it may contribute to predisposing background factors. The term "cultural-familial MR" in a diagnostic sense does not only lack causality and clarity, it often describes only some of several factors contributing to MR. "Thus, it should be used with caution and awareness of its limitations. In general, the degree of exclusiveness of an identified or suspected cause is difficult to integrate into any classification method other than by including the category "multifactorial". At this point, a genetic method of classifying the somatic causes of MR has a common surface with broader classifications as handled by the American Association on Mental Retardation [2002].

In summary, methodological factors, different classification methods, and in particular a different use of the term diagnosis contribute to the fact that, in general, results of different clinical studies on the etiology of MR are not strictly comparable and cannot be pooled.

Consequently, summarizing the data of different studies should be avoided. The much appreciated review of several diagnostic studies on MR by Curry et al. [1997], set up to provide guidelines for the evaluation of MR, emphasizes in the discussion the limitations of pooling data ("...it is difficalt, if not impossible, to compare clinical series...") and points to methodological differences and "vastly different classification methods". However, what will be remembered (and often cited) is the suggestion that "a diagnosis/cause of the MR can be identified in 40$60 \%$ of all patients undergoing evaluation'. It is noteworthy that in this study, the 
table presenting the "general distribution by causation" pools causat; pathomorphological and pathophysiological diagnoses as well as defnite and provisional ones.

Despite the present progress in delineating the genetic deteminants of $M R$, it is likely that a group of patients will remain unexplained. Thus, it seems approprate to focus on the qualitative aspects of the evaluation of $\mathrm{MR}$ and to assign more adequately a different diagnosis methodology. The following suggestion of a classification method is meant to contribute to resolving this problem.

\section{Dynamic classification method: a proposal}

The proposed classification method is shown in Table I and basically distinguishes genetic causes, unknown causes including a group of malformative disorders, and acquired causes. In addition, to the diagnoses established as genetic or acquired, a degree of certainty is assigned. Category I (definite) is assigned only in case of a clinically or by laboratory testing definitive diagnosis. In all other cases, the diagnosis belongs to category II (provisional). Provisional means that the security in establishing the diagnosis is more than $50 \%, \mathrm{eg}$, it is more likely that the considered diagnosis is correct than uncorrect. Provisional diagnoses include possible and probable ones with a security of 51 to $79 \%$ and $80 \%$ or more, respectively. Diagnoses proposed with a security of less than $50 \%$ should not be classified as diagnoses. Per definition, cases belonging to "unknown" (2.1-3.5) are categorized as having a provisional diagnosis (II).

Genetic causes (1.1-1.4) are categorised as: chromosomal disorders (1.1), monogenic disorders including nonsyndromic X-linked MR (MRX) (1.2), well-delineated known syndromes (1.3), and multifactorial causes including cultural-familial MR (1.4). The known syndromes group (1.3) is represented by a recognizable pattern of anomalies without established etiology, and by syndromes that can be caused by different pathogenetic mechanisms or in which a monogenic cause has been shown for a part of the patients only. By convention, microdeletion syndromes are also categorized as known syndromes and not as chromosomal. Following the proposed approach, code 1.1 I would be assigned to a patient with a de novo deletion 1 p 36.3, or with a chromosomal imbalance resulting from a familial translocation; code 1.1 . II to an individual with a de novo reciprocal translocation, or a with a submicroscopic terminal deletion $2 q$ and parents unavailable for testing; code 1.2 I to a person with fragile $X$ syndrome proven by FMR 1 analysis, or to a patient with Sanfilippo A syndrome based on biochemical and enzyme analysis; code 1.2 II to a patient with MRX based on the phenotype and family history, or to a person with clinically probable SmithLemli-Opitz syndrome in whom no cholesterol screening could be performed; code 1.3 I to a patient with Angelman syndrome confirmed by molecular analysis, 
or to an individual with a clinically convincing diagnosis of Costello syndrome; code 1.3 II to a patient considered clinically as having probably Rubinstein-Taybi syndrome in whom no CREBBP mutation or chromosomal anomaly could be found, or to a girl with a Ret variant and negative $M E C P 2$ analysis; code 1.4 I to a child with mild developmental delay, nomal phenotype and normall results on testing, born to parents of bordenline intelligence, with further borderline or mildly retarded familymembers; code 1.411 to the same child when adopted with only restricted information on the parents.

It is evident that a growing number of disorders theoretically can be included in group 1.2 or group 1.3, e.g., Cornelia de Lange or Noonan syndromes. Assignment to 1.2 is advisable when the diagnosis has been confirmed by molecular studies or, in general, for a recognizable pattern of anomalies caused by a specific monogenic defect in the majority of the patients. Although arbitrary to a certain degree, the distribution in groups 1.2 and 1.3 is not crucial as both belong to genetic causes and as the classification in definite and provisional diagnoses is more important.

Cases with MR of unknown origin comprise an important subgroup of malformative disorders (2.1-2.3), splitting up into MR with pure CNS malfor mations, e.g., holoprosencephaly of unknown origin (2.1), MR with CNS malfomations and other congenital anomalies (2.2), and MR with congenital anomalies other than CNS malformations and/or dysmorphism (2.3), all of whom do not fit any known syndrome or monogenic disorder. It is strongly recommended that patients with newly described, insufficiently delineated syndromes of unknown origin are included in one of these groups and not in group 1.3.

Groups $3.1-3.5$ are for the unknown cases sensu strictu with unexplained MR without congenital malfomations other than micro- or macrocephaly. This group is subdivided inco: MR only (3.1), MR in association with microcephaly or macrocephaly (3.2), MR in association with neurological symptoms as spastic paresis, seizures, hypotonia dystonia, athetosis or ataxia (3.3), MR in association with psychiatric illness and/or serious behavioral problems $(3.4)$, and a group of cases which cannot be classified or where information is untraceable (3.5). Patients with micro- or macrocephaly and neurological symptoms preferably are assigned to 3.2 (MR + micro-/macrocephaly) unless microcephaly developed over thme secondary to severe neurological problems. If a patient with $\mathrm{MR}$ of unknown origin presents concomitantly with neurological and psychiatric signs, the dominant feature is assigned.

Diagnoses of "acquired MR" $(4.1-4.3)$ are subdivided according to the timing of defect into prenatal (4.1), perinatal (4.2) and postnatal (4.3) acquired causes. In agreement with Wilska and Kaski [2001], the perinatal period comprises one week before till 4 weeks after birth. Code 4.1 I would be assigned to a patient with 
fetal alcohol syndrome (FAS) and known alcohol intake of the mother, or in the case of documented exposition to other teratogenes, or in the case of serologically proven toxoplasmosis; code 4.111 to a child with normal high-resolution banded chromosomes and phenotypically FAS but no (known) alcohol intake of the mother, or to a probable mercury embryopathy; code 4.2 I to a patient with evidence of intrapartum metabolic acidosis, early onset of severe neonatal encephalopathy, later spastic quadriplegic cerebral palsy and anomalies on MRI brain consistent with perinatal distress, or to a patient with kernicterus; code 4.2 II to a patient with cerebral palsy and normal results on investigation whose medical records refer to "severe perinatal problems and asphyxia", or to an individual with cerebral palsy and incompletely documented intracerebral bleeding due to intrapartum injury; code 4.3 I to patients with documented traumatic brain damage, or to an individual with proven lead intoxication; and code $4.3 \mathrm{II}$ to a child with encephalitis after smallpox vaccination by history, or with hypernatremic dehydration at two months of age.

The proposed classification method is a basic approach open to refinement by further splitting of categories for individual users. For practical reasons, splitting of category II (provisional diagnoses) into probable and possible diagnoses can be considered. Splitting of group 3.2 into MR with microcephaly and MR with macrocephaly, or subdivision of other groups may likewise be considered. The achieved diagnostic code can be documented on an individual basis in the patient's charts or, more importantly, in the patient registration database. Databases for specific patient (sub)populations are widely used, and include registrations of institutionalized mentally retarded patients. Addition of the diagnostic code allows ready identification of those patients who have a provisional diagnosis and who thus need follow-up and reconsideration of their cases. The method also facilitates classification of the causes of MR for research and epidemiological purposes, as definite and provisional genetic or acquired diagnoses, pathomorphological, pathophysiological and causal diagnoses, can be distinguished and designated differently.

In conclusion, the method thus serves two major goals: determination of followup and classification with a more transparent use of the term diagnosis.

\section{ACKNOWLEDGEMENTS}

I am very grateful to Bryan Hall for his critical thoughts and helpfull suggestions. 


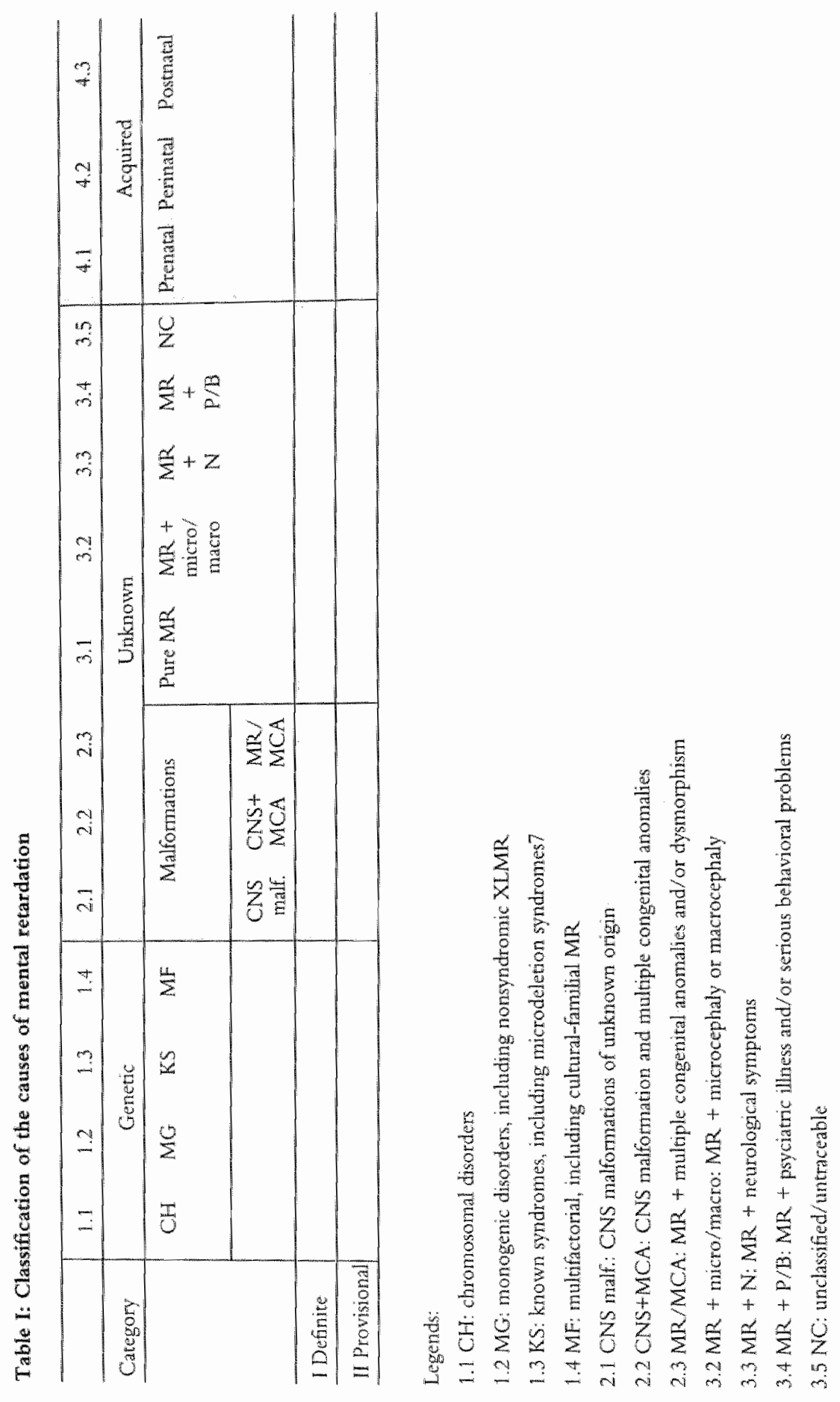




\section{REFERENCES}

American Association on Mental Retardation. 2002. Mental retardation: deffintion, dassification, and sysitems of support, 10th edition. Washington, DC: American Association on Mental Retardation.

Anderson G, Schroer RJ, Stevenson RE. 1996. Mental retardation in Souh Carolina. II. Causation. Proc Greenwood Genet Center 15:32-44.

Battaglia A, Bianchini E, Carey JC. 1999. Diagnostic yield of the comprehensive assessment of developmental delay/mental retardation in an institute of child neuropsychatry. Am d Med Genet 82:60-66.

Curry CJ, Stevenson RE, Aughton D, Byme J, Carey JC, Cassidy S, CumifrC, Graham JMJr, Jones MC, Kaback MM, MoeschlerJ, Schaefer GB, Schwartz S, Tarleton J, OpitzJ. 1997. Evaluation of mental retardation: reconmendations of a consensus conference. Am J Med Genet $72: 468-477$.

Dereymaeker A, Fryns JP, HaegemanJ, Deroover J, wan den Berghe H. 1988. A genetic diagnostic survey in an institutionalized populatin of 158 mentally retarded patients. The Viaene experience. Clin Genet 34:126-134.

Devriendt K, Holvoet M, Fryns JP. 2003. An etiological diagnostic survey in children attending a school for special education. Genet Counsel 14:125.

Fryns JP, Kleczkowska A, Dereymaeker A, Hoefnagels M, Heremans G, Marien J, van den Berghe H. 1986. A genetic-diagnostic survey in an institutionalized populatin of 173 severely mentally retarded patients. Clin Genet 30:315-323.

Fryns JP, Volcke PH, Haspeslagh M, Beusen L, van den Berghe H. 1990. A genetic diagnostic survey in an institutionalized populatin of 262 moderately mentally retarded patients: the Borgerstein experience. J Ment Def Res 34:29-40.

Hagberg B, Hagberg G, Lewerth A, Lindberg U. 1981. Mild mental retardation in Swedish school children. Acta Pediatr Scand 70:445-452.

Hunter AGW. 2000. Outcome of the routine assessment of patients with mental retardation in a genetics clinic. An 」Med Genet $90: 60-68$

Lamont MA, Dennis. NR. 1988. Aetiology of mild mental retardation. Arch Dis Child $63: 1032-1038$.

Majnemer A, Shevell M. 1995. Diagnostic yield of the neurologic assessment of the developmentally delayed child. J Pediar 127:193-199.

McQueen PC, Spence MW, Winsor EJT, Gamer JB, Percin LH. 1986. Cansal origins of major mental handicap in the Canadian martime provinces. Dev Med Child Neurol $28: 697-707$.

Ohdo S, Sonoda T, Ohba K, Hayakawa K. 1992. Etologic and pathogenetic study of mental retardation with multiple congenical anomalies. Acta Paediat Jpix 34:144-150.

Raymam H, Gibbons R, Flint J. Higgs D. 1996. The genetic basis for mental retardation. QIM 89:169-175.

Root S, Viskochil D, Leonard CO, Carey JC. 1996. Generic evaluation of children with developmental delay. Proc Greenwood Genet Center 15:159-160. 
Saul RA, Stevenson RE, Schroer RJ. 1996. Congenital anomalies in individuals with mental retardation. Proc Greenwood Genet Center 15:160.

Stromme P. Hagberg G. 2000. Aetiology in severe and mild mental retardation: a populationbased study of Norwegian children. Dev Med Child Neurol 42:76-86.

Van Buggenhout GJCM, TrommelenJCM, Bruner HG, Hamel BCJ, Fryns J-P. 2001. Clinical etiological survey of a population of 471 mentally retarded patients living in an institution in the Southern part of the Netherlands. Commun Genet 4:109-122.

Wellesley D, Hockey A, Stanley F. 1991. The actiology of intellectual disability in Western Australia: a community-based study. Dev Med Child Neurol 33:963-973.

Wilsk ML, Kaski MK. 2001. Why and how to assess the aetiological diagnosis of children with intellectual disability/mental retardation and other neurodevellopmental disorders: description of the Finnish approach. Eur J Paed Neurol 5:7-13. 


\section{CLINICAL STUDIES}

3.1 Clinical evaluation 30

Appendix A, B, C 37

3.2 Example of syndrome delineation:

Oculocerebrocutaneous syndrome: the brain malformation defines a core phenotype

$J$ Med Genet 2005 May 6 [Epub ahead of print] 47 


\subsection{CLINICAL EVALUATION}

In 1997, the American Consensus Conference has established guidelines for the evaluation of a person with nental retardation (MR) (Curry et al., 1997). Very recently, the NVK (Nederlandse Vereniging voor Kindergeneeskunde, Dutch Association of Pediatrics) has agreed upon an evidence based guideline for the evaluation of children with developmental delay (DD) (to be published in 2005). Based on both and underlyng references, in particular the study by Shevell et al. (2003), as well as the author's own experience, the process of evaluation will be described in this and following chapters. The diagnostic process can be divided into three major parts: assessment of the history, physical examination and diagnostic tests, and in general, follows this order.

Assessment of the history takes into account the pre-and postnatal, medical and developmental history, including the development of behavioral features, as well as a pedigree of the family. The pedigree assessment focuses on the occurrence of $\mathrm{MR}$, congenital malformations, stillbirths and recurrent miscarriages, assesses consanguinity, and ideally encompasses at least three generations. Although time consuming, it is of utmost importance that the history of children with DID, or of adult or elderly persons with MR, is thoroughly assessed together with the parent(s) or with a close family member, and/or a personal care provider who knows the person in question well. In the case of institutionalized mentally retarded persons, it belongs to the tasks of the Physician for Persons with lntellecunl Disabilities (Arts voor Verstandelijk Gehandicapten, AVG) to bring the family and care providers into contact with the clinical geneticist. It can be helpful to give a questionnaire to the family prior to the conversation (Appendix A). Medical daca and results of neuropsychological tests regarding the degree of $M R$. the developmental profile and behavional characteristics, have to be assembled and completed. In the Dutch system, these data are most often registered by the GP (general practicioner), in the charts of the institution or, for children, by the coordinating pediatrician. Additional information deduced from photographs taken in infancy, childhood and adolescence are useful to evaluate the changing phenotype with age. This approach is of particular value for the recognition of syndromes which are better recognizable at a younger age, for estimating the onset of microcephally, and/or to distinguish primary dysmomphism from secondary defomation. When photographs of the family are also available, family resemblance can be taken into consideration.

The physical examination mainly consists of observation, inspection of the body surface, and a basic neurological examination. Contrary to what might be expected by the family, the exammation is not a heavy demand on the patient. 
Although it is advisable to use a documentation form (Appendix B) to facilitate a structured examination, the examination itself has to be flexible, and adapted as far as possible to the individual patient's needs and habits. For example, the time of examination of a person with an outstanding need for regular structures, e.g. autistic disorders, has to follow his/her schedule; and the examination of an individual with a fear of unknown surroundings should preferably take place in a familiar room. The various steps of the examination itsef must be adapted to what the patient admits ("look first at what the patient lets you see"). Apart from the moral and ethical reasons, only a patient-centred procedure allows a realistic impression of his/her behavior, capacities and needs.

Observation aims at a general impression of the personality, of the degree of MR and of the behavior. Of particular interest are posture, movement, walking, mimic, and specific behavioral features such as tics or other stereotypies.

Surface inspection focuses on the recognition of congenital abnomalities and minor anomalies. According to their known or suspected causes, congenital abnormalities are subdivided into three categories (Aase, 1990):

- Malformations. These result from defects of embryogenesis arising during blastogenesis (days 1-28) or organogenesis (days 29-56). If the malformation has little or no effect on nomal life or functioning, it is classified as 'mild', and otherwise as 'severe' or 'major' (Opitz, 1985; Opitz, 2000).

- Disruptions and deformations. These both interfere with normal development, the first by various disnuptive events (e.g. vascular events, infections), and the second by mechanical disturbances.

- Dysplasias: these are produced by abnormal histogenesis.

In contrast to mild or major malformations, minor anomalies are disturbances of phenogenesis, and arise during fetal (days 57-266) or early postnatal life (Opitz, 2000). They differ from common variants by their prevalence: minor anomalies occur in up to $4 \%$ of the general population, and common variants exceed this percentage; together they form the group of 'minor variants' (Aase, 1990). Comprehensive reviews of the extensive discussions of minor congenital anomalies as opposed to mild malformations or normal variants, have been given by Frias \& Carey (1996) and Merks et al. (2003). Merks et al. (2003) classify the phenotypic abnormalities found on physical examination conscientiously into common variants, minor anomalies, malformations, and other congenital abnomalities arising as the result of abnormal morphogenesis or the abnormal function of other structures. The use of the classification list in this paper is recommended for the classification of every phenotypic abnormality. It facilitates the determination of the importance of the abnormality, the pathogenetic mechanism, and in syndrome recognition. Beginning with the work by D.W. Smith, several studies have shown that the presence of multiple minor anomalies increases the risk for a major malformation, may predict an aneuploidy or another constitutional 
disorder, or may be the clue to the recognition of a specific syndrome (Smith, 1971; for reviews see Frias 8 . Carey, 1996, and Merks et al., 2003). The number and nature of minor anomalies therefore has to be documented even when no particular dysmorphism is recognized.

Subjective impressions have to be replaced by objective measurements whenever posstble. Reference tables can be found in the texts of Hall, Froster-Iskenius $\&$. Alanson (1989) and of Gerver (2001). As many parameters are influenced by the ethric background, specific growth charts have been established for different ethnic groups, and these should be used. Of all measurements, head circumference is of particular imporance.

Photographs are taken for documentation of the status, and of changes in phenotype over time when serial examinations are possible. They form the basis of (interdisciplinary) consultations. They should include a front and side view of the face (withoutglasses), an overview with a minimumi of clothing, and photographs of both hands and feet. Documentation of a characteristic behavioral trait requires the recording of a video.

\section{Diagnostic tests include}

- chromosone analysis at a band level of at least 500-550 bands per haploid set in every person, child or adult with unexplained $\mathrm{MR}$.

- most often a DNA test for fragile X syndrome as it should be strongly considered in all males and females with unexplained $M R$.

- further DNA tests when clinical examination gives rise to the suspicion of a particular disorder that can be proven by molecular studies.

- targeted metabolic screening, preferably in combination with ophthalnologic evaluation including fundoscopy.

These issues will be further discussed in chapters $4-6$. The order of testing and whether they are done syn-or metachronously, depend on the clinical presentation. In many situations, a first step of diagnostic tests will include chromosome analysis and fragile $X$ testing, and will proceed to e.g. metabolic testing when the patient shows one or more of the features possibly indicating anetabolic disorder (see chapter 6). It is, however, also possible that a suspicion on clinical grounds directly prompts a particular DN.A test, e.g. for Angelman or Rett syndromes, or metabollic testing.

In agreement with the recommendations of the aforementioned Consensus Conference (Curry et al., 1997), a neurological evaluation, including neuroimaging studies (most often MRI), is indicated when the MR is associated with macro- or microcephaly, epilepsy, loss of acquired skills, or either focal neurological sign. However, diagnostic evaluation of a mentally retarded individual is frequently dictated by considerations of patient care rather than purposes of etiological evaluation. In most cases, MRI studies require transport to a hospital, and 
general anesthesia. In each individual case, these disadvantages have to be balanced against the possible advantages, which are preventive management for the patient, and genetic counselling for family members in the case of an established diagnosis. Associated brain abnomalities have been described for an increasing number of syndromes, and special MR techniques (e.g. proton MR spectroscopy) have proven useful in the determination of inborn errors of metabolism (Battaglia, 2003). Furthermore, the specific genetic defects which lead to CNS malformations are becoming increasingly well known (Sarnat, 2004; Sarnat \& Flores-Samat, 2004). Neuro-imaging studies thus contribute to etiological evaluation and subsequent application of medical guidelines and genetic counselling. However, the likelihood of establishing a diagnosis by neuro-imaging studies has not been established in general, but depends on the particular clinical features.

Evaluation by a variety of other specialists is occasionally indicated; most often, ophthalmological, psychiatric, psychological, and/or dermatologic evaluations are needed.

\section{MULTI-DISCIPLINARY APPROACH}

It is evident that the evaluation of the genetic etiology of MR interfaces to the work of several other specialists, the most important of which are the Physician for Persons with Intellectual Disabilities, pediatrician, (pediatric) neurologist, a metabolic clinical specialist, psychiatrist, psychologist and ophthalmologist. In this, the clinical geneticist often has a central and coordinating role. It is often useful to see the patient in a multidisciplinary setting, e.g. together with the Physician for Persons with Intellectual Disabilities in Institutions for the Mentally Retarded; in a team consisting of a pediatrician, pediatric neurologist, and clinical geneticist for the evaluation and follow-up of children with $\mathrm{DD}$; or together with a psychologist or psychiatrist when behavioral problems or psychiatric illness, are addressed.

With regard to institutionalized patients, a good cooperation with the Physician for Persons with Intellectual Disabilities is of particular importance. It has been proven useful for the Physician for Persons with Intellectual Disabilities and clinical geneticist to agree upon the distribution of their respective tasks. This agreement may look as follows (adapted from Moog \& Dijkstra, 2002):

The Physician for Persons with Intellectual Disabilities has to take an inventory of the population of the institution in order to know who has previously been seen for clinical genetic examination, and when. The admission of a new patient is an excellent moment to check for previous examinations, but a systematic screening of the records will often detect omissions. Often the Physi- 
cian for Parsons with Intellectual Disabilities is the link between the family, care providers, and the clinical geneticist. It is his/her responsibility to propose a genetic investigation, and to explain basically its differentsteps as outlined above, and its benefit (sec chapter 7.1). In preparing the multidisciplinary consultation, the Physician for Persons with Intellectual Disabilities has to check the charts of the patients to be seen, and to prepare a summary of their medical history, and of previous investigations. A specific documentation form facilitates this work (Appendix C). The Physician for Persons with Intellectual Disabilities takes care of possible referrals to other specialists, and communicates the results to the clinical geneticist. Finally, he/she coordinates the change in care and preventive management based on a particular diagnosis (e.g. Healthwatch).

The clinical geneticist has a central role in coordinating the physical examination and laboratory tests. A pragmatic procedure which minimizes traumatic experiences is crucial for the patient. In addition, the clinical geneticist has to assure a good documentation, and for the communication of the results to the family and the Physician for Persons with Intellectual Disabilities.

Thus, the Physician for Persons with Intellectual Disabilities focuses on the preparation of the examination and any subsequent steps resulting from it, whereas the clinical geneticist's work focuses on the physical examination itself, as well as additional laboratory tests. Together, they take into consideration regular followups and revisions of patients with provisional diagnoses, or with $M R$ due to unknown causes.

\section{SIGNIFICANCE OF CLINICAL EXAMINATION}

The above comments on the clinical examination illustrate the importance of a thorough assessment of the history of the patient, and of physical examinations which can involve additional specialists. Syndrome recognition, the need for laboratory tests, and further etiological approaches all depend on the results and conclusions of clinical examinations. An increasing number of genetically determined MR syndromes can be confrmed by cytogenetic or molecular studies. However, primarily the diagnosis is a clinical one. For example, Rett syndrome is based on the history and physical and behavioral findings; Smith-Lemli-Opitz syndrome on the overall phenotype; $4 p$-syndrome in addition on photographs of infancy and childhood; a cryptic familial chromosome aberation on the family history; and LISI related lissencephaly on a MRI scan of the brain.

Solid and well-documented clinical examinations are also essential for develop mental research, to delineate arising genotype-phenotype correlations, and to determine specific genetic defects underlying a clinically known syndrome. Unfortunately, research in this field is often hampered by scarce published clinical 
data. The paper by Judith Hall (2003) gives a summary of the clinical information that should be available.

The article on the brain malformations of patients with a rare $\mathrm{MR} /$ multiple congenital anomalies syndrome (oculocerebrocutaneous syndrome) which follows in chapter 3.2 , illustrates the importance of clinical investigations.

\section{REFERENCES}

Aase JM. 1990. Principles of normal and abnomal development (or/and: the physical examination in dysmorphology). In: Diagnostic dysmorphology. New York and London: Plenum Medical Book Company, pp 5-13 and pp 33-42.

Battaglia A. 2003. Neuroimaging studies in the evaluation of developmental delay/mental retardation. Am J Med Genet 117C:25-30.

Curry CJ, Stevenson RE, Aughton D, Byrne J, Carey JC, Cassidy S, CunniffC, Grahram JM Jr, Jones MC, Kaback MM, Moeschler J, Schaefer GB, Schwartz S, Tarleton J, OpitzJ. 1997. Evaluation of mental retardation: recommendations of a consensus conference. Am J Med Genet 72:468-477.

Frías JL, Carey JC. 1996. Mild errors of morphogenesis. Adv Pediatr 43:27-75.

Gerver WJM, de Bruin R. 2001. Paediatric Morphometrics. Maastricht: Universitaire Pers Maastricht.

Hall J. 2003. A clinician's pea. Nat Genet 33:440-442.

Hall JG, Froster-Iskenius UG, Allanson JE. 1989. Handbook of normal physical measurements. New York: Oxford University Press.

Merks JHM, van Karnebeek CDM, Caron HN, Hennekam RCM. 2003. Phenotypic abnormalities: terminology and classification. Am J Med Genet 123A:211-230.

Moog U, Dijkstra S. 2002. Klinisch genetisch onderzoek: samenwerking tussen AVG en klinisch geneticus. TVAZ 20:5-7.

Opitz JM. 1985. Invited editorial comment: Study of minor anomalies in childhood maligrancy. Eur J Pediatr 144:252-254.

Opitz JM. 2000. Heterogeneity and minor anomalies. Am J Med Genet 91:254-255.

Sarnat HB. 2004. CNS malformations: gene locations of known human mutations. Eur J Pacd Neurol 8:105-108.

Samat HB, Fiores-Sarnat L. 2004. Integrative classification of morphology and molecular genetics in central nervous system malformations. Am J Med Genet 1.26A:386-392.

Shevell M, Ashwal S, Donley D, FlintJ, Gingold M, Hirtz D, Majnemer A, Noetzel M, Sheth RD. 2003. Practice parameter: evaluation of the child with global developmental delay. Neurology 60:367-380.

Smith DW. 1971. Minor malformations: their relevance and significance. In: Hook EB, Janerich DT, Porter IH (eds): Monitoring, birth defects and environment. New York: Academic Press, pp 169-175. 
3 enteren 


\section{Appendix (in Dutch)}
A Questionnaire for parents or other familymembers 38
B Physical examination form 42
C Synopsis of history and previous investigations 45 


\section{APREWDIX A}

\section{Ponsthothe}

Nathen voomaan wan uw kind:

Geboortedatum:

Thensadres:

Teledoon:

Wanner hebt $U$ voor het eerst "iets" opgemerkt bij Uw kind en hoe?

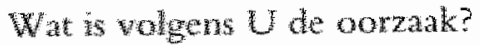

\section{FAlWu}

\section{Motserst}

Wast

Gebouredatur.

Welk anderwistype hebt $\mathcal{U}$ gevolgd?

Wat is Uw beroep?

Aantal vorige zwangerschappen (voor dit kind):

Aantal volgende zwangerschappen (na dit kind):

Aantal miskramen:

Vader

Natm:

Geboortedatum:

Welk onderwijstype hebt U gevolgd?

Wat is Uw beroep? 
Familie (ook overleden familieleden met jaar van overlijden vemelden)

Broers en zussen van de moeder (voornamen en geboortejaar)

Ouders van de moeder (naam tw voomam en geboortejaar)

Broers en zussen van de vader (voomamen en geboortejaar)

Ouders van de vader (nam + voornaam en geboortejaar)

\section{ZWANGERSCHAP}

1. Waren er problemen tijdens de zwangerschap ja/nee/onbekend* Zo ja, welke?

2. Ziekten tijdens de zwangerschap?

ja/nee/onbekend ${ }^{*}$ Zo ja, welke?

3. Nam U medicatie tijdens de zwangerschap?

ja/nee/onbekend ${ }^{\star}$ Zo ja, welke?

4. Had $U$ een Röntgenonderzoek tijdens de zwangerschap? ja/nee/onbekend ${ }^{\star}$

5. Rookte $U$ tijdens de zwangerschap? ja/nee

6. Gebruikte $U$ alcohol tijdens de zwangerschap? ja/nee $e^{*}$ Zo ja, hoeveel glazen per dag? BEVALLING

1. Waren er problemen tijdens de bevalling? ja/nee/onbekend ${ }^{k}$ Zo ja, welke?

2. Duur van de zwangerschap: weken

3. Had U een keizersnede? ja/nee 
4. Hoeveel woog het kind bij de geboorte?

5. Hoe lang was het kind bij de geboorte?

6. Wat was de schedelomtrek van het kind bij de geboorte?

\section{PERIOTE NA DE BEVALLING}

1. Waren er moeilijkheden in de periode na de bevalling? ja/nee/onbekend* Zo ja, welke?

2. Had de baby geelzucht na de bevalling?

3. Was de baby Rhesus-factor negatie?

4. Whe kleur had de baby na de bevalling?

5. Huilde de baby onmiddellijk na de bevalling?

5. Hoeveel dagen lag de baby in de couveuse?

6. Zoog de baby sterk/zwak ?

7. Waren er afwijkingen bij de geboorte?

8. Was langer verblijf in het ziekenhuis nodig? hoelang: warom:

9. Wie was de dokter die Uw kind heeft gevolgd in de eerste levensjaren? Nam en plaats:

\section{ONTWIKKELINGSMIJLPALEN}

Hoe ontwikkelde Uw kind zich op de volgende punten: vroeg, normal, laat of nooit?

Vermeld eventueel de leefijd.

-.- zitten zonder steun leeftijd: ..... vroeg/normal/lat/nooit/onbekend ${ }^{*}$ - kruiper leefrijd: - Lopen zonder hulp leefujd ja/nee/onbekend* ja/nee/onbekend ${ }^{*}$ blauw/wit/rose* direct/niet direct* 
- eerste woordjes leeftijd: .....vroeg/normal/lat/nooit/onbekend (buiten mama-papa)

\section{MEDISCHE GESCHIEDENIS VAN HET KIND VAN GEBOORTE} TOT NU TOE?

1. Is het kind ooit enstig ziek geweest? jalnew Zo ja, waardoor op welke leeftijd(en)

2. Is het kind ooit opgenomen in een ziekenhuis? ja/nee Zo ja, wanneer en wat was de reden?

3. Had het kind ooit stuipen? Zo ja, was dit met of zonder koorts? ja/nee op welke leeftijd? hoe vaak?

4. Had het kind ooit oogproblemen? $\mathrm{ja} / \mathrm{nee}^{*}$ Zo ja, welke?

5. Had het kind ooit neus/keel/oorproblemen?

$\mathrm{ja} / \mathrm{nee}^{*}$ Zo ja, welke?

* doorhalen wat niet van toepassing is 


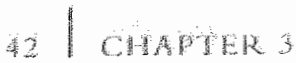

APPENDIX B

Datum: ........ Huize: .......... Arts:

Naam:

Geb.Dat:

VRAAG

Voorgeschiedenis:

Familie:

\section{ALGEMEEN}

Gedrag:

Spraak:

Gehoor:

Nivo:

Visus:

Zindelijk:

Oogheelkundig ond: ja/nee

Medicatie:

\section{NEUROLOGISCH}

Netrologisch onderzoek: ja/nee jaar:

Lopen:

Epilepsie: ja/nee

Type:

Tonus: 


\section{MATEN}

Lengte:

Span:

Gewicht:

Habitus:

Proporties:

SO:

(P...) ICD:

(P...) OCD:

Oren: (P...)

Handen: $\mathbb{R}$ (P...) Dig 3: R (P...)

$\mathrm{L} \ldots . . .(\mathrm{P} \ldots)$

Dig 3: L

Tepelafstand: (P...)

GELAAT

Dysmorfe: ja/nee

Schedelvorm:

Gelaatsyom:

Haargrenzen:

Wenkbrauwen/wimpers:

Ogen:

Oren:

Neus:

Philltrum:

Lippen:

Maxilla:

Manbibula:

Palatum:

Tanden:

Nek:

THORAX/RUG

Scoliose: ja/nee

\section{EXTREMITEITEN}

Handen: . . . . . . . syndactylie: . . . . . . clinodactylie:

handlijnen:

Voeten:

GENITALIA

Menstruatieanamnese:

\section{HUID}

Beharing:

Nagrels: 


\section{INTERNE AFW}

\section{ONDERZOEK}

Chromosonen: ja/nee untslag:

jaar:

te:

DNA naar

$\mathrm{ja} /$ nee uitslag:

jaar:

te:

Metabool: $\quad \mathrm{ja} /$ nee uitslag:

jaar:

te:

CT/MRI-scan: ja/nee uitslag:

jaar:

te:

Röntgen:

SAMENVATTING \& CONCLUSIE

ADVIES \& BELEID 
APPENDIX C

\section{STANDAARDFORMULIER KLINISCHE GENETICA}

Naam:

Geboortedatum:

Instelling:

Specifieke vraagstelling:

Mate verstandelijke handicap:

(indien getest, testuitslag vermelden)

Neurologische problemen:

epilepsie

spasticiteit

mobiliteit

overigen

Psychiatrische problemen/ gedragsproblemen:

Algemene voorgeschiedenis:

(partus, begin retandate, ewt. angeboren afwijkingen, comorbidicit)

Contact familie/klinische genetica:

(familie bij onderzoek aanwezig - familie kont op polikliniek klinische genetica - telefonisch contact met familie opremen - geen familie - anders;

Familie/ curator akkoord?

Zo ja nam en relatie tot client:. 
a 1 CHAWER

Familieanammes:

(m.n. andere personen met MR of ontwikkelingsachterstand)

Eerder genetisch onderzoek:

(chromosomenonderzock en ander onderzoek, datwm en witkomst)

Algemeen diagnostisch onderzoek door neuroloog:

(datum, natrin en uitkomst)

Beeldvorming hersenem:

(datum, soort onderzokek, uttkomse)

Algemeen diagrostisch onderzoek oogarts:

(datwn, naam en witkomst)

Ander onderzoek:

Actuele medicatie:

(dosering riet nodig)

Datum consult:

Gemaakte afspraken: 


\subsection{Oculocerebrocutaneous syndrome: the brain malformation defines a core phenotype}

Ute Moog, Marilyn C. Jones, ${ }^{3}$ Lynne M. Bird, ${ }^{3}$ and William B. Dobyns ${ }^{4}$

'Department of Clinical Genetics, University Hospital Maastricht, and Research Institute Growth \& Development (GROW), Mastricht University, Maastricht, The Netherlands. Dew partment of Dysmorphology and Genetics, Children's Hospital San Diego, San Diego, CA, "Departments of Human Generics, Neurology and Pediatrics, The University of Chicago, Chicago, IL, USA. 


\section{ABSTRACT}

Background: Oculocerebrocutaneous syndrome (OCCS) is characterised by the presence of orbital cysts and anophthalmia or microphthalmia, focal aplastic or hypoplastic skin defects, skin appendages and brain malfomations. The eye and sin abnormalities are well described but the neuropathological features less so. To date, 28 patients with an unequivocal diagnosis of OCCS have been reported, with a preponderance of males.

Objective: To evaluate the brain imaging studies, clinical records, photographs and pathological material of two new and nine previously reported cases of OCCS.

Results: There was a consistent pattern of malfomations in eight of the 11 cases, consisting of frontal predominant polymicrogyria and periventricular nodular heterotopia, enlarged hateral ventricles or hydrocephalus, agenesis of the corpus callosum sometimes associated with interhemispheric cysts, and a novel mid-hindbrain malformation. The latter consisted of a giant and dysplastic tectum, absent cerebellar vermis, small cerebellar hemispheres in most cases, and a large posterior fossa fluid collection.

Conclusions: The mid-hindbrain malformation appears pathognomonic for OCCS. The eye and skin features of OCCS show considerable overlap with several other syndromes, such as encephalocraniocutaneous lipomatosis, oculloauriculo-vertebral spectrum, and focal dermal hypoplasia, none of which has a comparable pattern of brain malformations. In particular the unique midhindbrain malformation also distinguishes OCCS from related syndromes with comparable forebran anomalies. The pattern of malformation described thus helps in differentiating OCCS from other entities. The mid-hindbrain malformation points to a defect of the mid-hindbrain organiser as the underlying pathogenic mechanism.

Keywords: oculocerebrocutaneous syndrome; polymicrogyria; giant tectum;
absent vermis 


\section{INTRODUCTION}

Oculocerebrocutaneous syndrome (OCCS), also known as Delleman syndrome, is a rare multiple congenital anomaly-mental retardation syndrome characterised by the triad of eye, brain and skin malformations, sometimes associated with other features such as craniofacial clefts, skull or rib defects, and urogenital anomalies. We have found reports of 28 patients with unequivocal OCCS, with a preponderance of affected males.[1][2] These reports exclude patients with a possible diagnosis of OCCS or who have features of overlapping syndromes, in particulat encephallocraniocutaneous lipomatosis (ECCL) and oculoauriculovertebral spectrum (OAVS). The cause of OCCS is still unknown.

The eye malformations consist mainly of cystic anophthalmia or microphthalmia and colobomata, while the skin abnormalities consist of skin appendages and focal aplasia or hypoplasia. Both have been well described.[1] Many reports mention cerebral cysts, but this might refer to several different anomalies such as arachnoid, porencephalic or posterior fossa cysts, ventricular enlargement, or any other abnormal fluid collection. Several patients have had agenesis of the corpus callosum. However, many of the reports predate modern brain imaging modalities and even recent reports rarely give a detailed description. A systematic description of the brain malformation in OCCS is not available. We therefore reviewed the brain abnormalities in a series of 11 patients with $\mathrm{OCCS}$, using a variety of brain imaging studies and one necropsy report. While some of the images were old and incomplete, we were still able to document a remarkably consistent pattern of malformations that includes a novel mid-hindbrain malformation.

\section{METHODS}

We obtained all available data on the brain in 11 patients with OCCS, including medical records with reports of brain imaging studies, clinical photographs (Fig. 1), and all or portions of the original brain imaging studies (Fig. $2-3$ and Supplementary Figures). The brain imaging studies included brain magnetic resonance imaging (MRU) in seven patients, cranial computed tomography (CT) in four, and pneumoencephalography (PEG) in one; one patient had both MRI and CT. We also reviewed a necropsy report and limited pathological tissue from the child who had the PEG. 

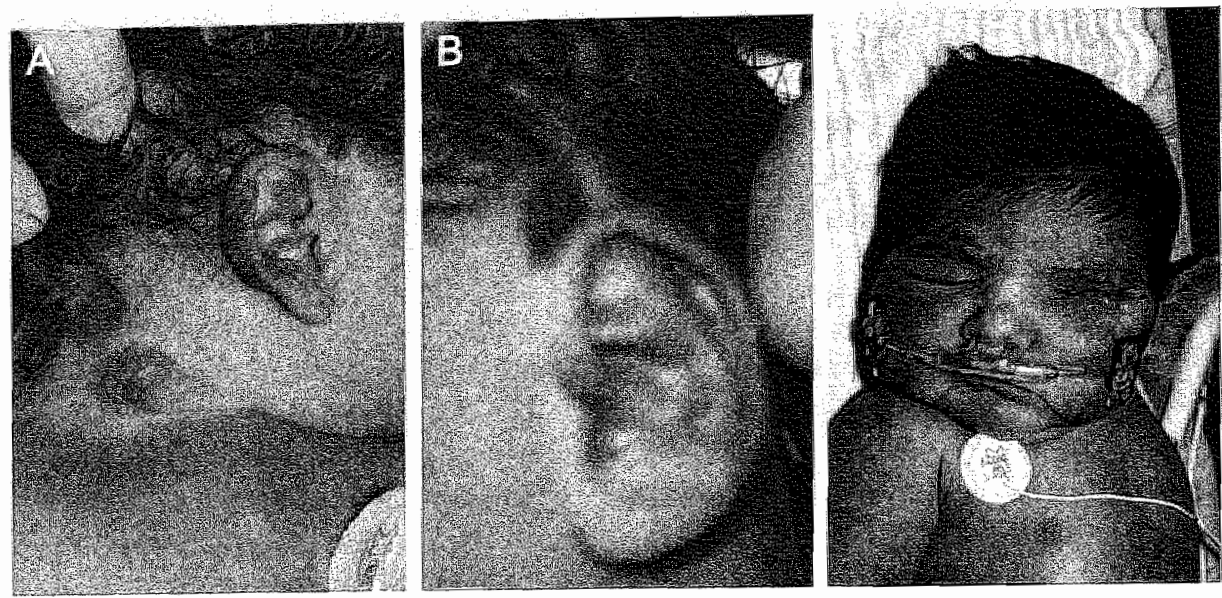

Wigure 1. Chical features of patients 2 and 3 . Note focal aplastic defects above the ears and blister-like lesions in patient 2 (A-B). Patient 3 (C) shows left microphthalmia, and a cleft and mass of tissue with a skiin appendage in the left lower lid near the outer canthus.

\section{RESULTS}

\section{Clinical reports and review of brain abnormalities}

\section{Patient 1}

This boy was born with a large cystic left eye, right microphthalmia, eyelid colobomas and other ocular anomalies, and typical skin appendages. [3] When reevaluated at six years, he had severe mental retardation, intractable epilepsy, severe right hemiparesis, and decreased tactile sensation.

Brain MRI (Fig. 2 and 3A-D) showed severe polymicrogyria (PMG) with very thick cortex in the left frontal, temporal and perisylvian regions, at least one underlying periventricular nodular heterotopia (PNH), enlarged lateral ventricles greater on the left, and agenesis of the corpus callosum (ACC). The midbrain was angled forward, resulting in a nearly horizontal aqueduct that abruptly enlarged into the fourth ventricle about half way down the midbrain. The midbrain tectum was massively enlarged (to around $3 \mathrm{~cm}$ in length), rotated far upwards of the normal position behind the midbrain tegmentum, and indented inferiorly by the enlarging aqueduct into an arched shape. The superior cerebellar peduncles were long, thick and straight, extending almost vertically downward to join the cerebellar hemispheres, which were almost normal in size. The cerebellar vermis was completely absent, although a small and unusual white matter tract connected the two hemispheres. The fourth ventricle was continuous with a large posterior fossa fluid collection, stgggesting cystic enlargement. Similar images from a nomal MRI study are shown for comparison in Supplementary Figure S1. 

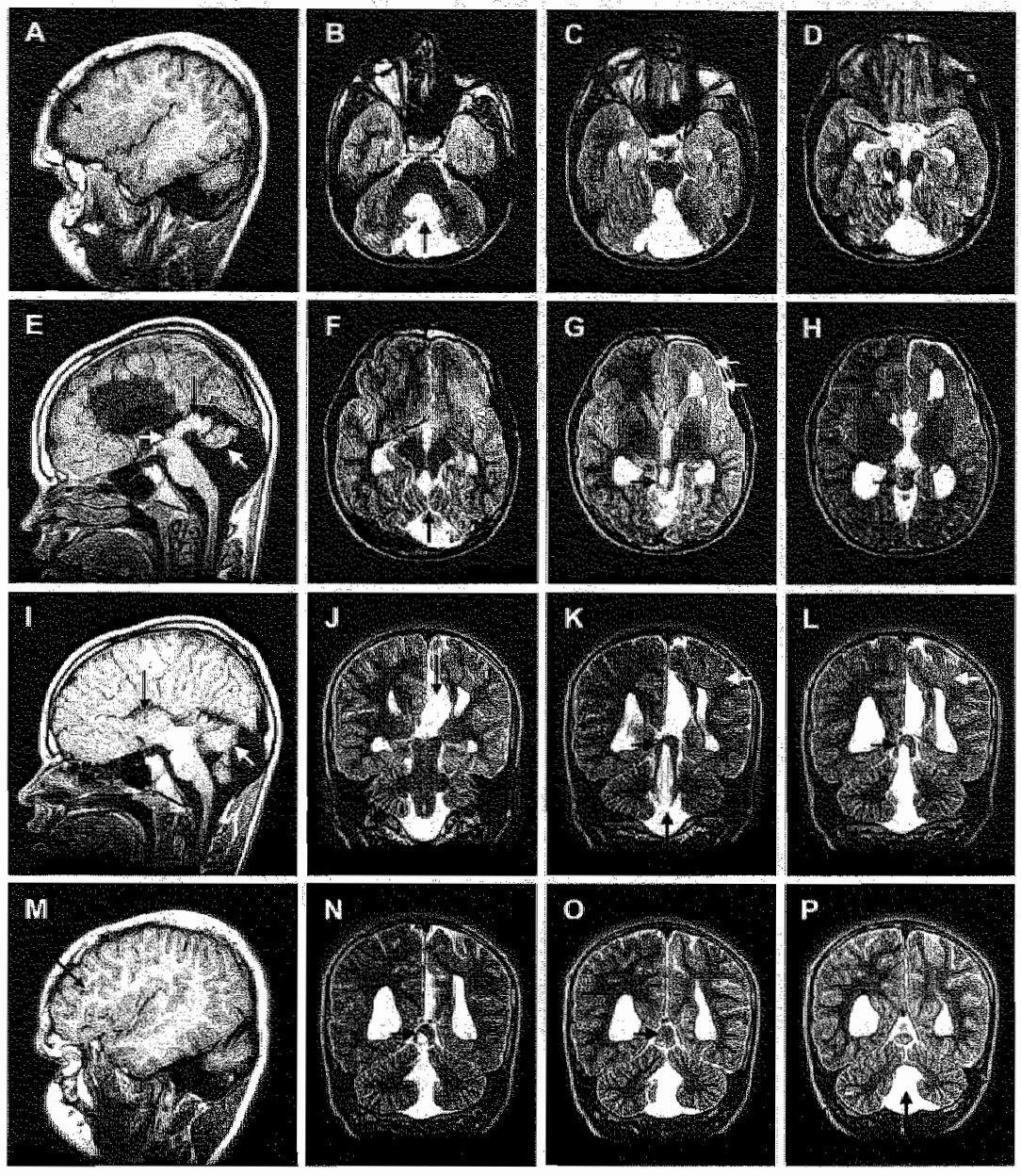

Figure 2. The dassical brain malformation of the oculocerebrocutaneous syndrome (OCCS). Brain MRI fron patient 1 providing details of the $O \mathrm{CCS}$ brain nalfomation. Images through the cerebral hemispheres show an irregular surface, reduced sulcation, thick $10-15 \mathrm{~mm}$ cortex, and reduced white matter typical of polynicrogyra involving the left frontal, temporal and parietal lobes (F-H, J-P and white arrows in $G$, $K$ and $L$ ). The lateral ventricles are mildly enlarged, especially on the left, and the corpus callosum is absent $\left(\mathrm{E}_{\mathrm{s}}, 1\right.$ and J. black arrows in $I$ and J). Images through the posterior fossa show a massively enlarged tectum and absent cerebelhar ventnis. The midbrain regmentum is flexed forward but otherwise nomal. The aqueduct is short and ncarly horizontal (horizontal white arrow in E), and enllarges into the fourth ventricle behind the upper mabrain. The fourth ventricle is contiryuous with a large posterior fossa Auid collection. The midbrain tectum is greatly enlarged (black arrows in $\mathbb{E}, \mathbb{H}$ and $O$ ) and rotated upward, and appears to form an arch over the enlarged aqueduct (black arrows in $G, \mathbb{L}$ and $N$ ). The cerebellar vermis is completely alssent (B-G and L-P, black arrows in $B, F, K$ and $P$ ). The cerebellar hemispheres are nearly normal in size, and seen in the midline because of the missing vermis (white arrow in $\mathrm{E}$ ). The superion cerebellar peduncles are thick and dysplastic, descending vertically from the dysplastic midbrain to the cerebellar hemispheres (horizontal black arrow in $\mathrm{K}$ ). The llower brainsters and spinal cord appear normal. 


\section{Patient 2}

This boy was born to Mexican parents who were second cousins. His birthweight was $3.66 \mathrm{~kg}$, length $51 \mathrm{~cm}$, and head circumference $36 \mathrm{~cm}$. He had bilateral orbital cysts, a cleft left nostril with denuded skin, left macrostomia, multiple skin lesions, and right cryptorchidism. The skin lesions included fleshy mass with tags and pits on the left cheek; tags in the middle of his forehead on top of a hemangioma, on his scalp to the left of the anterior fontanelle, and at the tip of the coccyx; a focal aplastic defect above the right and a crescent shaped one above the left ear (Fig. 1A-B), another focal aplastic skin lesion just below the xyphoid process, and three deflated blister-like lesions on the right neck (Fig. 1A). The left orbital cyst enlarged and was removed. Pathological examination showed malformed retinal and glial tissue with dystrophic calcifications. The mass on the cheek was also removed together with a maxillary exostosis beneath it. Pathological examination confirmed a hamartoma. Atone year, he had seizures and developmental delay.

Brain MRI at eight months (Fig. 3E-H) showed asymmetric PMG involving the frontal and perisylvian region, several PNH along the anterior body of the left lateral ventricle, mildly enlarged ventricles, and ACC. The PMG, PNH and ventricular enlargement were all more severe on the left. The upper midbrain was angled forward, resulting in a nearly horizontal aqueduct. The aqueduct was short, and abruptly enlarged into an extra ventricle just above the fourth ventricle. The tectum was again massively enlarged (to around $4 \mathrm{~cm}$ in length), rotated upward and curved, providing the roof of the extra ventricle. The cerebellar vermis was absent and the hemispheres were probably small from the limited irmages available. The fourth ventricle communicated with a large posterior fossa fluid collection.

\section{Patient 3}

This girl was bon to a 33 year old Hispanic woman and her 32 year old unrelated husband. Her birth weight was $3.77 \mathrm{~kg}$, length $50 \mathrm{~cm}$, and head circumference 35 cm. She had multiple anomalies including left microphthalmia, a disorganised mass of tissue with a skin appendage and cleft in the lefulower lid near the outer cantlus (Fig. 1C), and multiple skin lesions consisting of tags in the left nares, the periumbilical region, the right groin and posterior to the anus; punched out aplastic defects in the left scalp and right heel, and multiple circumscribed hypoplastic defects with depression of subcutaneous tissue and lack of hair over the left leg. On pathological examination, the swelling near the left eye was a benign hamartoma with $46, \mathrm{XX}$ chromosome constitution, while the hypoplastic skin defects were neuroectodermal developmental dysplasias. An omphalomesenteric duct remnant was found in the umbilical cord. Her heart was structurally nomal but displaced in the chest by an anterior diaphragmatic eventration 

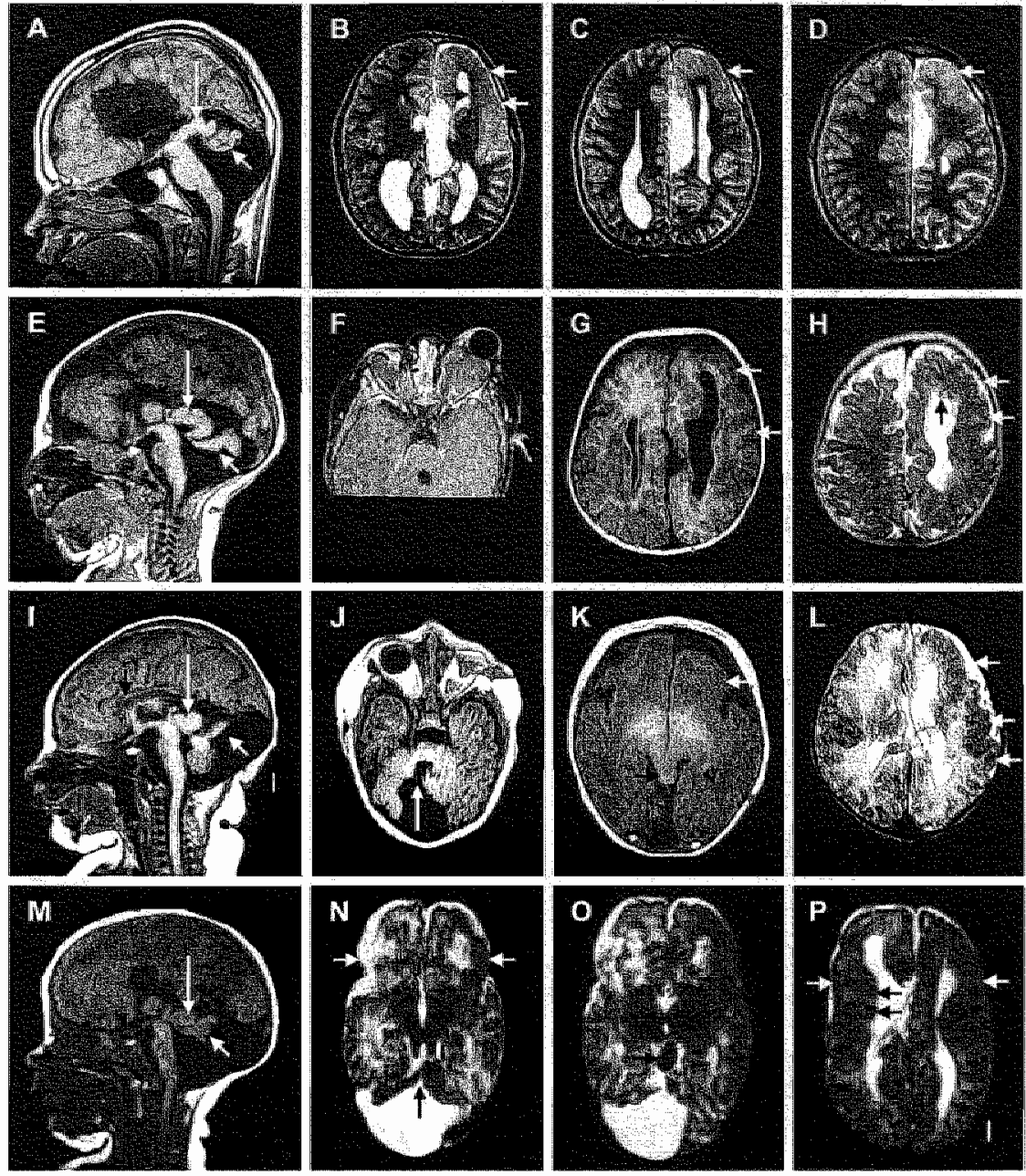

Figure 3. The classical brain malformation of the oculocerebrocutaneous syndrome (OCCS). MRI from patients 1 to 4 also demonstrate the typical OCCS brain malformation. Views of the cortex show polymicrogyna (horizontal white arrows in B-D, G-H, K-L and N-P), which is asymmetric in all tour patients with more severe changes on the left (the right side of the images) in patients 1-3 (A-L) and on the right in patient \& (M-P). Several periventricular nodular heterotopia are seen adjacent to the frontal homs and anterior bodies of the lateral ventricles (black arrows inside the ventricles in $B, H$ and $P$ ). The white matter is poorly myclinated in patients 2-4 (E-P) (patient 1 is older). The corpus callosum is absemt in patients 1,2 and 4 (A, E and $M$ ), and dysplastic in parient 3 (black arrow in D). Images through the posterior fossa show a massively enlarged and upwardly rotated tectum (long white arrows in $A_{n} \mathbb{E}, 1$, and $M$ ) and absert vermis (vertical arrows in $J$ and $N$ ) in all four patients. In all, the midbrain is angled more forward than normal leading to a short, horizontal aqueduct, enlarging premarurely into the fourth ventricle $(A, I, M)$ or appeaning to form an abnomal extra ventricle behind the midbrain (E); the fourth ventricle is continuous with a lange posterior fossa fluid collection. The cerebellar hemispheres are small and have a dysplastic foliar pattern in patients 3 and $4(0$ and $N$ ), and are seen in the midline because of the absent vermis (short white arrows in $A, E . I$ and $M$ ). 

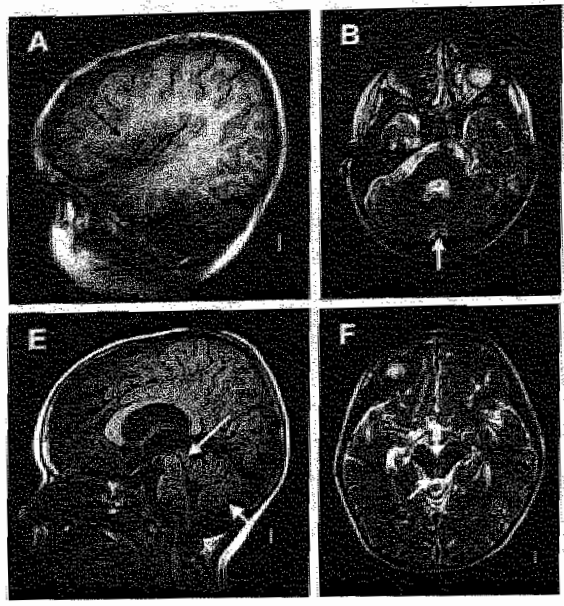
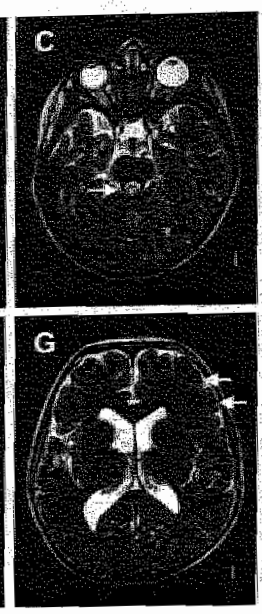
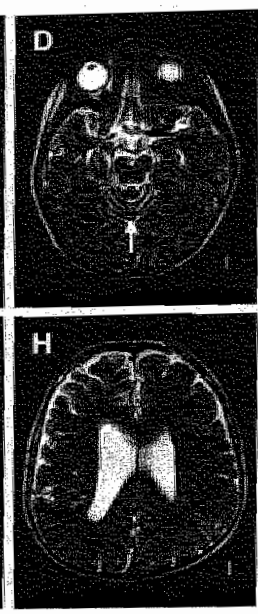

Figure $\$ 1$. Nomal brain MRI inages comparable to Figures $2 \mathrm{~A}+\mathrm{H}$ demonstrate a nomal Sylvian fissure (arrow in $A$ ), normal cerebellar vermis (arrows in $B$ and $D$, and bottom arrow in E), normal superior cerebellar peduncles (arow in C), normal midbrain tectume (top arrow in $\mathrm{E}$ and arrow in $\mathrm{F}$ ), and normal cortex (arrows in $G$ )

that was repaired. A few new skin lesions were seen during the first year, but not thereafter. Serial neurological examinations showed dysarthria, hypotonia and a mild right hemiparesis. Cognitive functioning at three years was nomal. An electroencephalogram was normal. Otoacoustic emission and sound field testing documented normal hearing bilaterally.

Brain MRI at one day (Fig. 3I-L) showed asymmetric PMG in the left frontal and perisylvian regions, possible PMG in the right frontal lobe, and mildly enlarged left lateral ventricle. No heterotopia were seen but the resolution was low. The corpus callosum was dysmorphic with a thin body and absent splenium. The midbrain was angled slightly forward and the lower aqueduct was mildly enlarged. The midbrain tectum was enlarged (to around $1.5-2 \mathrm{~cm}$ ) but not rotated upward. The cerebellar vermis was absent and both hemispheres small, especially the left. The fourth ventricle was large and communicated with a large posterior fossa fluid collection.

\section{Pattient 4}

This boy was blind because of bilateral cystic anophthalmia, and had typical skin appendages. His case has been published in detail previously. [1] [4] At eight years, he had severe mental retardation and epilepsy.

Brain MRI (Fig. 3M-P) showed frontal PMG extending to the perisylvian, parictal and temporal regions, PNH along both frontal horns and lateral bodies of the lateral ventricles, mildly enlarged lateral ventricles, and complete ACC. The 
cortical malformation was more severe on the right. The midbrain was anteverted resulting in a nearly horizontal orientation of the aqueduct, which was mildy enlarged in its inferior portion. The tectum was moderately enlarged $(1.5-2 \mathrm{~cm})$ and round. The cerebellar vermis was absent and the hemispheres both very small. The fourth ventricle was continuous with a large posterior fossa fluid collection.

\section{Patient 5}

This boy had left cystic microphthalmia and eyelid coloboma, and typical skin lesions of OCCS. [1] [4] At 26 months, he had moderate mental retardation and epilepsy.

Brain MRI (Fig. S2C-D) at seven months and later CT (Fig. S2E-H) showed frontal PMG extending an uncertain distance posteriorly, more severe on the right. The lateral ventricles were enlarged, left more than right and separated by several interhemispheric cysts posterior to the third ventricle - some with increased signal indicating lack of communication with the ventricles-suggesting total ACC. Lower images showed an enlarged tectum with prominent and probably horizontal aqueduct, absent cerebellar vermis, moderate hypoplasia of the right and severe hypoplasia of the left cerebellar hemispheres, and a large posterior fossa fluid collection.

\section{Patient 6}

This boy was one of the original patients from the first report by Delleman et al., and was reported again at age 17 years. [5][6][7] He presented with right cystic microphthalmia, bilateral eyelid coloboma, bilateral focal hypoplastic skin defects including a typical crescent-shaped defect behind the ear, and skin appendages. He also had severe mental retardation.

Cranial CT (Fig. S2I-L) done at ages four and seven years showed a thick and irregular cortex typical of PMG; this was present diffusely and was most severe in the smaller right frontal lobe. The lateral ventricles were asymmetrically enlarged with the right much larger than left, and separated by a midline cyst that appeared to be an extension of the third ventricle. The latter suggests partial ACC. The midbrain was dysplastic with an enlarged aqueduct on one image and an unusual round mass of tissue on the highest image. The pons appeared mildly small, the vermis absent, and the cerebellar hemispheres small especially on the right. A large fluid collection was located just behind the cerebellum that probably communicated with a low occipital skull defect, consistent with a meningocele.

\section{Patient 7}

This boy was patient 2 in the original paper reporting OCCS. [5] [6] He had bilateral cystic microphthalmia and eyelid colobomas, typical skin lesions, severe 

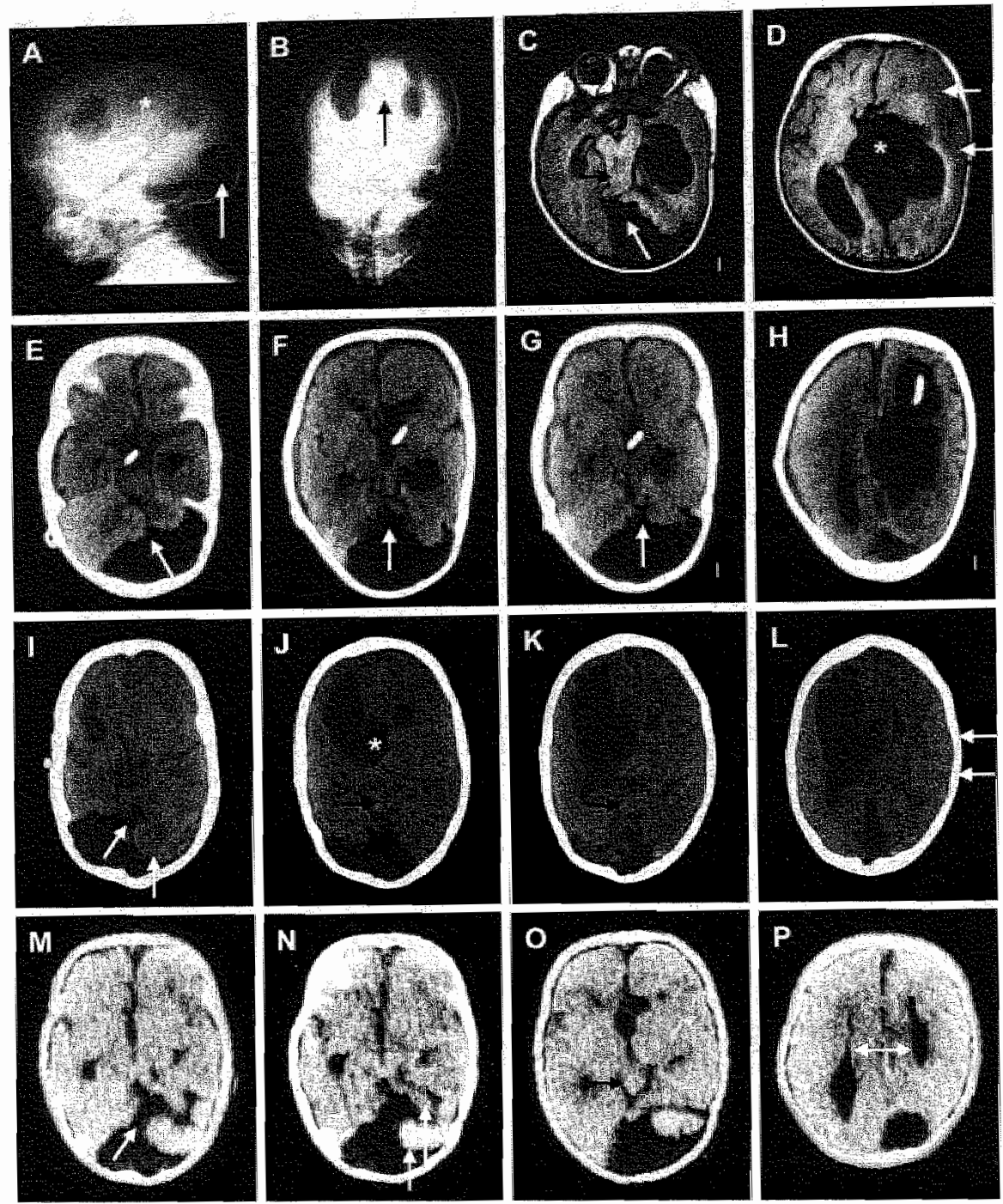

Figure S2. The classical OCCS brain malformation. Lower resoltution brain umaging studies in four other patients showed similar changes. These consisted of a pneumoencephalogram in patient 8 (A-B), two images from an MRT in patient $5(\mathrm{C}-\mathrm{D})$, and cranial CT scans in patients $5(\mathrm{E}-\mathrm{H}), 6$ (1-L) and 7 (M-P). Inages through the cerebral hemispheres in patients 5 and 6 show loss of the normal gyral patterm and moderately thick cortex (white arrows in D and L) that probably represent polytutcrogyria. The resolution is too low to assess the cortex in patient 7 (M-P). The lateral ventricles are mildly enlarged and widely separated in all four parients (asterisk in $A_{\text {a }}$ arrows in $B$ and $P$; also scen in F-H and $\mathrm{J}-\mathrm{L}$ ) indicating agenesis of the corpus callosum, with large interhemispheric cysts in pathents 5 and 6 (asterisks in D and $\mathrm{J}$ ). Inages through the posterior fossa in patients 5-7 show arge and dysplastic midbrain tectun (black arrows in $\mathrm{C}, \mathrm{J}-\mathrm{K}$ and $\mathrm{O}$ ), absent vermis (angled arrows in $C, E, I, M$ and vertich arrows in $F-G$ ), and small, asymmetric cerebellar hemispheres ( $C$, $\mathbb{E}-G,[-K, M-O$ with vertical arrows in $[$ and $N)$. All fou patients have large posterior fossa fluid collections (A-I and L). 
mental retardation and a seizure disorder. He died at two years from complications of hydrocephatus.

Only a low resolution CT (Fig. S2M-P) from 1977 was avalable for review, and the gyral pattern was too indistinct to assess. The lateral ventricles were mildy enlarged, more on the right, and widely separated, suggesting complete ACC. The tectum was large and dysplastic, the vermis absent, and the cerebellar hemispheres were hypoplastic, the right side being more severely affected. The midbrain appeared to connect to the cerebellar hemispheres directly. Serial scans were reported to show progressive hydrocephalus.

\section{Patient 8}

This Geman boy presented in the neonatal period with bilateral cystic anophthalmia, skin appendages in the periorbital region and on his trunk and the scalp, and numerous focal skin defects. He died at age one year. [7]

PEG done years ago (Fig. S2A-B) showed asymmetrical, enlarged, and widely separated lateral ventricles typical of $A C C$, probable hydrocephalus, a large poste-rior fossa fluid collection, and a skull defect in the occipital midline suggesting a meningocele. Necropsy showed PMG, hydrocephalus, an interhemispheric cyst and a malformation of the midbrain tectum, which was $5 \mathrm{~cm}$ in length and extended beyond the cerebellum. We were able to obtain a single block of tissue from the cortex, most probably from the occipital lobe, which confimed a severe cortical dysplasia, although preservation was too poor to classify the type. Several intrabdominal neurofibromas were found along the sympathetic chain.

\section{Patient 9}

This three yeam old Belgian boy had eyelid and iris colobomas but no other eye anomalies, and atypical skin abnomalities consisting of small periorbital nodules, a small skin appendage on the thumb and linear skin defects on the trunk and arms. [8]

A suboptimal and incomplete MRI (Fig. $\$ 3 \mathrm{~A}-\mathrm{B}$ ) showed a normal or possibly mildy dysplastic gyral pattern, enlarged and asymmetric lateral ventricles, larger on the left, and partial $\mathrm{ACC}$ with a small frontal remant near the genu. Several loculated cysts with high signal (protein content) were seen within the lateral wentricles. The brainstem and cerebellum appeared grossly nomal.

\section{Patient 10}

This Dutch boy had unilateral cystic microphthalmia, characteristic skin lesions and mild mental retardation. He was also reported previous]y. $[9]$

"The report of his MRI noted enlarged ventricles, but none of these images were available for rewiew. A single midsagittal MRI (Fig. S3C) showed a nomal gyal pattern along the medial surface and total ACC. The pons appeared moderately 

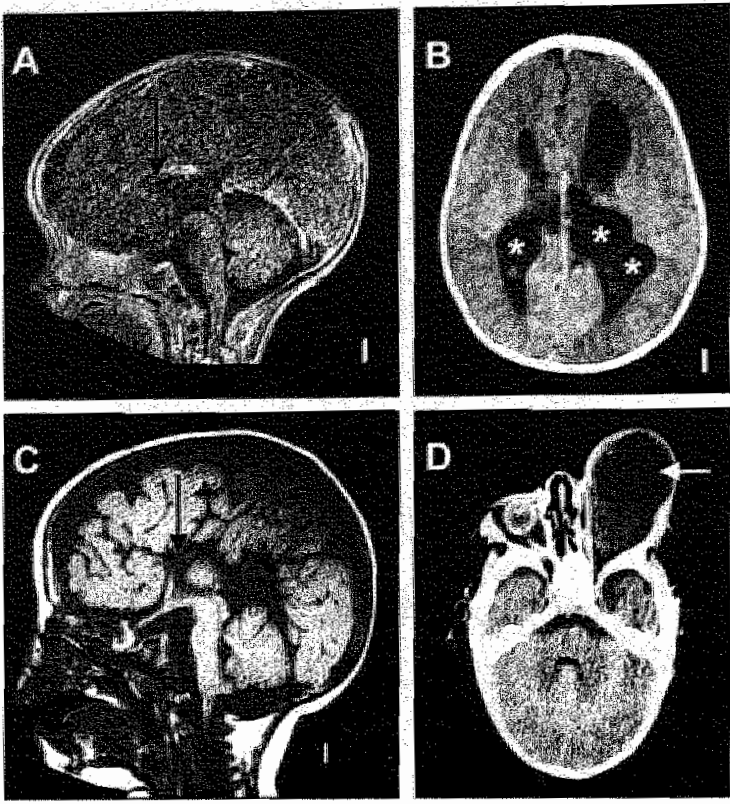

Figure $\$ 3$ Incomplete $0 \mathrm{CCS}$ brain malformation. In contrast, brain imaging studies in three OCCS patients were also suboptimal and ncompllete, but showed less severe malformations. These consisted of an old $M R I$ in parient $9(A-B)$, a single MRI mid-sagital image in parient 10 (C), and a few CT images through the posterior fossa (D) in patient 11. The gyral pattern appears nomal on limited views in patients 9 and $10(B$ and $C$ ). The lateral ventricles are muildly enlarged and separated with several intraventricular cysts in patient 9 (asterisks in B), but cannot be assesped in patients 10 or 11 . The corpus callosum is absent save for a small anterior remmant in patient 9 and completely absent in patient 10 (black arrows in $A$ and $C$ ). The brainstem including the tectum, and the cerebellun appear nomal in all three patients $(A, C$ and $D)$. The left eye is cystically endarged in patient 11 (D).

narrow or flat, but the midbrain including the aqueduct and tectum, and cerebellar vermis appeared normal.

\section{Patient 11}

This Russian baby was born with a huge anophthalmic orbital cyst on the left, which had already been diagnosed prenatally by ultrasound. He had typical skin lesions located on the left side or the midline. In addition, he had bilateral cryptorchidism and mild anomalies of the ribs. Apart from mild hypotonia, his psychomotor development was reported to be nomal at two years. His case has been published in abstract. $[10]$ In addition, clinical data and photographs were avaliable.

Crmal CT scan was reported as normal except for the eye. A single suboptimal image was avalable for review (Fig. S3D). It showed a mildly enlarged space anterior to the left temporal pole, normal bain stem and cerebellum, and left cystic anophthalmia. 


\section{DISCUSSION}

OCCS is a rare malformation syndrome that hitherto has been diagnosed on the basis of the typical eye and skin abnomalities. We reviewed the brain abnomalities of 11 patients with OCCS which are summarised in Table 1 . Owing to the rarity of OCCS, we included patients ascertained over many years and as a result, many of the available brain imaging studies were suboptimal and incomplete. We were able to review five patients in detail (patients 1 to 5), one adequately (patient 6), and five to a limited extent (patients 7 to 1.1). Despite this, we were able to document a remarkably consistent malfomation in eight of the 11 patients and unexpectedly found a novel mid-hindbrain malformation. The three remaining patients had similar but less severe forebrain abnormalities, but lacked the midhindbrain malfomation, which we suspect to be pathognomonic for OCCS.

\section{Typical OCCS brain malformation}

In the eight patients with the most typical malformation complex, the forebrain malformation consisted of: frontal predominant PMG; PNH always located beneath the PMG; complete or partial ACC, sometines associated with interhemispheric cysts; and enlarged third and lateral ventricles complicated by hydrocephalus in four patients.

The novel mid-hindbrain malformation was found in all eight patients, and consisted of a giant tectum, absent vermis and large posterior fossa fluid collection. The midbrain tegmentum was flexed forward, making the aqueduct nearly horizontal in four of the five patients with complete MRI studies. The giant and dysplastic tectum was rotated upward well above the nomal position, and appeared to form an arch over the enlarged lower aqueduct in several patients. The cerebellar hemispheres were missing or hypoplastic with a dysplastic folar pattern in seven of eight patients. The fourth ventricle communicated widely with a large posterior fossa fluid collection, sometimes associated with an occipital meningocele. These anomalies, excluding the midline malformations, were asymmetric in all eight patients. The more severe PMG, more numerous PNH, larger lateral ventricles, and smaller cerebellar hemispheres were always on the same side when we could assess this.

The key forebrain malfomations of PMG, PNH, enlarged ventricles, and ACC are relatively common individually, but occur together in only a few syndromes, as we will review. Thus this pattern should be very helpful for diagnosis. The nidhindbrain malformation has previously been confused with typical DandyWalker malformation (DWM), which should not be surprising. The usual diagnostic criteria for DWM include hypoplasia of the cerebellar vermis and widely open fourth ventricular outflow tract communicating with a large posterior fossa 


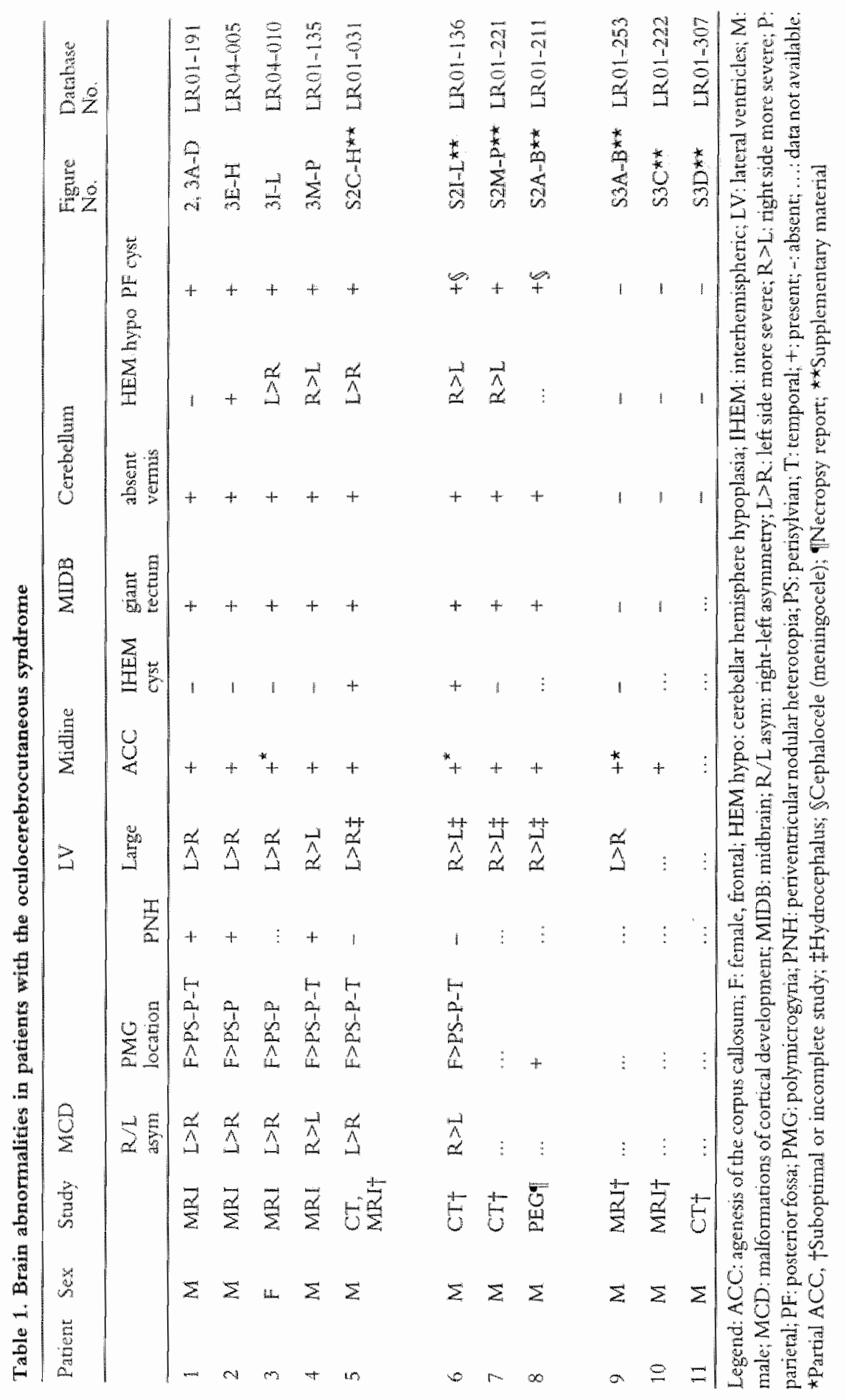


fluid collection, or so called cystic enlargement of the fourth ventricle. [11][12] While the typical OCCS mid-hindbrain malformation described here includes each of these criteria and so could be labelled as DWM, we think this would lead to diagnostic confusion. The OCCS mid-hindbrain malformation includes many other anomalles and is clearly much more severe and complex than DWM. Despite considerable experience in evaluating brain malformations in many different disorders, we have not seen this mid-hindbrain malformation in any other context. We hypothesise that all or most patients with the giant tectumabsent vermis malformation have OCCS, and that most but not all patients with OCCS have the mid-hindbrain malformation.

\section{Incomplete OCCS brain malformations}

Only suboptimal imaging studies were available for the remaining three OCCS patients, but at least two had ACC and none had the mid-hindbrain malformation. The gyral pattern and cortex were either normal or mildly dysplastic in patient 9 , but resolution of the MRI was too low to be sure. This could not be assessed in the other two patients. Patient 9 also had mildly enlarged lateral ventricles with several cysts within them that appeared quite different from the midline cysts seen in two patients from the more typical OCCS group. Two of the three (Nos 10 and 11) had typical eye and skin changes of OCCS, although patient 10 was less severely affected than any of the others. In contrast, patient 9 had atypical linear skin defects with unusual localisation. However, one patient with less typical eye and skin lesions was also found in the group with the typical brain phenotype. We do not yet have enough evidence to determine whether OCCS in these three patients results from the same cause as OCCS in more typical patients.

\section{The differential diagnosis of OCCS}

Our results have implications for the differential diagnosis of several related syndromes. Some have overlapping eye and skin changes such as ECCL, OAVS, and focal dermal hypoplasia (FDH or Goltz syndrome). Others have similar brain malformations, especially Aicardi syndrome and a recently recognised group of syndromes with PNH and PMG.

ECCL and OAVS have considerable overlap with OCCS with regard to the skin, eye and other associated abnomalities. Extensive lipomatosis of the brain and spinal cord are characteristic of ECCL.[13] In addition, asymmetries of the cerebral hemispheres, an abnormal gyral pattern, cortical calcifications, porencephalic or arachnoid cysts and dilated lateral ventricles have been described repeatedly.[14][15][16][17] However, mid-hindbrain malformation has never been 
described in ECCL. In OAVS, only a minority of the patients have developmental delay. A few have hydrocephalus or various brain malformations, but no pattern has emerged except that patients with microphthalmia, clefts or other evidence of a severe phenotype are more likely to have developmental problems. [18] Several patients with (possible) OCCS and overlap with OAVS have been reported.[19][20][21][22] One boy had PMG over the frontal lobes, ACC and a midline cyst and so probably had OCCS.[20] Several other patients with overlapping features of OAVS and OCCS have had massive hydrocephalus without the brain anomalies characteristic of OCCS. In this group, the combination of severe bydrocephalus with anophthalmia or severe microphthalmia and clefts favours OAVS.

FDH is $\mathrm{X}$-linked disorder mainly affecting females characterised by a combination of cutaneous, ocular, neurological, and skeletal features.[23] Focal hypoplastic skin lesions, often with herniation of fatry tissue, and linear pigmentation are the predominant cutaneous features. In contrast to OCCS, the skin lesions commonly follow the lines of Blaschko, indicating a mosaic defect. Skin tags are papillomas, in contrast to the (mostly periorbital) hamartomatous tags in OCCS. Ocular features are very diverse and mostly affect the anterior chamber; chorioretinal and iris colobomas are reported but orbital cysts have not been described. Skeletal defects of the hands and feet may occur. X-rays show striation of the bones in most patients. Whereas many patients are mentally retarded, brain malformations have rarely been described and do not correspond to the brain malformations seen in OCCS.

\section{Aicardi symdrome}

The typical OCCS brain malformation overlaps substantially with the brain malformation seen in Aicardi syndrome, which is thought to be $\mathrm{X}$-linked with embryonic lethality in males. Although the typical eye anomalies (chorioretinal lacunae) are different and the skin generally is nomal, other features of Aicardi syndrome overlap considerably with OCCS. For example, the brain malformations in Aicardi syndrome include PMG, rare PNH, enlarged ventricles (but not typically liydrocephalus), and ACC. [24][25] Interestingly, a few patients with Aicardi syndrome had DWM.[26] Other overlapping features include microphthalmia, coloboma of the optic nerve, scalp lipoma, cleft lip/palate and costovertebral defects.

\section{PNH-PMG syndromes}

We have recently delineated several syndromes with PMG, PNH, and other anomalies (Dobyns WB, unpublished data). The frontal-perisylvian subtype consists of PNH lining the lateral body and frontal horns of the lateral ventricles, overlying PMG that is most severe in the perisylvian area, and sometimes ACC 
and mild cerebellar vermis hypoplasia. The malformation is usually symmetrical, and no other anomalies have been observed. A posterior subtype consists of PNH of the temporal horns, trigones and occipital horns of the lateral ventricles, overlying $P M G$ most severe in the temporal, parietal and occipital lobes, and frequent $A C C$ and hypoplasia of the entire cerebellum. This malformation complex is usually asymmetrical, but again no other anomalies have been found; in particular the mid-hindbrain malformation described in this paper has not been present.

\section{Pathogenesis of OCCS}

Analysis of available data regarding the pathogenesis of OCCS provides two important clues, both of which support a genetic etiology for OCCS despite the lack of familial recurrence. First, a striking preponderance of males has been reported, including 10 of the 11 patients reported here. The only female in our series had the typical brain malformation, which suggests that she has the same syndrome. Among the six other female patients reported, one did not undergo brain imaging, [6] one had a normal cranial $\mathrm{CT},[27]$ and four had malformations that may fit the classical brain phenotype. [28][29][30][31] These data suggest that OCCS may be X-linked.

Second, the unusual mid-hindbrain malformation suggests an abnormality of the isthmus organiser, which is located between the embryonic midbrain and the first segment of the hindbrain (rhombomere 1 or Rh1) and controls development of the midbrain, upper pons and cerebellum. Recent experimental data in the mouse show that two transcription factors (the rostrally expressed Ot. 2 gene and caudally expressed $G b \times 2$ gene) repress each others' expression, forming a sharp boundary between the midbrain and Rh1. This establishes the position of the developmental signaling center for this region and ultimately defines the posterior limit of the midbrain and the anterior limit of the cerebellum. [32]|33][34] One possible interpretation of the giant tectum-absent vermis malformation in OCCS is that the boundary between the midbrain and hindbrain has been shifted caudally in the dorsal portion of the embryonic neural tube, which is less extensive than observed in $G b \times 2$ knockout mice and so appears provisionally unique.

\section{CONCLUSION}

The reported pattern of brain malformations in patients with OCCS extends the phenotype and should prove very useful in establishing the diagnosis and differentiating it from other entities, in particular from syndromes with overlapping skin and eye features. These observations should contribute to unravelling the underlying pathogenic mechanism. The novel mid-hindbrain malformation 
points to a defect in early pattern formation at the stage when the isthmus organising center is established, setting wp the boundary of the midbrain and cerebellum.

\section{ACKNOWLEDGEMENTS}

We thank Jeffrey Golden, University of Pennsylvania School of Medicine and the Children's Hospital of Philadelpha, for pathological review in patient 8.

\section{REFERENCES}

1. Moog U, de Die-Smulders C, Systermans JMJ, Cobben JM. Oculocerebrocutaneous syndrome: report of three additional cases and aetiological considerations. Clin Genet $1997.52: 219-225$.

2. Tambe KA, Ambekar SW, Bafna PN. Dellenan (oculocerebrocutaneous) syndrome: few variations in a classical case. Eur J Paedatr Neurol 2003;7:77-80.

3. Pasquale LR, Romayananda N, Kubacki J, Johnson MH, Chan GH. Congenital cystic eyc with multiple ocular and intracranial anomalies. Arch Ophthalmol 1991;109:985987.

4. Nafs GG, van der Vliet AM, Hew JM. The oculocerebrocutaneous (DellemanOorthuys) syndrome. Neuroradiology 1999;41:55-59.

5. Delleman JW Oorthus JWE. Orbital cyst in addition to congenital cerebral and focal demal malformations: A new entity? Clin Genet 1981;19:191-198.

6. Delleman JW, Oorthuys JWE, Bleeker-Wagemakers EM, ter Har BGA, FergusonJW. Orbital cyst in addition to congenital cerebral and focal dermal malformations: a new entity. Clin Genet 1984;25:470-472.

7. Moog U, Kriger $\mathrm{G}$, Stengel B, de Die-Smulders C, Dykstra S, Bleeker-Wagemakers $\mathbf{E}$. Oculocerebrocutaneous syndrone, a case report, a follow-up, and differential diagnostic considenations. Genet Couns 1996:7:257-265.

8. Nabbay G, Meire F, Verloes A, Casteds I, Devos E. Ocular manifestations in Delleman syndrome (oculocerebrocutaneous syndrome, OCC- syndrome) and encephalocomiocutaneous liponatosis (ECCL). Bull Soc Belg Ophtalmol 1996;261:65-70.

9. Hennekm RCM, Beener FA, Bleeker-Wagemakers LM, Hamel BCJ, Oorthuys HWW. Oculocerebrocutanecus syndrome. J Med Genet 1990;27:69-70.

10. Naunchilk 1, llyina H, Rumantseva N. Delleman syndrome, a new case report. Medizinische Genetik 1996,8:42.

11. Boddaert $N$, Klein O, Ferwuson $N$, Sonigo P, Parisot D. Hertz-Pannier $L$, Baraton J, Emond S, Simon I, Cligot V, Schnit P. Pierte-Kahn A, Brunele F. Intellectual prognosis of the Dandy-W/alker malfomation in children: the importance of vemian lobulation. Neuroradiology $2003 ; 45: 320-324$. 
12. Parisi MA, Dobyns WB. Human malformations of the midbrain and hindbrain: review and proposed classification scheme. Mol Genet Metab 2003,80:36-53.

13. Alfonso I, Lopez PF, Cullen RF Jr, Martin-Jimenez R, Bejar RL. Spinal cord inwolvement in encephalocraniocutaneous lipomatosis. Pediatr Neurol 1986;2:380-384.

14. Bamforth JS, Riccardi VM, Thisen P, Chitayat D, Friedman JM, Caruthers I, Hall JG. Encephalocraniocutaneous lipomatosis: report of two cases and review of the literature. Neurofibromatosis 1989;2:166-173.

15. Grimalt $R$, Ermacora E, Mistura L, Russo $G$, Tadini GL, Triulzi F Gavichini $S_{\text {, }}$ Rondanini GF, Caputo R. Encephalocraniocutaneous lipomatosis: case report and review of the literature. Pediatr Dermatol 1993;10:164-168.

16. Nowaczyk MJ, Mernagh JR, Bourgeois JM, Thompson PJ, Jurriaans E. Antenatal and postnatal findings in encephalocraniocutaneous lipomatosis. Am J Med Genet 2000;91:261-266.

17. Parazzini C, Triulzi F, Russo G, Mastrangelo M, Sconti G. Encephalocraniocutaneous lipomatosis: complete neuroradiologic evaluation and follow-up of two cases. Am d Neuroradiol 1999;20:173-176.

18. Schrander-Stumpel CT, de Die-Smulders CE, Hennekam RC, Fryns JP, Bouckaert PX, Brouwer OF, da Costa JJ, Lommen EJ, Maswinkel-Mooy PD. Oculoauriculovertebral spectrum and cerebral anomalies. J Med Genet 1992;29:326-331.

19. Leichtman LG, Wood B, Rohn R. Anophthalmia, cleft lip/palate, facial anomalies, and CNS anomalies and hypothalamic disorder in a newbom: a midline developmental field defect. Am』Med Genet 1994;50:39-41.

20. Angle $B, H e r s h H$. Anophthalmia, intracerebral cysts, and cleft lip/palate: expansion of the phenotype in oculocerebrocutaneous syndrome? AmJ Med Genet 1997;68:39-42.

21. Ming JE, Katowitz J, McDonald-McGinn DM, Schnur RE, Hunter JV, Zackai EH. Hemifacial microsomia in a newborn with hypoplastic skin lesions, an eyelid tag, and microphthalmia: an unusual presentation of Delleman syndrome. Clin Dysmorphol 1998;7:279-283.

22. McCandless $\mathrm{SE}$, Robin $\mathrm{NH}$. Severe oculocerebrocutaneous (Delleman) syndrome: overlap with Goldenhar anomaly. Am J Med Genet 1998;78:282-285.

23. Goltz RW. Focal demal hypoplasia syndrome: an update. Arch Dernuatol $1992 ; 128: 1108-1111$.

24. Hall-Craggs MA, Harbord MG, Finn JP, Brett E, Kendall BE. Aicardi syndronna: MR assessment of brain structure and myelination. Ams J Neuroradiol 1990;1:532-536.

25. Barkovich AJ, Simon EM, Walsh CA. Callosal agenesis with cyst. A betrer understanding and new classification. Neurology 2001;56:220-227.

26. Jageerhussain $M$, Dhinagar $S$. Nadaradjan $S$, Bhat BV. Aicardi syndrome with DandyWalker malformation. Indian Pediatr 2000;37:673-676.

27. Clericuzio C. Oculocerebrocutaneous syndrome and the family of neurodemal disorders: developmental considerations. Proc Greenwood Genet Cent 1990;9:74.

28. Wilson RD, Traverse L, Hall JG, Flodmark CO, Rootman J. Oculocenebrocutancous syndrome. Am J Ophthalmol 1985;99:142-148. 


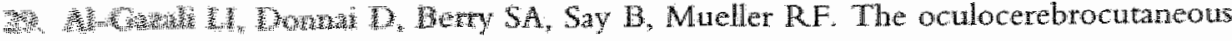

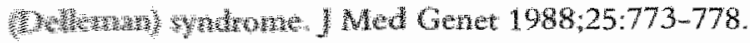

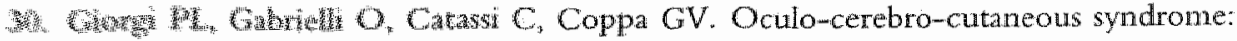

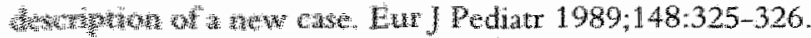

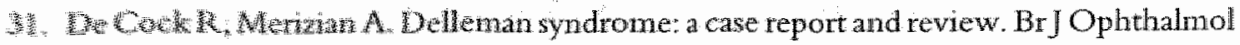

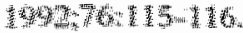

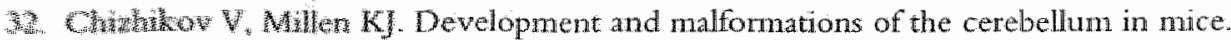

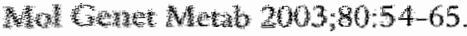

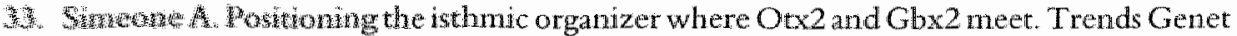

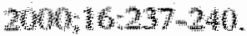

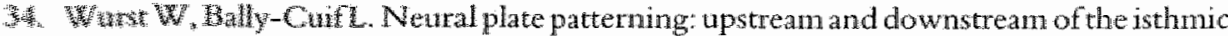

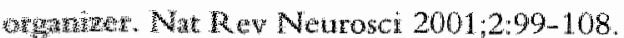




\section{CYTOGENETIC STUDIES}

4.1 Evolution of techniques 68

4.2 Benefit of combined techniques: Chromosome bands and ends revisited Am J Med Genet 2003;121A:88-89 (Letter) $\quad 77$

4.3 Subtelomeric chromosome aberrations: still a lot to learn Clin Genet 2005 Atigust 25 (online publication date) 81

4.4 Prevalence of cytogenetic aberrations in mental retardation 101 


\subsection{EVOLUTION OF TECHNIQUES}

\section{G-banding and high-resolution (HR) analysis}

In 2005 , we can look back at more than a half century of analysis of human chromosomes. Chromosomes are most often studied in a culture of peripheral $T$ lymphocytes using a heparinized blood sample after vena puncture. The mitotic cell division is first stimulated by phytohemagglutinin and then arrested in the metaphase. In 1952, the introduction of a hypotonic treatment of the lymphocyte culture allowed the distinction of each of the human chromosomes. However, it still took 4 years to fix the human chromosome number to 46 (Tjio \& Levan, 1956); prior to that time, it had been believed that there were 48 . In the beginning, unbanded equally coloured chromosomes were obtained which could be divided by length and localisation of the centromere into groups $A-G$. (autosomes) with group $C$ including the sex cluromosomes $X$, and the sex chromosome $Y$. Only numerical and rough structural anomalies could be detected. In 1959. Down syudrome was found to be caused by trisomy of a chromosome of the $G$-group (Lejeune at al, 1959) which later was identified as chromosome 21. Around 1970, different banding techniques were discovered utilizing either fluorescent dyes or the Giemsa stain (G-banding) (Caspersson et al., 1970; Sumner et al., 1971). Each chromosome then could be distinguished by a particular banding pattern.

In the mid-1970s, analysis of chromosomes at a higher resolution became feasible by blocking the cell division in the prometaphase when chromosomes are longer (Yunis et all, 1976). This was the birth of the socalled high resolution (HR) chromosome analysis which subsequently was refined step-by-step. Nowadays, HRGbanding with at least 500-550 bands per haploid set is the gold standard of chromosome analysis. On microscopic examination, the chromosome band resolution can be accurately and simply established by the sum of bands on chromosome 1 and 2 multiplied by 6 (Welbom \& Welborn, 1993). For a rough estimation and as a rule of thumb, at a level of 550 bands, chromosome 11 phows three distinct bands (p12; p14; p15.4) and band 22 q 13.2 is visible.

The analysis of well spread chromosomes with a resolution of at least 550 bands per haploid set permits the detection of rather subtle aberrations; dependent on the chromosome region involved, small deletions and duplications of about $5 \mathrm{Mb}$ can become visible. For example, in 60-70\% of cases of Wolf-Hirschhorn syndrome (deletion 4 p 16), or in $90 \%$ of cases of Smith-Magenis syndrome (deletion 17p 1 1.2) the deletions can be detected cytogenetically by HR analysis (Juyal et al , 1996; Battaglia et al., 2001\%. In the remaining cases, the deletion is too small for direct visualization, and additional FISH investigation is needed (see below). If a patient with MR has been subjected to chromosome analysis in the past, it is of 
particular importance to check the quality and resolution of this analysis, as technical improvements during the last decades meanwhile allow the detection of many more subtle imbalances. If a resolution of merely 400 bands or less per haploid set of human chromosomes was achieved during the previous analysis, the chromosome investigation should be repeated following a HR standard method if the MR is still unexplained. Examples of the detection of chromosomal anomalies on re-evaluation of patients with $M R$ are given in chapter 4.2 .

\section{Fluorescence in-situ hybridization (FISH)}

In the late 1970s, a technique was introduced which revolutionized the cytogenetic field by linking it to molecular techniques: the Fluorescent In-Situ Hybridization (Rudkin \& Stollar, 1977). The acronym FISH turned out to be a lucky choice as it became possible to fish and visualise each required DNA fragment. Basically, the method requires that a specific DNA fragment (a probe) is (1) labelled with a reporter molecule, (2) the probe is subsequently hybridized to denatured DNA of chromosomes or nuclei which have been immobilized on a microscope slide, and (3) the hybridized probe is subsequently detected with an antibody-fluorochrome complex directed against the reporter (Trask, 1991). The probe is chosen to bind to a complementary sequence, and thus to produce a signal at the site of hybridization and reveal its presence or absence. FISH thus depends in particullar on the availability of appropriate DNA probes for hybridization. The FISH technique was further developed in the late 1980 s (Lichter et al., 1988). For the analysis of chromosome aberrations, in particular three types of probes are used for numerous applications (for review see $\mathrm{Xu} \&$ Chen, 2003; Salman et al., 2004):

- Whole chromosome panting (WCP) probes consist of a library of probes with affinities to a particular chromosome and stain ("paint") it over its entire length, with the exception of the centromenc and telomeric regions. WCP probes are mainly used for the detection of rearrangements involving two or more chromosomes, e.g. balanced and unbalanced translocations and insertions. In the cytogenetic evaluation of $\mathrm{MR}$, the painting of all chromosomes with different colours (so-called "total paint') has proven particularly useful for the work-up of familial cases of $M R$, as obligate carriers of subtle balanced translocations can be easily detected (see chapter 4.3). In recent years, two multicolor karyotyping techniques have arisen from the use of WCP probes: M-FISH and SKY (see below).

- Chromosome-specific repetitive sequence probes hybridize near the centromere and are in particular used for FISH on non-dividing (interphase) cells. Interphase FISH can be used to score a large number of cells or to detect abnomalities preferentially present in non-dividing cells (Xu \& Chen, 
20us). W is aptlied, among others, for the detection of mosaic chromosome aberations, eng isochromosome $12 \mathrm{p}$ in mosaic state (Pallister-Killian syndrome on direct buccal smear preparations (Manasse et al., 2000).

- Unique sequance probes are used to identify specific chromosome anomalies: stbte defetions/duphications, translocations, inversions, and marker chromosomes. The size of the probes varies considerably from $1 \mathrm{~Kb}$ to $1 \mathrm{Mb}$, dependent on the target size. They can be applied to both metaphase and interphase preparations. Because the chromatin of nuclei is much less condensed in the interphase than during cell division, interphase FISH is very applatabe for the analysis of loci that are close together, e.g. for the characterization of microdeletions and duplications.

FSH with unique sequence probes is often used in the cytogenetic evaluation of MR: for the confirmation of a clinically diagnosed chromosomal abuormality, the elucidation of syndromes of possibly chromosomal origin, the characterization and refinement of abnormalities found by HR analysis, and for the study of genotype-phenotype correlations (for illustration see Moogetal., 1994; Moog et al., 1996; Mooget al., 2000; Moog et al., 2004). FISH is particularly often used for the detection or confirmation of microdeletion syndromes. Selected examples are listed in Table 4.I, other examples are Angelman, Prader-Willi and Rubinstein-Taybi syndromes (see Table 5.1). Many of these syndromes are contiguous gene syndromes, i.e. syndromes with variable clinical manifestations depending on the size of the deletion and the involvement of contiguous genes. If reproduction is possible, microdeletion syndromes behave as autosomal dominant traits.

A particular subset of unique sequence probes are subtelomeric probes which are used to detect cryptic translocations or imbalances involving the subtelomeric region. In 1995, the era of systematic investigation for subtelomeric rearrangements began with the study of Flint (Flint et al., 1995), although the power of FISH techniques had been used earlier to detect cryptic and subtelomeric anomalies. The issue will be discussed in detail in chapter 4.3 .

\section{Microdissection}

In 1986, microdissection, i.e. the physical dissection of a part of a G-banded chromosome with a micro-needle, became possible for human chromosomes (Bates et al., 1986), and subsequently could be combined with FISH in the so-called micro-FISH technique. Micro-FISH comprises four steps: the microdissection of chromosomal material, the amplification of the separated chromosomal fragment by PCR (polymerase chain reaction), its labeling with a fluorescent reporter molecule, and lastly its hybridization to a normal metaphase (Engelen, 1998). 
Table 4.I: Selected well-known microdeletion syndromes

\begin{tabular}{|c|c|c|c|}
\hline $\begin{array}{l}\text { Chromosome } \\
\text { region deleted }\end{array}$ & Condition & Major features. & CGS \\
\hline $\operatorname{Del}(4) p 16$ & $\begin{array}{l}\text { Wolf-Hirschinorn } \\
\text { syndrome }\end{array}$ & $\begin{array}{l}\text { Severe MR } \\
\text { Pre/postnatal growth retardation } \\
\text { Distinct facies } \\
\text { Congenital anomalics }\end{array}$ & + \\
\hline Del(5)p 15 & $\begin{array}{l}\text { Cri-du-chat } \\
\text { syndrone }\end{array}$ & $\begin{array}{l}\text { Severe MR } \\
\text { Catt-like cry } \\
\text { Microcephally, nound face, typical face }\end{array}$ & + \\
\hline $\operatorname{Del}(7) q^{1} 1.2$ & $\begin{array}{l}\text { Williams } \\
\text { syndrome }\end{array}$ & $\begin{array}{l}\text { MR } \\
\text { Typical facies } \\
\text { Characteristic behaviour } \\
\text { Cardiac defects }\end{array}$ & + \\
\hline $\operatorname{Del}(11) p 13$ & $\begin{array}{l}\text { WAGR } \\
\text { syndrome }\end{array}$ & $\begin{array}{l}\text { Wilnis tumor } \\
\text { Aniridia } \\
\text { Gonadoblastona } \\
\text { MR }\end{array}$ & + \\
\hline $\operatorname{Del}(11) \mathrm{q} 23.3$ & $\begin{array}{l}\text { Jacobson } \\
\text { syndrone }\end{array}$ & $\begin{array}{l}\text { MR } \\
\text { Growth retardation } \\
\text { Craniostenosis } \\
\text { Cardiac defects }\end{array}$ & - \\
\hline Del(8)q24.1 & $\begin{array}{l}\text { Langer-Giedion } \\
\text { syndrome }\end{array}$ & $\begin{array}{l}\text { Multiple exostoses } \\
\text { Bulbous nose, peculiar face } \\
\text { Sparse scalp hair } \\
\text { Mild MR dependent on delletion size }\end{array}$ & + \\
\hline Del(17)p 1.2 & $\begin{array}{l}\text { Smith-Magenis } \\
\text { syndrome }\end{array}$ & $\begin{array}{l}\text { MR } \\
\text { Characteristic behaviour } \\
\text { Typical facies }\end{array}$ & + \\
\hline Dell(17)p13.3 & $\begin{array}{l}\text { Miller-Dieker } \\
\text { syndrome }\end{array}$ & $\begin{array}{l}\text { Profound MR, seizures } \\
\text { Lissencephaly } \\
\text { Microcephaly, typical facies. }\end{array}$ & + \\
\hline $\operatorname{Del}(22) \mathrm{q} 11.2$ & $\begin{array}{l}22 \text { gll syndrome, } \\
\text { includes: } \\
\text { Velocardiofacial (VCF) s. } \\
\text { DiGeorge syndrome }\end{array}$ & $\begin{array}{l}\text { DD/leaming problems } \\
\text { Abnomalities of } 3 \text { rd }+4 \text { th pharyngeal pouches } \\
\text { Cardiac onttiow detects } \\
\text { Cleft palate/velopharyngeal insufficiency } \\
\text { Hypocalcaemia } \\
\text { Renal abnomality }\end{array}$ & - \\
\hline
\end{tabular}

Legend: CGS: contiguous gene syndrome 
Micro-FISH can identify chromosome abnormalities when HR-karyotyping and FISH alone turn out to be insufficient. The most important applications are the identification of small, mosaic or complex marker chromosomes of any origin, the characterization of complex rearrangements, e.g. translocations, and the sophisticated delineation of deletions and duplications (Engelen et al. 1996a; Engden et al., 1996b; Engelen et al., 1996c). Another advantage is that also longterm stored specimens can be used for microdissection.

\section{Techniques arisen from FISH}

During the last decade, a number of further techniques has been developed from FISH. The most important ones will be mentioned:

- Techniques of differential chromsome painting: M-FISH (multicolour FISH) (Speicher et al., 1996; Eils et al., 1998; Uhrig et al., 1999) and SKY (spectral karyotyping) (Sichröck et al., 1996; Macville et al., 1997; Schröck et al., 1997) both emerged from whole chromosome painting (WCP). They essentially consist of simultaneous WCP painting of all chromosomes in a single experiment followed by subsequent computer-assisted spectrum analysis of the colour signals achieved; they differ in the manner of the imaging process. All WCP based analyses have two major limitations: they are inadequate for the detection of intrachromosomal rearrangements as deletions, duplications and inversions; and their resolution is restricted to 1-3 MB (Lee et al., 2001). They are most often used in combination with other techniques.

- Conventional or chromosome CGH (comparative chromosome hybridization) is a teclanique which screens all chromosomes for imbalances by comparing the DNA content of the cells under investigation with that of a normal reference genome. It is based on two-colour fluorescent labeling of the specimen and the reference DNA, and hybridization of both to nomal metaphase chromosomes. Copy number changes (gains and losses) of DNA sequences in the specimen can be detected and localized by a shift of the fluorescence ratio to one of the colours (for review see Kirchhoff et al., 2001; Salman et al., 2004). For this technique, neither dividing cells nor parental samples are necessary. It can also be applied to formalin-fixed, paraffinembedded, or frozen samples. The sensitivity however is usually considered to be low (4-10 Mb), and can be maximally improved to $3 \mathrm{Mb}$ when using the high resolution CGH technique (Kirchhoff et al, 2001). Furthermore, balanced rearrangements cannot be detected, and, in particular, subtelomeric imbalances may be missed. These factors contribute substantially to the limitation of conventional CGH in the evaluation of MR (Joly et al., 2001; Ness et al., 2002; Kirchhof et al., 2004). 
Chromosome CGH is not a high-throughput technique. Meanwhile, this and other cytogenetic techniques have to compete with array-based formats (array CGH) and other new technologies which are faster, have a higher resolution, can be standardized more readily, and which are amenable for high-throughput analyses. (Ried, 2004). These will be discussed in chapter 7.2 .

Having found a normal karyotype by HR-banding, different pathways may be followed for further work-up depending on the clinical presentation ( $\mathrm{Xu} \&$ Chen, 2003). In patients with features of mosaicism such as body asymmetry and linear or patchy pigmentary changes, additional chromosome counts, or investigations in other tissues e.g. buccal smear or fibroblasts, are needed. When a microdeletion syndrome is suspected, additional FISH studies are required. Not infrequently, several techniques have to be combined to detect and further characterize a subtle anomaly or complex rearrangement. The following chapter (4.2) illustrates that a thorough application of (different) techniques of classical and molecular cytogenetics can enable the diagnosis of patients who on a first investigation were assumed to have a normal karyotype. This is followed in chapter 4.3 by a discussion of subtelomeric abnormalities and the ways to detect them. A synopsis of the prevalence of cytogenetic anomalies in MR as found by classical cytogenetic investigations and by subtelomeric studies, will close the part on Cytogenetic Studies.

\section{REFERENCES}

Bates GP, Wainwricht BJ, Williamson R, Brown SDM. 1986. Microdissection of and microcloning from the short arm of human chromosome 2. Mol Cell Biol 6:3826-3830.

Battaglia A, Carey JC, Wright TJ. 2001. Wolf-Hirschhorn (4p-) syndrome. Adv Pediatr 48:75-113.

Caspersson T, Zech L, Johansson C. 1970. Differential banding of alkylating fluorochromes in human chromosomes. Exp Cell Res 60:315-319.

Eils R, Uhrig S, Saracoglu K, Satzler K., Bolzer A, Petersen I, Chassery I, Ganser M, Speicher MR. 1998. An optimized, fully antomated system for fast and accurate identification of chromosomal rearrangements by multiplex-FISH (M-FISH). Cytogenet Cell Genet $82: 160-171$.

Engelen JJM, Albrechts JCM, Loots WJG, Hollanders-Crombach HTM, Hamers AJH, Geraedts JPM. 1996c. Application of microm.FISH to delineate deletions. Cytogen Cell Genet 75:167-171.

Engelen JJM, Loots WJG, Albrechts JCM, Motoh PCC, Fryns JP, Hamers AJH, Geraedts JPM. 1996b. Disclosure of five breakpoints in a complex chromosome rearrangement by microdissection and FISH.J Med Genet 33:562-566. 
Engelen JJM, Loots WJG, Motoh PCC, Moog U, Hamers AJH, Geraedrs JPM. 1996 . Marker chromosome didentification by Micro-FISH. Clin Genet 49:242-248.

Engelen JMM. 1998. The application of micto-fish in clinical cytogenetics [Thesis]. Maastricht: Maastricht Universiry. ISUN 9090114270.

FlintJ, Wilkie AO, Buckle VJ, Winter RM, Holland AJ, McDennid HE. 1995. The detection of subtelomeric chromosomal rearangements in idiopathic mental retardation. Nat Gener 9:132-140.

Joly G, Lapierre J-M, Ozilou $C$, Gosset P, Auriag $A$, de Blois M-C, Prieur M, Raoul O, Colleaux I, Munnich A, Romana SP. Vekemans M, Turleau C. 2001. Comparative genomic hybridisation in mentally retarded patients with dysmorphic features and a nomal karyotype. Clin Genet 60:212-219.

Juyal RC. Figuera LE, Hauge X, Elsea SH, LupskijR, Greenberg F, Baldini A, Patel PI. 1996. Molecular analyses of $17 \mathrm{p} 11.2$ deletions in 62 Smith-Magenis syndrome patients. Am J Hum Genet 58:998-1007.

Kirchhoff M, Pedersen S, Kjeldsen E, Rose H, Duno M, Kolvraa S, Lundsteen C. 2004. Prospective study comparing HR-CGH and subtelomeric FISH for investigation of individuals with mental retardation and dysmorphic features and an update of a sudy using only HR-CGH. Am J Med Genet 127A:111-117.

Kirchhoff M, Rose H, Lundsteen C. 2001. High resolution comparative genomic hybridisation in clinical cytogenetics. J Med Genet 38:740-744.

Lee C, Gisselsson D, Jin C, Nordgren A, Ferguson DO, Blennow E, Fletcher JA, Morton CC. 2001. Limitations of chromosome classification by multicolor karyotyping. Am J Hum Genet 68:1043-1047.

Lejeune L, Gautier M, Turpin R. 1959. Etudes des chromosomes somatiques de neuf enfants mongoliens. CR Acad Sci 248:1721.

Lichter P, Cremer T, Borden J, Manuelidis L, Ward DC. 1988. Delineation of individual human chromosomes in metaphase and interphase cells by in situ suppression hybridization using recombinant DNA libraries. Hum Genet 80:224-234.

Macville M, Veldman T, Padilla-Nash H, Wangad D, O'Brien P, Schrock E, Ried T. 1997. Spectral karyotyping, a $24-c o l o u r$ FISH technique for the identification of chromosomal rearrangements. Histochem Cell Biol 108:299-305.

Manasse BF, Lekgate N, Pfaffnzeller WM, de Ravel TJ. 2000. The Pallister-Killian syndrone is reliably diagnosed by FISH on buccal mucosa. Clin Dysmorphol 9:163-165.

Moog U, Engelen J, Albreches J, Hoorntje T, Hendrikse F, Schrander-Stumpel C. 1996. Alagille syndrome in a family with duplication 20p11. Clin Dysmorphol 5:279-288.

Moog U, Engelen JJM, Albrechts JCM. Baars LGM, de Die-Smulders CEM. 2000. Familial dup (8) (p12p21,1): mild phenotypic effect and review of partial $8 \mathrm{p}$ duplications. AmJ Med Genet 94:306-310.

Moog U, Engelen JM, de Die-Snullders CEM, Albrechts JCM, Loneus WH, Haagen AAM, Raven EJM, Hamers AJH. 1994. Partial trisomy of the short arm of chromosone 18 due to inversion duplication and direct duplication. Clin Genet 46:423-429. 
Moog U, Engelen JJM, van Schrojenstein Lantman-de Valk HMJ, Driessen SD, Fryns JP. 2003. Familial cryptic translocation with deletion 4q33->4qter and duplication $7 \mathrm{q}$ 34t $>7$ qter in brothers with mental retardation, macrocephaly and iriscoloboma. Clin Dysmorphol 12:35-39.

Moog U, Engelen JIM, Weber BW, Gelderen M van, Steyaert J, Baas F, Sijstemans HMJ, Fryns JP. 2004. Hereditary motor and sensory neuropathy (HMSN) IA, developmental delay and autism related disorder in a boy with duplication (17) (p11.2p12). Genet Counsel $15: 73-80$.

Ness GO, Lybek H, Houge G. 2002. Usefulness of high-resolution comparative genomic hybridization (CGH) for detecting and characterizing constitutional chromosome abnormalities. Am J Med Genet 113:125-136.

Rudkin GT, Stellar BD. 1977. High resolution detection of DNA-RNA hybrids in situ by indirect immunofluorescence. Nature 265:472-473.

Salman M, Jhanwar SC, Ostrer H. 2004. Will the new cytogenetics replace the old cytogenetics? Clin Genet 66: 265-275.

Sumner AT, Evans HJ, Buckland RA. 1971. New technique for distingushing between human chromosomes. Nat New Biol 232:31-32.

Schröck E, du Manoir S, Veldman T, Schoell B, Wienberg.J, Ferguson-Smith MA, Ning Y, Ledbetter DH, Bar-Aun I, Soenksen D, Garini Y, Ried T. 1996. Multicolor spectral karyotyping of human chromosomes. Science 273:494-497.

Schröck E, Veldman T, Padilla-Nash H, Ning Y, SpurbeckJ,Jalal S, Shaffer LG, Papenhausen P, Kozma C, Phelan MC, Kjeldsen E, Schonberg SA, O'Brien P, Biesecker L, du Manoir $\mathrm{S}$, Ried T. 1997. Spectral karyotyping refines cytogenetic diagnostics of constitutional chromosomal abnormalities. Hum Genet 101:255-262.

Speicher MR, Gwyn Ballard S, Ward DC. 1996. Karyotyping human chromosomes by combinatorial multi-thor FISH. Nat Genet 12:368-375.

Tjio JH, Levan A. 1956. The chromosome number in man. Hereditas 42:1.

Trusk BJ. 1991. Fluorescence in situ hybridization: applications in cytogenetics and gene mapping. TIG 7:149-154.

Uhrig S, Schuffenhauer S, Fauth C, Wirtz A, Daumer-Has C, Apacik C, Cohen M, MullerNavia], Cremer T, Murken], Speicher MR. 1999. Multiplex-FISH for pre-and postnatal diagnostic applications. Am J Hum Genet 65:448-462.

Welborn JL, Welborn R. 1993. Banding resolution of human chromosomes: a method of accuracy and simplicity. Am J Med Genet 47:1180-1183.

Xu J, Chen Z. 2003. Advances in molecular cytogenetics for the evaluation of mental retardation. Am J Med Genet 117C:15-24.

Yunis JJ. 1976. High resolution of human chromosomes. Science 191:1268-1270. 
70 CHAPTER 4 


\title{
4.2 Benefit of combined techniques:
} Chromosome bands and ends revisited

\author{
Moog $U^{1,2}$, Engelen JJM ${ }^{1,2}$, Schrander-Stumpel CTRM ${ }^{1,2}$, \\ Jean-Pierre Frijns ${ }^{1,3}$
}

'Department of Clinical Genetics, Uniwersity Hospital Maastricht, Maastricht, The Netherlands; "Research Institute Growth \&. Development (GROW), Mastricht University, Maastricht, The Netherlands; 3Center for Human Genetics, University Hospital Gasthuisberg. University of Lequen, Leuven, Belgium. 
In this Joumal, we read with great interest the editorial comment by Biesecker on "The end of the beginning of chromosome ends" (Am J Med Genet 2002;107:263-266). This editorial comments on three studies published in the same issue of the Journal and previous studies of subtelomeric chromosome aberrations as a cause of mental retardation. Biesecker speculated about the end of the subtelomeric era and future methodological advances, focusing hope on future universal (chip) rechnologies. However, there is no such technology in daily practice as yet. Working daily with patients with unexplained mental retardation (with or without dysmorphism or congenital anomalies) and making decisions on the necessary cytogenetic work-up, we sincerely appreciate Biesecker's efforts to give a concise review on an extensive topic and are grateful that he addressed the general aspects of the issue. Nevertheless, we felt that the title ("The end of ...") and the seeming dissatisfaction with currently available techniques had something fatalistic, irreconcilable with the optimistic (perhaps compelling?) attitude of most clinical geneticists.

Thus, we looked back to specific chromosome aberrations diagnosed on revision or work-up at the Department of Clinical Genetics at Maastricht, The Netherlands. In the Table below, we give examples of chromosome aberrations found through different additional techniques. Previously, all these patients had a normal karyotype result or an aberration that could not be completely classified (patients 6 and 7) on a first investigation by GTG-banding. The benefit of these ultimately successful diagnostic studies is their immediate impact on genetic counseling.

We admit that in retrospect, the dysmorphic features of patient 10 (microbrachycephaly, flat mid-face, prominent forehead, large anterior fontanelle, horizontal eyebrows, thin lower lip) were jugded as characteristic for deletion $1 \mathrm{p} 36$, but had not been previously recognized as such at national and international neetings by several expert dysmorphologists. We also note that in retrospect, after having diagnosed Charcot-Marie-Tooth $1 \mathrm{~A}$, patient 3 did have a tiny, but cytogenetically visible, duplication of $17 \mathrm{p}$. To most clinical geneticists, these are familiar aspects of etiological investigations.

The yield of subtelomeric screening cannot be translated into an unequivocal number of rearangements. Several studies have shown that the proportion of abnomal findings strongly depends on selection criteria and previous cytogenetic work-up. The paper by Riegel et al. [2001] not only gives an excellent review on the development of subtelomeric screening but also clearly shows the influence of preselection: a better initial clinical evaluation and cytogenetic pre-investigation by higher quality GTG-banded karyotype and region specific FISH when the clinical examination raised the suspicion of a specific aberration, results in a lower incidence of anomalies detected by subtelomeric screening. 
Table4. II: Clinical and cytogenetic findings in patients with chromosome aberrations diagnosed on revision or work-up

\begin{tabular}{|c|c|c|c|c|c|}
\hline $\begin{array}{l}\text { Pat } \\
\text { ner }\end{array}$ & Sex tage & 1 st analysis & Clinical features & Work-up by & Aberation \\
\hline 1 & $F_{x} 22 y$ & $\begin{array}{l}46, X X \\
(1976)\end{array}$ & $\begin{array}{l}\text { Severe MR, short } \\
\text { stature, microcephaly, } \\
\text { facial dysmorphism }\end{array}$ & HR, confirmed by FISH & $\begin{array}{l}\text { Oup }(4) \\
\left(\mathrm{q}^{3} \mathrm{q} \mathrm{q}^{3}+4\right)\end{array}$ \\
\hline 2 & $F_{n} 22 y$ & $\begin{array}{l}46, \times X \\
(1976)\end{array}$ & $\begin{array}{l}\text { Severe MR, short } \\
\text { stature, postaxial } \\
\text { polydactyly, facial } \\
\text { dysmorphism }\end{array}$ & $\mathrm{HR}$, confirmed by FISH & $\begin{array}{l}\operatorname{Del}(3) \\
(p 25,3 \rightarrow \text { pter })\end{array}$ \\
\hline 3 & $M, 6 y$ & $46, X Y$ & $\begin{array}{l}\text { Developmental delay, } \\
\text { Charcot-Marie-Tooth } \\
\text { 1A, autism spectrumi } \\
\text { disorder, subtle } \\
\text { dysmorphism }\end{array}$ & FISH + revision of HIR & $\begin{array}{l}\text { Dup(17) } \\
(p 11.2 p 12)\end{array}$ \\
\hline 4 & $F, 4 y$ & $\begin{array}{l}46, \times X \\
\text { in blood }\end{array}$ & $\begin{array}{l}\text { Small stature, } \\
\text { hemihypotrophy, } \\
\text { skeletal asymmetry, } \\
\text { retarded bone age }\end{array}$ & $\begin{array}{l}\text { GTG and FESH in } \\
\text { fibroblasts }\end{array}$ & Mos tris 22 \\
\hline 5 & M. $5 \mathrm{~m}$ & $\begin{array}{l}46, X Y \\
\text { in bllood }\end{array}$ & $\begin{array}{l}\text { Developmental delay, } \\
\text { facial features suggesting } \\
\text { Pallister-Killian } \\
\text { syndrome, hypospadia }\end{array}$ & $\begin{array}{l}\text { GTG and FISH in buccal } \\
\text { mucosa + fibroblases }\end{array}$ & $\mathbb{I s o}(12)(\mathrm{p} \mid 0)$ \\
\hline 6 & $M, 1 y$ & $\begin{array}{l}\text { Variant } 15 p \\
\text { or der(15)? }\end{array}$ & $\begin{array}{l}\text { Severe growth } \\
\text { retardation, MCA, facial } \\
\text { dysmorphism }\end{array}$ & Microdissection & $\begin{array}{l}\text { Der(15) } \\
(6 p t e r \rightarrow 6 p 221: \\
15 p 12 \rightarrow 15 q \text { per) }\end{array}$ \\
\hline 7 & $\mathrm{M}, 21 \mathrm{y}$ & Dup $(5 p)$ & $\begin{array}{l}\text { MR, behavioral } \\
\text { problems }\end{array}$ & Microdissection & $\begin{array}{l}\operatorname{Der}(5) \mathrm{r}(5 ; 13) \\
(\mathrm{p} 15.3 ; \mathrm{q} 22)\end{array}$ \\
\hline $\begin{array}{l}8 \\
+ \\
9\end{array}$ & $\begin{array}{l}\text { M, } 48 \mathrm{y} \\
\text { uncle }+ \\
\mathrm{M}, 27 \mathrm{y} \\
\text { nephew }\end{array}$ & $46, X Y$ & $\begin{array}{l}\text { Mild MR (uncle) } \\
\text { Moderate MR, MCA } \\
\text { (nephew) }\end{array}$ & $\begin{array}{l}\text { Total paint (carrien) } \\
\text { followed by FISH } \\
\text { (both patients) }\end{array}$ & $\begin{array}{l}\operatorname{Der}(4) \mathrm{t}(4 ; 18) \\
(q 35 ; p 11.3) \\
\text { in both }\end{array}$ \\
\hline 10 & $F, 1.5 y$ & $46, \times x$ & $\begin{array}{l}\text { Severe delay, hypotonia, } \\
\text { dysmorphism }\end{array}$ & Subtelomere sctedening & $\operatorname{Del}(1)(\mathrm{p} 36)$ \\
\hline $\begin{array}{l}11 \\
+ \\
12\end{array}$ & $\begin{array}{l}M, 41 y \\
M, 45 y \\
\text { brothers }\end{array}$ & $46, X Y$ & $\begin{array}{l}\text { Both: moderate MR, } \\
\text { macrocephaly, } \\
\text { iriscoloboma, belavional } \\
\text { problems }\end{array}$ & Subtelomere screcting & $\begin{array}{l}\operatorname{Der}(4) \mathrm{t}(4 ; 7) \\
\left(\mathrm{q} 33 ; \mathrm{q}^{34)}\right. \\
\text { in both }\end{array}$ \\
\hline
\end{tabular}

Legend: Fi fernale, M: male, y: year, m: months, MR: mental retardation, MCA: mulliple congenital anomalies "HR: high resolution GTG-banding, FISH: fluorescent in-situ hybridisation

Having used the gold standard of high resolution-GTG banding with at least 500 550 bands per haploid set, we conclude that there is not a single technique that can be used in the cytogenetic diagnostic work-up of patients with unexplained mental retardation. In different clinical situations, with varying clinical expertise, and different clinical testing resources, it is reasonable to use any one of, or a 
combination of approaches to diagnose these patients. Up to now, we lack a single assay that is easy to use, reliable and inexpensive that detects balanced and unbalanced aberrations, in mosaic or non-mosaic form, at the beginning of chromosome ends and all bands in berween. But we do have powerful techniques detecting growing number of aberrations and should use them as conscientiously and effectively as possible - until there are better ones.

\section{REFERENCES}

Biesecker L. 2002. The end of the beginning of chromosome ends. Am J Med Genet 107:263266.

Riegel M, Baumer A, Jamar M, Delbecque K, Herens C, Verloes A, Schinzel A. 2001. Submicroscopic terminal deletions and duplications in retarded patients with unclassified malfornation syndromes. Hum Genet 109:286-294. 
4.3 Subtelomeric chromosome aberrations: still a lot to learn

Moog $\mathrm{U}^{1,2}$, Arens YHJM', van Lent-Albrechts JCM', Huijts PEA', Smeets EEJ', Schrander-Stumpel CTRM ${ }^{1,2}$, Engelen JJM ${ }^{1,2}$

'Department of Clinical Genetics, University Hospital Maastricht, and "Research Institute Growth \& Development (GROW), Mastricht University, Maastricht, The Netherlands. 


\section{ABSTRACT}

Cryptic subtelomeric chromosome aberrations are a significant cause of mental retardation (MR). More than 4.000 patients have been investigated, and the mean overall prevalence of subtelomeric rearrangements has been found to be $5.2 \%$. In order to contribute to knowledge on the clinical presentation of subtelomeric rearrangements, we retrospectively studied patients with unexplained MR who had been evaluated for subtelomeric abnormalities by different fluorescence in situ hybridization (FISH) techniques. 102 patients had an unexplained combination of MR with dysmorphism, congenital anomalies and/or a positive family history, and were investigated by total subtelomeric FISH (TS) $(89 / 102)$, or by total painting (TP) in an obligate carrier in the case of familial MR (13/102). In 59 additional patients, a sequence-specific FISH was performed on clinical indication. In the 102 patients studied by TS or TP, 6 pathogenic aberrations (5.9\%) were found in addition to one polymorphism. In total, 8 clinically significant subtelomeric aberrations were found in the 161 index patients; 4 of these 8 aberrations were familial. We report on the clinical presentation of all patients with an aberration and review the relevant literature. Factors complicating the interpretation of subtelomeric rearrangements are discussed, such as the occurrence of variants, clinical variability, and limited knowledge of the phenotype.

Keywords: cryptic chromosome abnormalities, FISH, monosomy, subtelomeric rearrangements, trisomy 


\section{INTRODUCTION}

Cryptic subtelomeric chromosome aberrations are undetectable by conventional banding techniques either because of their small size or the similarity of segments involved and have been recognized as a major cause of mental retardation (MR) in 1993 (1). They can be screened for by different methods: fluorescent in sin hybridization (FISH) with a complete set of subtelomeric probes; techniques derived from $\mathbb{F I S H}$ such as multiple amplifiable probe hybridization (MAPH), multiplex ligation-dependent probe amplification (MLPA), and primed in situ labeling (PRINS); and by genotyping with genetic markers [for review see (2-4)]. Differential chromosome painting techniques such as spectral karyotyping (SKY) and multiplex FISH have been shown to be inadequate to detect small rearrangements $(3,5)$. Data on the sensitivity of chromosome comparative genomic hybridization (CGH) for the detection of small subtelomeric rearrangements are controversial (6-8). Microarray-based CGH is a new, promising high-throughput method for whole genome analysis; one application is the detection of subtelomeric imbalances $(9,10)$. To date, however, FISH with a commercially available set of probes is the most often applied technique established in most laboratories. Subtelomeric studies by FISH and its variants, genotyping, or array $\mathrm{CGH}$ has been reported in at least 36 studies on more than 4000 patients ffor review see (4), and in addition (10-27)]. The overall frequency of disease-related subtelomeric chromosome aberrations in these 36 studies summarized is about $5.2 \%$ ranging overall from $0-23 \%$, but in larger studies ( $\mathrm{n}>50$ ) from $0-16 \%$. It depends on the patient ascertainment criteria, cytogenetic pre-screening, and the expertise of the examining clinician $(2,28)$. A more sophisticated pre-screening at a high banding level or the clinical recognition of a particular phenotype which can be confirmed, e.g. by targeted FISH, lowers the yield of total subtelomeric screening (TS). Despite this large body of reported subtelomeric aneusomies, the literature on the clinical presentation and the pathogenicity of detected rearrangements is still limited.

In order to expand the knowledge on genotype-phenotype correlation, we retrospectively investigated the group of patients with unexplained MR studied at the Department of Clinical Genetics at Maastricht (Netherlands) for subtelomeric aberrations by TS FISH, total painting (TP) FISH and by targeted subtelomeric FISH. We report on the clinical presentation of detected anomalies, review the literature of these, and evaluate existing scoring lists for their detection. 


\section{PATIENTS AND METHODS}

161 index patients with unexplained developmental delay (DD)/ MR referred to the Department of Clinical Genetics at Maastricht, the Netherlands, were evaluated for subtelomenc abnomalities. All patients had nomal results on previous analysis of $\mathrm{GTG}$-banded chromosomes at a 550 band level and were examined by a clinical geneticist trained in dysmorphology. $102 / 161$ patients had unexplained MR with physical anomalies (dysmorphism or congenital malformations). In 13 cases of familial MR, TP in an obligate carrier was primarily performed. 89 patients were evaluated by TS FISH. In 59/161 patients, a specific subtelomeric aberration was suspected on clinical grounds, and a targeted subtelomeric FISH was done.

Chromosomes were prepared from peripheral blood lymphocyte cultures following standard procedures and GTG-banded by treatment with trypsin and staining with Giemsa. From each patient, $10-15$ metaphases were analyzed with a resolution of at least 550 bands per haploid set of chromosomes. TP was performed with the Chromoprobe Multiprobe system (Cytocell, Adderbury, UK) following the manufacturer's specifications. Total telomere analysis with FISH probes specific for the 41 subtelomere regions was performed with To'TelVision probes (Vysis, Downers Grove, IL) following the manufacturer's specifications. FISH with band-specific probes was performed as described by Lichter et al. (29). To estimate the respective sizes of two recurrent subtellomeric deletions, additional FISH analysis was performed with publically available probes from a $1-\mathrm{Mb}$ clone set (Sanger institute, Cambridge, UK): 635E18, $575 \mathrm{~L} 21,510 \mathrm{D} 11,484 \mathrm{P7}, 338 \mathrm{~N} 10,438 \mathrm{~L} 4,37 \mathrm{~J} 18,785 \mathrm{P} 20,465 \mathrm{~B} 22$, and $14 \mathrm{E} 10$ for chromosome region $1 \mathrm{p} 36.22-36.33$; and $546 \mathrm{M} 8,463 \mathrm{~B} 12$, and $556 \mathrm{H} 17$ for chromosome region $2 \mathrm{q} 37.3$ and in addition the subtelomeric probe $3 \mathrm{~K} 23$ (courtesy of Dr. J. Hoovers, Amsterdam).

\section{RESULTS}

Results are summarized in Table 1 . With total subtelomere analysis (TS), 5 of 89 index cases (5.6\%) were found to have a subteloneric imbalance; two patients had a de mow deletion 1 p36, and one patient had a deletion $2 \mathrm{q} 37$, which should be considered to be a polynorphism, as his Gather was a healthy carrier of the same aberration. Furthermore, two sib pairs with an unbalanced translocation deriving from familial translocations $t(4 ; 7)(\mathrm{q} 33 ; \mathrm{q} 34)$ and $t(16 ; 18)(\mathrm{q} 24.3 ; \mathrm{q} 23)$ were detected. In both cases, initial testing of both parents by TP was impossible. With TP, familial translocations were found in $2 / 13$ cases $(15 \%)$ : $t(4 ; 18)(\mathrm{q} 35 ; \mathrm{p} 11.31)$ and $\mathrm{t}(13 ; 20)(\mathrm{q} 34 ; \mathrm{p} 13)$. In the family with $\mathrm{t}(4 ; 18)$, patients 
with imbalances due to both derivative chromosomes were observed (patients 8 $10)$, and in the family with $t(13 ; 20)$, the index patient was shown to have inherited the derivative chromosome 13 (patient 11).

In $2 / 59$ patients (3.4\%) analyzed with only one subtelomeric FISH probe [targeted subtelomeric FISH (TF)], deletions were found: one deletion 10q26, and one deletion $2 \mathrm{q} 37.3$.

\section{CLINICAL REPORTS AND LITERATURE REVIEW}

\section{De novo rearrangements}

\section{Deletion 1 p 36}

The development of patient 1 was severely delayed from the beginning, and she was hypotonic. During the first years of life, she had feeding problems and gastroesophageal reflux and was susceptible to upper airway infections. Severe sensorineural hearing loss was diagnosed, and at age three years, she developed generalized epileptic seizures which were successfully treated with valproic acid. Around four years of age, she began to bite her hands, strike herself on the head, and scream. She developed an obsession to tense her abdominal muscles; lying on her back, she compulsively and simultaneously raised her stretched legs and her head and could stay for a long time in this position. On examination at five years, she could raise her head and roll over but could not sit stably unsupported and had no speech. She showed axial hypotonia and was free of seizures. Increasing behavioral and sleeping problems were major points of concern. However, she was a pleasant girl able to make good contact with her family. She showed brachymicrocephaly, a flat face, up-slanting palpebral fissures, and straight eyebrows (Fig.1). Cardiologic and ophthalmologic evaluations showed nomal results. A magnetic resonance imaging (MRI) scan of the brain revealed delayed myelinization. FISH with 10 probes covering chromosome region $1 \mathrm{p} 36.22$ 36.33 , showed that 510D11 was the most proximal probe to be deleted and that the deleted region was distal of probe $575 \mathrm{~L} 21$, indicating that the size of the deletion was at least $9 \mathrm{Mb}$. The deletion was however undetectable on analysis of GTG-banded chromosomes at a 550 band level.

Patient 2 showed DD and abnormal contact behavior from the beginning. As an infant, he also had feeding problems. He had a large, late-closing anterior fontanelle. At 16 months, generalized hypotonia was noticed, and he developed behavioral problems with autistic features, later also hyperactivity and tantrums. On examination at 13 years, he was a moderately to severely retarded friendly boy, whose behavior was dominated by autistic signs. He was able to walk, and to 


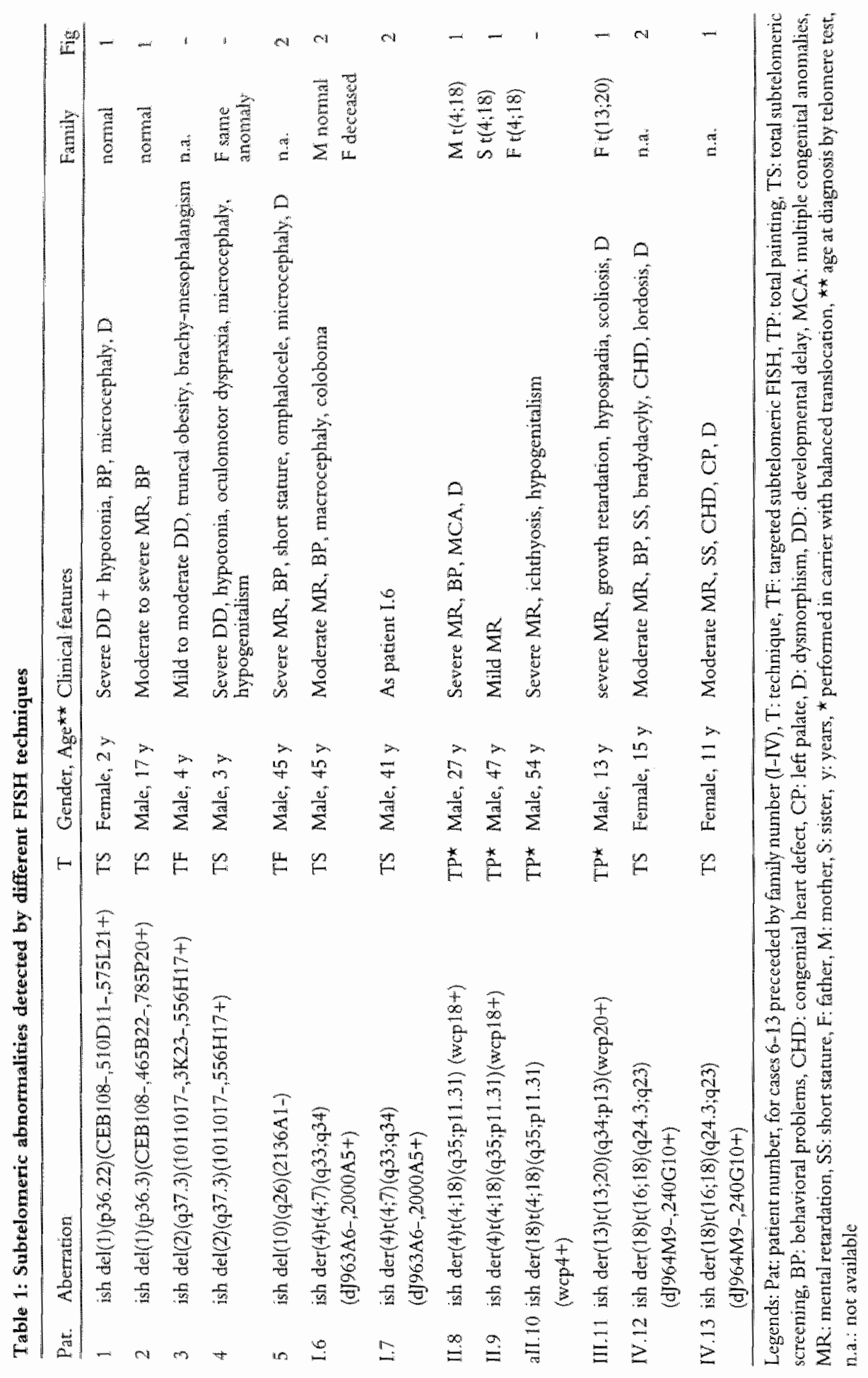


speak inarticulately. There were no neurological problems apart from generalized mild hypotonia. Height and weight were within the normal range, his head circumference was $52 \mathrm{~cm}(-1 \mathrm{SD})$. He had deep-set eyes, ears with thickened helices (Fig. 1), a mild scoliosis, and an asymmetric thoracic flattening on the right side. His hands had broad distal phalanges, and the distal phalanx of his left thumb was short. Ophthalmologic and audiologic examinations and a CT scan of the brain, showed normal results. FISH with probes $438 \mathrm{~L} 4,37 J 18,785 \mathrm{P} 20,465 \mathrm{~B} 22$, and $14 \mathrm{E} 10$, specific for chromosome region $1 \mathrm{p} 36.32-36.33$, showed that the deleted region was distal of probe $785 \mathrm{P} 20$, indicating that the size of the deletion was maximally $3.2 \mathrm{Mb}$.

Deletion 1 p36 is the most common subteloneric aneusomy, with a frequency of about $1 / 5,000(30)$. The deletion is visible by high resolution banding techniques in the majority of cases (31-32). Interstitial deletions, derivative chromosomes and complex rearrangements together form $30 \%$ of $1 \mathrm{p} 36$ monosomy, but presumably terminal deletions (70\%) may also be more complex on additional molecular study $(11,32) .1 \mathrm{p} 36$ deletions are maternally derived in about $65 \%$ of cases (30). The phenotype is characterized by moderate to severe retardation, hypotonia, often postnatal growth delay, and craniofacial dysmorphism as seen in patient 1 , with microbrachycephaly, a large anterior fontanelle, deep-set eyes, a flat nasal bridge, midface hypoplasia, ear anomalies and a pointed chin (31-34); the eyebrows may be strikingly straight and low-set (35). Seizures, eye or vision problems, and hearing deficit occur in $>50 \%$. Heart defects, cardiomyopathy, or orofacial clefting can be associated. Behavioral problems have been repeatedly reported in about half of the patients $(31,33,36)$. These include self-injurious behavior with hand biting and head striking, aggressiveness with banging or throwing objects, striking people and tantrums, hyperactivity, low frustration, and autism. Both patient 1 and 2 showed behavioral problems, patient 1 in combination with a hitherto unreported compulsive posture, whereas their facial phenotype and degree of retardation differed remarkably. It is possible, although this has yet to be further examined, that serious behavioral problems are a key feature of deletion $1 \mathrm{p} 36$. The difference in phenotype may be related to the different sizes of the deletion. So far, the discussion is, however, controversial whether the 1 p36 deletion syndrome is a true contiguous gene syndrome $(32,34,37)$.

\section{Deletion $2 q$}

Patient 3 was born as the furst child of healthy parents originating from Somalia. Delivery was at term, and growth parameters at birth were normal. When referred for pediatric evaluation because of DD at the age of 3 years 11 months, he was a mildly to moderately retarded boy with good general health. He had a normal height ( 0 to -1 SD for age), and a weight above 2 SD with truncal obesity. 
Head circumference was $53 \mathrm{~cm}(+1 \mathrm{SD})$; he had a high and prominent forehead but showed no other facial peculiarities. The fourth metacarpals were shortened bilaterally. Acanthosis was noticed in the neck, fitting with his ethnic background. Eye examination showed no retinal abnormalities. Because of mild to moderate retardation in association with his stature and brachymesophalangism, a cerminal $2 q$ deletion was suggested. This was confinmed by FISH with probes 101017 and $3 \mathrm{~K} 23$, specific for the subtelomeric region of chromosome $2 q$. FISH showed that the deleted region was distal of probe $556 \mathrm{H} 17$, indicating that the size of the deletion was at most $1.2 \mathrm{Mb}$. The parents were not a wailable for testing. The deletion is considered causative as it is known that the described phenotype can be caused by deletion 2 q 37 .

One further patient (patient 4) was shown to have a cryptic subtelomeric deletion $2 \mathrm{~g}$ on TS screening. Additional FISH with probes $556 \mathrm{H17}, 463 \mathrm{~B} 12$ and $546 \mathrm{M} 8$, specific for chromosome region $2 \mathrm{q} 37.3$ showed these probes to be non-delleted. As his healthy father showed the same FISH pattern, this abnomality was regarded as a variant.

Subtelomeric deletions of chromosome $2 q$ may cause phenotypic abnomalities, or may be present as variants without affecting the phenotype. The latter has mainly been deduced from the fact that these subterminal deletions also occur in normal parents and other family members, sometimes in several generations. In subtelomeric screening studies, a cryptic deletion $2 q 37.3$ has been found as a variant in $2-6 \%$ of cases $(11,16,17,19,24,38)$. The non-variant deletions are associated with heterogeneous phenotypes comparable to those caused by cytogenetically visible deletions $2 \mathrm{q} 37$. More than 60 patients have been reported with deletion $2 \mathrm{q} 37$ [for review see $(39,40)$ ]. So far, no convincing genotypephenotype correlation has been found. All patients exhibit MR and facial dysmorphism. About 50\% show Albright Hereditary Osteodystrophy (AHO) like syndrome with brachymetaphalangism, short stature and a stocky build. Contrary to AHO, Gs-alpha activity levels are normal, and there are no cutaneous ossifications in AHO-like syndrone (41). A recognizable facial phenotype with a round face, frontal bossing, prominent columella, and a thin upper lip may be present $(39,42)$. However, in deletion $2 \mathrm{q} 37$, a non-specific phenotype with moderate to severe $M R$, growth retardation and aspecific dysmorphism are also seen (43). Patients with monosony $2 \mathrm{q} 37$ are prone to epilepsy, autism and hyperkinetic behavior. Congenital heart defects, Wilms tumor, and urogenital anomalies can be associated (39). Cryptic teminal deletions so far are more often associated with AHO-like syndrome (17,40,44-46) than with non-AHO phenotypes $(17,24,28)$. A case of $\mathrm{AHO}$-like syndrome with a cryptic interstitial deletion $2 q 37.1-37.3$ has also been reported (47). In recent years, the minimal deleted interval has been narrowed to approximately $3 \mathrm{Mb}$, and GPR35, GPC1 and 
STK25 have been proposed as candidate genes for the AHO-like syndrome and for brachymetaphallangy in particular $(39,40,43,48)$.

\section{Deletion $10 q 26$}

Patient 5 was formerly described to have Noonan syndrome but was severely mentally retarded and had no speech. He was born with an omplialocele which had been surgically corrected. Behavioral problems became evident at an early age. Sensorineural hearing impaiment was diagnosed at 16 years. Eye, vision, and kidney abnormalities were ruled out by clinical investigations. Chromosome analysis in 1974 revealed a normal karyotype. On examination at age 45 years, he was short statured (height $151 \mathrm{~cm}$ ), microcephalic (head circumference $51 \mathrm{~cm}$ ) and had short, broad hands. His behavior was friendly, but overactive and selfdetermining. Because of his phenotype (Fig.2) with low set posteriorly rotated dysplastic ears, a broad nose, down-slanting palpebral fissures, hypertelorism, webbed neck, widely spaced nipples, and bilateral cryptorchism, a terminal $10 \mathrm{q}$ deletion was suspected and confirmed by targeted FISH. On chromosome analysis at a 550-band level, the deletion was now also seen.

Recently, Scigliano et al. reviewed the clinical features of 32 cases with de novo terminal deletions $10 \mathrm{q}$, and Irving et al. reported on 12 new cases with breakpoints in $10 \mathrm{q} 26.1$ to $10 \mathrm{~g} 26.3(49,50)$. These deletions are often cytogenetically visible. The clinical findings consist of MR of various degrees, postnatal growth retardation and a recognizable craniofacial phenotype with microcephaly, a triangular face, hypertelorism, strabismus, a broad nasal bridge, ear anomalies, and a short neck, as seen in patient 5 . About $25 \%$ of the patients develop behavioral problems such as hyperactivity, reduced attention span, and aggressive, destructive and self-injurious behavior (51). Urogenital anomalies and cardiac defects are common and should be screened for (50). Patients with cryptic subtelomeric deletion $10 \mathrm{q}$ sensu strictu have been infrequently reported (50). There are several reports of patients with a subterminal deletion of $10 \mathrm{q}$ in combination with other imbalances and no consistent phenotype (35).

\section{Familial translocations}

\section{Pantial Deletion 4q, Partial Duplication $7 q$}

Details of two brothers (patients 6 and 7) with MR, behavioral problems, macrocephaly and iris-coloboma due to monosomy 4q33-qter and trisomy $7 \mathrm{q} 34$-qter have been published previously (52) (Fig.2). No other comparable rearrangements or pure imbalances of the segments involved on chromosomes 4 and 7 have been reported. 


\section{Partial Deletion 4q, Pantal Duplication $18 p$}

Patient 8 was born with post-axial polydactyly of his right hand, and septal heart defects [atrial septal heart defect (ASD) and ventricular septal heart defect (VSD)] which necessitated later surgery. At 2 years and 9 months, he began to walk and was reported to be hypotonic and growth retarded. He had recurrent pneumonia and otitis. At 5 years, he developed a hyperkinetic, destructive and aggressive behavior. On examination at 27 years, he had moderate to severe $M R$, could speak words inarticulately, and had a nasal speech. He was cheerful, active, made good contact, and at that time, showed few behavional problems. He was short statured (height $1.65 \mathrm{~m}$, less than $-2.5 \mathrm{SD}$ ), very slender (weight $48.5 \mathrm{~kg}$ ) and had a head circumference of $54 \mathrm{~cm}$. He had short palpebral fissures, synophris, anteverted nares, a short philtrum and small ears with thickened helices (Fig, 1).

Several members of his mother's family were also mentally retarded, including an uncle (patient 9). Two sibs of his mother were born small for gestational age, had multiple congenital anomalies with cleft palate, and died during the first month of life. No miscarriages were reported in the family. Patient 9 was borderline to mildly mentally retarded without formal testing. He had neither congenital anomalies, nor medical or behavioral problems. He lived independently, had been married for 22 years and worked at a sheltered work place. On examination at 47 years, he had nomal growth and body habitus. He showed a small nose with anteverted nares and prominent ears, but no other dysmorphic signs (Fig.1). Both patient 8 and 9 had a normal karyotype on analysis of GTG-banded chromosomes at a 550 band level. A total paint in the mother of patient 8 , respectively, sister of patient 9 , revealed a cryptic reciprocal translocation $(4 ; 18)(q 35 ; p 11.31)$. Patient 8 and 9 were subsequently shown to have a $46, X Y$.ish der(4)t(4;18)(q35;p11.31)(wcp18+) karyotype with monosomy 4q35-qter and trisomy $18 \mathrm{p} 11.31$-pter. The discovery of the translocation led to re-examination and counseling of this large family. An unbalanced offspring with the derivative chromosome 18 and monosomy $18 \mathrm{p} 11.31$-pter and trisomy 4q35-qter was subsequently observed (patient 10). He had severe MR, ichthyosis, and hypogenitalism. Growth and posture were nomal; he had no neurological problems. He was formerly supposed to have Rud syndrome (OMIM 308200).

The involved $4 \mathrm{q}$ segment is smaller than the monosomic segments of patients 6 and 7. De Vries (35) reviewed cases with submicroscopic $4 \mathrm{q} 35$-qter deletions and different partial trisomies of other chromosomes. An infant boy with deletion $4 q 34.3 \sim$ qter and inverted duplication of the more proximal segment $4 \mathrm{q}$ has been described with DD, hypotonia, dysmorphism, and congenital heart disease. One pure deletion 4 q35-qter has recently been reported in a boy with MR and schizoaffective disorder (53). The distal deletion 49 found in a baby boy with seizures, genital hypoplasia, and nomal development was shown to be familial and 
possibly represents a variant (54). To the best of our knowledge, pure subtelomenic duplication 4 q35-qter has only been reported as polymorphism (55).

Partial monosomy of the terminal segment of $18 \mathrm{p}$ may be heritable and associated with normal or near nomal phenotype even when the segment $p 11.2$-pter is involved $(56,57)$. It has been suggested that terminal deletions $18 p$ are only associated with MR if the patient shows holoprosencephaly as a result for haploinsufficiency of the HPE4 locus (35). A roughly comparable imbalance as in patient 10 has been reported in a newborn with Wiedemann-Beckwith syndrome (58). A case of monosomy 18p11.23-pter in combination with partial trisomy $16 \mathrm{q}$ was interpreted as familial variant (47). We are not aware of reports of pure segmental trisomy $18 \mathrm{p} 11.31$-pter.

\section{Partial Deletion 13q, Partial Duplication 20p}

The clinical findings of this boy (patient 11) with der(13)t(13;20)(q34; 13) derived from a patemal translocation, have been published previously (59). In. brief, he presented with severe developmental and growth retardation, hypospadia, scoliosis, and facial dysmorphism including unilateral ptosis (Fig. 1). Several translocation carriers, but no other family members with an unbalanced karyotype, were identified subsequently.

\section{Partial Deletion 189, Partial Duplication $16 q$}

Patients 12 and 13, who are sisters, were referred by the pediatric cardiologist for evaluation. Patient 12 had a congenital anomaly of the atrioventricular and semilunar valves with valvular aortic stenosis. Her development was delayed from the beginning and she developed behavioral problems. On clinical examination at 14 years, she had moderate MR, a length of $154 \mathrm{~cm}(-2 \mathrm{SD})$, and a hypotonic, elongated face with a broad nasal bridge, and short palpebral fissures (Fig.2). She showed brachymesophalangism of fingers 4 and 5 bilaterally (Fig.2), and an extreme lordosis of the spine.

Her younger sister (patient 13) was also born with a congenital cardiac valve defect. Furthermore, she had a cleft palate which was surgically corrected. On examination at age 10 years, she had also moderate MR. Her behavior was optimistic and hyperactive. She had a length of $133 \mathrm{~cm}(-2$ SD) and dysmorphic facial features resembling her sister (Fig, 1). Her hands were normal. The family history was negative for MR and congenital anomalies.

Routine chromosome analysis revealed a normal $46, \mathrm{XX}$ karyotype in both sisters, TP showed nomal results in patient 12 , and a $22 \mathrm{q} 11.2$ deletion was excluded. Subsequent subtelomeric chromosome analysis showed an unballanced cryptic translocation between chromosomes 16 and 18 resulting in a partial deletion $18 \mathrm{q} 23$-qter and a partial duplication $16 \mathrm{q} 24.3$-qter in both sisters. The chro- 

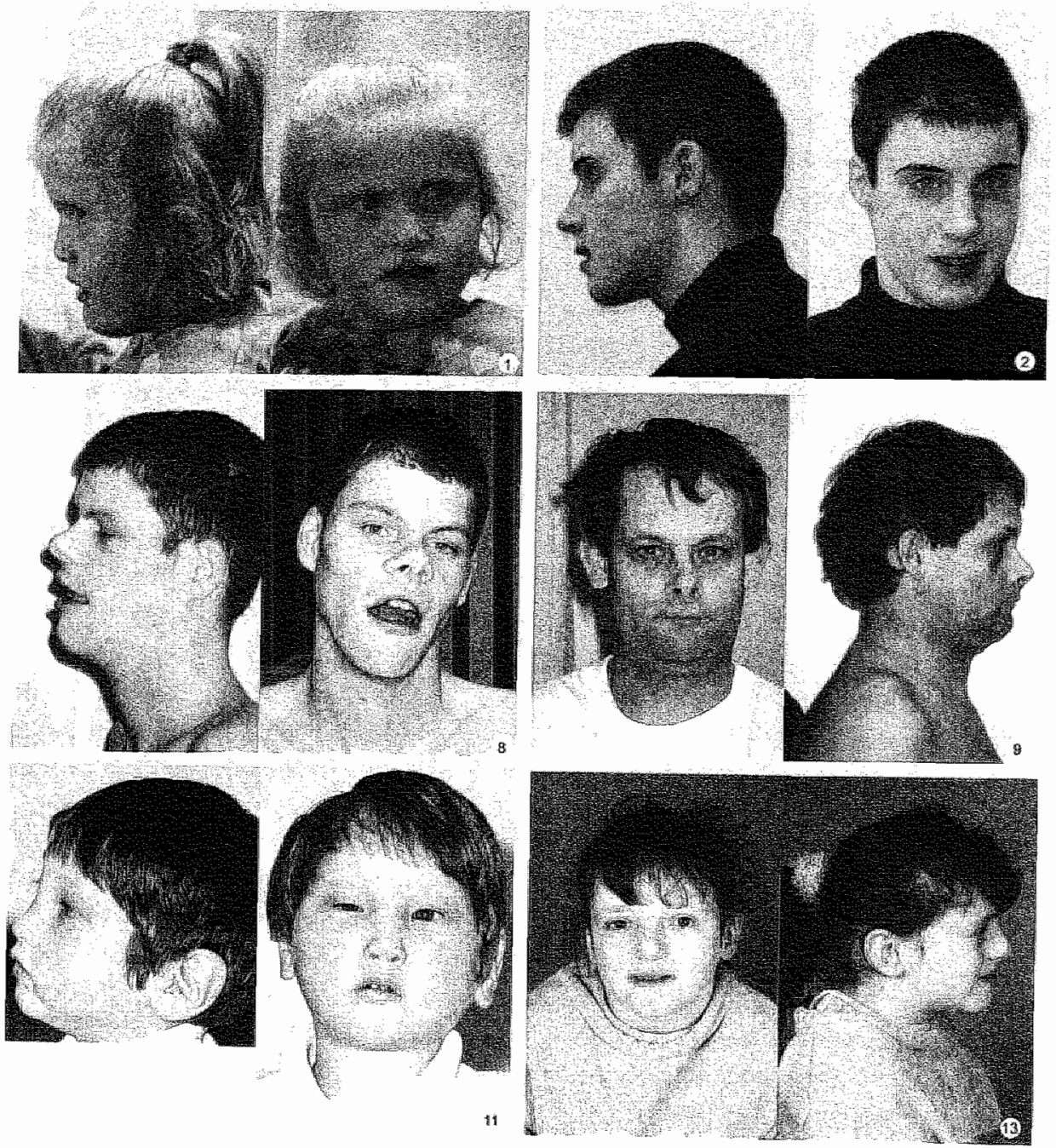

Figure 1: Facial phenotype of 6 patients, all with a subteloneric aberration. The numbers refer to the number of whe patient in Table 1 . 

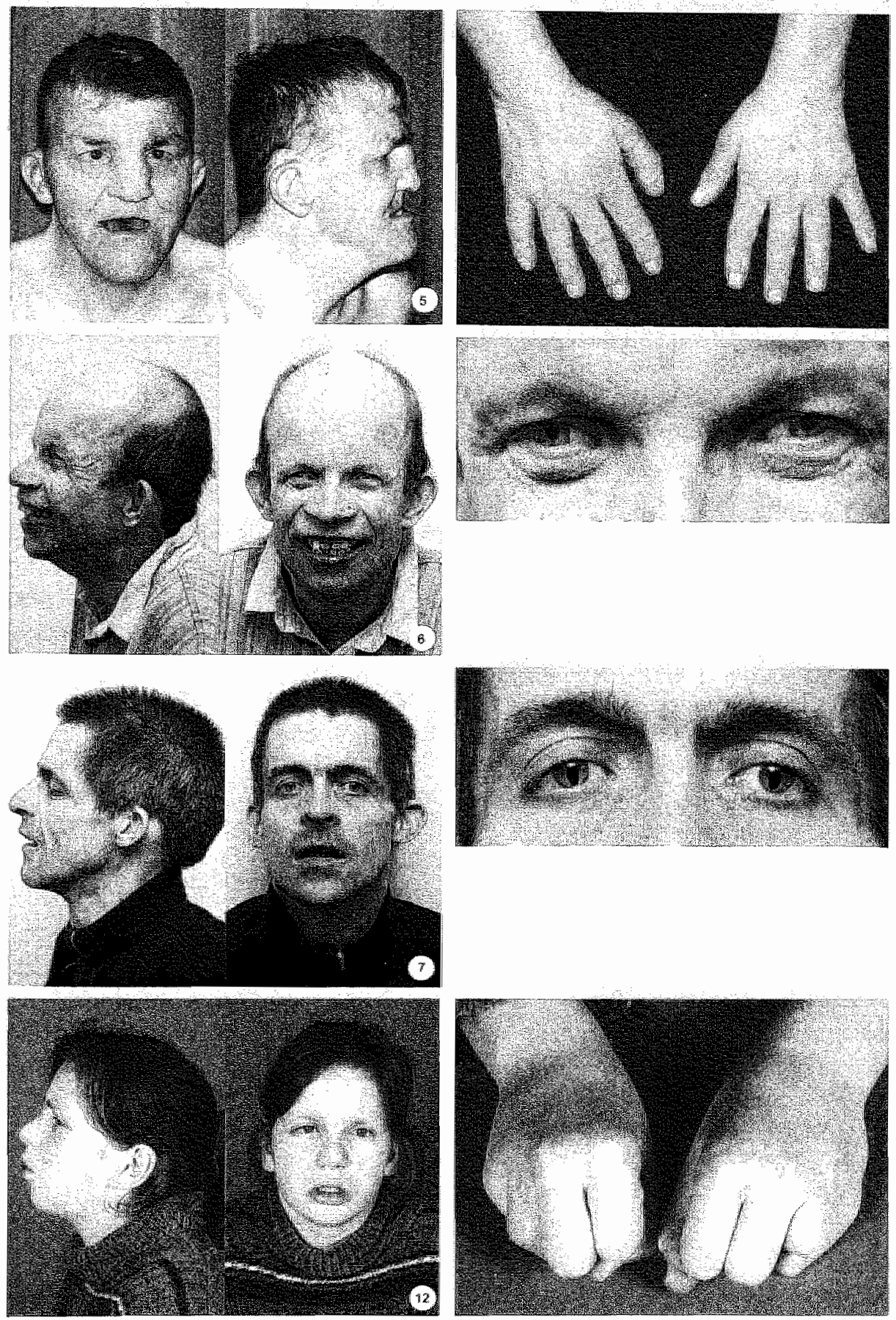

Figure 2: Facial phenotype of 4 patients and hands of patients 5 and 12, all with a subtelomeric alberration. The numbers refer to the number of the patient in Table 1 . 
mosome abnomalities are presumably caused by a cryptic translocation $(16 ; 18)(924.3 ; 923)$ in one of the parents who refused testing.

To the best of our knowledge, there are no other reports of this specific chromosome aberration, Microscopically visible deletions $18 \mathrm{q} 23$-qter have been frequently reported. $\mathrm{MP}$, short stature, microcephaly, ear anomalies, hypertelorism, broad nasal bridge, cleft palate, Jong and tapering fingers, and congenital heart disease are frequent findings (60). Male individuals with $18 \mathrm{q}$ deletion frequently have extemal genital abnormalities. The cardiac defects most commonly reported are VSD, ASD, and pulmonic stenosis (61); in patients 12 and 13, septal defects and specific valuular cardiac anomalies were seen. Kline et al (62) reported hypotonia in all patients examined. Facial hypotonia was also a notable feature in patient 12 . However, the overall clinical picture of terminal deletion $18 \mathrm{q}$ is variable, and a genotype-phenotype correlation could only be established with regand to the head circumference, ear length and thumb abnormallities (63).

Nine patients with trisomy $16 \mathrm{q} 24-\mathrm{qter}$ have been reported with a concomitant small deletion of other chromosome regions in all cases $(47,64-67)$. Brisset et al. (67) concluded in their review that chromosome region $16 \mathrm{q} 24$ could be critical for low birth weight, generalized hypotonia, severe MR, feeding difficulties, distinctive facies with periorbital edema in the newborn period, a high forehead with bitemporal narrowing, multiple vertebral abnormalities, abnormal genitalia, and anal malposition. The only pure distal trisomy $16 \mathrm{q}$, however extending to 16 q23, was reported by Savary et al. (68). The clinical features at 4 months of age consisted of hypotonia, craniofacial dysmorphism differing from patients 12 and 13, thickened gingiva, finger pads and proximal implantation of the first toes.

\section{DISCUSSION}

We report on the clinical presentation of the subtelomeric aberrations found in a study of 161 patients with unexplained DD/MR evaluated by different FISH techniques. As we amed at expanding the knowledge on the phenotype of subtelomeric imbalances and as it has been shown previously that a careful clinical examination and assessment of the family history may lower the yield by TS screening (2), we also included the aberrations found by TP and by TF.

Both the yield of six pathogenic aberrations in the group of 102 patients studied by TS and TP $(5.9 \%)$, and the yield of four pathogenic subtelomeric aberrations found in 89 patients studied by TS ( $4.5 \%$, are approximately consistent with the frequency reported in the literature. $50 \%$ of detected anomalies derived from familial translocations confirming that a family history of $M R$ is a strong indicator for a subtelomeric chromosomal imbalance $(2,20,69)$. In these situations, TP, first 
performed in an obligate carrier, can be the initial method of choice. Its efficiency is confirmed by the detection of translocations in two out of 13 index cases evaluated by TP, although the sample size is too small for statistical conclusions. The sensitivity of TP for the detection of derivative rearrangements is, however, restricted, as has been shown by the evaluation of patient 12 .

A checklist has been proposed to improve the yield of subtelomeric screening and is based on a family history of $\mathrm{MR}$, growth anomalies, dysmorphism and other physical anomalies (70). Meanwhile, there has been criticism about its reliability $(16,18,71)$. Recently, a similar checklist has been published which distinguishes different degrees of MR (27). In our study, two clinically relevant aberrations occurred in patients (patient 2 and 3 ) with a score beneath the respective cut-off of both checklists. In addition, patient 9 would not have been selected for subtelomeric testing according to both scoring lists, although other affected family members would have been selected. We therefore agree with Walter et al. (27) that a checklist, although of vallue for research purposes, constitutes only one aspect in the clinical setting. The overall phenotype, including neurological and behavioral aspects as well as the complete family history, has to be taken into consideration. It is intriguing that $50 \%$ of the 12 patients described with phenotypically relevant subtelomeric imbalances presented with serious behavioral problems.

The diagnosis of a subtelomeric chromosome aberration has immediate impact on counseling, in particular in case of familial rearrangements. Not infrequently, the detection of a cryptic chromosome anomaly leads to revision of a previous 'diagnosis', as has been shown by the history of patients 5, 6,7 and 10. Several factors, however, may hamper counseling on prognosis or on the phenotype that can be expected. Subtelomeric imbalances may be associated with a very variable phenotype, as illustrated by patients 8 and 9 . When a hitherto unreported translocation is found, it may be impossible to deduce the phenotype associated to unbalanced derivatives, from published reports on the respective partial monosomy and trisomy (see for example, patients 8-10). A particular problem is the finding of non-pathogenic variants which has been discussed here for terminal deletion 2q. Recently developed technologies as MAPH, MLPA, and microarray-based CGH are fast and high-throughput methods with high resolution, but the interpretation of results is complicated by a growing number of copy number polymorphisms $(22,23,72)$. It has been suggested that the use of a 'molecular ruler' may give important information on telomeric imbalances by defining the size of the segment of imbalance, and better predicting the phenotype (73). This has been applied to patients 1-4, helping establishing further genotypephenotype correlations. So far, an aberration, deletion or duplication, is considered pathogenic when it occurred de novo or was inherited from clinically similarly affected parents. However, the lack of accessibility of family nembers for 
testing, the incomplete penetrance, and the clinical variability of chromosomal abnomalities are possibly complicating factors. In this context, further reports of the clinical presentation of suble chromosomal imbalances will be of great value.

\section{ACKNOWLEDGEMENT}

We thank the patients and their families for their cooperation and Francis van der Lubbe, Maastricht, for expert photographic assistance.

\section{REFERENCES}

1. Wilkie $A O$. Detection of cryptic chromosomal abnomalities in unexplained mentall retardation: a general strategy using hypervariable subtelomeric DNA polymorphisms. Am J Hum Ganet 1993: 53: 688-701.

2. Riegel M, Bammer A, Jamar M et al. Submicroscopic teminal deletions and duplications in retarded patients with unclassified malformation syndromes. Hum Genet 2001: 109: 286-294.

3. Biesecker $L$. The end of the beginning of chromosome ends. Am J Med Genet 2002: 107: 263-266.

4. Xu J, Chen Z. Advances in molecular cytogenetics for the evaluation of mental retard $x$ tion. Am J Med Genet 2003: 117C: 15-24.

5. Lee $\mathrm{C}$, Gisselsson D, Jin C et al. Limitations of chromosome classification by multicolor karyotyping. Am J Hum Genet 2001: 68: 1043-1047.

6. Ness GO, Lybrek $\mathrm{H}$, Honge $\mathrm{G}$. Usefulness of high-resolution comparative genomic lvybridization (CGH) for derecting and characterizing constitutional chromosome abnomalities. Am J Med Genet 2002: 113: 125-136.

7. Kirch hoff M, Pedersen $\mathrm{S}$, Kjeldsen E et al. Prospective study comparing HR-CGH and subtelomeric FISH for investigation of individuals with mental retardation and dysmorphic features and an update of a study using only HR-CGH. Am J Med Genet 2004: 127A: 11:1-117.

8. Schoumans J, Nielsen. K. Jeppesen I et all. A comparison of different metaphase CGH methods for the detection of cryptic chromosome aberrations of defined size. Eur J Hum Genet 2004: 12: 447-454.

9. Veltonan JA, Schoennakers EFPM, Eussen BH et al. High-throughput anallysis of subtelomeric chromosome rearrangements by use of array-based comparative genomic hybridization. Am J Hum Genet 2002: 70: 1269-1276.

10. Harada $N$, Hatchwell $E$, Okamoto $N$ et al. Subtelomere specific microarray based comparative genomic hybridisation: a rapid detection system for cryptic rearrangements in idiopathic mental retardation. J Med Genet 2004: 41: 130-136. 
11. BallifBC, Kashork CD, Shaffer LG. The promise and pitalls of telomere region-specific probes. Am J Hum Genet 2000: 67: 1356-1359.

12. Van Buggenhout G], van Ravenswaaj-Arts $C$, Mieloo $H$ et al. Dysmorphology and mental retardation: molecular cytogenetic studies in dysmorphic mantally retarded patients. Ann Genet 2001:" 44: 89-92.

13. Rosenberg MJ, Killoran C, Dziadzio L et al. Scanning for telomeric deletions and duplications and uniparental disony using genetic markers in 120 children with malformations. Hum Genet 2001: 109: 311-318.

14. Dawson AJ, Putnam S, Schultz J et al. Cryptic chromosome rearrangements detected by subtelomere assay in patients with mental retardation and dsymorphic features. Clin Genet 2002: 62: 488-494.

15. Hëlias-Rodzewicz Z, Bocian E, Stankiewicz P et al. Subtelomeric rearrangenents detected by FISH in three of 33 families with idiopathic mental retandation and minor physical anomalies. J Med Genet 2002: 39: e53.

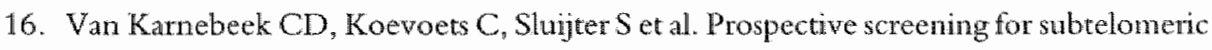
rearrangements in children with mental retardation of unknown aetiology: the Amsterdam experience. J Med Genet 2002: 39: 546-553.

17. Rio M, Molinari F, Heuertz $S$ et al. Automated fluorescent genotyping detects $10 \%$ of cryptic subtelomeric rearrangements in idiopathic syndromic mental retardation. J Med Genet 2002: 39: 266-270.

18. Spranger $S$, Mehl B, Wagner $M$ et al. Subtelomeric screening in clinical practice. Med Genet 2002: 14: A251.

19. Hulley BJ, Hummel M, Wenger SL. Screening for cryptic chromosomal abnormalities in patients with mental retardation and dysmorphic facial features using telomere FISH probes. Am J Med Genet 2003" 117A: 302-303.

20. Bocian E, Helias-Rodzewicz Z, Suchenek K et al. Subtelomeric rearrangements: results from FISFI studies in 84 families with idiopathic mental retardation. Med Sci Monit 2004: 10: CR 143-151.

21. Font-Montgomery $\mathrm{E}$, Weaver DD, Walsh $\mathrm{L}$ et al. Clinical and cytogenetic manifestations of subtelomeric aberations report of six cases. Birth Defects Res Pat A Clin Mol Teratol 2004: 70: 408-415.

22. Koolen DA, Nillesen WM, Versteeg MH et al. Screening for subtelomeric tearrangements in 210 patients with unexplained mental retardation using multiplex ligation dependent probe amplification (MLPA) J Med Genet 2004: 41: 892-899

23. Kriek M, White SI, Bouma MC et al. Genomic imbalances in mental tetardation. I Med Genet 2004: 41: 249-255.

24. Novelli $A_{s}$ Ceccarini $C$, Bernardini $L$ et al. High frequency of subteloneric rearrangements in a cohort of 92 patients with severe mental retardation and dysmorphism. Clin Genet 2004: 66: 30-38.

25. Rodriguez-Revenga $L$, Badenas $C$, Sanchez $A$ et al. Cryptic chromosomal reamangement screening in 30 patients with mental retardation and dysmorphic features. Clin Genet 2004: 65: 17-23. 


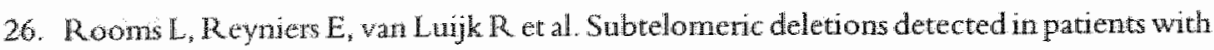
idiopathic mental retardation asing multiplex ligation-dependent probe amplification (MLPA). Hum Mutat 2004: 23:17-21.

27. Walter $\$$, Sandig K, Hinkel GKet al Subtelomere FISH in 50 children with mental retardation and minor anomalies, identified by a checklist, detects 10 rearrangemenes including a de novo ballanced translocation of chromosomes $17 \mathrm{p} 13.3$ and $20 \mathrm{q} 13.33 . \mathrm{Am}$ J Med Gener 2004: 128A: 364-373.

28. Anderlid $\mathrm{BM}$, Schoumans $\mathrm{J}$, Annerến $\mathrm{G}$ et al. Subtelomeric rearrangements detected in patients with idiopathic mental retardation. Am J Med Genet 2002: 107: 275-284.

29. Lichter $P$, Cremer $T$, Borden J et al Delineation of indiwidual human chromosomes in netaphase and interphase cells by in situ suppression hybridization using recombinant DNA libraries. Hum Genet 1988: 80: 224-234.

30. Heilistedt HA, Ballif BC, Howand LA et al. Population data suggest that deletions of 1 p36 are a relatively common chromosome abnomality. Clin Genet 2003a: 64: 310-316.

31. Slavotinek A, Shaffer LG, Shapira SK. Monosomy 1p36. J Med Genet 1999: 36: 657-663.

32. Heilstedt HA, Ballif BC, Howard LA et al. Physical map of $1 \mathrm{p} 36$, placement of breakpoints in monosomy $1 \mathrm{p} 36$, and clinical characterization of the syndrome. Am $\mathrm{J}$ Hum Genet 2003b: 72: 1200-1212,

33. Shapira SK, MCCaskill C, Northrup H et al. Chromosome $1 p 36$ deletions: the dinical phenotype and molecular characterization of a common newly delineated syndrome. Am J Hum Genet 1997: 61: 642-650.

34. Giraudeau F, Taine $L$, Biancalana $V$ et al. Use of a set of highly polymorphic minisatellite probes for the identification of cryptic 1 p 36.3 deletions in a large collection of patients with idiopathic mental retardation. J Med Genet 2001: 38: 121-125.

35. De Vries BB, Winter $\mathbb{R}$, Schinzel $A$, van $\mathbb{R}$ avenswaaij-Arts $C$. Telomeres: a diagnosis at the end of the chromosomes. I Med Genet 2003: 40: 385-398.

36. Knight-Jones E, Knight $S$, Heussler $H$ et al. Neurodevelopmental profle of a new dysmorphic syndrome associated with submicroscopic partial deletion of 1 p36.3. Dev Med Child Neurol 2000: 42: 201-206.

37. Redon R, Rio M. Gregory SG et all. Tiling path resolution mapping of constitutional. 1 p36 deletions by array- $\mathrm{CGH}$ : contiguous gene delevion or "deletion with positional affect" syndrome? J Med Gener 2005: 42: 166-171.

38. Fan $Y S$, Zhang $Y$, Speevak $M$ et al. Detection of submicroscopic aberrations in patients with unexplained mental retardation by fuorescence in situ hybridization using multiple subtelomeric probes. Gener Med 2001: 3: 416-421.

39. Aldred MA, Sanford RO. Thomas NS et al. Molecular analysis of 20 patients with $2 q_{37.3}$ monosony: definition of minimm deletion intervals for key phenotypes. I Med Genet 2004: 41: 433-439.

40. Chassaing N, De Mas P. Tauber M et al. Molecular characterization of a cryptic $2 \mathrm{q} 37$ deletion in a patient with Albright hereditary osteodystrophy-like phenotype. An J Med Genet 2004: 128A: 410-413. 
41. Bijlsma EK, Aalfs CM, Sluitjer $S$ er al. Familial cryptic translocation between chromosomes 2qter and 8qter: further delineation of the Albright hereditary osteodystrophy-like phenotype. J Med Genet 1999: 36:604-609.

42. Wilson LC, Leverton K, Oude Lutrikhuis MEM et al. Brachydactyly and mental retardation: an Albright hereditary osteodystrophy-like syndrome localized to 2q,37. An J Hum Genet 1995: 56: 400-407.

43. Shrimpton AE, Braddock BR, Thomson LL et al. Molecullar dellineation of deletions on 2 37.3 in three cases with an Abright hereditary osteodystrophy-like phenotype. Clin. Genet 2004: 66: 537-544.

44. Giardino D, Finelli $\mathbb{P}$, Gottardi $G$ et al. Narrowing the candidate region of Albright hereditary osteodystrophy-like syndrome by deletion mapping in a patient with an unbalanced cryptic translocation $\mathrm{t}(2 ; 6)(\mathrm{q} 37.3 ; \mathrm{q} 26)$. Am J Med Genet 2003: 1.22A: 261-265.

45. Lukusa $T$, Vermeesch JR, Holvoet $M$ et al. Deletion $2 q 37.3$ and autism: molecular cytogenetic mapping of the candidate region for autistic disorder. Genet Counsel 2004: 15: 293-301.

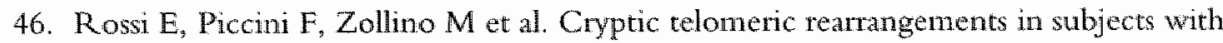
mental retardation associated with dysmorphism and congenital malformations. J Med Genet 2001: 38: 417-420.

47. Roberts AE, Cox GF, Kimonis $V$ et al. Clinical presentation of 13 patients with subtellomeric rearrangements and a review of the literature. Am J Med Genet 2004: 128A: 352-363.

48. Syrrou M, Keymolen $K$, Devriendt $K$ et al. Gilypican 1 gene: good candidate for brachydactyly type E. Am J Med Genet 2002: 108: 310-314.

49. Irving $M$. Hanson $H$, Turnpenny $P$ et al. Deletion of the distal long arm of chromosome 10; is there a characteristic phenotype? A report of 15 de novo and familial cases. Am J Med Genet 2003: 123A: 153-163.

50. Scigliano S, Gregoire MJ, Schmitt M et al. Terminal deletion of the long arm of chromosome 10. Clin Genet 2004: 65: 294-298.

51. Lukusa $T$, Fryns JP. Pure distall monosony $10 q 26$ in a patient displaying clinical features of Prader-Willi syndrome during infancy and distinct behavioural phenotype an adolescence. Genet Counsel 2000: 11: 119-126.

52. Moog U, Engelen JJM, van Schrojenstein Lantman-de Valk HMJ et al. Familial cryptic translocation with deletion $4 \mathrm{q} 33->4$ qter and duplication $7 \mathrm{q} 34->7 \mathrm{qter}$ in brothers with mental retardation, macrocephaly and iriscoloboma. Clin Dysmorphol 2003: 12:35-39.

53. Pickard BS, Hollox EJ, Malloy MP et al. A $4 \mathrm{q} 35.2$ subtelomeric deletion identified in a screen of patients with co-morbid psychiatric illness and mental retardation. BMC Med Genet 2004: 5: 21 .

54. Tupler R, Berardinelli $A$, Barbierato $L$ et al. Monosomy of distal $4 q$ does not cause facioscapulohumeral muscular dystrophy. J Med Genet 1996: 33: 366-370.

55. Hengstschläger $M$, Prusa $A$, Repa $C$ et al. Subtelomeric rearrangements as neutral genomic polymorphisms. An I Med Genet 2005: 133A: 48-52. 
56. Rugola MA, Plaja A, Mediano C et al. Characterization of a heritable partial monosomy $18 \mathrm{p}$ by molecular and cytogenetic analysis. An J Med Genet 2001: 104: $37-41$.

57. Tsukahara M, Imaizum K, Fujita K at al. Familial Del(18p) syndrome. Am J Med Genet 2001: 99:67-69.

58. Fryns JP, Kleczkowska $A_{,}$Devriendt $K$ etal. Wiedemann-Beckwith syndrome and chromosomal duplication 4q/deficiency 18p. Genet Couns 1993: 4:37-41.

59. De Die-Smulders CEM, Engellen JJM, Albrechts JCM, Hamers GJH. Detection of a cryptic translocation $t(13 ; 20)(q 34 ; \mathrm{p} 13)$ in an unexplained case of MCA/MR: walue of FISH over high resolution banding. Am J Med Genet 1999: 86: 385-388.

60. Jones KL. Smith"s Recognizable Patterns of Human Malformation. Philadelphia: WB Saunders, 1997.

61. Cody JD, Ghidoni PD, DuPont BR et al. Congenital anomalies and anthropometry of 42 individuals with deletions of chromosome 18q. Am J Med Genet 1999: 85: 455-462.

62. Kline $A D$, White $M E$, Wapner $R$ et al. Molecular analysis of the $18 \mathrm{q}$ - syndrome and correlation with phenotype. An J Hum Genet 1993: 52: 895-903.

63. Maiwald R, Overhauser J, Laccone F. No evidence for imprinting in distal $18 \mathrm{q}$. J Med Genet 2000: 37: 152-156.

64. Hahm SY, Chitayat D, Iqbal MA et al. Partial duplication 16q: report of two affected siblings resulting from maternal translocation and literature review. Clin Genet 1987:31: $343-348$.

65. Maher ER, Willatt $\mathrm{L}$, Cuthbert $\mathrm{G}$ et al. Three cases of $16 \mathrm{q}$ duplication. J Med Genet 1991: 28: 801-802.

66. Giardino D, Finelli $P$, Gottardi $G$ et al. Cryptic subtelomeric translocation $t(2 ; 16)(q 37 ; \mathrm{q} 24)$ segregating in a family with unexplained stillbirths and a dysmorphic, slightly retarded child. Eur J Hum Genet 2001: 9: 881-886.

67. Brisset $S$, Joly $G$, Ozillon $C$ et al. Molecular characterization of partial trisomy $16 q 24.1-$ qter: clinical report and review of the literature. Am J Med Genet 2002: 113:339-345.

68. Savary JB, Vassuer F, Manouvrier $S$ et al. Trisomy $16 q 23->$ qter arising from a maternal $t(13 ; 16)(\mathrm{p} 12 ; \mathrm{q} 23)$ : case report and evidence of the reciprocal balanced maternal rearrangement by the Ag-NOR technique. Hum Genet 1991: 88: 115-118.

69. Knight SJ, Regan R, Nicod A et al. Subtle chromosomal rearrangements in children with unexplained mental retardation. Lancet 1999: 354: 1676-1681.

70. De Vries BB, White SM, Knight SJ et al Clinical studies on submicroscopic subtelomeric rearrangements: a checklist. J Med Genet 2001: 38: 145-150.

71. Baker E, Hinton L, Callen DF et al Study of 250 drildren with idiopathic mental retardation reveals nine cryptic and diverse subtelomeric chromosome anomalies. Am J Med Genet 2002: 107: 285-293.

72. Oostlander AE, Meijer GA, Ylstra B. Microarray-based comparative genomic hybridization and its applications in human genetics. Clin Genet 2004: 66: 488-495.

73. Martin CL, Waggoner DJ, Wong A et al. "Molecular rulers" for calibrating phenotypic effects of telomere imbalance. J Med Genet. 2002: 39: 734-740. 


\subsection{PREVALENCE OF CYTOGENETIC ABERRATIONS IN MENTAL RETARDATION}

A review of 11 studies, published between 1977 and 1996, indicated a prevalence of $4 \%-28 \%$ of clinically relevant chromosome aberrations in mentally retarded people (Curry et al., 1997). In 2003, Xu and Chen extended the review by including five further studies published between 1998-2000, and calculated a prevalence of $4 \%-34 \%$ with a mean of $16.1 \%$ (Xu and Chen, 2003). In the same year, Shevell et al. reviewed six studies performed in a pediatric population, five of which were not quoted in the review by $\mathrm{Xu}$ and Chen; they found a range of $2.9 \%-11.6 \%$ of chromosomal aberrations, with a mean prevalence of $3.7 \%$. In an extensive literature review, Van Karnebeek et all. found a mean of $9.5 \%$ of chromosome aberrations in MR, varying from $4.1 \%$ in individuals with borderline or mild MR, to $13.3 \%$ in persons with moderate to profound MR (van Karnebeek et al., 2005). All these data addressed chromosome anomalies detectable by classical cytogenetic investigations; the most frequent of these chromosome anomalies is trisomy 21 (Down syndrome). The aforementioned mean frequency of $5.2 \%$ for subtelomeric rearrangements thus has to be added to the other figures. The wide ranges in the different surveys are due to differences in patient ascertainment criteria, to differences in the degree of $M R$ and in the presence of physical anomalies, and to differences in cytogenetic facilities. However, (very) roughly it can be concluded that one in 10 people with MR has a cytogenetically visible chromosome anomaly, and that one in 20 individuals a cryptic subtelomeric aberration explaining the MR. Chromosome anomalies thus are the most frequent genetic cause of MR. Because of this, every individual with unexplained MR should have a chromosome investigation.

\section{REFERENCES}

Curry CJ, Stevenson RE, Aughton D, Byrne J, Carey JC, Cassidy S, CunniffC, Grahan JM Jr, Jones MC, Kaback MM, Moeschler J。 Schaefer GB, Schwartz S, Tarleton J, Opitz J. 1997. Evaluation of mental retardation: recommendations of a consensus conference. Am J Med Genet 72:468-477.

Shevell M, Ashwal S, Donley D, Flint J, Gingold M, Hirtz D, Majnemer A, Noetzel M, Sheth RD. 2003. Practice parameter: evaluation of the child with global developmentall delay: report of the Quality Standards Subcommittee of the American Academy of Neturology and The Practice Committee of the Child Neurology Society. Neurology 60:367-380.

Van Karnebeek CD, Jansweijer MC, Leenders AG, Offringa M, Hennekanu R C. 2005. Diagnostic investigations in individuals with mental retardation: a systematic literature review of their usefulness. Eur J Hum Genet 13:6-25.

$\mathrm{XuJ}$, Chen Z. 2003. Advances in molecular cytogenetics for the evaluation of mental retardation. Am J Med Genet 117C:15-24. 


\section{MOLECULAR STUDIES}

5.1 X-linked and autosomal forms of mental retardation diagnosed by molecular investigation

5.1.1 Fragile X syndrome 104

5.1.2 X-linked mental retardation syndromes other than Fragile X syndrome 105

5.1.3 Syndromic and non-syndromic X-linked mental retardation 107

5.1.2 Autosomal forms of mental retardation $\quad 109$

5.2 MECP2 related disorders in male patients

5.2.1 Neurodevelopmental disorders in males related to the gene causing Rett syndrome in females (MECP2) Eur J Paed Neurol 2003;07:5-12 (Review) 117

5.2.2 MECP2 mutations are an infrequent cause of mental retardation associated with neurological problems in male patients

Submitted 133 


\subsection{1:FRAGILE X SYMDROME}

Since a long time, it has been known that there is a male excess among patients with MR (Penrose, 1938; Lehrke, 1968). The overall male to female ratio is approximately $1.4: 1$ and is more pronounced for mild than for severe $M R$ (Hamel, 1999). The predominance of males among mentally retarded individuals. has stimulated the search for genes on the $\mathrm{X}$-chromosome. These $\mathrm{X}$-linked forms ofMR could affect approximately 1 in $550-600$ males, and about 1 in 400 females could be a carrier (Hamel \& Poppelaars, 2000).

Fragile $X$ syndrome was the first specific $X$-linked disorder causing $M R$ that became widely known. Since the initial report by Martin and Bell (1943), followed by the report by Lubs of the "marker $X$ " (1969), and the rediscovery of this syndrome in the 1970 , the characteristics of fragile $X$ syndrome have been well and abundantly delineated. For a review, the reader is referred to the paper by de Vries et al. (1998). In brief, the phenotype of affected males is characterized by MR, a characteristic personality and shy behavior with lack of eye-contact, hyperactivity, hand-flapping, and echolalic speech; and physical findings which include relative macrocephaly, an elongated face, large protruding ears, smooth skin and macro-orchidism. All of these phenotype characteristics are variable and may be influenced by ethnic differences. The name "fragile $X$ " derives from the observation of an abnomal $X$-chromosome with a fragile site at terminal $\mathrm{Xq}$ when using a folic acid depleted medium (Sutherland, 1977). This cytogenetic abnomality was used for Fragile $X$ analysis until the discovery of the gene.

The gene responsible for fragile $X$ syndrome is located at $X q 27.3$ and was identified in 1991 by different groups (Verkerk et al., 1991; Yu et al., 1991; Oberle et al., 1991) and called FMR / (Fragile X Mental Retardation 1) gene. Fragile X syndrome was the first disonder known to be caused by the expansion of a trinucleotide repeat ("dymamic mutation'). Meanwhile, at least 13 other neurological, predominantly neurodegenerative disorders ate known to be caused by the same mechanism, including Huntington's disease, Myotonic Dystrophy, and several types of Spinocerebellar Ataxias (Costa Lima \& Pimentel, 2004). The $F M R 1$ gene has a repeated CGG triplet in its first exon, which varies in the normal population from 6 to 54 repeats. Fragile $X$ syndrome is associated with instability and subsequent expansion of repeats. On the basis of the number of repeats, a premutation ( 43 to 200 repeats) and a full mutation ( $>200$ repeats) can be distinguished. Repeats between 43 and 54 are often referred to as intermediate alleles, and can be transmitted stably or behave as a premutation. Generally, a premutation is not associated with MR, but it may be the cause of premature ovarian failure in females or midlife movement disorders (FXTAS, Fragile X-associated Tremor/Ataxia Syndrome), particularly in male carriers (Sherman, 2000; 
Hagerman \& Hagerman, 2004a; Hagerman \& Hagerman, 2004b). It may be transmitted to the next generation stably or, when transmitted by a woman, in an expanded state, e.g. as a full mutation. A full mutation leads to repression of transciption of the FMR 1 gene due to an abnormally methylated CGG stretch, and thus to the lack of the normally encoded protein FMRP (for review of the FMR1 gene and its function see Oostra \& Chiurazzi, 2001). Clinically, males with a full mutation have fragile $X$ syndrome with $M R$ as major feature. About $50 \%$ of females carrying a full mutation are also mentally retarded, although to a lesser and more variable degree than males.

Fragile $\mathrm{X}$ syndrome is recognized as the most common monogenetic cause of MR. Prevalence estimates range between the initially presumed prevalence of about 1 in 1500 males and 1 in 2500 females (Warren \& Nelson, 1994), to 1 in 6000 males established some years later in the Netherlands (de Vries et al., 1997). Most probably, the general prevalence for males is close to $1 \mathrm{in} 4000$ (Stevenson \& Schwartz, 2002). Because of its high prevalence, and its implications for patient management and family counselling, given also the variability of the phenotype, in particular in female patients, FMR 1 testing should be strongly considered in all males and females with unexplained MR (Curry et al., 1997). DNA analysis of the FMR 1 gene is reliable, and indicated even in the absence of a positive family history. Microcephaly can be considered as exclusion criterium in male patients (de Vries et al., 1999). Checklists to evaluate which patients should be tested have been set up by Giangreco et al. (1996) for the pediatric and by de Vries etal. (1999) for both the pediatric and adult male population. These score for MR, (facial) phenotype, family history, and personality and behavior. Preselection with these checklists allows exclusion from testing in $60 \%$ and $86 \%$, respectively. Future studies are yet needed to confirm the sensitivity of the scoring systems.

Following the discovery of fragile $X$ syndrome, a growing list of $X$-linked MR syndromes has been identified, and also the number of autosomal forms of MR syndromes has increased steadily. In january 2005, the OMIM (Online Mendelian Inheritance in Man) catalog registered more than 1000 entries in which MR is a major or possibly associated feature. Most of these syndromes are rare, and/or only a (smail) proportion of patients has MR. Some clinically relevant syndromes with MR as a major feature will be briefly presented here.

\subsubsection{X-LINKED MR SYNDROMES OTHER THAN FRAGILE $X$ SYNDROME}

At present, in total 140 XLMR syndromes have been delineated, based on the clinical presentation. In 66 , the responsible gene has been identified, and in addi- 
tion, $50 \mathrm{X}$-chromosomal regions have been mapped but no pathogenic gene mutation has yet been identified (Ropers and Hamel, 2005; www.ggc.org/xlmr.htm; http:/ XLMR interfree.it ). For more clinical information on the syndromes listed below and on X-linked $M R$ in general, the reader is referred in particular to the comprehensive treatise by Stevenson, Schwartz and Schroer (2000) and to the review written by Ropers and Hamel (2005).

Rett syndrome (OMIM \#312750) is a severe neurodevelopmental disorder affecting mostly females. It is an important cause of severe MR in females and has an estimated prevalence of 1 in 10.000 girls at 14 years of age (Kerr, 1992). Diagnostic criteria were set up in the 1980s and revised in 2001. (Hagberg et al., 1985; The Rett Syndrome Diagnostic criteria Work Group, 1988; Hagberg et al., 2002). They focus on a characteristic course with normal initial development, followed by stagnation and regression of motor and mental abilities, loss of acquired skills, in particular purposeful hand-use, deceleration of head-growti, and autonomic failure. Classic and variant forms can be distinguished. The findings in particular in adolescent and adult females have been abundantly described by Smeets et al. $(2003,2005)$. In 1999, mutations in the MECP2 gene have been found to cause Rett syndrome (Amir et al., 1999). They can be found in up to $90 \%$ of females with classic Rett syndrome. The much rarer disorders in male patients associated with MECP2 mutations will be discussed separately (see chapter 5.2).

Coffin-Lowry syndrome (OMIM \#303600), has a well recognizable pattern of somatic features (Lowry et al., 1971; Gilgenkrantz et al., 1988; Hunter, 2002): short stature, hypotonia and joint hypermobility, soft hands with tapering fingers, and a distinctive facies evolving in childhood with hypertelorism, down-slanting palpebral fissures, anteverted nares and full lips (for review see Hanauer \& Young, 2002). Female carriers may be nomal, but often show less pronounced features. Coffin-Lowry syndrome is caused by mutations in the RSK2 gene which maps to Xp22 (Trivier et al., 1996). Mutations are found in less than half of the patients and the condition is considered to be possibly heterogeneous (Zeniou et al., 2002).

XLMR-hypotonic facies syndrome (OMIM \#301040) is caused by mutations in the XNP gene on Xq13 (Gibbons et al., 1995). They cause a spectrum of previously clinically delineated syndromes, inluding ATRX ( $\alpha$-thalassemia mental retardation) syndrome (Yntema et al., 2002; Abidi et al., 2003). The core phenotype of the whole spectrum consists of severe MR, hypotonia and in particular a hypotonic face possibly associated with growth impairment, genital anomalies and distinctive craniofacial features with microcephaly, hypertelorism, a small nose with anteverted nares, and a carpe-like, open mouth with prominent lips. DNA analysis is hampered by the great size and the complex organization of the 
gene, and can be preceeded by a screening test for themoglobin inclusions in erythrocytes.

All three syndromes are chromatin remodelling disorders (for review see Ausio et al., 2003), meaning that mutations in these genes cause changes of the package of DNA into chromatin which lead to a gemeral deregulation of transcription. Another chromatin remodelling disorder is Rubinstein-Taybi syndrome (see 5.1.4, Table II): the CREBBP protein is activated by and interacts with $R S K 2$. The ARX gene also contributes significantly to XLMR (Stromme et al, 2002; Stevenson and Schwartz, 2002; Mandel \& Chelly, 2004). It directs neuronal proliferation, differentiation and migration within the forebrain. Different disorders are associated with this gene. $X$-linked lissencephaly with abnormal genitalia (XLAG) is caused by loss-of-function mutations (Kitamura et al., 2002), whereas a recurrent poly-A expansion ( 24 bp duplication), and rarer missense mutations, are associated with MR with dystonia, epilepsy/seizures and other neurological signs, and with X-linked West syndrome (ISSX) (Partington et all, 2004).

All four genes (MECP2, RSK2, XNP and $A R X)$ are also associated with nonspecific MR (see below).

\subsubsection{SYNDROMIC AND NONSYNDROMIC X-LINKED MENTAL RETARDATION}

In the early $1990 \mathrm{~s}$, the syndromic forms of X-linked MR (MRXS) discussed above were distinguished from non-syndromic forms (MRX) which have nonspecific MR as the only sign (for review of both see Chelly \& Mandel, 2001; Stevenson \& Schwartz, 2002; and Ropers \& Hamel, 2005). At present, at least 21 MRX genes have been identified. However, each accounts probably for less than $1 \%$ of MRX cases, with the exception of $A R X$ mutations, which have a higher frequency in familial MRX (Mandel \& Chelly, 2004). The prevalence of JARIDIC mutations and of PQPB1 mutations, which both cause nonsyndromic and syndromic forms of MR, has not yet been established. According to first reports, these may also be high-prevalence contributors to XLMR (Kalscheuer et al., 2003; Lenski et al., 2004, Jensen et al., 2005).

In the pathogenesis of $\mathrm{MR}$, aberrant $\mathrm{Rho}$ signaling plays an important role. Rho proteins (Rho GTPases) form a subgroup of the Ras superfamily of small GTPbinding proteins. They regulate the actin cytoskeleton in neurons, neurite outgrowth and branching, and synaptic connectivity (Ramakers, 2000; Ramakers, 2002). Several MRX genes have been shown to be involved in Rhosignaling, three of which (OPHN1, PAK3, ARHGEF6) participate directly in cellular signaling through RhoGTPases (Ramakers, 2002). It is intriguing to speculate that polymorphisms and mutations in Rho-linked genes ma also 
Table 5.I: X-linked genes causing syndromic (MRXS) and non-syndromic (MRX) MR

\begin{tabular}{|c|c|c|c|}
\hline $\begin{array}{l}\text { Gene } \\
\text { (OMMM) }\end{array}$ & Locus & MRXS & Reference \\
\hline $\begin{array}{l}\text { FGD } \\
(305400)\end{array}$ & $X p 11.21$ & Aarskog-Scott syndrome & Orrico et all. 2004 \\
\hline $\begin{array}{l}\text { MRDDIC } \\
(314690)\end{array}$ & $x p 11.23$ & $\begin{array}{l}\text { MR and microcephaly, possibly with spastio } \\
\text { paraplegia, seizures, hypotonic face } a / 0 \\
\text { short stature }\end{array}$ & cjensen et al. 2005 \\
\hline $\begin{array}{l}\text { PQPB } \\
(300463)\end{array}$ & $x p 11.23$ & Renpenxing syndrome & Stevenson et al. 2005 \\
\hline $\begin{array}{l}\text { RSK2 } \\
(300075)\end{array}$ & $X_{p} 22.1-p 22.2$ & Coffin-Lowry syndrome & $\begin{array}{l}\text { Trivier et al. } 1996 \\
\text { Zeniou et al. } 2002\end{array}$ \\
\hline $\begin{array}{l}A R X \\
(300382)\end{array}$ & $\mathrm{xp} 22.13$ & $\begin{array}{l}\text { X-linked lissencephaly with abnormal } \\
\text { genitalia; X-linked West sydrome; } M R \\
\text { with dystonia a/o seizures }\end{array}$ & $\begin{array}{l}\text { Stronme et al. } 2002 \\
\text { Frints et al. } 2002 \\
\text { Partington et al. } 2004\end{array}$ \\
\hline $\begin{array}{l}\text { OPHN1 } \\
(300127)\end{array}$ & $\mathrm{xq} 12$ & $\begin{array}{l}\text { MR, cerebellar hypoplasia, hypotonia, } \\
\text { seizures }\end{array}$ & $\begin{array}{l}\text { Billuart et al. } 1998 \\
\text { Philip et al. } 2003\end{array}$ \\
\hline $\begin{array}{l}X N P \\
(300032)\end{array}$ & $\mathrm{Xg} 13$ & XLMR-hypotonic facies syndrome & Gibbons et al. 1995 \\
\hline $\begin{array}{l}\text { ACTR } \\
(300034)\end{array}$ & $x_{q} 22-q 23$ & MR, seizures & $\begin{array}{l}\text { Vervoort et al. } 2002 \\
\text { Bienvenu et al. } 2003\end{array}$ \\
\hline $\begin{array}{l}M E C P 2 \\
(300005)\end{array}$ & $\mathrm{Xq} 28$ & $\begin{array}{l}\text { Rett syndrome; different } \\
\text { neurodevelopmental disorders in males* }\end{array}$ & $\begin{array}{l}\text { Amir et al. } 1999 \\
\text { Miltenberger-Miltenyi \& } \\
\text { Laccone } 2003 \\
\text { Moog et al. } 2003\end{array}$ \\
\hline $\begin{array}{l}\text { SLC6A8 } \\
(300036)\end{array}$ & $x, 28$ & Creatine deficiency syndrome & Salonons et all 2003 \\
\hline
\end{tabular}

* see chapter 5.2

contribute to the natural variance of cognitive functioning in general, and to high cognitive functioning (Ramakers, 2002).

The distinction between MRX and MRXS has become less clear since it became known during the last years, that mutations in several $X$-linked genes can result in both MRX and MRXS. To date, at least 10 genes are known causing syndromal and nonsyndromal MR (see Table 5.I). The different expression may partly be explained by the different locations and/or type of mutations or different effects on splicing or gene function, as has been shown e.g. for the FGDI and ARX gene. These factors result in interfamilial variability. However, disorders related to 
mutations in several genes, e.g. XNP, RSK2, ARX, show both inter-and infrafamilial variability. The expression may also be influenced by an alternative mode of translation initiation, as recently shown for the XNP gene (Howard et al., 2004), or by other epigenetic, genetic or environmental modifiers (Stevenson \& Schwartz, 2004). In order to illustrate these "vanishing boundaries between nonspecific and syndromic forms of X-linked MR" (Frints et al., 2002), the phenotypic effects of $M E C P 2$ mutations in male patients will be discussed in the chapter 5.2 .

So far, it can be concluded that probably 100 - 150 genes for $X$-linked MR may exist which constitute $10-12 \%$ of all genes involved in MR. Of these, about $50 \%$ have been identified. At least 10 genes may produce syndromic and nonsyndromic XLMR. Additional research is still needed, e.g. on genotype-phenotype correlation and in particular to identify other modifiers of gene expression.

\subsubsection{AUTOSOMAL FORMS OF MENTAL RETARDATION DIAGNOSED BY MOLECULAR INVESTIGATION}

Table 5.II is a selected list of well-known autosomal MR syndromes which can be confirmed by DNA analysis. Some other syndromes which primarily are identifiable by biochemical screening, will be mentioned in chapter 6 , e.g. Smith-LemliOpitz syndrome, Sanfilippo syndrome and phenylketonuria. All of these, as for $X$-linked syndromes, have in common that, based on a suspicion on clinical grounds, molecular studies are specifically requested for the disorder in question for confirmation of the diagnosis and genetic counselling. This is in contrast to genome analysis by conventional chromosomal studies which are a screening method.

In contrast to the impressive number of syndromic autosomal forms of MR, only very few autosomal forms of non-specific MR have been identified so far. In 2002, the gene encoding neurotrypsin has been found to be involved in autosomal recessive non-specific MR (Molinari et al, 2002). Three further genetic loci have been found for autosomal recessive non-syndromic $\mathrm{MR}$ on chromosomes $3 \mathrm{p}, 4 \mathrm{q}$ and $19 \mathrm{p}$. Sevenal candidate genes for the chromosome $3 \mathrm{p}$ type, designated as MR T2A (OMIM 607417), have been analyzed recently but no mutation has been detected. This suggests that $M R T 2 A$ is not related to homozygous mutations in one of the candidate genes, but to another, as yet unidentified, pathogenetic mechanism (Higgins et al, 2004). The involvement of autosomal genes in MR may be more complex than a model of monogenic inheritance. At present, molecular studies for non-syndromic autosomal forms of MR are irrelevant in daily practice. 
Table 5.II: Selected autowonal dominant MR syndromes

\begin{tabular}{|c|c|c|c|c|c|}
\hline $\begin{array}{l}\text { Syndrome (s) } \\
\text { (OMIM) }\end{array}$ & Features in addition to MR & Locus & Gene & $\begin{array}{l}\text { Molecular } \\
\text { diagmosis }\end{array}$ & $\begin{array}{l}\% \text { of patients } \\
\text { with } M R\end{array}$ \\
\hline $\begin{array}{l}\text { Angelman s } \\
105830 \mathrm{y}\end{array}$ & $\begin{array}{l}\text { Microbrachycephaly, } \\
\text { typical face } \\
\text { Paroxymall laughter } \\
\text { Seizures, ataxia }\end{array}$ & $\begin{array}{l}15 q 11= \\
q 13\end{array}$ & UBE $3 A$ & $80 \% *$ & $100 \%$ \\
\hline $\begin{array}{l}\text { Prader-Willi s: } \\
(176270)\end{array}$ & $\begin{array}{l}\text { Neonatal hypotonia } \\
\text { Short stature } \\
\text { Hyperphagia } \\
\text { Behavioral problems }\end{array}$ & $\begin{array}{l}15 q 11- \\
q 13\end{array}$ & $\cdots$ & $100 \% *$ & $95 \%$ \\
\hline $\begin{array}{l}\text { Noonan s. } \\
(163950)\end{array}$ & $\begin{array}{l}\text { Short stature } \\
\text { Heart defect } \\
\text { Typical Gee }\end{array}$ & $12 q 24.1$ & PTPN1 & $50 \%$ & $15-35 \%$ \\
\hline $\begin{array}{l}\text { Rubinstein- } \\
\text { Taybi s." } \\
\text { (180849) }\end{array}$ & $\begin{array}{l}\text { Growth retardation } \\
\text { Broad thumbs + great toes } \\
\text { Typical face } \\
\text { Heart defect }\end{array}$ & $\begin{array}{l}16 p 13.3 \\
22 q 13.2\end{array}$ & $\begin{array}{l}\text { CREB } \\
\text { EP300 }\end{array}$ & $40^{\circ} * * *$ & Almost $100 \%$ \\
\hline $\begin{array}{l}\text { Myotonic } \\
\text { dystrophy } \\
(160900)\end{array}$ & $\begin{array}{l}\text { Infantille + congenital form: } \\
\text { hypotonia, poor feeding" } \\
\text { weakness }\end{array}$ & $\begin{array}{l}19 \mathrm{q} 13.2 \\
913.3\end{array}$ & DMPK & $100 \%$ & $\begin{array}{l}\text { Cong. } \\
\text { form: } \\
100 \%\end{array}$ \\
\hline $\begin{array}{l}\text { Cornelia de } \\
\text { Lange s." } \\
(122470)\end{array}$ & $\begin{array}{l}\text { Growth retardation } \\
\text { Upper limb anomalies } \\
\text { Typical face }\end{array}$ & $5 p 13.1$ & NIPBL & $50 \%$ & Almost $100 \%$ \\
\hline $\begin{array}{l}\text { Tuberous } \\
\text { sclerosis } \\
\text { complex } \\
\text { (191100') }\end{array}$ & $\begin{array}{l}\text { Hamarromata } \\
\text { Epilepsy }\end{array}$ & $\begin{array}{l}9 q_{34} \\
16 \mathrm{p} 13\end{array}$ & $\begin{array}{l}T S C 1 \\
T S C 2\end{array}$ & $80 \%$ & $>50 \%$ \\
\hline $\begin{array}{l}\text { Sotoss } \\
(117550)\end{array}$ & $\begin{array}{l}\text { High bithweight } \\
\text { Overgrowtl } \\
\text { Macrocephaly, } \\
\text { Typical face }\end{array}$ & $5 q 35$ & NSD & $90 \%$ & variable \\
\hline
\end{tabular}

Legend:

- virtually no transmission because of degree of MR and/or reduced fertility

* microdeletions, patternal UPD 15 and mutations

** microdeletions and maternal UPD 15

*** including microdeletions; most of mutations found in CREB 


\section{REFERENCES}

Abidi FE, Chudley AE, Schwartz CE, Stevenson RE. 2003. XLMR syndromes associated with mutations in the XNP gene. Proc Greenwood Genet Center 22:38-43.

Amir RE, Van den Veyer IB, Wan M, Tran CQ, Francke U, Zoghbi HY. 1999. Rett syndrome is caused by mutations in X-linked MeCP2, encoding methyl-CpG-binding protein 2. Nat Genet 23:185-188.

Ausió J, Levin DB, de Amorim GV, Bakker S, Macleod PM. 2003. Syndromes of disordered chromatin remodeling. Clin Genet 64:83-95.

Bienvenu T, Poirier K, Van Esch H, Hamel B, Moraine C, Fryns JP, Ropers HH, Beldjord C, Yntema HG, Chelly J. 2003. Rare polymorphic variants of the AGTR 2 gene in boys with non-specific mental retardation. J Med Genet 40:357-359.

Billuart P, Bienvenu T, Ronce $N$, des Portes $V$, Vinet MC, Zemni R, Roest Crollinus $H$, Carrie A, Fauchereau F, Cherry M, Briault S, Hamel B, Fryns JP, Beldjord C, Kahn A, Moraine $\mathrm{C}$, Chelly J. 1998. Oligophrenin-1 encodes a rhoGAP protein involved in $X$ linked mental retardation. Nature 392:923-926.

Chelly J, Mandel J-L. 2001. Monogenic causes of X-linked mental retardation. Nat Rev Genet 2:669-680.

Costa Lima MA, Pinentel MM. 2004. Dynamic mutation and human disorders: the spinocerebellar ataxias (review). Int J Mol Med 13:299-302.

Curry CJ, Stevenson RE, Aughton D, Byme J, Carey JC, Cassidy S, CunniffC, Graham JM Jr, Jones MC, Kaback MM, Moeschller J, Schaefer GB, Schwartz S, Tarleton J, Opitz]. 1997. Evaluation of mental retardation: recommendations of a consensus conference. Am J Med. Genet 72:468-477.

De Vries BB, van den Ouweland AM, Mohkarnsing S, Durvenvoorden H], Mol E, Gelsema K, van Rijn M, Halley DJ, Sandkuijl LA, Oostra BA, Tibben A, Niermeijer MF. 1997. Screening and diagnosis for the fragile $X$ syndrome among the mentally retarded: an epidemiological and psychological sinrvey. Collaborative Fragile X Study Group. Am J Hum Genet 61:660-667.

De Vries BBA, Halley DJ], Oostra BA, Niemeijer MF. 1998. The fragile X syndrome. J Med Genet 35:579-589.

De Vries BBA, Mohkamsing $S$, wan den Ouweland AMW, Mol E, Gelsema $K$, van Rijn $M$, Tibben A, Halley DJ, Duivenvoorden HJ, Oostra BA, Niermejer MF. 1999. Screening for the fragile $X$ syndrone among the mentally retarded: a clinical study. The Collaborative Fragile X Study Group. J Med Genet 36:467-70.

Frints SGM, Froyen G, Marynen P, Fryns J-P. 2002. X-linked mental retardation: vanishing boundaries between non-specific (MRX) and syndromic (MRXS) forms. Clin Genet 62:423-432.

Giangreco CA, Steele MW, Aston CE, Cummins JH, Wenger SL. 1996. A simplified six-item checklist for screening for fragile $\mathrm{X}$ syndrome in the pediatric population. $J$ Pediatr 129:611-614. 
Gibbons RI, Picketts DJ, Villard L, Higgs DR. 1995. Mutations in a putative global transcriptional regulator cause $X$-linked mental reatrdation with a-thalassemia (ATR-X syndrome). Cell $80: 837-845$.

Gilgenkrantz S, Mujica P, Gruet P, Triclon $P$, Schweitzer F, Nivelon-Chevallier A, Nivelon $J_{\text {. }}$ Coulllault $G$, David $A_{w}$ Verloes $A_{\text {, }}$ Lambotte C, Piussan C, Mathieu M. 1988. CoffinLowry syndrome: a mullticenter study. Clin Genet 34:230-245.

Hagberg $B$, Goutieres $F$, Hanefeld F, Rett A, Wilson J. 1985. Rett syndrome: criteria for inclusion and exclusion. Brain Dev 7:372-373.

Hagberg B, Hanefeld F, Percy A, Skjeldal O. 2002. An update on clinically applicable diagnostic criteria in Rett syndrome. Eurp J Paed Neurol 6:293-297.

Hagerman PJ, Hageman RJ 2004a. Fragile X-associated tremor/ataxia syndrome (FXTAS). Ment Retard Dev Disabil Res Rev 10:25-30.

Hagerman PJ, Hageman RJ. 2004b. The fragile-X premutation: a maturing perspective. Am J Hum Genet 74:805-816. Erratum in: Am J Hum Genet; 75:352.

Hamel BC, Poppelaars FA. 2000. Geslachtsgebonden mentale retardatie. Ned Tijdschr Geneeskd 144:1713-1716.

Hamel $\mathrm{BCI}$. 1999. X-linked mental retardation. A clinical and molecular study [thesis]. Nijmegen: Katholieke Universiteir. ISBN 90-76727-01-5.

Hanauer A, Young ID. 2002. Coffn-Lowry syndrome: clinical and molecular features. J Med Genet 39:705-713.

Higgins J], Pucilowska J, Lombardi RQ, RooneyJP. 2004. Canidate genes for recessive nonsyndromic mental retardation on chromosome 3p (MRT2A). Clin Genet 65:496-500.

Howard MT, Malik N, Anderson CB, Voskuil JL, Ackins.JF, Gibbons RJ. 2004. Attenuation of an amino-terminal premuature stop codon mutation in the ATR $X$ gene by an alternative mode of translational initiation. J Med Genet 41:951-956.

Hunter, AGW. 2002. Coffin-Lowry syndrome: a 20-year follow-up and review of long-term outcomes. Am J Med Genet 111:345-355.

Jenser LR, Amende M, Gurok U, Mose: B, Gimmel V, Tzschach A, Janecke AR, Tariverdian $G_{0}$ Chelly J, Fryns JP, Van Esch H, Kleefstra T, Hamell B, Morame C, Gece J, Tumer G, Reinhardr R, Kalscheuer VM, Ropers HH, Lenzner S. 2005. Mutations in the JARIDIC gene, which is involved in transcriptional regulation and chromation remodeling, cause X-linked mental retardation. Am J Hum Genet 76:227-236.

Kalschener VM, Freude K, Musante L, Jemsen LR, Yntema HG, Gecz J, Sefiani A, Hoffmann K, Moser B, Hass S, Gurok U, Haesler S, Aranda B, Nshedjan A, Tzschach A, Hartmann N, Roloff TC, Shoichet S, Hagens O, Tao J, Van Bokhoven $H$, Turner $G$, Chelly J, Moraine C, Fryns JP. Nuber U, Hoeltzenbein M, Scharff C, Scherthan H, Lenzner S, Hamel BC, Schweiger S, Ropers HH. 2003. Mutations in the polyglutamine binding protein 1 gene cause X-linked mental retardation. Nat Genet 35:313-315.

Kerr AM. 1992. Rett Syndrone British longitudinal study (1982-1990) and 1990 survey; in Roosendaal JJ (ed): Mental retardation and Medical Care. Zeist, pp143-145.

Kitamura K, Yanazawa M, Sugiyama N, Miura H, lizuka-Kogo A, Kusaka M, Omichi K, Suzuki R, Kato-Fukui Y, Kamiirisa K, Matsuo M, Kamijo S, Kasahara M, Yoshioka H, 
Ogata T, Fukuda T, Kondo I, Kato M, Dobyns WB. Yokoyana M, Morolashi K, 2002. Mutation of ARX causes abnormal development of forebrain and testes in mice and $X$ linked lissencephaly with abnomal genitalia in humans. Nat Genetics 32:359-369.

Lehrke RG. 1974. X-linked mental retardation and verbal disability. A report to the Minnesota association for retarded children published for the national foundation-March of Dimes (1968). New York and London: International Medical Book Corporation.

Lenski C, Abidi F, Meindl A, Gibson A, Platzer M, Frank Kooy R. Lubs HA, Stevenson RE; Ramser J, Schwartz CE. 2004. Novel truncating mutations in the polyglutamine tract binding protein 1. gene ( $\mathrm{PQBP} 1$ ) cause Renpenning syndrome and $X$-linked mental retardation in another family with microcephaly. Am J Hum Genet 74:777-780.

Lowry RB, Miller JR, Fraser FC. 1971. A new dominant gene mental retardation syndrome: associated with small stature, tapering fingers, characteristic facies, and possible hydrocephalus. Am J Dis Child 121:496-500.

Lubs H. 1969. A marker X chromosome. Am J Hum Gener 21:231-244.

Mandel J-L, Chelly J. 2004. Monogenic X-linked mental retardation: is it as frequent as currently estimated? The paradox of the ARX (Aristaless X) mutations. Eur J Hum Genet $12: 689-693$.

Martin JP, Bell J. 1943. A pedigree of mental defect showing sex-linkage. J Neurol Psych 6:154-157.

Miltenberger-Miltenyi G, Laccone F. 2003. Mutations and polymorphisms in the human methyl CpG-binding protein MECP2. Hum Mut 22:107-115

Molinati F, Rio M, Meskenaite $V$, Encha-Razavi F, Auge J, Bacq D, Briault S, Vekemans M, Munnich A, Attie-Bitach T, Sonderegger P, Colleaux L. 2002. Truncating neurotrypsin mutation in autosomal recessive nonsyndromic mental retardation. Science 298:17791781 .

Oberle I, Rousseau F, Heitz D, Kretz C, Devys D, Hanauer A, Boue J, Bertheas MF, Mandel JL. 1991. Instability of a 50-base pair. DNA segment and abnormal methylation in fragile $X$ syndrome. Science 252:1097-1102.

Oostra BA, Chiurazzi P. 2001. The fragile X gene and its function. Clin Genet 60:399-408.

Orrico A, Galli L, Cavaliere ML, Garavelli L, Fryns JP, Crushell E, Rinaldi MM, Medeira A, Sorrentino V. 2004. Phenotypic and molecular characterisation of the Aarskog-Scott syndrome: a survey of the clinical variability in light of FGD1 mutation analysis in 46 patients. Eur J Hum Genet 12:16-23.

Partington MW, Turner G, Boyle J, Gécz J. 2004. Three new fandilies with X-linked mental retardation caused by the $428-451$ dup (24bp) mutation in ARX. Clin Genet 66:39-45.

Penrose LS. 1938. A climical and genetic study of 1280 cases of mental defect. Special report series. London: Medical Research Council.

Philip N, Chabrol B, Lossi AM, Cardoso C, Guerrini R, Dobyns WB, Raybaud C, Villard L. 2003. Mutations in the oligophrenin-1 gene (OPHN1) cause $X$ linked congenital cerebellar hypoplasia. J Med Genet 40:441-446.

Ramakers GJ. 2000. Rho proteins and the cellular mechanisms of mental retardacion. Am J Med Genet 94:367-371. 
Ramakers Gif. 2002. Rho proteins, mental retardation and the cellular basis of cognition. Trends Neurosci 25: 191-199.

Ropers HH, Hamel BC. 2005. X-linked mental retardation. Nat Rev Genet 6:46-57.

Salomons GS, wan Dooren SM, Verhoeven NM, Marsden D, Schwartz C, Cecil KM, DeGraw TJ, Jakobs C. 2003. X-linked creatine transporter defect an overview. J Inherit Metab Dis 26:309-318.

Sheman SL. 2000. Premature ovarian falure in the fragile $X$ syndrome. Am J Med Genet 97: 189-194.

Smeets Ex Schollen E, Moog U, Matthijs G, Herbergs J. Smeets $H$, Curfs L, SchranderStumpel C, Fryns JP. 2003. Rett syndrome in adolescent and adult females: clinical and molecular genetic findings. Am J Med Genet 122A:227-233.

Smeets EEJ. 2005. Ratt syndrome 1954-2004 [Thesis]. Maastricht: Universitaire Pers Maastricht. ISBN 9052784639.

Stevenson R, Schwartz C, Schroer. 2000. X-linked mental retardation. New York, Oxford: Oxford University Press.

Stevenson RE, Schwartz CE. 2002. Clinical and molecular contributions to the understanding of X-linked mental retardation. Cytogenet Genome Res 99:1-4.

Stevensan RE, Schwartz CE. 2004. Syndromic and nonsyndromic X-linked mental retardation: molecular advances are beginning to blur the distinction. Proc Greenwood Genet Center $23: 113$.

Stevenson RE, Bennett CW, Abidi F, Klefstra T, Porteous M, Simensen RI, Lubs HA, Hamel BCl, Schwartz CE. 2005. Renpenning syndrome comes into focus. Am J Med Genet 134A:415-421.

Stromme P, Mangelsdorf ME, Shaw MA, Lower KM, Lewis SME, Bruyere H, Lutcherath V, Gedeon AK, Wallace RH, Scheffer IE, Turner G, Partington M, Frints SGM, Fryns J-P, Sutherland GR, Mulley JC, Gecz J. 2002. Mutations in the human ortholog of aristaless cause X-linked mental retardation and epilepsy. Nature Genet 30:441-445.

Sutherland GR. 1977. Fragile sites on human chromosomes: demonstration of their dependence on the type of tissue culture medium. Science 197:265-266.

The Rett Syndrome Diagnostic Criteria Work Group. 1988. Diagnostic criteria for Rett syndrome. Ann Neurol 23:425-428.

TrivierE, De Cesare D Jacquot S, Pannetier S, Zackai E, Young I, Mandel J-L, Sassone-Corsi P. Hanatuer A. 1996. Mutations in the kinase Rsk-2 associated with Coffin-Lowry syndrome. Nature 384:567-570.

Verkerk AJ, Pieretti M, Sutcliffe IS, Fu YH, KuhJ DP", Pizzuti A, Reiner O, Richards S,

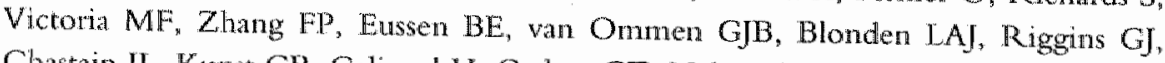
Chastain JL, Kunst CB, Galjaard H, Caskey CT, Nelson DL, Oostra BA, Warren ST. 1991. Identification of a gene (FMR-1) containing a CGG repeat coinicident with a breakpoint cluster region exhibiting length variation in fragile $X$ syndrome. Cell 65:905914. 
Vervoort VS, Beachem MA, Edwards PS, Ladd S, Miller KE, de Mollerat X, Clarkson K, DuPont B, Schwartz CE. Stevenson RE, Boyd E, Srivastawa AK. 2002. AGTR2 mutations in X-linked mental retardation. Science 296: 2401-2403.

Watren ST. Nelson DL. 1994. Advances in molecular analysis of fragile X syndrome. JAMA $271: 536-542$.

Yntema HG, Poppelaars FA, Derksen E, Oudakker AR, Roosmalen $T$ van, Jacobs A, Obbema H, Brunner HG, Hamel BCJ 2002. Expanding phenotype of XNP mutations: mild to moderate mental retardation. Am J Med Genet 110:243-247.

Yu S, Pritchard M, Kremer E, Lynch M, Nancarrow J, Baker E, Holman K, Mulley JC, Warren ST, Schlessinger D, Sutherland GR, Richards RI. 1991. Fragile X genotype characterized by an unstable region of DNA. Science 252:1179-1181.

Zeniou M, Pannetier S, Fryns JP, Hanauer A. 2002. Unusual splice-site mutations in the RSK2 gene and snggestion of genetic heterogeneity in Coffin-Lowry syndrome. Am J Hum Genet 70:1421-1433. 
116 CHATER 


\subsubsection{Neurodevelopmental disorders in males related to the gene causing Rett syndrome in females (MECP2)}

Ute Moog $1,2^{\star}$, Eric EJ Smeets ${ }^{*}$, Kees EP van Roozendaal ${ }^{1}$, Sam Schoenmakers', Jos Herbergs ${ }^{1,2}$, Anneke MJ Schoonbrood-Lenssen ${ }^{3}$, Connie TRM Schrander-Stumpel ${ }^{1.2}$

'Department of Clinical Genetics, University Hospital Maastricht, Maastricht, The Netherlands ${ }^{2}$ Research Institute Growth \& Development (GROW), Maastricht University, Maastricht, The Netherlands; "Center for People with Intellectual Disability "Pepijn', Echt, The Netherlands.

"equal contribution by both authors

Eur J Paed Neurol 2003;07:5-12 (Review) 


\begin{abstract}
Mutations in the $M E C P 2$ (methyl-CpG-binding protein 2) gene are known to cause Rett syndrome, a well known and clinically defined neurodevelopmental disorder. Rett syndrome occurs almost exclusively in females and for a long. time was thought to be an $X$-linked dominant condition lethal in hemizygous males. Since the discovery of the MECP2 gene as the cause of Rett syndrome in 1999, MECP2 mutations have, however, also been reported in males. These males phenotypically have classical Rett syndrome when the mutation arises as somatic mosaicism or when they have an extra $X$ chromosome. In all other cases, males with MECP2 mutations show diverse phenotypes different from classical Rett syndrome. The spectrum ranges from severe congenital encephalopathy, mental retardation with various neurological symptoms, occasionally in association with psychiatric illness, to mild mental retardation only. We present a 21-year-old male with severe mental retardation, spastic tetraplegia, dystonia, apraxia and neurogenic scoliosis. A history of early hypotonia evolving into severe spasticity, slowing of head growth, breathing irregularities and good visual interactive behaviour were highly suggestive of Rett syndrome. He has al de nowo missense mutation in exon 3 of the MECP2 gene (P225L). The clinical spectrum and molecular findings in males with MECP2 mutations are reviewed.
\end{abstract}

Keywords: male; MECP2; missense mutation; Rett syndrome 


\section{INTRODUCTION}

Rett syndrome (RTT, MIM $\star 312750$ ) is a progressive neurodevelopmental disorder occurring almost exclusively in females. After an apparently normal development until 6-18 months of age, girls with classical RTT show regression with deceleration of head growth and loss of speech and acquired motor skills, in particular purposeful hand use. They develop stereotypic hand movements, breathing irregularities, ataxia and seizures. After a period of pseudo-stabilisation and then further deterioration, the condition is mostly characterised by severe mental retardation with a relatively spared and often remarkable visual communicative ability, a progressive scoliosis and a variable degree of spasticity and rigidity often leading to wheelchair dependency. Clinical diagnosis is made in accordance with recognized criteria. ${ }^{1}$ A part from classical RTT, a forme fruste, a variant with preserved speech, cases with late onset of regression and congenital onset variants are known to occur in females.

In 1999 , RTT was reported to be caused by mutations in the gene encoding methyl-CpG-binding protein 2 (MECP2) located at chromosome $\mathrm{Xq} 28 .{ }^{2} \mathrm{RTT}$ had been thought to be an $\mathrm{X}$-linked dominant condition leading to prenatal death in hemizygous males. In recent years however, $M E C P 2$ mutations have also been reported in males. These males may present with a RTT phenotype when they have X-chromosome aneuploidy or somatic mosaicism for the mutation. However, when MECP2 mutations occur in non-mosaic form and in chromosomally normal males, they lead to various neurological phenotypes different from RTT. We present a 21 year old male with severe mental retardation and a neurological disorder with features reminiscent of RTT in whom a de novo $M E C P 2$ mutation was found, and review reported male patients with a MECP2 mutation.

\section{CASE REPORT}

\section{Patient report}

The patient was born at term with a birthweight of $3900 \mathrm{~g}$. Pregnancy and delivery had been uneventful. He had two older healthy brothers. The family history was negative for mental retardation and neurological disorders. There were no feeding problems. His very early infantile development was reportedly normal. Head circumference at birth is unknown but was $46.5 \mathrm{~cm}$ at age 11 months and $47.5 \mathrm{~cm} 3$ months later (both slightly below the 50 th centile). Around 3.5 months of age, his mother noticed 'a change' in making contact and in behaviour towards her. Shortly thereafter, he began to show axial hypotonia and a 
marked head lag. His psychomotor development became severely retarded. He never learned to sit alone nor to walk and lost his ability to stand with support at the age of 2 years. However, he had some fine motor adaptive ability. From 2 years onwards, he showed motor restlessness and developed extrapyramidal symptoms. There was no speech development. He apparently had epilepsy from infancy to 7 years of age. A video taken at 11 years of age shows his posture in the wheelchair to be hypotonic with severe kyphoscoliosis and pelvic asymmetry. $\mathrm{He}$ could turn the pages of photo albums and booklets. His concentration was poor with little attention span. He developed severe spastic tetraplegia. At the age of 16 years, he lost purposeful handuse and became completely apraxic with flexion contractures of the wrists. There were periods of great anxiety, protest and overagitation associated with dysregulation of body temperature.

On clinical examination at the age of 21 years, he was severely mentally retarded and confined to a wheelchair due to severe spastic tetraplegia. His was lean and small with a head circumference of $53 \mathrm{~cm}$ ( $3^{\text {rd }}$ to $10^{\text {th }}$ centile). He had a severe kyphoscoliosis, a hip dislocation on the right side, joint contractures of fingers, wrists, elbows and knees and had warm, sweaty hands and feet. He was abnormally prone to agitation and to repetitive daytime sleeping. Sometimes he became extremely pale and had shallow breathing interrupted by short apnoeic periods. He was able to eat mashed food, did not chew and had delayed swallowing. He had a good visual contact, recognizing his parents and caregivers both visually and vocally, but seemed to be very reserved towards strangers. His parents described him as having particularly strong feelings of sympathy or antipathy towards other people. He loved music and family soaps on television.

Chromosome analysis showed a normal 46, XY karyotype. A CT scan of the brain at 7 years of age and $M$ MRI scan at 12 years of age, an EEG, SSER, BER and EMG were all reported as normal.

\section{Materials and Methods}

Genomic DNA was prepared from peripheral blood leukocytes using the Wizard Genomic DNA purification kit (Promega) according to manufacturers recommendations.

The MECP2 coding region was polymerase chain reaction (PCR) amplified in eight, mostly overlapping, segments. The obtained PCR products obtained were screened for mutations utilising bi-directional sequencing utilising the Big Dye 2 Terminator Cycle Sequencing Kit (Perkin-Elmer Biosystems). After analysis on the ABI PRISM 3100 Genetic Analyzer (Perkin-Elmer Biosystems) the data were analysed using the Vector NTI DNA allignment software.

The presence of the identified putative mutation site in the MECP2 segment ex 3 b was subsequently assessed using a single-strand conformational polymor- 
phism (SSCP) analysis approach (GenePhor, Pharmacia Biotech) under the conditions showing an altered migration profile when the nucleotide substitution is present. As well as the DNA of the patient, his mother and brothers, an additionall 96 control chromosomes ( 25 female and 46 male) were included in the SSCP study.

\section{Results}

DNA sequence analysis of the $M E C P 2$ gene of our index patient revealed the presence of a cytosine to thymidine nucleotide substitution at position 674 of the coding region. This nucleotide substitution $(\mathrm{C} 674 \mathrm{~T})$ leads to a proline to leucine amino acid change in the transcriptional repression domain (TRD) at position 225 of the MeCP2 protein (P225L). In contrast, subsequent DNA sequence analysis of the patient's mother and two elder brothers showed no base alteration in the MECP2 gene. These results were confirmed by SSCP analysis. In comparison to the gel mobility profile of his family members, only the patient's amplified MECP2 segment ex $3 \mathrm{~b}$ DNA showed an altered profile, indicative of the presence of a base change. Similarly, no changed mobility profiles were observed with the SSCP analysis of the 96 control chromosomes.

Consequently, our data indicate that the observed C674T substitution in our patient has arisen de novo and is not to be found in the general population.

\section{CLINICAL CHARACTERISTICS OF MECP2-RELATED DISORDERS IN MALES}

Since 1999 , there has been a growing number of publications reporting male patients with a MECP2 mutation. A summary of these cases, their clinical findings, family history and the particular mutation is given in Table 1.3-30 The phenotypes cover a huge spectrum of neurodevelopmental disorders, ranging from classical RTT to mild mental retardation only and encompass congenital encephalopathy and mental retardation of different degrees in association with diverse neurological features and/or psychiatric illness.

Male patients who presented with a classical or almost classical RTT phenotype can be divided into two groups: those with aneuploidy of the $\mathrm{X}$-chromosome (patients 1-4 in Table 1) and those in whom somatic mosaicism of the MECP2 mutation was found (patients 5-7). In the former group, one mutation is reported as a de novo mutation, ${ }^{5}$ in the other reports this is not specified. The mutations in the latter group arose by definition due to a postzygotic event and thus occurred de novo. The RT T phenotype of both groups can be explained by the presence of a second X-chromosome containing the normal wild type allele as is the case in 
female RTT. In both groups, patients are not consistently hemizygous for the mutation and thus differ considerably from cases $8-25$ whom may be regarded as having true mantestations of $M E C P 2$-related disorders in males.

Five patients (cases numbers $8-12$ in Table 1) presented with a severe congenital encephalopathy and died during the first wo years of life " $15-19$ They were all born in families with girls affected with typical R TT and/or a second boy with the same condition. Two of the five mothers were identified as asymptomatic mutation carriers with a skewed $X$-inactivation pattern, ${ }^{4-16}$ and another manifested mild learning disability and mild neurological symptoms. ${ }^{15}$ In the other two mothers, no mutation was found in blood; the recurrence of the mutation in a second child was most probably due to gemline mosaicism. ${ }^{18-19}$

Cases 13-18 all concemed families with several affected males. ${ }^{20-28}$ Most of them presented with a combination of neurological symptoms and mental retardation. The neurological features were very diverse and comprised pyramidal and extrapyramidal symptoms, ataxia, seizures and hypotonia. The degree of mental retardation was severe (Case 13 and 14) to mild (Case 15 and 18) and showed intrafamilial variability (Case 16). In case 18, no neurological symptoms were associated with mental retardation. The males described by Klauck et al. (Case 17) showed a combination of mental retardation, neurological symptoms (pyramidal signs), psychosis and macro-orchidism, the so called PPM-X syndrome ${ }^{27}$ In this Gamily, the clinical features were variable as there were males with or without a psychatric illness. One of the affected males of Case/Family 15 had severe behavioural problems. Regarding the carrier women, most were asymptomatic (Families 16-18, some carriers of Families 13 and 15) whereas others showed mild symptoms (borderline intelligence or mild retardation, mild hypotonia, gait disturbance, speech difficulty, tremor).

In Cases 19-22, only one male was affected due to a familial MECP2 mutation detected also in at least the mother; these female mutation carriers were asymptomatic. In Cases 23 and 24, no DNA of the mother was avalable for mutation analysis. Again, clinical findings comprised mental retardation with (Case 19) or without neurological or other features (Cases 21-24); unfortunately, the clinical documentation of the latter cases was scant. Case 20 presented with a psychiatric and developmental receptive language disorder. ${ }^{30}$ None of the male patients of Cases 13-22 showed deceleration of head growth which is an obligate feature in classical RTT.

When $X$-chromosome inactivation (XCl) was investigated, symptomatic carrier women had a random $X$ chromosome inactivation (Families 13 and 14). In asymptomatic mutation carriers, however, both a skewed (Case 18) and a balanced $X$ chromosome inactivation patcern (Cases $13,19,21,22$ ) were found. Thus the lack of symptoms in carrier women can not consistently be explained by a skewed XCl. 
Compared with the whole group of male patients with a MECP2-related disorder, the present case shows some peculiarities. First, the mutation of our patient arose de novo which was not shown in any of the reported patients. However, the possibility can not be ruled out that the mutation is caused by germline mosaicism in his mother. Second, the clinical course and findings were dominated by features characteristic of RTT: a history of early hypotonia evolving into severe spastic tetraplegia and apraxia, slowing of head growth, neurogenic scoliosis and joint contractures, abnormal breathing pattern and a preserved visual interactive behaviour. The major difference with classical RTT is that postnatally he had only a short period of apparently normal development, that his hand use was relatively preserved for several years and that he did not develop the characteristic, stereotypic hand movements. The present case expands the described spectrum of MeCP2 related phenotypes in male variants of the Rett syndrome occurring in a chromosomally normal boy.

\section{MOLECULAR GENETICS}

\section{$M e C P 2$ protein and gene}

$\mathrm{MeCP} 2$ is an ubiquitously expressed DNA-binding protein, which is particularly abundant in the brain. It contains a methyl-CpG binding domain (MBD), a transcriptional repression domain (TRD), and a final C-terminal segment. MeCP2 binds with its MBD to methylated DNA throughout the genome, is subsequently involved in deacetylation of core histones and chromatin condensation and thus leads to repression of transcription. Loss of function of MeCP2, especially in differentiated, postmitotic neurons, is predicted to lead to deregulated expression of putative target genes with a potential damaging effect during central nervous maturation. ${ }^{31}$

The gene encoding MeCP2 is located at Xq28 and undergoes X-inactivation. It comprises 4 exons, with the coding sequence in exons 2 to $4 .{ }^{32}$ Over 185 mutations have been reported in RTT patients. About two thirds are truncating and one third missense mutations, the latter occurring mostly in the MBD. ${ }^{33-34} 10 \%$ are intragenic deletions or complex rearrangements leading to frameshifts in the $\mathrm{C}$-terminal segment. The mutation detection rate in sporadic female cases with classical RTT is $70-85 \%$ and lower in Rett variants. ${ }^{34}$

\section{MECP2 mutations in male patients}

Most of the mutations found in Cases 1-12 (Table 1) who showed a R T T phenotype or had severe congenital encephalopathy, are known to occur in females 


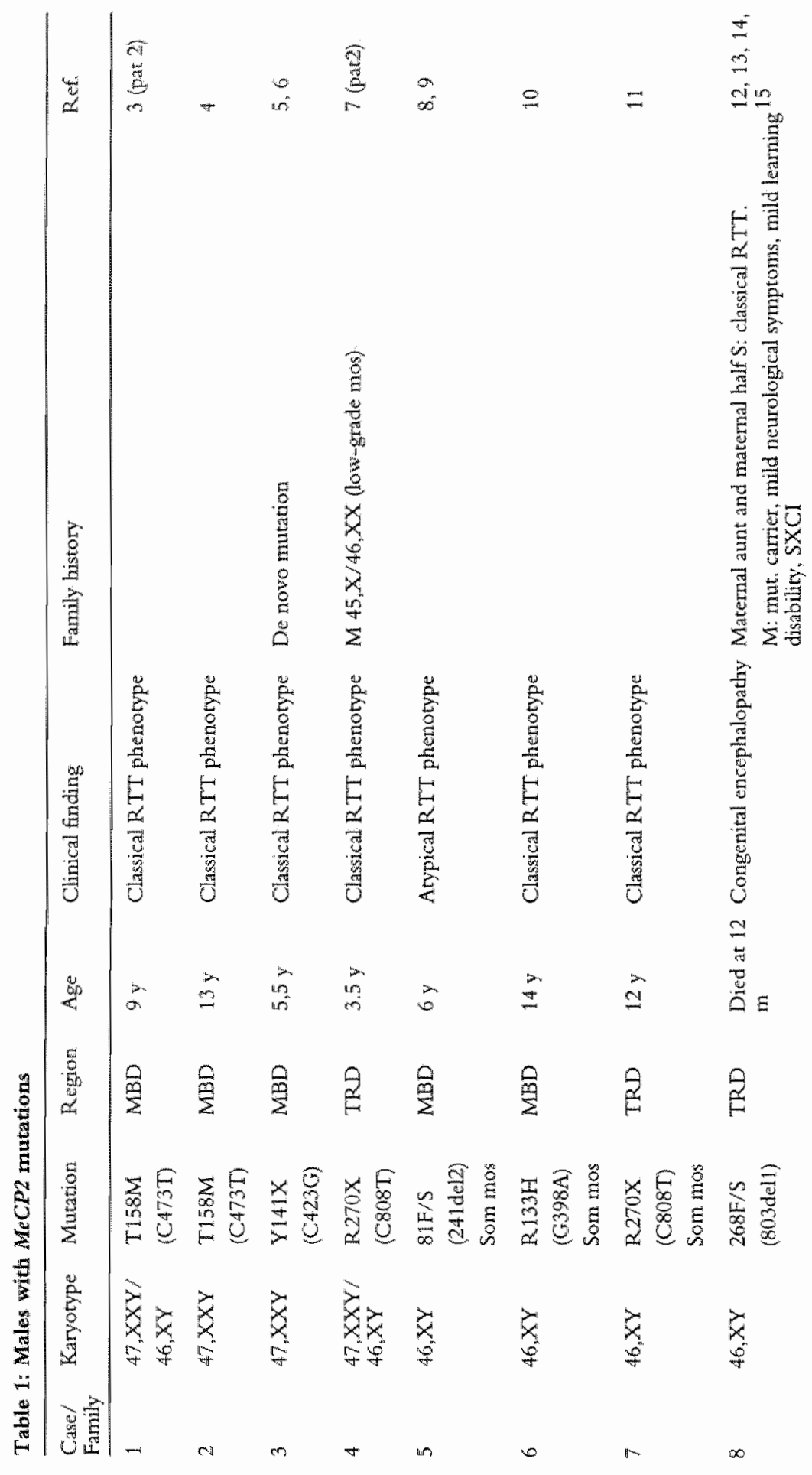




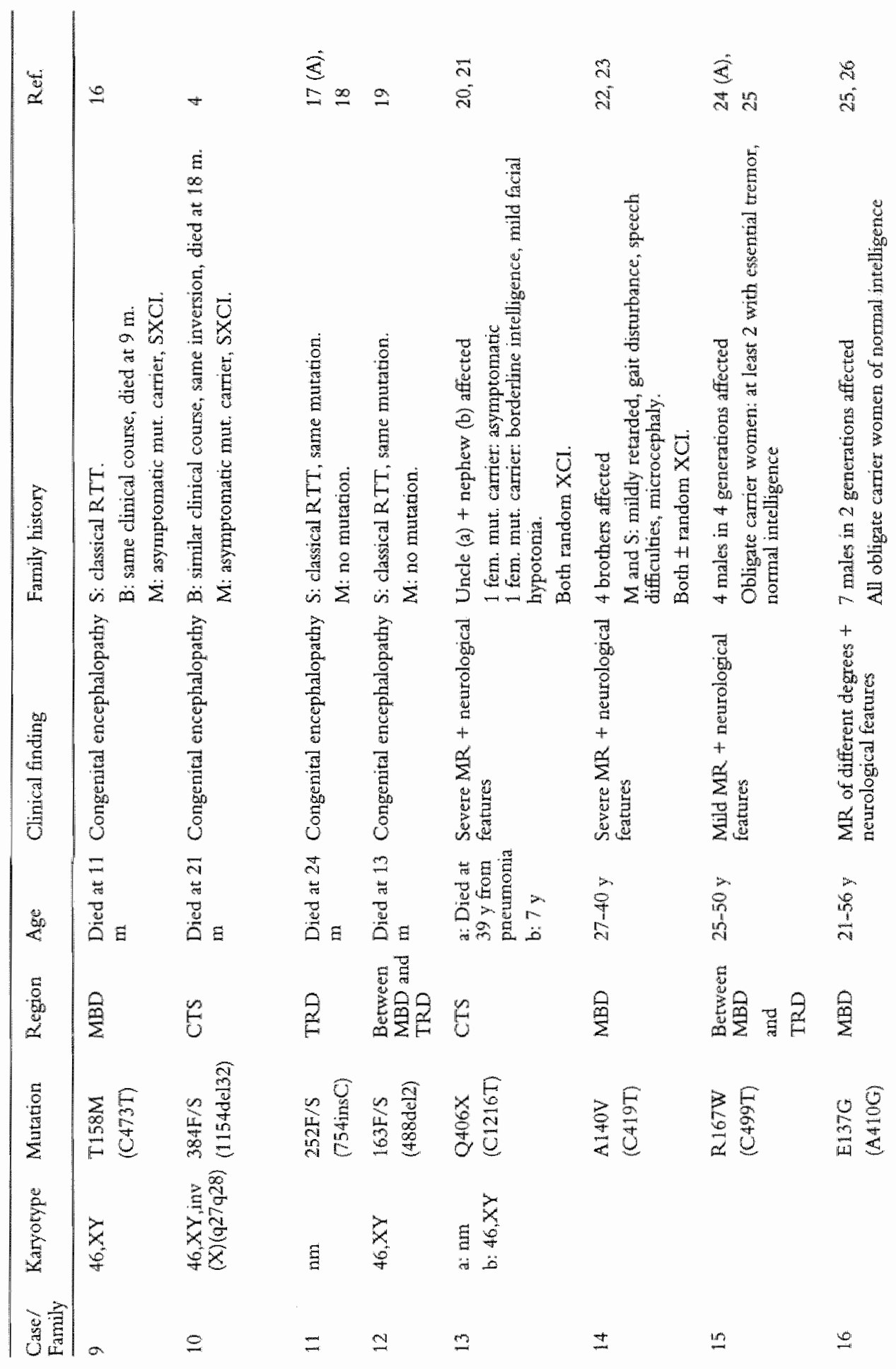




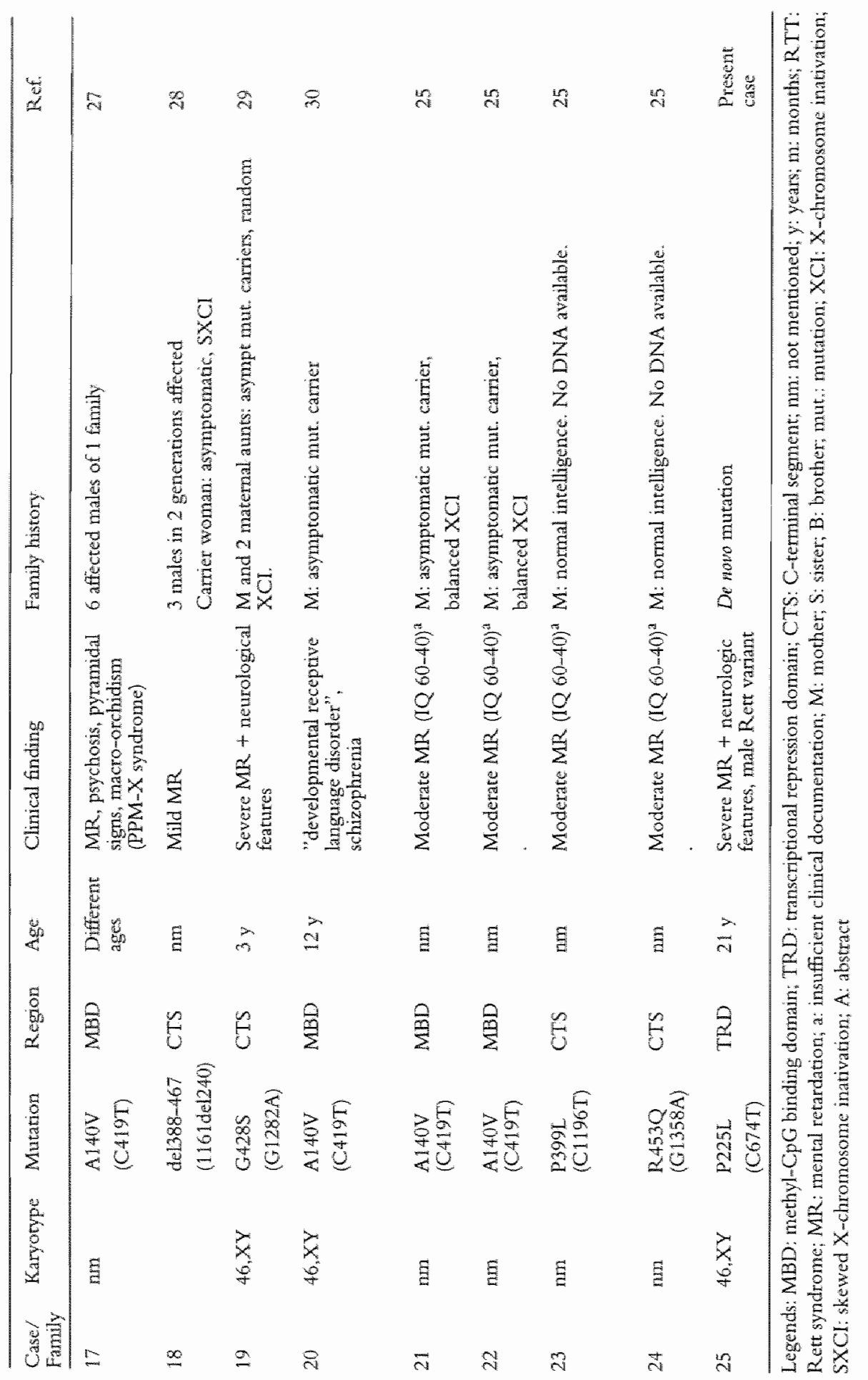


with classical RTT. It is obvious that mutations leading to classical RTT in females do not necessarily result in prenatal death in males; they may be underdiagnosed because of the non-specific congenital onset encephalopathy. ${ }^{35}$ It is also possible that the smaller number of males could relate to the paternal origin of the mutation in a large percentage of girls with classical RTT. However, the relatively milder cases presenting with a spectrum of neurodevelopmental disorders (Cases 13-25) were associated with mutations not found in females with classical RTT. In contrast to the MECP2 mutations reported in girls with classical RTT, truncating mutations (frameshift and stopcodon mutations) seem to be an exception in males with a normal karyotype: apart from one (Case 13) which is a very late truncating mutation, there are no truncating mutations reported in males. The mutation $\mathrm{A} 140 \mathrm{~V}$ is found in several male patients (Cases 14, 17, 20-22) and causes different phenotypes. It is intriguing that in both cases with psychiatric features (Case 17 and 20 ) this mutation was found. Kudo et al. studied the effect of this and the E137G mutation (Case 16) on MeCP2 function as compared with the protein function when a classical Rett mutation is present. ${ }^{36}$ They found evidence for only mild impairment of $\mathrm{MeCP} 2$ function in both cases and argued that $\mathrm{Al} 40 \mathrm{~V}$ is unlikely to be a polymorphism. That different mutations cause different functionality of the MeCP2 protein has certainly to be confirmed by future studies.

The described, newly identified missense mutation (P225L) observed in the boy currently reported is located in the TRD and is a highly conserved residue in mouse, chicken and Xenopus sequences. Since this particular mutation was shown to be de novo, it is highly probable that the leucine substitution is pathogenic. Moreover, a disease causing missense mutation has previously been identified in several female Rett patients at the same position (C674G) in the MECP2 coding sequence, leading to a proline to arginine substitution ${ }^{37-38}$ These two amino acid substitutions in the TRD may well have different effects on the function of the $\mathrm{MeCP} 2$ protein on basis of their chemical constitution and thus manifest distinct phenotypes.

\section{CRITERIA FOR MECP2 SCREENING IN MALES}

On the basis of our current knowledge of MeCP2-related disorders, DNA analysis of the $M E C P 2$ gene in combination with a chromosome investigation should seriously be considered in males with

- classical Rett syndrome,

- congenital encephalopathy, 
- mental retardation and diverse neurological findings (including mental retardation and neurological findings reminiscent of Rett syndrome) when no other explanation has been found after a careful examination,

- a combination of mental retardation, pyramidal signs, psychosis and macroorchidism (PPM-X syndrome).

So far, it is debatable whether non-syndromic X-linked mental retardation (XLMR) should be added to the list of criteria for DNA testing. In the present series, Family 18 is the only example of non-specific mental retardation caused by a MECP2 mutation. Unfortunately, the clinical findings of the four sporadic cases (Cases 21-24) are too poorly documented to exclude further neurological anomalies or features of RTT. ${ }^{25}$ The mutation in family 18 was detected after the screening of 176 families with mental retardation of (possible) X-linked inheritance (material collected by the European XLMR consortium); in 13/176 families, the genetic defect could be linked to $\mathrm{Xq} 28 .{ }^{28} \mathrm{~A}$ subsequent study reported the occurrence of only one MECP2 mutation in 500 males with unexplained mental retardation. ${ }^{39}$ The low yield of these studies weaken the result of a previous study which suggested that MECP2 might be highly mutated in Xlinked mental retardation and account for $\pm 2 \%$ of MR. ${ }^{25}$ No MECP 2 mutations were detected in 42 autistic males with or without mental retardation. ${ }^{40}$ In conclusion, MECP2 mutations give rise to a spectrum of neurodevelopmental disorders in males which partially depend on the type of mutation and functionality of the protein. ${ }^{36}$ Further studies will broaden our view on the clinical spectrum and possibly modify the criteria for testing.

\section{ACKNOWLEDGEMENTS}

We thank DCJ Tserpelis, member of the DNA Diagnostic Laboratory in Maastricht, for his skilful technical assistance.

\section{REFERENCES}

1. The Rett syndrome Diagnostic Working Group. 1988. Diagnostic criteria for Rett syndrome. Ann Neurol 23:425-428.

2. Amir RE, Van den Veyer IB, Wan M, Tran CQ, Francke U, Zoghbi HY. 1999. Rett syndrome is caused by mutations in X-linked MeCP2, encoding methyl-CpG-binding protein 2. Nat Genet 23:185-188.

3. Leonard $H$, Silberstein J, Falk R. Houwink-Manville I, Ellaway C, Raffaele LS, Engerström IW, Schanen C. 2001. Occurrence of Rett syndrome in boys. Child Neurol 16:333-338. 


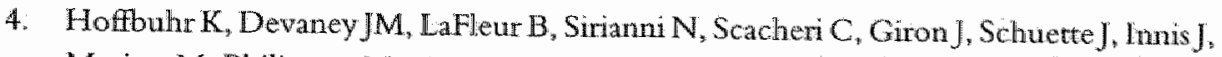
Marino M, Philippart M, Narayanan V, Umansky R, Kronn D, Hoffman EP. Naidu $S$. 2001. MeCP2 mutations in children with and withowt the phenotype of Rett syndrome. Neurology 56:1486-1495.

5. Schwartzman JS, Bemardino A, Nishimura A, Gones RR, Zatz M. 2001. Rett syndrome in a boy with a 47, XXY Karotype. Confimed by a rare mutation in the MeCP2 gene. Neuroped 32:162-164.

6. Schwartzman JS, Zatz M, Vasquez LR, Gomes RR, Koiffimann CP, Fridman C, Otto PG. 1999. Rett syndrome in a boy with a 47, XXX Karyotype. Am J Hum Genet 64:1781-1785.

7. Vorsanova SG, Yurov YB, Ulas VY, Demidova IA, Sharonin VO, Kolotii AD, Gorbatchevskaia NL, Beresheva AK, Soloviev IV. 2001. Cytogenetic and molecularcytogenetic studies of Rett syndrome (RTT): a retrospective analysis of $\mathrm{R}$ ussian cohort of RTT patients (the investigation of 57 girls and three boys). Brain Dev 23(Suppl 1):S196-S201.

8. Clayton-Smith J, Watson P, Ramsden S, Black GCM. 2000. Somatic mutation in MeCP2 as a non-fatal neurodevelopmental disorder in males. Lancet 356:830-832.

9. Watson P, Black G, Ramsden S, Barrow M, Super M, Kerr B, Clayton-Snith J. 2001. Angelman syndrome phenotype associated with mutations in MeCP2, a gene encoding a methyl. CpG binding protein. J Med Genet 38:224-228.

10. Armstrong], Poo P, Pineda M, Aibar E, Gean E, Catala V, Monros E. 2001. Classical Rett syndrome in a boy as a result of somatic mosaicism for a MeCP2 mutation. Ann Neurol $50: 692$.

11. Topcu M, Akyerli C, Sayi A, Toruner GA, Kocoglu SR, Cimbis M, Ozcelik T. 2002. Somatic mosaicism for a MECP2 mutation associated with classic Rett syndrone in a boy. Eur J Hum Genet 10:77-81.

12. Wan M, Zhao K, Lee SS, Francke U. 2001. MECP2 truncating mutations cause histone H4 hyperacetylation in Rett syndrome. Hum Mol Genet 10:1085-1092.

13. Wan M. Lee SS, ZhangX, Houwink-Manville I, Song HR, Amir RE, Budden S, Nardu S, Pereira JLP, Lo IFM, Zoghbi HY, Schanen C, Francke U. 1999. Rett syndrome and beyond: recurrent spontaneous and familial MeCP2 mutations at CpG hotspots. Am J Hum Gener 65:1520-1529.

14. Schanen C, Francke U. 1998. A severely affected male bom into a Ret synd tone kindred supports X-linked inheritance and allows extension of exclusion map. An J Hum Genet $63: 267-269$.

15. Schanen NC, Kurezynski TW, Brunelle D, Woodcock MM, Dure LS, Percy AK. 1998. Neonatal encephalopathy in two male children in families with recurrent Rett syndrome. J Child Neurol 5:229-231.

16. Villard L, Kpebe A, Cardoso C, Chelly J, Tandieu M, Fontes M. 2000. Two affected boys in a Rett syndrome family: Clinical and molecular findings. Neurology 55:11,88-11.93.

17. Orr-Urteger A, Zeev BB, Schanen CN, WolfH, Brandt N, Ginot N, Shomrat R, Yaron Y. 2001. Rett syndrome: clinical manifestations in males with MeCP2 mutations, 
germaline mosaicism and implications for genetic counseling and prenatal diagnosis. Eur] Hum Genet 9(Suppl.1):199.

18. Zeev BB, Yaron Y, Schanen NC, WolfH, BrandtN, GinotN, ShomratR, Orr-Urtreger A. 2002. Rett syndrone: clinical manifestations in males with MECP2 mutations. JChild Neurol $17: 20-24$

19. Geerdink N, Rotteveel JJ, Lammens $M$, Sistermans EA, Heikens GT, Gabreëls FJM, Mullaart RA, Hamel BCJ. 2002. MECP2 mutation in a boy with severe neonatal encephalopathy: clinical, neuropathological and molecular findings. Neuropediatrics 33:33-36.

20. Meloni I, Bruttini M, Longo I, Mari F, Rizzolio P, D'Adamo P, Devriendt K, Fryms JP, Toniolo D, Renieri A. 2000. A mutation in the Rett Syndrome Gene, MeCP2, causes Xlinked mental retardation and progressive spasticity in males. Am J Hum Genet 67.982985.

21. Clacs S, Devriendt K., D'Adamo P, Meireleire J, Raeymaekers P, Toniolo D, Cassiman JJ, Fryns JP. 1997. X-linked severe mental retardation and a progressive neurological disorder in a Belgian family: clinical and genetic studies. Clin Genet 52:155-161.

22. Orrico A, Lam C, Galli L, Dotti MT, Hayek G, Tong SF, Poon MK, Zapella M, Federico A, Sorrentino V. 2000. MeCP2 mutation in male patients with non-specific X-linked mental retardation. FEBS Lett 481:285-288.

23. Dotti MT, Orrico A, De Stefano N, Battisti C, Sicurelli F, Severi S, Lam CW, Galli L, Sorrentino V, Federico A. 2002. A Rett syndrome MECP2 mutation that causes mental revardation in men. Neurology 58:226-230.

24. Verloes A, Cherif B, Briault S, Chelly J 2001. MeCP2 mutation in mild non-specific Xlinked mental retardation family. Eur J Hum Genet 9(Suppl.1):185.

25. Couvert $\mathbb{P}$, Bienvenu $T$, Aquaviva $C$, Poirier $K$, Moraine $C$, Gendrot $C$, Verloes $A$, Andres $\mathrm{C}$, Le Fevre AC, Souville I, Steffann, Des Portes V, Ropers HH, Yntema $\mathrm{HG}_{\text {, }}$ Fryns JP, Briault S, Chelly J, Cherif B. 2001. MeCP2 is highly muted in X-linked mental retardation. Hum Mol Genet 10:941-946.

26. Gendrot $C$. Ronce $\mathbb{N}$, Raynaud M, Ayratut AD, Dourlens J, Castelnau P, Muh JP, Chelly J, Morane C. 1999. X-linked nonspecific mental retardation (MRX16) mapping. to distal $\mathrm{Xq}_{\mathrm{g}} 28$ : linkage study and neuropsychological data in a large family. Am J Med Genet $83: 411-418$.

27. Klauck SM, Lindsay S, Beyer KS, Splitt M, Burn J, Poustka A. 2002. A mutation hot spot for nonspecific $X$-linked mental retardation in the MECP2 gene causes the PPM-X syndrome. Am J Hum Genet 70:1034-1037.

28. Yntema HG, Oudakker AR, Kleetstra $T$, Hamel BCJ, Bokhoven FV, Chelly J, Kalschener VM, Fryns JP, Raynaud M, Moizard MP, Moraine C. 2002. In-frame deletion in MeCP2 causes mild nonspecific mental retardation. Am.J Med Genet 107:81-83.

29. Inessacudene B, Bannefont JP, Royer $G$, Commer-Daire $V$, Lyonnet $S$, Lyon $G$, Munnich A, Amiel J. 2001. MeCP2 mutations in non-fatal, non-progressive encephalopatry in a male. J Med Genet $38 ; 171-174$. 
30. Cohen D, Lazar G, Couvert P, Desportes V, Lippe D, Maet P, Heron D. 2002. MECP2 mutation in a boy with language disorder and schizophrenia. Am J Psychatry 159:148149 (Letter).

31. Ellaway C, Christodoulou J. 2001. Rett syndrome: clinical characteristics and recent genetic advances. Disabil Rehabil 23:98-106.

32. Dragich J, Houwink-Manville I, Schanen C. 2000 . Rett syndrome: a surprising result of mutation in MeCP2. Hum Mol Genet 9:2365-2375.

33. MeCP2 Mutation Database of the Rett Syndrone Research Foundation (http://www.rstf.org/)

34. Lee SSJ, Wan M, Francke U. 2001. Spectrum of MeCP2 mutations in Rett syndrome. Brain Dev 23(Suppl. 1):S138-S143.

35. Schanen C. 2001 . Rethinking the fate of males with mutations in the gene that causes Rett syndrome. Brain Dev 23(Suppl. 1):S144-S146.

36. Kudo S, Nomura Y, Segawa M, Fujita N, Nakao M, Hammer S, Schanen C, Terai I, Tanuma M. 2002. Functional characterisation of MeCP2 mutations found in male patients with $X$ linked mental retardation. \Med Genet (Letter) 39:132-136.

37. Cheadle JP, Gill H, Fleming N, Maynard J, Kerr A, Leonard H, Krawczak M, Cooper DN, Lynch S, Thomas $N$, Hughes $H$, Hulten M, Ravine D, Sampson JR, Clarke A. 2000. Long-read sequence analysis of the MECP2 gene in Rett syndrome patients: correlation of disease severity with mutation type and location. Hum Mol Genet 9:1119-1129.

38. Amir RE, Van den Veyer IB, Schultz R, Malicki DM, Tran CQ, Dahle EJ, Philippi A, Timar L, Percy AK, Motil K], Lichtarge O, Smith EO, Glaze DG, Zoghbi HY. 2000. Influence of mutation type and $X$ chromosome inactivation on Rett syndrome phenotypes. Ann Neurol 47:670-679.

39. Xntema HG, Kleefstra T, Oudakker AR, de Vries BBA, Nillesen W, Sistermans EA, Brunner HG, Hamel BCJ, van Bokhoven H. 2002. Low frequency of MECP2 mutations in mental retardation of unk nown origin: implications for routine DNA diagnostics. Eur] Hum Genet 10(Suppl. 1):229(A).

40. Vourch P, Bienvenu T, Beldjord C, Chelly J, Barthelemy C, Muh JP. Andres C. 2001. No mutations in the coding region of the Rett syndrome gene MeCP2 in 59 autistic patients. Eur J Hum Genet 9:556-558. 
132 CHAPTER 
5.2.2 MECP2 mutations are an infrequent cause of mental retardation associated with neurological problems in male patients

Ute Moog ${ }^{a, b \star}$, Kees van Roozendaal ${ }^{a}$, Eric Smeets ${ }^{a, c}$, Demis Tserpelis ${ }^{3}$, Koen Devriendt ${ }^{c}$, Griet Van Buggenhout ${ }^{c}$, Jean-Pierre Frijns $^{\mathrm{a}, \mathrm{c}}$, and Connie Schrander-Stumpel ${ }^{\mathrm{a}, \mathrm{b}}$

Department of Clinical Genetics, University Hospital Maastricht, Maastricht, The Netherlands;

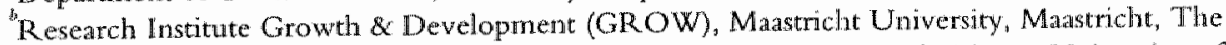
Netherlands; "Center for Human Genetics, Universiry Hospital Gasthuisberg, University of Leuven, Leuven, Belgium. 


\section{ABSTRACT}

Mutations in the methyl-CpG-binding protein 2 (MECP2) gene located on $\mathrm{Xq} 28$, cause Rett syndrome (RTT) in female patients. Meanwhile, non-mosaic MECP2 mutations unknown in girls have been found in an increasing number of male patients with a nomal $46, \mathrm{XY}$ karyotype. They can cause a broad spectrum of neurodevelopmental disorders which often show a combination of mental retardation (MR) with neurological symptoms. We present the results of MECP2 analysis in a group of 72 male patients with an unexplained combination of MR and neurological features, and review the nutational reports published on male patients since the discovery of the MECP2 gene. Analysis included sequencing of exon 1 which thus far was mostly omitted from DNA screening. One pathogenic mutation has been found in a patient with $R$ ett variant, in addition to an unclassified variant and a series of non-pathogenic changes. No changes have been found in exon 1. Criteria for testing of male patients are classic RTT, severe neonatal encephalopathy, and RTT variant which may be clinically underrecognized. Testing can also be considered in males with a combination of unexplained $M R$ and (progressive) neurological manifestations although the yield of $M E C P 2$ analysis is probably low in this situation. Based on the literature, MECP2 testing in males with MR only is debatable.

Keywords: male patients, MECP2, Rett variant, unexplained mental retardation 


\section{INTRODUCTION}

Rett syndrome (RTT, OMIM \#312750) is a clinically defined neurodevelopmental entity occuring mainly in females. Diagnostic criteria have been established for classic RTT leaning upon a characteristic developmental profile, and for variant forms of RTT [1]. RTT is thought to be the 2nd most common cause, after trisomy 21, of severe mental retardation (MR) in females [2]. In up to $90 \%$ of individuals with RTT, mutations in the MECP2 (methyl-CpG-binding protein 2) gene can be found [3-5]. For further review of the clinical and genetic aspects, the reader is referred to a recent publication by Weaving et al. [6]. In the last few years, the phenotypic spectrum of $M E C P 2$ mutations has expanded considerably and mutations have also been reported in an increasing number of male patients, reviewed by others and us $[7,8]$. Apart from males with RTT caused by a MECP2 mutation and $\mathrm{X}$-chromosome aneuploidy or somatic mosaicism of the mutation, and from male patients with severe neonatal encephalopathy due to a known MECP2 mutation, reported cases consist of a group of patients with a broad spectrum of neurodevelopmental disorders. They have MR of various degrees, mostly in combination with neurological features, sometimes associated with psychiatric disorders, up to mild MR only [8]. These individuals often have familial mutations which are unknown to occur in females affected with RTT.

In order to study the phenotypic spectrum, the $M E C P 2$ gene has been screened for mutations in various cohorts of mentally retarded males. The initial suggestion that MECP2 mutations might be a significant cause of MR in males, comparable even to FMR 1 mutations [9], could not be confirmed by further studies as reviewed in detail recently [10]. In the latter study, no pathogenic mutation was found in a group of 103 males with unspecific MR. Interestingly however, the majority of published male patients with $M E C P 2$ mutations presented with $\mathrm{MR}$ in combination with various neurological signs. In addition, MECP2 studies in male patients did often not include analysis of exon 1 . In this study, a group of 72 carefully examined male patients with an unexplained combination of $M R$ and neurological symptoms was tested for MECP2 mutations, including exon 1 analysis. Aim of the study was to further elucidate the phenotype of disorders caused by $M E C P 2$ mutations in males and to reconsider the criteria for mutation analysis. 


\section{PATIENTS AND METHODS}

\section{Patients}

A group of 72 male patients with $M R$ and various neurological symptoms aged 283 years, with a mean age of 29.8 years, was tested for mutations in the MECP2 gene. All patients had undergone a careful clinical evaluation by a pediatrician or a physician for persons with intellectual disabilities, and by a clinical geneticist trained in dysmorphology. Cytogenetic analysis was performed in all and additional investigations (e.g. FMR 1 analysis) in most cases. Patients with known diagnoses, as well as those with dysmorphism, an unexplained MR/multiple congenital anomalies syndrome or with indications for an external (e.g. perinatal) cause of their MR, were not included in the study group. The disorder was reported to be progressive in 12 patients including two with a clinical diagnosis of Rett variant. The neurological features were further unselected, and the patients were affected by one or more of the following features: different forms of epilepsy or seizures, spasticity, hypotonia, dystonia, choreoathetosis, ataxia or other cerebellar signs, tremor, rigidity, and other signs. The most frequent neurological features were epilepsy in 40/72 patients, including 5 males with West or Lennox Gastaut syndrome, and spasticity in $34 / 72$ patients.

\section{Methods}

Total genomic DNA was extracted from blood samples using the Wizard Genomic DNA purification kit (Promega). All 4 exons of $M E C P 2$, including intron-exon boundaries, were amplified by PCR (in overlapping fragments for the exons 3 and 4) in each individual. Purified PCR fragments were screened for mutations by bi-directional sequencing, using the Big Dye Teminator cycle sequencing kit (Applied Biosystems) and analysis on an ABI 3100 DNA automated Sequencer.

The presence of an identified sequence change was tested in a control panel of 100 $X$-chromosomes which derived from 50 healthy male and 25 healthy female individuats.

\section{RESULTS}

In total, 7 sequence changes of the $M E C P 2$ gene were identified (see Table 1). The c.674C $>\mathrm{T}$ mutation ( $\mathrm{p} . \mathrm{P} 225 \mathrm{~L}$ ) occurred in a 22 year old male with $\mathrm{RTT}$ variant. He had an apparently normal early infantile development, showed hypotonia from 4 months of age emerging into severe spasticity, became severely 
retarded and lost his initial motor abilities. At age 22 years, he had severe MR, spastic tetraplegia, dystonia, complete apraxia, neurogenic scoliosis, breathing irregularities and a good visual interactive behaviour highly suggestive for RTT. His data have been published in detail elsewhere [8]. This missense mutation has not been found in DNA of his mother and two brothers, nor in the control panel. The c. $1214 \mathrm{C}>\mathrm{T}$ mutation (p.P405L) was found in a 29 year old male with severe MR. His psychomotor development was retarded from the beginning, he had infantile convulsions and developed epilepsy from age 16 years on, autistic behaviour and characteristic, stereotypic hand movements. His head circumference was normal, he showed neither further neurological signs nor breathing irregularities; his visual interactive behaviour was poor. The family history was complicated by borderline intelligence in both parents and several other paternal and maternal family members. The sequence change was found also in the mother and the patient's sister who was of borderline intelligence and had epilepsy. It has not been detected in the control panel. Male family members were unavailable for testing.

The c. $815 \mathrm{C}>\mathrm{T}$ change (p. $\mathrm{P} 272 \mathrm{~L}$ ) has been registered as polymorphism, unfortunately without reference [11], because it has been found in male and female relatives of a girl with RTT. Very probably, it thus is a nonpathogenic variant. In 4 other males, changes were classified as nonpathogenic variants because they were also found in the healthy maternal grandfather $(c .602 \mathrm{C}>\mathrm{T}$ and c.378-74C $>\mathrm{T}$ ) or in our male control panel $(2 \times$ c.378-17delT), respectively.

\section{DISCUSSION}

In this paper, we report on the results of $M E C P 2$ analysis in 72 male patients with $M R$ and associated neurological features. Adding to a previous review on $M E C P 2$ related disorders in males, we want to update the knowledge on the phenotypic spectrum of MECP2 mutations in males with MR, and we critically review clinical features thought to be suggestive for a $M E C P 2$ mutation in males.

In the reported cohort of 72 male patients with MR and neurological features, 7 sequence changes have been found, of which 5 were probably nonpathogenic variants (see Table 1). The c.674C $>\mathrm{T}$ mutation is thought to be a pathogenic change, as it occurred de novo, is so far unreported in male control panels, and affects a highly conserved residue in the transcriptional repression domain (TRD) [8]. At the same position, $C>G$ transitions have been reported repeatedly as pathogenic mutations. The $c .1214 \mathrm{C}>\mathrm{T}$ mutation is hitherto unreported and affects a conserved residue in the C-terminal segment (CTS). It occurred as a familial mutation, male family members were unavailable for testing and the 


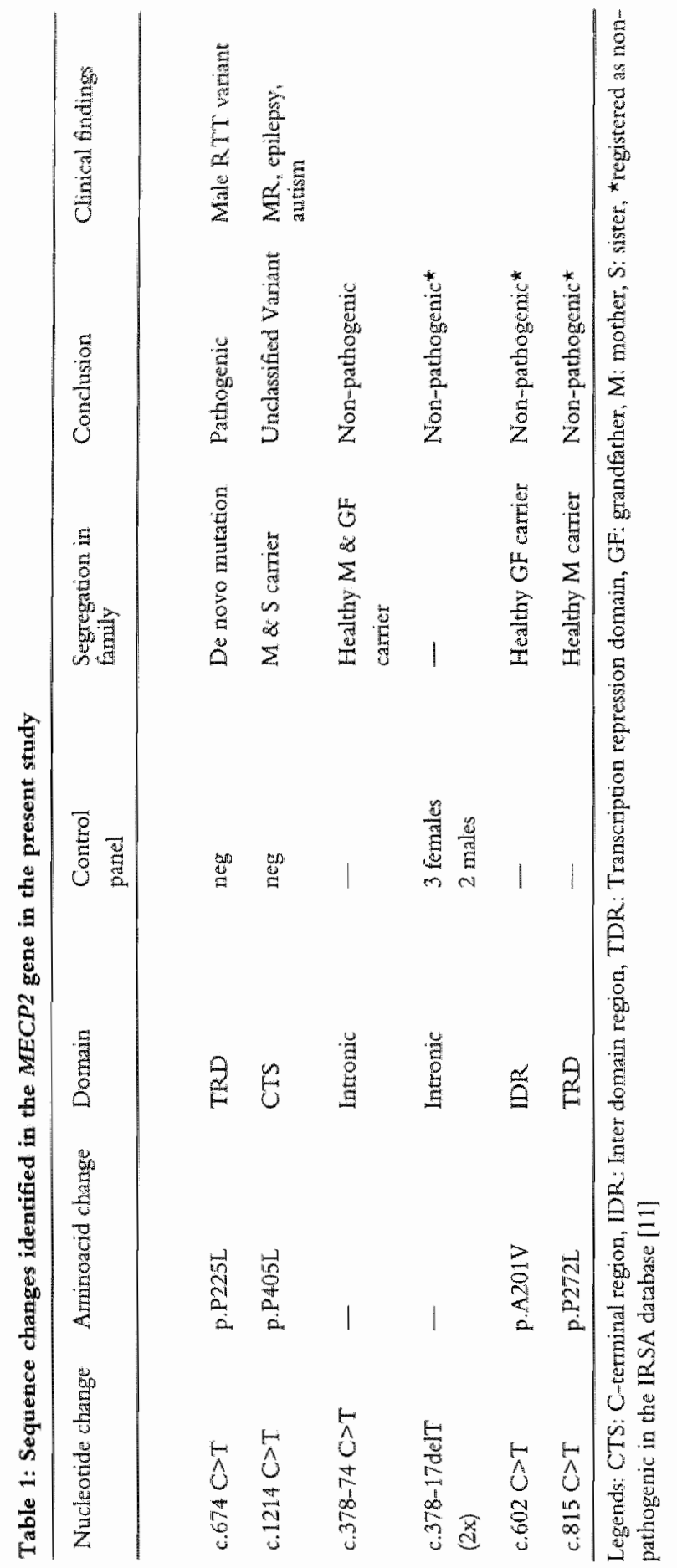


family history made an unmistakable segregation study impossible. Up to now, it has to be regarded as an unclassified variant. The low yield of (possibly) pathogenic changes suggests that a MECP2 mutation does not seem to be a common cause of neurodevelomental disorders even in this clinically highly selected group.

In this study, we also analysed exon 1 and part of the promoter region. Previously, this part of the MECP2 gene was considered noncoding. Recently, however, a new isoform has been discovered encoded by exons 1, 3 and 4, but not exon 2, and named $M E C P 2 B$ [12-14]. MECP2B was shown to be more abundant in human brain than the first described MECP2A isoform. In addition, the translation of the MECP2A transcript is severely impaired by translational interference with the upstream, in exon 1 initiated, open reading frame [12]. Considering these characteristics of $\mathrm{MECP} 2 \mathrm{~B}$, it has been suggested that mutations in exon 1 could possibly be responsible for yet unexplained RTT patients. So far, they have however rarely been found in female patients with classic or atypical R TT testing negative for mutations in exons 2-4 [13-15]. A recent report indicates that exon 1 mutations are not a common cause of X-linked MR in male patients [16]. Previous $M E C P 2$ studies in male patients however did not include exon 1 analysis. The present study does not indicate that the discussed neurodevelopmental disorders in males may be associated with exon 1 mutations. Including exon 1 analysis in routine screens will certainly give more insight in its significance. Because of the possibly crucial function of the MECP2B protein, it can in particular not be excluded that exon 1 mutations may be involved in more severe conditions such as neonatal encephalopathies in males.

Table 2 presents an overview of 8 published cases of neurodevelopmental disorders in males due to presumably pathogenic MECP2 mutations. Three families were identified via the European Consortium for X-linked MR (families MRX16, T36, T44), two of which with nonsyndromic MR (MRX) and one with associated progressive neurological symptoms (MRXS). One further family also showed severe $M R$ and a progressive neurological disorder. Two patients with de novo mutations, including the patient of the present study, had R TT variants. Finally, there were two sporadic patients with mutations in the CTS: one with a de novo mutation and clinical features unreported in all other patients (case 8), and one who clinically poorly documented (case 7). The recessive value of the mutations of these cases is difficult to explain by the type of the mutation and/or the location within the gene, mainly due to the small sample size. Compared to MECP2 mutations causing RTT in females, there are more missense mutations, but nonsense mutations also occur. It is noteworthy that both de novo mutations leading to severe Rett variant, occurred in the TRD and resemble known recurrent mutations in females with R.TT: the p.P225L mutation occurred at the same position as the recurrent p.P225R mutation; and the p.G273fs X mutation 


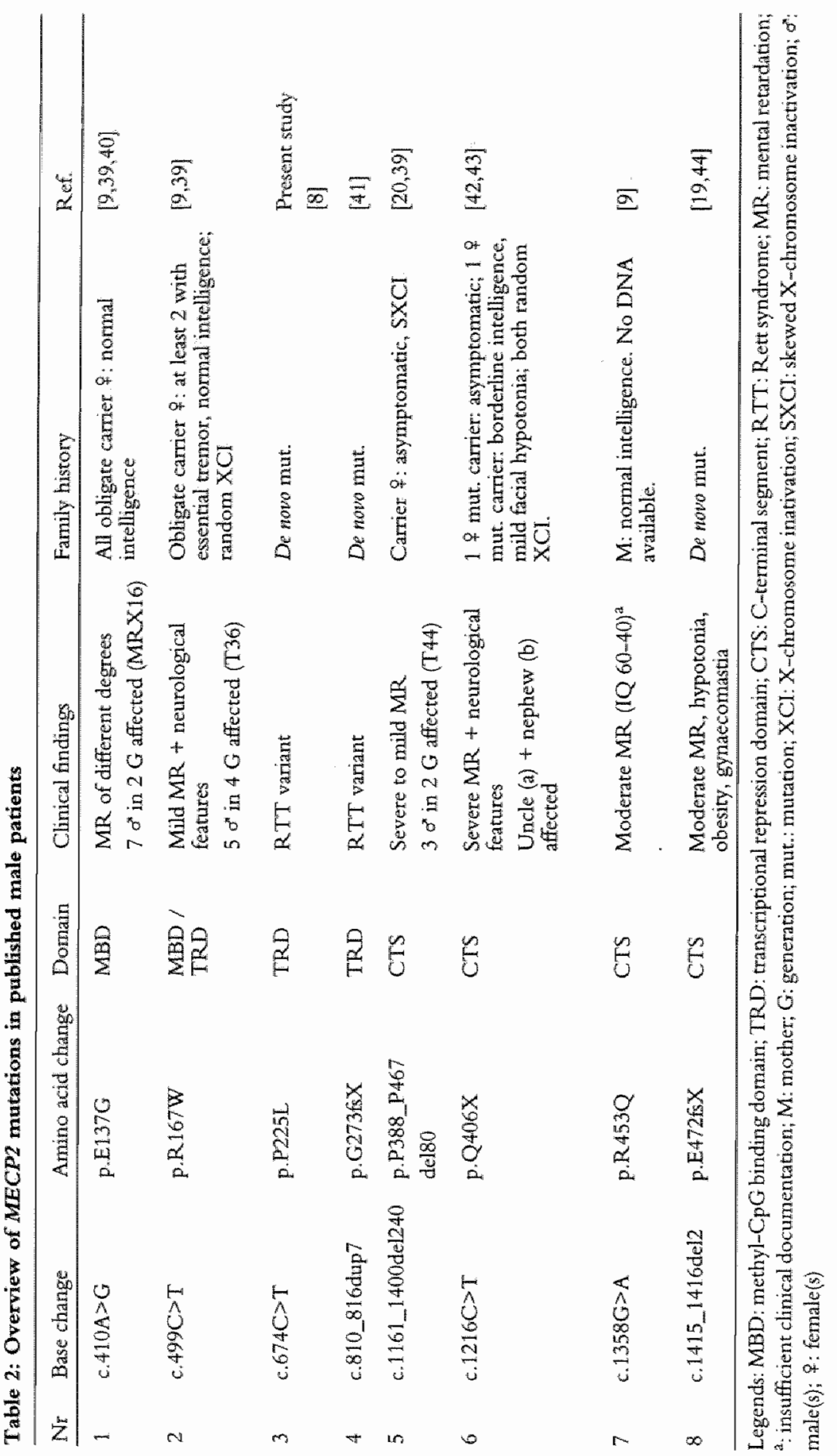


encodes for a protein comparable to the product of mutations c.806delG (p.269fs) and c.808C > T (p.R270X) which occur in 3\% and $6 \%$ of females with RTT, respectively. Mutations that occured in the CTS (cases 5-8) all affect the funcionally essential WW domain binding region which extends from residue 337 to the C terminus [17]. The recent report of a boy with severe retardation and features suggestive of RTT and microduplication $\mathrm{Xq} 28$ involving the MECP2 gene suggests that in some cases, also overexpression of $M E C P 2$ might be pathogenetically involved [18].

Several clinically defined cohorts, including male individuals, have been screened. for $M E C P 2$ mutations. In cohorts of patients with MR only, collected by the XIMR consortium or testing negative for fragile $\mathrm{X}$ syndrome or clinically carefully selected as patients with unspecific MR $[10,19,20]$, a low frequency of mutations has been found. The two patients identified in these studies to have a MECP2 mutation, are included in Table 2 as patients 5 and 8 . Based on our current knowledge, MR alone thus is a debatable criterion for $M E C P 2$ analysis $[10]$.

In view of the clinical overlap between RTT and Angelman syndrome (AS), one further group of interest have been male and female patients with presumed $A S$ who tested negative for $15 q 11-q 13$ abnormalities [21-25]. In these studies, pathogenic MECP2 mutations have been found only in a small percentage of female patients suspected to have AS [21-24]. Remarkably, they partly developed clinically a phenotype consistent with or suggestive of RTT [21-23]. No MECP2 sequence changes of pathogenic value have been found in male patients with a clinical diagnosis of AS so far. Though two patients with somatic mosaicism of a known MECP2 mutation have been ascertained by testing individuals negative for methylation defects in 15q11-q13, they clinically had R T T variant and classic RTT, respectively $[21,24]$. Altogether, MECP2 mutations probably are much less frequently associated with a phenotype consistent with $A S$ than presumed.

As the behaviour of patients with RTT might be mistaken for an autism spectrum disorder, and as RTT is classified as a form of autism in the DSM-IV [26], several studies have also been initiated to screen for MECP2 mutations in a colhort of male and female individuals with autism, with or without MR. Most studies. found no convincing evidence that $M E C P 2$ mutations might contribute to the pathogenesis of autism [27-30], although in one study, pathogenic MECP2 mutations have been found in 2 out of 69 autistic females [31]. However, the behavior of RTT patients most often is distinctly different from autistic behaviors, although low intensity in contact, odd behaviors, attention deficit and hyperactivity may predominate the disorder profile in infants for a long time. RTT is characterized at long term by the dissociation between diminishing neuromotor abilities, and a relatively good visual interactive behavior and preserved personality. 
Combining the results of our study and the literature, $M E C P 2$ analysis should be considered in particular in males with a history suggestive of RTT (RTT variant). As a detailed knowledge of the patient's history and awareness of the behavioral characteristics of R TT, in particular of the visual interactive abilities, is important for the diagnosis of a RTT variant, this disorder is possibly underdiagnosed in male patients. Preliminarily, testing may likewise be considered when MR is associated with a progressive neurological disorder, in particular in the lack of information on the patient's early history, although the yield of testing in this situation seems to be low.

In concurrence with other studies, the detected MECP2 sequence changes comprised a high proportion of nonpathogenic polymorphisms or unclassified variants $[7,10,19]$. The validation of hitherto unreported nucleotide changes leading to amino acid changes, has to be done carefully and shows some general problems. A de novo change is a strong argument for pathogenicity. However, mutations are often fanilial. The change of a highly conserved amino acid or the rareness of a variant which remains undetected in a control panel, are helpful but insufficient arguments to assess pathogenicity. Testing of unaffected male family members is strongly advisable, but often they are inaccessible for investigation. In addition, there are, up to now, very few functional studies $[32,33]$. In general, the pathogenicity of $M E C P 2$ mutations in males can hardly be confirmed and only rejected. We fully agree with Laccone and coworkers who reclassified two previously published cases of presumably pathogenic mutations as non-disease related variants and therefore appealed to "... proceed with caution." [34]. The p.A140V mutation has been reported in 6 other, familial cases with remarkably diverse phenotypes $[9,35-38]$, but so far is of unknown value $[11,34]$.

In conclusion, a synopsis of the current knowledge on MECP2 related disorders in mentally retarded males has been given. For the time being, appropriate criteria for MECP2 testing in male patients are: male $\mathbb{R} T T$, classic or atypical, and severe neonatal encephalopathy negative on testing for other causes. A combination of unexplained MR and (progressive) neurological manifestations, in particular of extrapyramidal and/or pyramidal origin, seems to be a less certain criterion. 


\section{REFERENCES}

1. Hagberg B, Hanefeld F, Percy A, Skjeldal O. An update on clinically applicable diagnostic criteria in Rett syndrome. Comments to Rett Syndrome Clinical Criteria Consensus Panel Satellite to European Paediatric Neurology Society Meting, Baden Baden, Germany, 11 September 2001. Eur J Paediatr Neurol 2002;6:293-297.

2. Hagberg B. Rett syndrome: clinical peculiarities and biological mysteries. Acta Paediatr $1995 ; 84: 9711-976$.

3. Amir RE, Van den Veyer IB, Wan M, Tran CQ, Francke U, Zoghbi HY. Rettsyndrome is caused by mutations in X-linked MeCP2, encoding methyl-CpG-binding protein 2. Nat Genet 1999;23:185-188.

4. Smeets E, Schollen E, Moog U, Matthijs G, Herbergs J, Smeets H, et al. Rett syndrome in. adolescent and adult femalles: clinical and molecular genetic findings. Am J Med Genet $2003 ; 122 \mathrm{~A}: 227-233$.

5. Schanen C, Houwink EJ, Dorrani N, Lane J, Everett R, Feng A, et al. Phenotypic manifestations of MECP2 mutations in classical and atypical Rett syndrome. Am J Med Genet 2004;126A: $129-140$.

6. Weaving LS, Ellaway CI, Gecz J, Christodoulou J. Rett syndrome: clinical review and genetic update. J Med Genet 2005:42:1-7.

7. Miltenberger-Miltenyi $G$, Laccone F. Mutations and polymorphisms in the lnuman methyl CpG-binding protein MECP2. Hum Mut 2003;22:107-115.

8. Moog U, Smeets EEJ, van Roozendaal KEP, Schoenmakers $S$, Herbergs J, Schoonbrood-Lenssen AMJ, et al. Neurodevelopmentall disorders in males related to the gene causing Rett syndrome in females (MECP2). Eur J Paed Neurol 2003;7:5-12.

9. Couvert P, Bienvenu T, Aquaviwa C, Poirier K, Moraine C, Gendrot C, et al. MECP2 is highly mutated in X-linked mental retardation. Hum Mol Genet 2001;10:941-946.

10. Ylisaukko-Oja T, Rehnstrom $K$, Vanhala R, Kempas E, von Koskull $H$, Tengstrom $C$, et al. MECP2 mutation aralysis in patients with mental retardation. Am J Med Genet 2005; 132A:121-124.

11. RettBASE: The IRSA MECP2 variation database. Western Sydney Genetics Program, Children's Hospital, Westmead, NSW Australia; 2002.

12. Kriaucionis $\mathrm{S}$, Bind $\mathrm{A}$. The major form of MeCP2 has a novel $\mathrm{N}$-terminus generated by alternarive splicing. Nucleic Acids Res 2004;32:1818-1823.

13. Mnatzakanian GN, Lohi H, Munteanu I, Alfred SE, Yamada T, MacLeod PJM, et al. A previously unidentified MECP2 open reading frame defines a new protein isoform relevant to Reti syndrome. Nat Genet 2004;36:339-341.

14. Amir RE, Fang P, YuZ, Glaze DG, Percy AK, ZoghbiHY, et al. Mutations in exon 1 of MECP2 are a rare cause of Rett syndrome. J Med Genet 2005;42:e15.

15. Evans JC, Archer HL, Whatley SD, Kerr A, Clarke A, Butler R. Variation in exon 1 coding region and promoter of MECP2 in Rett syndrome and controls. Eur I Hum Genet $2005 ; 13: 124-126$. 
16. Poirier $\mathrm{K}$, Francis F, Hamel B, Moraine C, Fryns JP, Ropers $\mathrm{HH}$, et al. Mutations in exon 1 of MECP2B are not a conmon cause of $X$-linked mental retardation in males. Eur J Hum Genet 2005; 13:523 524.

17. Buschdorf $\mathrm{JP}$, Stratling WH. $A W W$ domain binding region in methyl-CpG-binding protein MeCP2: inpact on Rett syndrame: J Mol Med 2004:82:135-143.

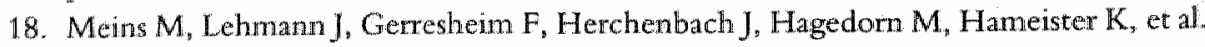
Subrictoscopic duplication in Xq28 causes increased expression of the MECP2 gene in a boy with severe mental retardation and features of Rett syndrome. J Med Genet 2005;42:e12.

19. Yntena HG, Kleefstra T, Oudakker AR, de Vries BBA, Nillesen W, Sistermans EA, et al. Low frequency of MECP2 mutations in mental retardation of unknown origin: implications for routine DNA diagnostics. Eur $\mathbb{J}$ Hum Genet 2002a;10:487-490.

20. Yrtema HG, Oudakker AR, Kleefstra T, Hamel BCJ, Bokhoven HV, Chelly J, et al. Inframe deletion in MeCP2 causes mild nonspecific mental retardation. Am J Med Genet $2002 b ; 107: 81-83$.

21. Watson P, Black $G$, Ramsden $S$, Barrow $M$, Super $M$, Kerr B, et al. Angelman syndrome phenotype associated with mutations in $\mathrm{MeCP} 2$, a gene encoding a methyl $\mathrm{Cp} G$ binding protein. J Med Genet 2001;38:224-228.

22. Turner $\mathrm{H}$, MacDonald $F$, Warburton $\mathrm{S}, \mathrm{Latif} F$, Webb $\mathrm{T}$. Developmental delay and the methyl binding genes. J Med Genet 2003;40:e13.

23. Scanlon R, Friez M. MECP2 mutations found in patients initially referred for Angelman syndrome testing. Proc Greenwood Genet Center 2004;23:46-51.

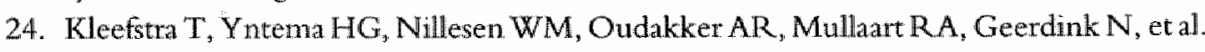
MECP2 analysis in mentally retarded patients: implications for routine DNA diagnostics. Eur ] Hum Genet 2004;12:24-28.

25. Hitchins MP, Rickard S, Dhalla F, Vries BBA de, Winter R, Pembrey M, et al. Investigations of UBE3A and MECP2 in Angelman syndrome (AS) and patients with features of AS. Am J Med Genet 2004;125A:167-172.

26. American Psychiatric Association. DSM-IV, Diagnostic Criteria. Washington, DC: APA, 1994. p 39-46.

27. Vourc"h P, Bienvenu 'T, Beldjord C, Chelly J, Barthelemy C, MuhJP, et al. No mutations in the coding region of the Rete syndrome gene MeCP2 in 59 autistic patients. EurJ Hum Genet 2001;9:556-558.

28. Beyer KS, Blasi F, Bacchelli E, Klauck SM, Maestrini E, Poustka A. International Molecular Genetic Study of Autism. Consortium (IMGSAC). Mutation analysis of the coding sequence of the MECP2 gene in infantile autism. Hum Genet 2002;111:305-309.

29. Lobo-Menendez F, Sossey-Alaoui K, Bell JM, Copeland-Yates SA, Plank SM, Sanford $\mathrm{SO}$, et al. Absence of MeCP2 mutations in patients from the South Carolina autism project. An J Med Genet 2003;117B:97-101.

30. Kammoun F, Roux $N$ de, Boespflug-Tanguy $O$, Vallée $L$, Seng $\mathbb{R}$, Tardieu $M$, et al. Screening of MECP2 coding sequence in patients with phenotypes of decreasing likelihood for Rett syndrome: a cohort of 1711 cases. J Med Genet 2004;41:e85. 
31. Carney RM, Wolpert CM, Ravan SA, Shahbazian M, Ashley-Koch A, Cuccaro ML, et al. Identification of MeCP2 mutations in a series of females with autistic disorder. Pediatr Neurol $2003 ; 28: 205-211$.

32. Kudo S, Nomura Y, Segawa M, Fujita N, Nakao M, Hammer S, et al. Functional characterisation of MeCP2 mutations found in male patients with $X$ linked mental retardation. Med Genet 2002;39:132-136.

33. Kudo S, Nomura $Y$, Segawa M, Fujita N, Nakao M, Schanen C, et al. Heterogeneity in residual function of $\mathrm{MeCP} 2$ carrying missense mutations in the methyl $\mathrm{CpG}$ binding domain. J Med Genet 2003;40:487-493.

34. Laccone F, Zoll B, Huppke P, Hanefeld F, Pepinski W, Trappe R. MECP2 gene nucleotide changes and their pathogenicity in males: proceed with caution. I Med Genet $2002 ; 39: 586-588$.

35. Orrico A, Lam C, Galli L, Dotti MT, Hayek G, Tong SF, et al, MeCP2 mutation in male patients with non-specific X-linked mental retardation. FEBS Lett 2000;481:285-288.

36. Dotti MT, Omico A, De Stefano N, Battisti C, Sicurelli F, Severi $S$, et al. A Rett syndrome MECP2 mutation that causes mental retardation in men. Neurology 2002; $58: 226-230$.

37. Klauck SM, Lindsay S, Beyer KS, Splitt M, Burn J, Poustka A. A mutation hot spot for nonspecific $X$-linked mental retardation in the MECP2 gene causes the PPM-X syndrome. Am J Hum Genet 2002;70:1034-1037.

38. Winnepenninckx B, Erriggers V, Hayez-Delatte F, Reyniers E, Frank Kooy R. Identification of a family with nonspecific mental retardation (MRX79) with the A140V mutittion in te MECP2 gene: is there a need for routine screening? Hum Mutat 2002;20:249252.

39. Gomot M, Gendrot C, Verloes A, Raynaud M, David A, Yntema HG, et al. MECP2 gene mutations in non-syndromic $X$-linked mental retardation: phenotype-genotype correlation. Am J Med Genet 2003;123A:129-139.

40. Gendrot C, Ronce N, Raynaud M, Ayrault AD, Dourlens J, Castelnau P, et al. X-linked nonspecific mental retardation (MRX16) mapping to distal $X_{\mathrm{q}} 28$ : linkage study and neuropsychological data in a large family. Am J Med Genet 1999;83:411-418.

41. Ravn K, Nielsen JB, Uldall P, Hansen FJ, Schwatz M. No correlation between phenotype and genotype in boys with a truncating MECP2 mutation. I Med Genet 2003;40:e5.

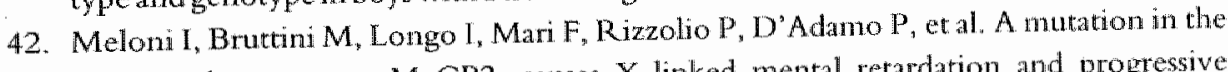
Rett syndrome gene, MeCP2, causes $X$-linked mental retardation and progressive spasticity in males. Am J Hum Genet 2000;67,982-985.

43. Claes $S$, Devriendt K, D'Adamo P, Meireleire J, Raeymaekers P, Toniolo D, et al. Xlinked severe mental retardation and a progressive neurological disorder in a Belgian family: clinical and genetic studies. Clin Genet 1997;52:155-161.

44. Kleefstra $T$, Yutema HG, Oudakker AR, Romein T, Sistermans $E$, Nillessen $W$, et all Denowo MECP2 frameshift mutation in a boy with moderate mental retardation, obesity and gynaecomastia. Clin Genet 2002;61:359-362. 


\section{METABOLIC STUDIES}

To test or not to test? Metabolic testing in mentally retarded adolescent and adult patients 149 
$14 \mathrm{~g}$ CHATER 
6. To test or not to test? Metabolic testing in mentally retarded adolescent and adult patients

\author{
Ute Moog ${ }^{\mathrm{a}, \mathrm{b} \star}$, Christine de Die-Smulders ${ }^{\mathrm{a}, \mathrm{b}}$, Herman Martens ${ }^{*}$, \\ Connie Schrander-Stumpel, ${ }^{\mathrm{a}, \mathrm{b}}$ and Leo Spaapen ${ }^{\mathrm{a}}$
}

"Department of Clinical Genetics, University Hospital Maastricht, and "Research Institute Growth \& Development (GROW), Maastricht Uniwersity, Maastricht, "The Netherlands 


\section{ABSTRACT}

Metabolic disorders are responsible for only a small fraction of mental retardation (MR), in particular in adolescent and adult patients. Testing in a selected group of patients has therefore been strongly recommended, and criteria for testing have been formulated repeatedly. On the other hand, knowledge on inborn errors of metabolism associated with MR has increased remarkably, and has delineated a broad phenotypic spectrum including MR associated with neurologic signs, abnormalities on neuro-imaging studies, malformations and dysmorphism.

In order to evaluate the criteria for metabolic testing in adolescent and adult mentally retarded persons, we analysed retrospectively the outcome of metabolic investigations performed during a 10-year period in 256 mentally retarded persons aged 16 years or older from 245 families. All patients had been carefully clinically evaluated. Testing included in most cases screening for congenital disorders of glycosylation (CDG), and for defects in cholesterol biosynthesis (e.g. Smith-Lemli-Opitz syndrome, SLO) in 112 patients. In 13 patients from 10 families, a metabolic disorder explaining the MR was found: homocystinuria $(N=1)$, galactosemia $(N=1)$, phenylketonuria $(N=2$, from the same family), Sanfilippo type A $(N=1)$, Sanfilippo type $B(N=3)$, SLO syndrome $(N=5$, from 3 families). The respective diagnosis was suspected on clinical grounds in $4 / 10$ index patients; 5 further index patients fulfilled one or several criteria for targeted metabolic testing. One diagnosis (homocystinuria) would have been missed if clinical selection had been performed. Regression, neurodegenerative signs, behavioral problems, or a sibling with the same condition and/or consanguinity, were important indicators for an underlying metabolic defect. We propose an adlapted list of clinical findings which may indicate the need for metabolic testing in adolescent and adult mentally retarded persons.

Keywords: mental retardation; metabolic testing 


\section{INTRODUCTION}

For several reasons, it is difficult to estimate the proportion of mental retardation (MR) which is due to inborn errors of metabolism. In different studies, there is no uniform set of detectable metabolic diseases as both the definition of metabolic diseases, as well as the screening protocols for their detection, differ. Studies on the etiology of MR do not always comprise a separate category for metabolic disorders, but include them in categories such as single gene or neurodegenerative disorders, or do not even mention them at all. In addition, disorders only possibly related to MR may or may not be included in the yield of metabolic testing.

Despite these limitations, Curry et al. [4] concluded in their review that $0-5 \%$ of MR are due to metabolic conditions; the study with the highest yield of $5 \%$ however, was based on a relatively small pediatric population (60 children) and included entities with uncertain relationship to MR [14]. Allen and Taylor [2] found in their large population based South Carolina study which included all ages, that metabolic disorders explain MR in $0.8 \%$ of cases. Van Karnebeek et al. [28] found a mean yield of $1 \%$ in a literature review of metabolic studies, and admitted that much higher figures can be found in specific, e.g. highly inbred, populations. Shevell et al. [22] evaluated metabolic studies involving pediatric populations with developmental delay, and found a similar yield of about $1 \%$ in the largest studies using non-selective screening protocols. The overall conclusion is that metabolic disorders constitute only a small fraction of the causes of MR. This proportion may even be less than $1 \%$ in adolescent and adult patients as inborn errors of metabolism most often present in infancy and childhood, and are associated with increased mortality early in life. Furthermore, neonatal screening programs for metabolic disorders increasingly led to the early detection of various conditions, and thus to a decrease of these diagnoses later in life.

Because of the low yield of metabolic testing and in addition, a high frequency of non-specific, non-diagnostic abnormalities necessitating further evaluation but not resulting in a clear diagnosis, testing in a selected group of patients has been strongly recommended for all ages [4]. This has been confirmed by Van Buggenhout et al. [26] for adult patients witl. MR; they screened 306 adult, institutionalized patients, and diagnosed metabolic disorders explaining the MR in four cases, but found in 40 patients metabolic abnormalities of unknown significance. Curry reinforced the need for focused testing on the basis of history, on on physical, neurologic and behavioral assessments, including a MRI of the brain, also in adolescents [5].

Despite a low yield, metabolic testing may however have large implications for the patients and their families [10]. Metabolic conditions may be potentially preventable, or amenable to treatment. As with other secure diagnoses, there is 
also an immediate impact on genetic counselling. Another point of consideration is that the knowledge on inborn errors of metabolism associated with MR, has increased considerably. A surprisingly broad phenotypic spectrum has been delineated, including MR associated with neurologic signs, abnormalities on neuroimaging studies, congenital malformations, and dysmorphism [10]. The question arises as to whether a focused testing procedure relies on a sufficient number of signs which indicate a possible metabolic defect.

After some surprising metabolic diagnoses in adolescent and adult mentally retarded patients, we decided to analyse retrospectively the outcome of metabolic investigations performed over a 10-year period in mentally retarded persons aged 16 years or older. In particular, we were interested in the criteria which led to the tests, and in the clinical presentation at the time of diagnosis.

\section{MATERIAL AND METHODS}

\section{Patients}

Between 1994-2003, a metabolic testing was performed in 256 patients from 245 families with unexplained MR. The patients included in the study were 16 years or older, with a mean age of 43.5 years. 120 patients were females and 136 were males. 26 of the 245 index patients had a brother or sister with the same disorder, consangunity was documented in three families. All patients lived in the south of the Netherlands, $92 \%$ of them in different institutions for the mentally retarded. The degree of MR was mild in 29 , moderate in 61 , severe or profound in 150 , and not further specified in 16 patients. The history of 35 patients reported regression in childhood or later in life. 63 of 256 patients showed severe behavioral problems, 22 had a psychiatric disorder, and 20 patients were reported to have autism; in 10 of these 20 patients, MR and autism were the only features. 71 of 256 patients had seizures, eight showed ataxia and 12 other neurologic features possibly indicating a metabolic disorder, such as hypotonia or parkinsonism. The following eye features possibly related to metabolic disorders were found: cataracts in 10 of 256 patients, retinal abnomalities in five and ophthalmoplegia in one patient. Bone abnormalities in two patients and ichthyosis in one patient were further indicators for metabolic testing. To establish an etiological diagnosis, all patients had undergone a careful clinical investigation. This included physical examination by a clinical geneticist, assessment of the family history whenever possible, cytogenetic analysis, and FMR 1 (Fragile X Mental Retardation 1) gene analysis in most cases. In none of the patients, a metabolic disorder had been diagnosed previously. During the period under investigation, clinical criteria for testing had not been formally assessed. In general, metabolic screening had been 
performed because of a clinical suspicion that a specific disorder existed, or was based on signs possibly indicating a metabolic disorder (targeted testing). A small subgroup of 38 patients had been tested without clinical preselection (unselected screening).

\section{Methods}

The programme for metabolic screening of patients with MR in the period 1994 -2003 comprised investigation of random urine and plasma samples according to standard procedures (Table I). $229 / 256$ patients were also investigated for congenital disorders of glycosylation (CDG) and 112 patients for abnormalities in cholesterol biosynthesis after introduction of the analysis of sterols in 1998.

Table I. Analytical programme for selective metabolic screening (1994-2003)

\begin{tabular}{ll} 
Urine & Method \\
\hline Group screening tests & Ion-exchange chromatography \\
Amino acids & GC-MS \\
Alditols/monosaccharides & RP-HPLC \\
Indoles/phemolic metabolites & DMB assay; electrophoresis \\
Mucopolysaccharides & TLC \\
Oligosaccharides & GC-MS \\
Orgarnc acids & RP-HPLC \\
Purine/pyrimidine bases and nucleosidies & RP-HPLC \\
Sialic acid &
\end{tabular}

\begin{tabular}{|c|c|}
\hline Assay & Mertaod \\
\hline Amino acids & Ion-exchange chromatograptry \\
\hline Total homorysteme & $\mathrm{RP}-\mathrm{HP} \mathrm{LC}_{\mathrm{C}}$ \\
\hline Sialic acid & RP-HPLC \\
\hline Sterols & GCMLS \\
\hline Very long chan fatty acids & GC-MS \\
\hline Sialotmansfernins & $\mathbb{L E F}$ \\
\hline
\end{tabular}

Legends: DMB: dimethyl-methylene blue spectrofotometric assay, GC-MS: gas-chromatographymmass spectroscopy. IEF: iso-electric focusing, RP-HPLC: rewersed-phase high-performance liquid chromatograpy, TLC: thin-layer chromarography 


\section{RESULTS}

In 13/256 patients from ten families, a metabolic disorder which caused their MR could be diagnosed: homocystinuria $(\mathrm{N}=1)$, galactosemia $(\mathrm{N}=1)$, phenylketonumia (PKU) $(\mathbb{N}=2$, both from the same family), Sanfilippo type $A(N=1)$, Sanfilippo type B $(N=3)$, and SLO syndrome $(N=5$, from 3 families). Diagnoses of a metabolic disease unrelated to MR, e.g. hypercholesterolemia, have not been included. Numerous other anomalies have been found on a first metabolic investigation which however, could not be confirmed on further examination. In four of these cases, further analysis was not possiblle, and thus we cannot exclude that one or several of these patients also suffered from a metabolic disorder. These cases , however, have also been left out of consideration.

The clinical data of the ten index patients are summarized in Table II.

In patient 1 , a first metabolic testing was performed elsewhere in infancy because of developmental delay, feeding problems and hepatic dysfunction. However, galactosemia was not identified, and only an unexplained increase of several amino acids was detected. As the exact screening protocol was unavailable, the reason for this negative result is unknown. On examination at age 16 years, Angelman syndrome was primarily suspected, based on the clinical signs. Methylation defects of chromosome region 15q11-13 were ruled out. A metabolic screening was initiated because of the combination of MR with epilepsy and unexplained liver disease, and showed increased excretion of galactose and galactitol. Subsequent enzyme investigation indicated galactose-1-phosphate uridyl-transferase (GALT) deficiency [27]. The diagnosis of classic galactosemia was confirmed by DNA analysis which showed compound heterozygosity for two GALT mutations. A galactose-restricted diet was started to ameliorate further progression. Ophthalmologic examination revealed no cataracts.

In patient 2 , a metabolic testing was done because of an unexplained MR syndrome and a brother presenting with the same features. PKU was diagnosed in both. In retrospect, the clinical features of both brothers, i.e. MR, microcephaly, fair hair, blue eyes, were consistent with a PKU phenotype, but in the beginning had not been recognized as such. A low phenylalanine diet was initiated in both individuals.

Patient 3 did not show any sign indicative for a metabolic condition in general (Table Ill), or for homocystinuria in particular. She had moderate MR and hypermetropia without further eye features, a length of $163 \mathrm{~cm}$ and weight of 69 $\mathrm{kg}$ with truncal obesicy, and was tested unselectedly. Homocystinuria was detected by increased urinary excretion of homocystine, strongly increased total homocysteine in plasma and slightly increased plasma methionine.

In patient 4, Sanfilippo syndrome (mucopolysaccharidosis type III, MPS III) was suspected because of severe behavioral problems, coarse facial features, 
macrocephaly, short broad hands, and the patient's history (see Table II). Urinary mucopolysaccharides in this patient were strongly increased. On the electrophoretic pattern heparansulfate was present as predominant fraction. Sanfilippo A (MPS IIIA) was confirmed by a strongly decreased activity of heparan $N$-sulfatase in leucocytes and skin fibroblasts.

In patients 5-7, obvious regression in childhood or young adulthood, and the combination of MR with behavioral problems prompted a metabolic screening. In all three cases, the urinary excretion of mucopolysaccharides was increased, with increased heparansulfate as assessed by electrophoresis. The diagnosis Santilippo type $\mathrm{B}$ was confirmed by severely deficient activity of alpha- $\mathrm{N}$-acetylglucosaminidase in plasma, leucocytes and cultered fibroblasts.

Patients $8-10$ were all severely mentally retarded and showed clinical signs pointing to the diagnosis of SLO syndrone, e.g. 2-3 syndactyly of the toes, short stature, severe genital anomalies, microcephaly, facial dysmorphism and lighthypersensitivity of the skin. Patient 8 and his brother have been published previously $[6,7]$. In all patients, severely decreased cholesterol levels and increase of the cholesterol precursors 7-and 8-dehydro-cholesterol were assessed. The diagnosis was confirmed by severely decreased activity of 7-dehydrocholesterol reductase in fibroblasts, and by DNA-analysis which showed compound heterozygosity for two mutations in the DHCR7 gene in all three patients.

\section{DISCUSSION}

We evaluated the outcome of metabolic testing in 256 patients from 245 families (age $=16$ years) with unexplained MR. In particular, we analysed the clinical pictures and the circumstances that had led to testing of the index patients.

Relatively few classic metabolic diseases can be associated with a clinically recognizable phenotype in adulthood, e.g. SLO syndrome, several types of mucopolysaccharidoses (MPS), or untreated PKU. The majority of metabolic diagnoses however, is the result of metabolic testing, initiated because of one or several signs indicating the general need of metabolic investigations. Criteria for such testing have been formulated by a Consensus Conference of the American College of Medical Genetics [4, Table VI]; they partly refer to the pediatric situation, e.g. the failure of appropriate growth. Van Buggenhout et al. [26] in their study of adult mentally retarded patients concluded that, in addition to these criteria, behavioral or neurodegenerative problems or specific dysmorphic signs should prompt a metabolic testing. Curry emphasized the importance of neurologic and psychiatric symptoms, white matter abnormalities on MRI, or specific physical signs, as possible indicators for a metabolic disorder in the adolescents [5]. 


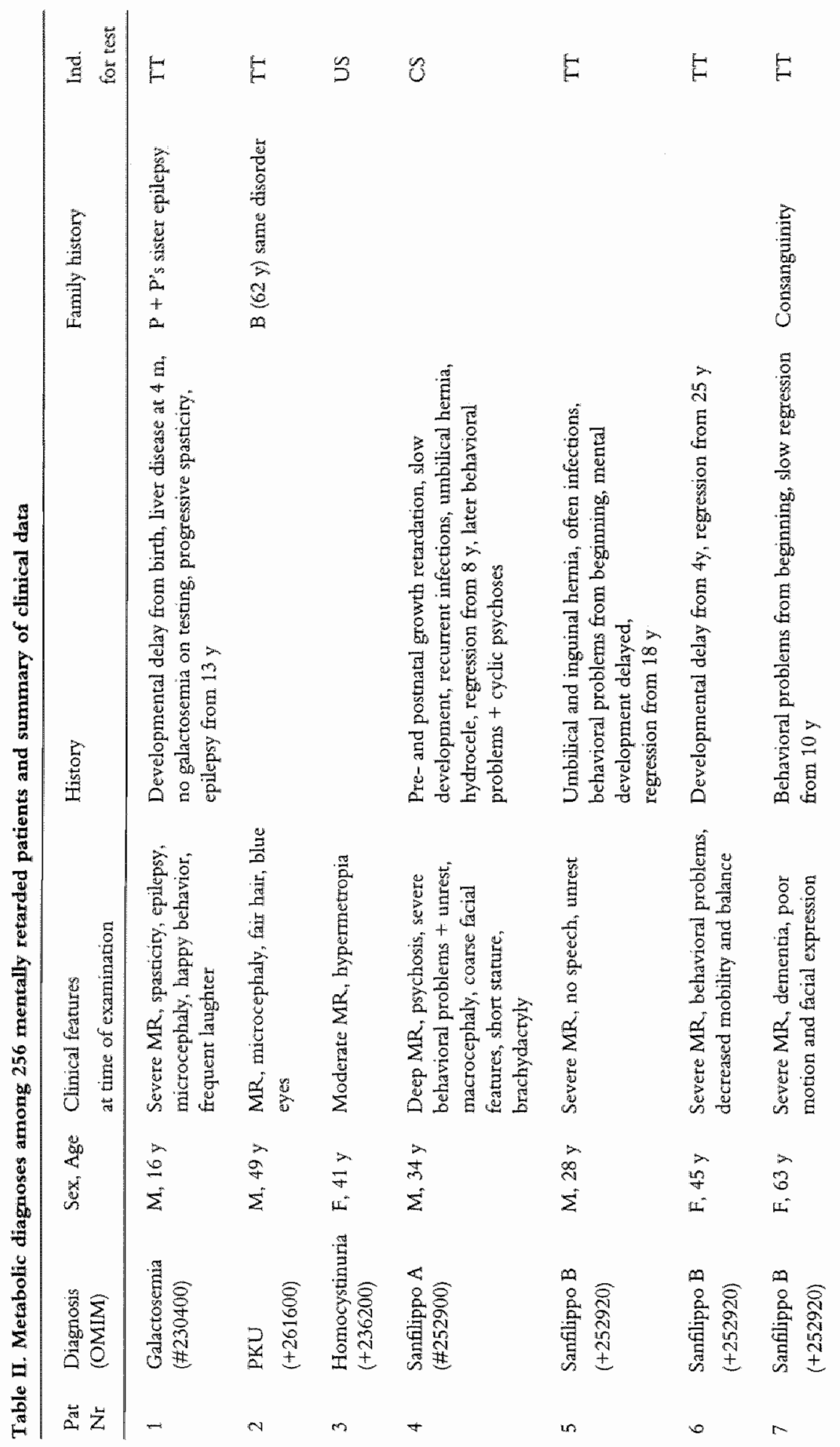




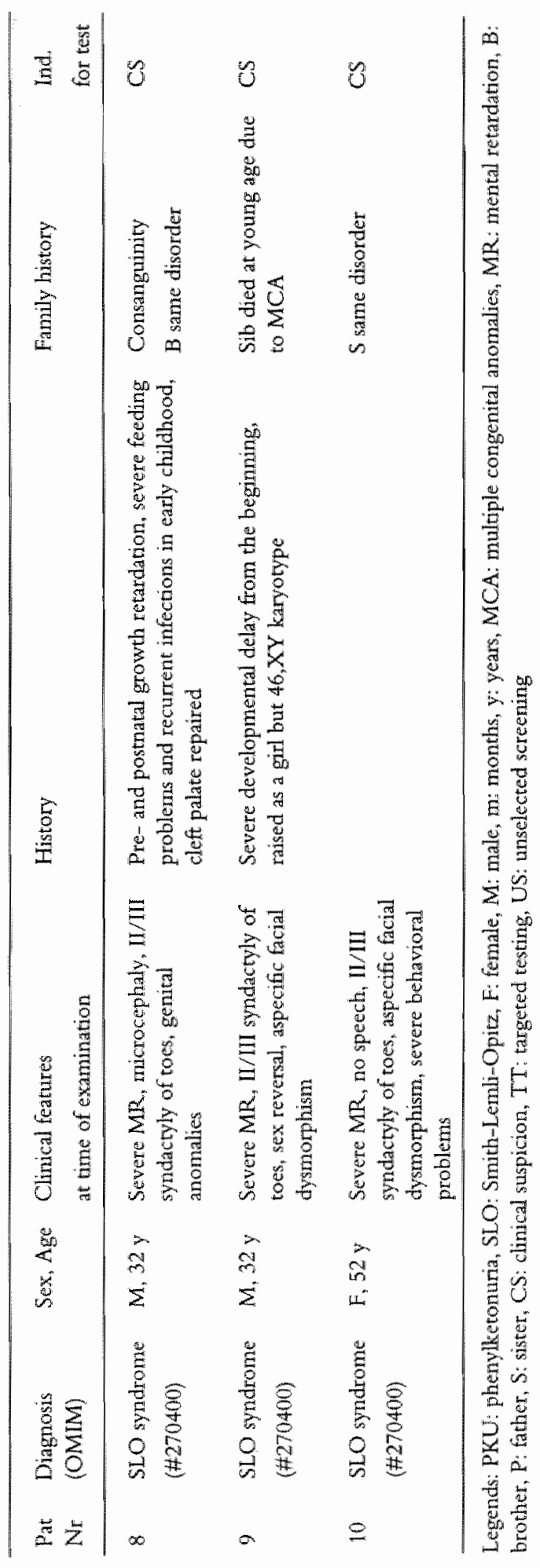


In the present study, inborn errors of metabolism which explained the $M R$, were diagnosed in 13 patients from ten families. The respective diagnosis was suspected on clinical grounds in $4 / 1,0$ index patients. Five further patients fulfilled one or several criteria for targeted metabolic testing as defined by the aforementioned Consensus Conference [4], or had a sibling with the same (unexplained) disorder. In concordance with Van Buggenhout et al. [26], in particular regression, neurodegenerative signs and behavioral problems were shown to be important indicators for underlying metabolic defects, furthermore a sibling with the same condition or consanguinity assessed in 2/10 families of our study. Based on the literature and our own experience, Table III proposes an adapted list of selected clinical findings urging the consideration of metabolic investigations in adolescent and adult patients with MR. One patient did not present any clinical sign indicating an inborn error of metabolism (patient 3 with homocystinuria, see below).

Table III. Selected dinical findings which may indicate the need of metabolic testing in adolescent and adult mentally retarded persons [adapted from Curry et al., 1997]

Loss of psychomotor skills, regression *, neurodegenerative signs*

Seizures, ataxa, hypotonia, recurren somnolence/coma

Serions behavional problems ${ }^{*}$, psychiatric signs*

Conese apperance

Hepatosplenomegaly

Eyye abnomalities (cataracts, ectopia lentis, ophthatmoplegia "corneal clouding, retinal abnomalities)

Skin abnonnalities (angiokeratoma, "orange-peel" skin, ichtyosis)

Bone aboormalities (dysostosis, occipical horns)

Arachnodactyly

Structural hair abnormalitics

Abnomal stomal differentiation

Unexplained deafoess. (with orser in childhoodt)

Sibling with similar tarares and/or consanguineous parents*

* Featura added to the Table by Curry et all [1997]

The diagnoses of this study included galactosemia, homocystinuria, phenylketonuria (PKU), Sanfilippo syndromes A and B, and Smith Lemli Opitz (SLO) syndrome; all of these are autosomal recessive conditions known to be frequently found among metabolic disorders associated with MR.

Classic galactosemia nomally presents in the neonatal period and if untreated, often leads to early death. Untreated survivors develop early cataracts, chronic liver disease, and MR [8]. Neonatal screening for galactosemia has been introduced in many countries in order to promote early treatment with galactose- 
restriction. However, long-term complications such as infertility, ataxia, a subtle decline in IQ, and speech abnormalities, have been frequently recognized even among well-treated individuals $[30,21]$. Discussions about the benefits of early diagnosis by newborn screening and on the cost efficiency of such a program is controversial $[3,19]$. In the Netherlands, newborn screening does not yet include galactosemia.

PKU is the prototype of preventable, genetic MR. A low phenylalanine diet and strict metabolic control throughout life lead to a normal or near-normal development (for recommendations of management, see [18] ). Newborn screening programs for the early detection of PKU have been established in most countries, in the US about 40 years ago and in Western Europe including the Netherlands in the $1970 \mathrm{~s}$. It has however to be born in mind that among adult and elderly mentally retarded persons, PKU may still be a relative frequent finding. Untreated individuals with PKU, in addition to MR as the clinical hallmark, can show seizures, behavioral problems and/or psychiatric pathology, microcephaly, eczema, a pale pigmentation, and a peculiar odor [20]. If PKU is diagnosed in previously untreated individuals, at least behavioral problems should prompt dietary treatment [18]. 30 to 40 years after the implementation of newborn screening, fetal damage due to maternal PKU may however become a more important issue of concern. Maternal PKU syndrome comprises MR, microcephaly, intra-uterine growth retardation and congenital heart malformation. For its prevention, careful metabolic monitoring before and during pregnancy is essential [18]. For untreated pregnancies, the risk of an affected child is greatly increased $[12,13]$.

The major clinical features of homocystinuria consist of $M R$, a characteristic Marfanoid habitus but with joint limitations and generalized osteoporosis, eye features such as ectopia lentis and myopia, and vascular problems [16, 17]. Psychiatric problems are seen in about $50 \%$ of patients [1]. However, clinical variability is well recognized with $I Q$ ranging from 10 to 135 , and about one third of patients have normal intelligence [17]. Homocystinuria may also present as aspecific MR as has been illustrated by patient 3 [17]. Thus, this diagnosis may only be established on systematic metabolic screening and can be missed if only targeted metabolic testing is performed.

Sanfilippo syndromes are characterized by severe involvement of the central nervous system leading to neurologic degeneration, behavioral problems, and mental decline; somatic fearures are relatively mild, in particular in Sanfillippo B which is the most common subtype of MPS in the Netherlands [29]. Possible somatic problems in adulthood are epilepsy, cardiomyopathy, arthritis, bullous skin lesions, and swallowing difficulties requiring feeding by a percutaneous endoscopic gastrostomy (PEG) tube. Compared to the other MPSIII types, the course of Sanfilippo B is protracted. Developmental delay and behavioural prob- 
lems are typically noted after $4-6$ years, cognitive decline is evident at 10 to 30 years, and paticnts between 20 to 40 years are characterized by severe $\mathrm{MR}$ and increasing behavioral problems. Loss of mobility may be seen late in adulthood. Sanfilippo A is more frequent in North Europe, and is characterised by a much earlier onset and a more rapid deterionation [27]. Due to the rather aspecific phenotype of, in particular, MPS IIIB, and the variability in expression, Sanfilippo syndromes may be underdiagnosed in the mentally retarded, or diagnosed only late in life as illustrated by patients $5-7$ [15].

SLO is characterized by recognizable craniofacial features in childhood, in addition to 2-3 syndactyly of the toes, genital anomalies in males, and mostly severe MR [11]. However, the facial appearance changes with age and is less characteristic in adulthood; a coarse face with broad alveolar ridges, large crowded teeth, and a bulbous nasal tip may be present. Patients are usually short statured and show a sunlight hypersensitivity. The genital anomalies in males may be less prominent or even disappear in adulthood [6]. Behavioral problems with self-injurious behavior are common [25]. Trials with a combination of a high cholsterol diet with statin treatment so far gave no convincing results [23].

During the past decade, a rapidly growing number of congenital disorders of glycosylation (CDG) have been identified. CDG cause a broad range of phenotypes, but usually present in childhood [9]. In the present cohort of patients aged 16 years or older, screening for CDG syndromes has been done on a large scale by isoelectric focusing of serum transferrin, but no patient was diagnosed with this disorder.

The discussed diagnoses have been assessed over a 10 year period during which the clinical criteria for testing have been inconsistent. It seems thus inappropriate to use the data to establish the prevalence of metabolic causes of MR in adolescent and adults. It should also be emphasized that metabolic diagnoses in adolescent or adult patients with MR who did not meet the general criteria for this study, e.g. who had not undergone an examination by a clinical geneticist, were not included. In general, neonatal screening programs will further decrease the number of adolescents and adults who present with unexplained MR due to an inborn error of metabolism. The advent of new analytical methods, in particular of tandem spectrometry, has revolutionized newborn screening and a wide range of disorders, in particular aminoacidemias and organic acidemias, are now diagnosed early in life. However, a non-uniform range of diseases is screened for in the different countries, and several of the diagnoses of the present study group (SLO, MPSIII) are not amenable to screening on blood spots. The diagnosis of metabolic disorders in adolescent and adult mentally retarded individuals thus remains a challenge. Once a diagnosis established by biochemical investigation, patients can be further evaluated for enzyme function, genotype or other factors possibly influencing the phenotype. Knowledge of both the natural history and adult 
phenotype of metabolic disorders, and of the underlying gene defect and pathophysiology will be necessary to promote the treatment of metabolic disorders.

In conclusion, most metabolic diagnoses, if not specifically suggested on clinical grounds, would have been established by screening in a selected group of patients. We therefore agree that metabolic testing should follow a targeted procedure. In view of the possible benefit of a diagnosis, however, we want to stimulate awareness of the broad spectrum of possible indicators, such as those listed in Table III, and strongly recommend to discuss patients with unexplained MR with a metabolic clinical specialist.

\section{REFERENCES}

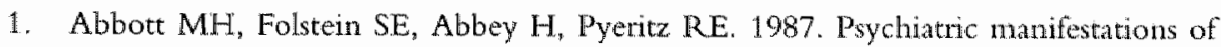
homocystinuria due to cystathionine beta-synthase deficiency: prevalence, natural history, and relationship to neurologic impaiment and vitamin B(6)-responsiveness. Am J Med Genet 26:959-969.

2. Allen WP, Taylor HA. 1996. Mental retardation in South carolina. VIY. Inborn errors of metabolisn. Proc Greenwood Genet Center 15:76-79.

3. Clague A., Thomas A. 2002. Neonatal biochemical screening for disease. Clin Chim Acta 315:99-110.

4. Curry CJ, Stevenson RE, Aughton D, Byme J, Carey JC, Cassidy S, CumniftC, Graham JM Jr, Jones MC, Kaback MM, MoeschlerJ, Schaefer GB, Schwartz S, Tarleton J, Opitz J. 1997. Evaluation of mental retardation: recommendations of a consensus conference. Am J Med Genet 72:468-477.

5. Curry CJ. 2002. Rational evaluation of the adolescent with mental retardation. Adolesc Med 13:331-3:43.

6. De Die-Smulders C, Fryns JP. 1992. Smith-Lemli-Opiz syndrone: the changing phenotype with age. Genet Couns 3:77-82.

7. De Die-Smulders CEM, Waterham HR, Fryns JP. 1999. Unexpected molecular findings in 2 previously described brothers with Smith-Lemlim Opitz syndrome. Genet Couns $10: 403$.

8. Holton JB, Walter JH, Tyfield LA. 2001. Galactosemia. In: Scriver C.R., Beaudet A.L., Sly W.S., Valle D. (Eds.), The metabolic and molecular bases of inherited disease, 8th Edn., McGraxw-Hill, New York, pp. 1553-1587.

9. Jaeken J, Carchon H. 2004. Congenital disorders of glycosylation (CDG): a booming chapter of pediatrics. Curr Opin Pediatr 16:434-439.

10. Kahler SG, Fahey MC. 2003. Metabolic disorders and mental retardation. Am J Med Genet $117 \mathrm{C}: 31-41$.

11. Kelley RI, Hennekan RC. 2000. The Smith-Lemli-Opitz syndrome. J Med Genet $37: 321-335$. 
12. Lenke RR, Levy HL, 1980. Matemal phenylketonuria and hyperphenylalaninemia. An international survey of the outcome of untreated and treated pregnancies. N Engl J Med 303:1202-1208.

13. Levy HL. 2003. Historical background for the matemal PKU syndrome. Pediatrics $112: 1516-1518$.

14. Majnemer A, Shevell M. 1995. Diagnostic yield of the neurologic assessment of the developmentally delayed child. J Pediatr 127:193-199.

15. Moog U, Schoonbrood-Lenssen AMJ. Wagemans A, Spapen LJM, de Die-Smulders CEM. 1998. De ziekte van Sanfilippo type B: ondergediagnostiseerd bij verstandelijk gehandicapten? Nederlands Tijdschrift voor de Zorg an verstandelijk gehandicapten 24:161-166.

16. Mudd SH, Skowby F, Levy HL, Pettigrew KD, Wilcken B, Pyeritz RE, Andria G, Boers GH, Bromberg IL, Cerone R, Fowler B, Grobe H, Schmidt H, Schweitzer L. 1985. The matural history of homocystinuria due to cystathionine beta-synthase deficiency. Am J Hum Genet 37;1-31.

17. Mudd SH, Levy HL, Kraus JP. 2001. Disorders of transsulfuration. In: Scriver C.R., Beaudet A.L., Sly W.S. Valle D. (Eds.), The metabolic and molecular bases of inherited disease, 8th Edn., McGraw-Hill, New York, pp. 2007-2056.

18. National Institutes of Health Consensus. Development Panel. 2001. National Institutes of Health Consensus Development Conference Statement: phenylketonumia: screening and management, October 16-18, 2000. Pediatrics 108:972-982.

19. Schweitzer-Krantz S. 2003. Early diagnosis of inherited metabolic disorders towards improving outcome: the controversial issue of galactosaemia, Eur J Pediatr 162 (Suppl 1): $\$ 50-53$.

20. Scriver CR, Kaufman S. 2001. Hyperphenylalaninemia: phenylalanine hydroxylase deficiency. In: Scriver CR, Beaudet AL, Sly WS, Valle D (Eds.). The metabolic and molecular bases of inherited disease, 8th Edn., McGraw-Hill, New York, pp. 1667-1724.

21. Segal S. 1998. Galactosemia today: the enigmand and the challenge. J Jnherit Metab Dis $21: 445-471$.

22. Shevell M, Ashwal S, Donley D, Flint J, Gingold M, Hirtz D, Majnemer A, Noetzel M, Sheth RD; Quality Standards Subcommittee of the American Academy of Neurology; Practice Committee of the Child Neurology Sociery. 2003. Practice parameter: evaluation of the child with global developmental delay: report of the Quality Standards Subcommittee of the American Academy of Neurology and The Practice Committee of the Child Neurology Society. Neurology 60:367-380.

23. Sikora DM, Ruggiero M, Petit-Kekel K, Merkens LS, Connor WE, Steiner RD. 2004. Cholesterol supplementation does not improve developmental progress in Smith-LemliOpitz syndrome. I Pediatr 144:783-791.

24. Spaapen LJM, Bakker JA, Moog U, Rubio ME, Forget PP. 2000. Delayed diagnosis of galactosemia in a severely retarded boy. I Inherit Metab Dis 23(Suppl 1):157. 
25. Tieney E, Nwokoro NA, Porter FD, Freund LS, Ghuman JK, Kelley R I 2001, Behavioural phenotype in the RSH/Smith-Lemli-Opitz syndrome. Am J Med Genet 98:191200.

26. Van Buggenhout GJCM, Trijbels JMF, Wevers R, Trommelen JCM, Hamel BCJ, Brunner HG. Fryms JP. 2001. Metabolic studies in older mentally retarded patients: significance of metabolic testing and correlation with the clinical phenotype. Genet Counsel 12:1-21.

27. wan de KampJJP, Niermeijer MF, von Figura K, Giesberts MAH. 1981. Genetic heterogeneity and clinical variability in the Sanfilippo syndrome (types A, B, and C). Clin Genet 20:152-160.

28. Van Karnebeek CD, Jansweijer MC, Leenders AG, Offinga M, Hennekam RC. 2005. Diagnostic investigations in individuals with mental retardation: a systematic literature review of their usefulness. Eur J Hum Genet 13:6-25.

29. van Schrojenstein-de Valk HM, van de Kamp IJ. 1987. Follow-up on seven adult patients with mild Sanfilippo B-disease. Am J Med Genet 28:125-129.

30. Waggoner DD, Buist NRM, Donnell GN. 1990. Long-term prognosis in galactosemia: results of a survey of 350 cases. J Inherit Metab Dis 13:802-818. 



\subsection{BENEFIT OF GENETIC EVALUATION OF MENTAL RETARDATION}

This thesis is dealing with a number of clinical and laboratory diagnostic investigations in MR, and their yield. A consideration of the benefits of evaluations of $M R$ seems equally important.

The central issue of the genetic evaluation of MR is its causality. Once a causal diagnosis has been established, questions regarding its clinical presentation, pathogenesis, management, prognosis, recurrence risk, and possibly even its prevention can (partly) be answered. In other terms, answers to the most important questions of the parents, or other family members, and of care providers can be given appropriately. The enormous benefit of a causal diagnosis has frequently been addressed (among others by Curry et al.,1997, Wilska and Kaski, 2001, and Alexander, 2002). According to this literature and to this thesis, the most important aspects will be briefly addressed:

Establishing a diagnosis in the very first place means giving an answer to the most burming question: what does he/she have? Giving the ,what" a name means making things clear, means a release from uncertainty, and means having the power of knowledge (see below: what's in a name?). In general, a causal diagnosis also permits conclusions about causation and pathogenesis, and thus it permits answers to the second question: why did it happen? Not infrequently, wrong admissions, in particular those regarding possible teratogenic effects and traumatic events during pregnancy, and the effects of perinatal distress, can be corrected. Sometimes a guilt feeling may disappear.

Multiple questions regarding management and prognosis focus on: what does this diagnosis mean to my child (brother/sister)? In a growing number of genetic syndromes, management guidelines are avalable, often via the intemet. They are edited for the most common syndromes as practical one-volume books (e.g. Wilson and Cooley, 2000; Cassidy and Allanson, 2005). They contain information on medical complications and their prevention, as well as schemes for regular follow-up; a summary of the natural history, and in addition, short-term and long-term prognoses are given. Furthemore, in an increasing number of cases, knowledge about developmental profiles and behavioral patterns can be translated into an adapted psycho-social care. Patient support groups provide further information. They facilitate the contact between families in order to let them share their experiences and knowledge, and to give the opportunity to address open questions. For the Dutch situation, the reader is referred to the websites of the Federation of Dutch organisations of parents of people with MR (Federatie voor Ouderverenigingen, www fvo.nl), of the Erfocentrum, a national information center (www.erfelijkheid.nl), and of the Dutch alliance of patient support groups (Vereniging Samenwerkende Ouder- en Patientenorganisaties, 
www.vsop.nl). In the absence of such a group, the clinical geneticist can help the family contact other families who have a member with the same condition. It also belongs to the tasks of the clinical geneticist to provide information on the syndrome in question, and on its management, to the care providers. For patients with specific, well-known syndromes, e.g. with Down, Prader-Willi or Rett syndromes, multidisciplinary teams offer their services in specialised out-patient clinics. There are thus numerous, non-exclusive ways to gain insight into a particular syndrome and to practice preventive management. The goal is to optimise care for a mentally retarded person, by appropriately responding to the special needs of a given diagnosis.

Questions regarding heritability and recurrence risk are addressed by the question: what does it mean to the family? Based on the diagnosis and its pattern of inheritance, a recurrence risk can be given, and the possibilities of prenatal diagnosis can be discussed. This is subject to genetic counselling, as well as alternative options of family planning. Investigation and counselling of family members can be initiated, e.g. in case of familial chromosome aberrations or X-linked forms of MR.

Issues of treatment and cure give rise to the question: is there anything one can do? So far, in most cases there is no cure, and treatment refers to symptoms as seizures or sleeping disorders, and not to the causes. The few exceptions are mainly metabolic disorders. As the efficiency of therapy crucially depends on a very early diagnosis, neonatal screening has been introduced in most countries for a varying number of metabolic disorders (see chapter 6); for future perspectives of the treatment of metabolic and other disorders see below.

What's in a name? Several of the above mentioned issues can only be addressed when a causal diagnosis with known etiology, impact on management and/or genetic background can be established; examples are Coffin-Lowry syndrome, velocardiofacial syndrome (deletion $22 \mathrm{q} 11.2$ ), and Smith-Lemli-Opitz syndrome. Sometimes however, information is very restricted as the diagnosis may be purely descriptive. This is true for a huge number of very rare syndromes with unknown inheritance which have been delineated on the basis of only a few cases. Surprisingly, it seems to be a general experience that even in these cases diagnosis has a beneficial effect. This effect can be observed even when the cause of a syndrome is unknown, when too few cases have been published to permit reliable information on management and prognosis, and when neither treatment nor prenatal diagnosis are available - even then, parents or family members feel relieved on hearing the diagnosis.

Obviously, giving a name to a disease or disorder has a beneficial effect which reaches far beyond its apparent consequences in terms of clinical management or family planning - an effect that in the author's opinion is universal and may be 
archaic. It might relate to what in philosophy and religion has been widely discussed as the mystery of naming someone or something: knowing the name of something or someone means having power over the person or the thing to be named ( $R G G, 1960)$. A name thus is much more than just a designation. It represents the identity of the thing in question, but it also defines our relationship to it. Interestingly, ethymologically the term "name" is one of the most archaic words of any language. The concept of the person's name as pars pro toto has a related origin, and was strong in archaic times and particularly during the Middle Ages. Hence a thing becomes real for us when we have given it a name-a diagnosis thus contributes to relieving the handicap of a child or sibling of its nebulosity and uncertainty, and permits it to enter a manageable reality.

In contrast to the beneficial aspects of a diagnosis the effects of an incorrect diagnosis are detrimental. Only definite diagnoses should be communicated as certain, provisional ones should be communicated clearly as only "possible" or "probable" (see chapter 2 ). When it is less likely that a person has a particular disorder than not having it, the prestimed, diagnosis" in general should not be mentioned at all, but only be kept in mind. The clinicians"s urge to establish a diagnosis at the end of a tiresome period of "unknowns" is understandable, but this should underscore the need for extra alertness about the probability of a diagnosis.

In conclusion, the benefits of genetic evaluation are evident, both for the person with $M R$, and for the family and care providers. As, in addition, clinical genetic investigations on the etiology of MR are not a heavy demand on the patient, every individual with $M R$ has the right to have a careful clinical genetic evaluation, at least once in her or his life.

\subsection{FUTURE PERSPECTIVES}

How will the genetic evaluation of MR evolve? What will be the chances and pitfalls of etiological studies on MR? Will growing possibilities present themselves in the advantage of the patient?

\section{Clinical evaluation}

In the clinical evaluation of a mentally retarded person, there will be both a greater need and chance for more systematic approaches. In chapter 3.1 , a classification of an extensive list of physical abnormalities proposed by Merks et al. (2003) was recommended for systematic use in the examination of individuals with $M R$. In 2004, Shalev and Hall offered a tool for the standardized description of behavioral 
profiles which can be integrated in the genetic work-up of any patient with MR. The proposed method of classification of the causes of MR (chapter 2) is meant to contribute to the general need of classification systems in the field. All these tools can be used to register patients with MR systematically in order to facilitate follow-up procedures, insight into pathogenesis and genotype-phenotype correlation studies. Registration databases should use the terminology of well established dysmorphology databases, e.g. the London Dysmorphology Database, permitting cross-link searches.

Elaborated data-bases in general are increasingly applied in the field of clinical evaluation of MR. They reflect the growing need of standardization, classification and cross-linking of results. Recently, it has been suggested to discontinue publication of case reports and to deposite them instead directly into databases (Biesecker, 2004). This would require the development of shared resources, agreements on confidentiality and, in particular, on standardization (Biesecker, 2004). The discussed problems of interpretation of subtle chromosome aberrations (see chapter 4.3 and 7.2 , below) will partly be resolved by the further devel opment of cytogenetic databases which include a thorough clinical description, as e.g. ECARUCA (European Cytogeneticists Asociation Register of Unbalanced Chromosome Aberrations). Mutation databases facilitating genotype-phenotype correlation have been established since a long time, e.g. the IRSA database for $M E C P 2$ mutations (see chapter 5.3).

\section{Genome analysis: cytogenetic and molecular analysis}

There is no doubt that new technologies that have been developed in recent years will be increasingly implemented in daily practice, and that these will probably change studies on the etiology of MR dramatically. The most important ones will be briefly discussed.

MAPH (multiple amplifiable probe hybridization) and MLPA (multiplex ligation-dependent probe amplification) are both techniques derived from FISH and PCR based (see chapter 4.1 and 4.3 ). They both use a set of specifically designed probes, each flanked by the same primer-binding sites, and hybridise it to the test DNA. Each probe can be subsequently identified and quantified in a single experiment (for review see Sellner \& Taylor, 2004). MAPH and MLPA allow the screening of multiple loci simultaneously for deletions and duplications, e.g. for all chromosome ends and/or for loci of frequently occurring microdeletion syndromes, or for all exons of a gene. Both are fast and simple methods with a high resolution and high throughput. It has been shown that they are useful for detecting both interstitial and subtelomeric imbalances in MR (Koolen et al., 2004; Kriek et al., 2004). Very probably these methods will rapidly further evolve 
as diagnostic tools, and will in particular be used to scan (simultaneously) for subtelomeric rearrangements and for known microdeletion/microduplication syndromes. They will increasingly replace FISH with a complete set of subtelomeric probes which is still the technique most often applied to screen for subtelomeric abnomalities (see chapter 4.3). Furthermone, targeted FISH with sequence specific probes, so far employed to confirm a particular clinical diagnosis, e.g. deletion $22 \mathrm{q} 11.2$, deletion $7 \mathrm{q} 11.2$ (Williams syndrome) or deletion $17 \mathrm{p} 11.2$ (Smith-Magenis syndrome), will increasingly be replaced by MLPA or MAPH screens for a whole series of microdeletions. HR-G banding will, however, still be the most widely used cytogenetic technique in routine and will remain the gold standard of initial chromosome analysis (Salman et al, 2004). It is well established in all laboratories, is able to screen all chromosomes entirely for both balanced and unbalanced abnormalities, and is able to detect mosaicism even at a low level (see chapter 4.1). Its disadvantages are the need for cell culture, its labour intensive methodology, its relatively long turn-around time, and its low resolution of $5-8 \mathrm{Mb}$.

Array-based technologies meanwhile have aquired major significance. Array CGH (Comparative Genomic Hybridization) allows genome-wide examination for copy number changes, i.e. even very small deletions and duplications, in a single experiment by comparing test (patient) DNA with reference (nomal) DNA. The metaphase chromosome spread of conventional CGH (see chapter 4.1) has now been replaced by an array of DNA clones on a chip (Pinkel et all., 1998). The resolution is greatly increased and depends on the distance between the selected DNA clones. Array CGH is fast and allows a very high tumover. It has been applied extensively in cancer genomics and has multiple other applications in clinical genetics (for review, see Oostlander et al, 2004). It can be performed on any sample which provides DNA, and no cell culture is needed. It has been introduced as a promising "rapid and sensitive automated diagnostic procedure" in the evaluation of patients with MR (Veltman et al., 2002) and has proven useful in the detection of submicroscopic imbalances (Vissers et al., 2003; Schoumans et al., 2004; Shaw-Smith et al., 2004). This technique has been used to prove that de now, apparently balanced, translocations are often unexpectedly much more complex rearrangements (Gribble et al., 2005). Its disadvantages are the very limited ability to detect mosaicism, and the difficulty to detect aberrations without copy number changes, e.g. de novo balanced translocations. For further comparison of array $\mathrm{CGH}$, and old and new cytogenetic techniques, the reader is referred to the review by Salman et al. (2004). The design, setup and validation of such arrays are however expensive and major technical challenges. Alternatives are publicly available arrays ("chips"), which have meanwhile also been developed at the level of single nucleotide polymorphisms. (SNPs). Array SNP has been 
developed very recently. It allows both genotyping and copy number analysis. The era of clinical application of array SNP in the etiological investigation of MR has just begun. A study using the GeneChip Mapping 10K SNP array demonstrates that deletions and duplications of about $5 \mathrm{Mb}$ can be reliably detected, but that smaller imbalances can be readily missed due to insufficient SNP density in the respective region ( $R$ auch et al., 2004). The resolution so far is not much better than that of HR chromosome banding, but it is only a question of time before SNP arrays with much higher resolution are available for the evaluation of MR. Array SNP is a very promising technology for detecting deletions and duplications and probably has the future.

Array based technologies are applicable not only for molecular karyotyping, but also for the study of any monogenic or polygenic condition. MLPA/MPAH and array-based technologies illustrate that the boundary between cytogenetics and molecular genetics have vanished, and that genome analysis nowadays is the more appropriate term to use.

Interpretation of results. The methods discussed above, and in particular array-based methods, comprise a major challenge: they will detect a growing number of copy number changes, deletions or duplications, of unknown significance. The interpretation will be based on segregation studies and literature reviews, but will often be hampered by the inaccessibility of family members for testing, or the existence of few (if any) published reports. Other complicating factors are the possible clinical variability known e.g. for many subtle chromosome aberrations (see chapter 4.3), and/or reduced penetrance. In every individual case, geneticists will have to proceed with caution, and not conclude too rapidly that e.g. a subtle deletion is pathogenic only because it has occurred de nowo. A yet unknown proportion of copy number changes will finally turn out to be polymorphisms.

In general, it can be predicted that data of possibly pathogenic significance will be created increasingly, but also that the subsequent interpretation will become a consuming demand upon geneticists. The correlation of subtle cytogenetic abnormalities with the phenotype will be very difficult, and often identifying a gene will be easier than determining the relationship between gene and disorder. The benefit of the evaluation of MR delineated above, however completely depends on the clinical applicability of the aquired information. Questions regarding management and prognosis can not be answered if they concern hitherto undescribed abnormalities, and neither genetic counselling of the family nor prenatal diagnosis can be reliably offered if there are doubts on the pathogenicity. 


\section{Metabolic investigations}

Two developments are likely to influence the yield of metabolic investigations contrarily. On the one hand, neonatal screening programs will increasingly identify children with metabolic disorders associated with developmental delay. As discussed in chapter 6 , this will lead to a decrease of the respective diagnoses later in life. Neonatal screening has evolved from the Guthrie test which tested for phenylketonuria (PKU) on blood spots on filter paper, to tandem mass spectroscopy which allows automated testing of a wide range of disorders, in particular of amino- and organic acid metabolism. Since the advent of tandem mass spectrometry and other analytical methods, a huge number of mostly very rare conditions is (theoretically) amenable to screening. In Western countries, PKU screening has been introduced throughout, apart from screening for congenital hypothyroidism $(\mathrm{CH})$ which is done by conventional techniques. Screening for other diseases however, e.g. galactosemia, aminoacidemias and organic acidemias, has been introduced in the different countries non-uniformly because cost-benefit analysis did not show unequivocal financial benefit (Clague and Thomas, 2002). Overall however, $\mathrm{PKU}$, gallactosemia and other metabolic disorders will be the vanishing diagnoses in the evaluation of $M R$.

On the other hand, new technologies have led to the detection of a bunch of new, previously unknown disorders. Creatine transporter deficiency was recently identified as an X-linked disorder and is associated with MR, epilepsy and autism, but possibly also with aspecific MR (Salomons et al., 2003); analysis is by tandem mass spectroscopy. Other examples are Walker-Warburg syndrome (WWS), muscle-eye-brain disease (MEB) and Fukuyama muscular dystrophy (FCMD) which are related syndromes with developmental delay, severe neurological features affecting the brain and/or muscles, and eye abnormlities. They were all shown to be caused by disturbances of $\mathrm{O}$-glycosylation, WWS by deficiency of O-mannosyltransferase encoded by POMT1 (Beltran-Valero de Bernabe et al., 2002), MEB by deficiency of a glycosyltransferase encoded by POMGnT1 (Yoshida et al., 2001), and FCMD by a defective phospholigand transferase encoded by the fukutin gene (Kobayashi et al., 1998). The confirming diagnosis, however, after neurological and metabolic work-up, is by DNA-analysis of the respective genes. This group of disorders illustrates that the link between metabolic investigations and genome analysis becomes increasingly important. They also urge the need for a close cooperation beween clinical geneticists, molecular geneticists, metabolic clinical specialists and neurologists. Predictably, this development will still continue and open a new field; these will be the raising diagnoses in the evaluation of MR. 


\section{From care to cure}

It is possible that some of the future (neuro)metabolic disorders will offer the possibiliy of treatment, as has already been shown for creatine synthesis defects which may show improvement by treatment with creatine monohydrate (van der Knaap et al., 2000). Recently, hypotheses on treatment have also emerged for some non-metabolic disorders. For fragile $\mathrm{X}$ syndrome, treatment with metabotropic glutamate receptor (mGluR) antagonists or lithium was shown to have positive effects in a Drosophila Fragile $\mathrm{X}$ model (McBride et al., 2005). For chromatin remodelling disorders, e.g. Rubinstein-Taybi syndrome, in vitro and in vivo studies on pharmacological histone deacetylases (HDAC) inhibition are subject to actual research (Langley et al., 2005). Both approaches have derived from research on the pathogenetic background, illustrating that research is needed for the longterm benefit of the patient. The clinical applicability, however, will probably not be shown in the near future.

\section{Conclusion}

It appears to the author that this thesis has been written at a turning-point of genetic evaluation of MR. In coming years, clinical geneticists working on the evaluation of $M R$ will have to achieve a difficult balance between understanding and applying new technologies, translating the results of these into information which is relevant for a mentally retarded person, and implementing it in patient care. To the author, the piece which links research to a better care for individuals with $M R$, still seems the most challenging one.

\section{REFERENCES}

Alexander DF. 2002. How research advances will affect persons with mental retardation and developmental disabilities in the 21st century. Proc Greenwood Genet Center 21:5-19.

Biesecker LG. 2004. Endangered species. Am J Med Genet 128A:429-430.

Beltran-Valero de Bernabe D, Currier S, Steinbrecher A, Celli J, van Beusekon E, van der Zwaag B, Kayserili H, Merlini L, Chitayat D, Dobyns WB, Comand B, Lehesjoki A-E, Cruces J. Voit T, Walsh CA, van Bokhoven H, Brunner HG. 2002. Mutations in the Omannosyltransferase gene POMT1 give rise to the severe neuronal migration disorder Walker-Warburg syndrome. Am J Hum Genet 71:1033-1043.

Cassidy SB, Allanson JE (Eds). 2005. Management of genetic syndromes, $2^{\text {nd }}$ Ed. Wiley-Liss, Hoboken, New Jersey.

Curry CJ, Stevenson RE, Aughton D, Byrne J, Carey JC, Cassidy S, CunniffC, Graham JM Jr, Jones MC, Kaback MM, Moeschler J, Schaefer GB, Schwartz S, Tarteton I, OpitzJ. 1997. 
Evaluation of mental retardation: recommendations of a consensus conference. An J Med Genet 72:468-477.

Gribble SM, Prigmore E, Burford DC, Porter KM, Ng BL, Douglas EJ, Fiegler H, Carr P, Kalaitzopoulos D, Clegg S, Sandstron R, Temple IK, Youings SA, Thonas NS, Dennis NR, Jacobs PA, Crolla JA, Carter NP. 2005. The complex nature of constitutional de novo apparently balanced translocations in patients presenting with abnormal phenotypes. J Med Genet 42:8-16.

van der Knaap MS, Verhoeven NM, Maaswinkel-Mooij P, Pouwels PJ, Onkenhout W, Peeters EA, Stockler-Ipsiroglu S, Jakobs C. 2000. Mental retardation and behavioral problems as presenting signs of a creatine synthesis defect. Ann Neurol 47:540-543.

Koolen DA, Nillesen WM, Versteeg MH, Merkx GF, Knoers NV, Kets M, Vermeer S, wan. Ravenswayj CM, de Kovel CG, Brunner HG, Smeets D, de Vries BB, Sistermans EA. 2004. Screening for subtelomeric rearrangements in 210 patients with unexplained mental retardation using multiplex ligation dependent probe amplification (MLPA). J Med Genet 41:892-899.

Kobayashi K, Nakahori Y, Miyake M, Matsumura K, Kondo-[ida E, Nomura $Y$, Segawa M, Yoshioka M, Saito K, Osawa M, Hamano K, Sakakihara $Y$, Nonaka I, Nakagome $X_{\text {, }}$ Kanazawa I, Nakamura Y, Tokunaga K, Toda T. 1998. An ancient retrotransposal insertion causes Fukuyana-type congenital muscular dystrophy. Nature 394:388-392.

Kriek M, White SJ, Bouma MC, Dawwerse HG, Hansson KB, Nijhuis JV, Bakker B, van Ommen GJ, den Dunnen JT, Breuning MH. 2004. Genomic imbalances in mental retardation. $\mathbb{M e d}$ Genet 41:249-255.

Langley B, Gensert JM, Beal MF, Ratan RR. 2005. Remodeling chronatin and stress resistance in the central nerwous system: histone deacetylase inhibitors as novel and broadly effective neuroprotective agents. Curr Drug Targets CNS Neurol Disord 4:41-50.

McBride SM, Choi CH, Wang Y, Liebelt D, Braunstein E, Ferreiro D, Sehgal A, Srwicki KK, Dockendorff TC, Nguyen HT, McDonald TV, Jongens TA. 2005. Pharmacological rescue of symaptic plasticity, courtship behavior, and mushroom body defects in a Drosophila model of fragile X syndrome. Neuron 45:753-764.

Merks JI-IM, van Karnebeek CDM, Caron HN, Hennekam RCM. 2003. Phenotypic abnormalities: terminology and classification. Am J Med Genet 123A:211-230.

Oostlander AE, Meijer GA, Ylstra B. 2004. Microarray-based comparative genomic hybridization and its applications in human genetics. Clin Genet 66:488-495.

Pinkel D, Segraves R, Sudar D, Clark S, Poole I, Kowbel D, Collins C, Kuo WL, Chen C, Zhai Y, Dairkee SH, Ljung BM, Gray, JW, Albertson DG. 1998. High resolution analysis of DNA copy number variation using comparative genomic hybridization to microarrays. Nat Genet 20:207-211.

Rauch A, Ruschendorf F. Huang J, Twatmann $U$, Becker C, Thiel C, Jones $K W$, Reis A, Numberg P. 2004. Molecular karyotyping using an SNP array for genomewide genotyping. J Med Genet $41: 916-922$.

RGG (Die Religion in Geschichte und Gegenwart), 3rd Ed, volume 4. 1960. Mohr JCB, Tubingen. 
RettBASE: The IRSA MECP2 variation database. 2002. Western Sydney Genetics Progran, Children's Hospital, Westmead, NSW Australia.

Salman M, Jhanwar SC, Ostrer H. 2004. Will the new cytogenetics replace the old cytogenetics? Clin Genet 66:265-275.

Salomons GS, van Dooren SJM, Verhoeven NM, Marsden D, Schwartz C, Cecil KM, DeGrauw TJ, Jakobs C. 2003. X-linked creatine transporter defect: an overview J Inherit Metab Dis 26:309-318.

Schoumans I, Anderlid BM, Blennow E, The BT, Nordenskjold M. 2004. The perfomance of CGH array for the detection of cryptic constitutional chromosome imbalances. \Med Genet 41:198-202.

Shalev SA. Hall JG. 2004. Behavioral pattem profile: a tool for the description of behavior to be used in the genetics clinic. Am I Med Genet 128A:389-395.

Shaw-Smith C, Redon R, Rickman $\mathbb{L}$, Rio M, Willatt L, Fiegler H, Firth $H$, Sarlaville D, Winter R, Colleaux I, Bobrow M, Carter NP. 2004. Microamay based comparative genomic hybridisation (array-CGH) detects submicroscopic chromosomal deletions and duplications in patients with learning disability/mental retardation and dysmorphic features. J Med Genet 41:241-248.

Sellner LN, Taylor GR. 2004. MLPA and MAPH: new techniques for detection of gene deletions. Hum Mutat 23:413-419.

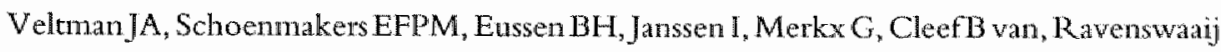
$\mathrm{CM}$ van, Brumner $\mathbb{H G}$, Smeets D, Kessel $A G$ van. 2004. High-throughput analysis of subtelomeric chromosome rearrangements by use of array-based comparative genomic hybridization. Am J Hum. Genet 70:1269-1276.

Vissers LE, de Vries BB, Osoegawa $K$, Janssen IM, Feuth T, Choy CO, Stratman $H$, van der Vhiet W, Huys EH, van Rijk A, Smeets D, wan Ravenswaaj-Arts CM, Knoers NV, van der Burgt I, de Jong PJ, Brumer $H G$, van Kessel AG, Schoenmakers EF, Valtman JA. 2003. Array-based comparative genonic hybridization for the genomewide detection of submicroscopic chromosomal abnomalities. Am J Hum Genet 73:1261-1270.

Wilska ML, Kaski MK. 2001. Why and how to assess the aeciological diagnosis of children with intellectual disability/mental retardation and other neurodevelopmental disorders: description of the Finnish approach. Eur J Paed Neurol 5:7-13.

Wilson GN, Cooley WC. 2000. Preventive nanagement of children with congenital anomalies and syndromes. Cambridge University Press, Cambridge,

Yoshida A, Kobayashi K, Manya $\mathbb{H}$, Taniguchi K, Kano $H$, Mizuno M, Inazu T, Mitsuhashi H, Takahashi S, Takenchi M, Hermann R, Straub V, Talim B, Voit T, Topaloglu H, Toda T, Endo T. 2001. Muscular dystrophy and neuronal migration disorder caused by mutations in a glycosyltransferase, POMGnT1. Dev Cell 1:717-724. 
SUMMARY 
Mental retardation (MR) originates before the age of 18 , and is a lifelong disability characterised by significant limitations both in intellectual functioning (IQ < 70 ) and in several areas of adaptive behavior. It has a major impact on the life of the affected individual and his/her social interaction with others.

Chapter 1 addresses general aspects of MR and gives an outline of this thesis. Worldwide, a prevalence of $0.38 \%$ has been established for severe $\mathrm{MR}$ ( $\mathrm{IQ}<50$ ) whereas the prevalence for mild MR (IQ 50-70) is up to $3 \%$ and varies widely. In the Netherlands, at least $0.7 \%$ of the population is mentally retarded. About half of them live in residential settings, with an increasing proportion of these living in small community-based groups. General practitioners and specialised Physicians for Persons with Intellectual Disabilities (Arts voor Verstandelijk Gehandicapten, AVG) are the most important medical care providers. Health problems are twice as frequent as in the general population and partly depend on the cause of the MR. This thesis provides an overview of the current state of the art of clinical genetic diagnostic investigations in MR. These comprise clinical evaluation, and cytogenetic, molecular and metabolic analyses. In addition to a general overview of each aspect, all of them will be illustrated by a representative study. The aim is both to promote diagnostic research in the field of the etiology of $M R$, and to provide a practical tool for care providers for mentally retarded persons.

In chapter 2, studies on the etiology of MR published since the beginning of the 1980s are reviewed. It is shown that the yield of the studies critically depends on the chosen methodology and classification, but even more on the use of the term diagnosis. A new, dynamic method of classification is proposed which includes the degree of certainty of a diagnosis. This novel method is meant to allow classification with a more transparent use of the term diagnosis, and to facilitate followup of patients.

Chapter 3 deals with the clinical evaluation of a mentally retarded patient. This includes assessment of the history, and a physical examination which focuses on observation, surface inspection, anthropometric measurements and a basic neurological examination. Phenotypic abnormalities such as malformations and minor anomalies are of particular importance. A multidisciplinary approach reflects the complex needs of a mentally retarded person. For institutionalised patients, the cooperation of the Physician for Persons with Intellectual Disabilities with the clinical geneticist is of particular importance. A distribution of their respective tasks is proposed. The clinical examination allows syndrome recognition, provides the basis for subsequent laboratory tests, and is essential for developmental research. 
For illustration, the brain malformations of oculocerebrocutaneous syndrome (OCCS), a rare neurocutaneous disorder, are reviewed. A consistent pattern of malformations could be delineated in the majority of patients. It comprises a complex forebrain malformation, and a novel mid-hindbrain malformation which is thought to be pathognomonic for OCCS. The delineated pattern of brain malformations allows differentiation from other syndromes and points to a defect of the mid-hindbrain organizer as the underlying pathogenetic mechanism.

In Chapter 4, a summary of cytogenetic studies in MR is given. Over the past more than 50 years, techniques have evolved from non-banded to high resolution banded chromosome analysis: nowadays, the latter is the gold standard. FISH techniques and all techniques derived from it play a major role. The report of a series of patients illustrates that the combined application of different classical cytogenetic techniques can enable the diagnosis of patients who were assumed to have a normall karyotype after their first investigation. Cytogenetically visible aberrations are found in roughly $10 \%$ of patients with MR.

During the last decade, it has been shown that in addition, cryptic subtelomeric abnormalities contribute significantly to the etiology of MR. Both a review of previously published studies and a retrospective study of the patients evaluated at the Department of Clinical Genetics at Maastricht, reveals a prevalence of subtelomeric rearrangements of about $5 \%$. The clinical presentation of all aberrations detected at Maastricht is reported, and the relevant literature reviewed. The interpretation of detected subtelomeric abnormalities may be complicated by different factors, such as the occurrence of variants and climical variability.

Chapter 5 concerns forms of MR that can be diagnosed by molecular analysis. Fragile X syndrome and other, well-known X-linked MR syndromes are briefly reviewed. The distinction between non-syndromic $X$-linked MR (MRX) with non-specific MR only, and syndromic X-linked MR (MRXS) with associated features, has been softened by the detection of at least 10 genes involved in both forms. Autosomal MR syndromes and non-syndromic forms of MR are also shortly discussed; so far, the latter ones have no clinical significance.

Mutations in the MECP2 gene cause Rett syndrome in female patients, and, much less frequently, MRXS and MRX in males. The phenotypic spectrum of neurodevelopmental disorders in males caused by $M E C P 2$ mutations is critically reviewed, and a case of a 21 year old male with male Rett variant is described. $M E C P 2$ analysis in a group of 72 males with unexplained combinations of $M R$ and different neurological features shows that even in this clinically highly selected group, MECP2 mutations are infrequently found. Rett variant may however be clinically underrecognised in males. 
Chapter 6 addresses the question whether and when adult patients with MR should be recommended for metabolic testing. Metabolic disorders are responsible for only a small fraction of MR, probably for less than $1 \%$. It has however been shown that they are associated with a remarkably broad phenotypic spectrum. A review of metabolic investigations performed over a 10-year period in adolescent and adult persons with MR confirms that targeted testing in a clinically selected group is appropriate. The spectrum of possible indicators however is broad, and a proposal is made for an adapted list of clinical findings which may indicate the need for metabolic testing.

Chapter 7 finally deals with the benefits of genetic evaluation of MR, and with future perspectives. The benefits of a causal diagnosis are numerous and comprise relief from uncertainty, optimisation of care procedures, genetic counselling and possibly prevention. Giving a name to the clinical problem seems to have an essential role. It is concluded that every person with $M R$ has the right to have an etiological evaluation.

Future perspectives will be dominated by the need for systematic approaches requiring standardization and classification in different fields, and by new technologies such as MLPA/MAPH and array-based technologies. The interpretation of the resulting flood of data will be a major demand on clinical geneticists. 
Mentale retardatie (MR) wordt beschouwd als een levenslange handicap die begint voor de leeftijd van 18 jaar, en wordt gekenmerkt door significante beperkingen van intellectuele vermogens $(1 Q<70)$ én van meerdere gebieden wan. adaptief gedrag. Het heeft en grote invloed op het leven van de aangedane persoon en op de sociale interacties met anderen.

Hoofdstuk 1 beschrijft de algemene aspecten van MR en geeft een overzicht van de inhoud wan dit proefschrift.

Wereldwijd is een prevalentie van $0.38 \%$ voor ernstige MR $(I Q<50)$ aangetoond, terwijl de prevalentie voor milde MR (IQ 50-70) in de verschillende studies sterk varieert en kan oplopen tot $3 \%$. In Nederland is minstens $0.7 \%$ van de populatie mentaal geretardeerd. De helft van deze personen verblijft in aangepaste instellingen, waarbij overigens het aandeel kleinschalige woonvormen steeds groter wordt. De meest belangrijke medische behandelaars zijn huisartsen en AVGs (Artsen voor Verstandelijk Gehandicapten). Medische problemen komen bij mensen met MR tweemaal zo vaak voor als in de algemene bevolking en houden deels verband met de oorzalk van de MR.

Dit proefschrift geeft een overzicht van de huidige stand van zaken van het klinisch genetisch onderzoek naar MR. Dit onderzoek omvat een klinische evaluatie, en cytogenetische, moleculaire en metabole laboratoriumtesten. Ieder onderdeel bevat een algemeen overzicht en wordt geillustreerd door een representatieve studie.

Dit proefschrift beoogt het diagnostisch onderzoek op het gebied van de etiologie van MR te bevorderen en een hulpmiddel aan te reiken voor de praktijk van hulpverleners voor mentaal geretardeerden.

In hoofdstuk 2 wordt een overzicht gegeven van studies naar de etiologie van MR die sinds het begin van de jaren' 80 verschenen zijn. Daaruit wordt duidelijk dat de gerapporteerde resultaten niet alleen in sterke mate afhangen van de methode en classificatie waarvoor gekozen werd, maar meer nog van het gebruik van de term 'diagnose'. Daarom wordt een nieuwe, dynamische manier van classificatie, die rekening houdt met de waarschijnlijkeid van de diagnose, voorgesteld. Door toepassing van deze nieuwe methode wordt de term "dagnose" transparanter en de follow-up van patiënten gemakkelijker.

Hoofdstuk 3 behandelt de klinische evaluatie van een patiënt met MR. Deze omvat het vastleggen van de voorgeschiedenis van de patiënt en het verrichten van lichamelijk onderzoek dat zich met name richt op observatie, inspectie, anthropometrische metingen en een basaal neurologische verkenning. Phenotypische afwijkingen zoals malformaties en kleine anomalië̈n zijn bijzonder belangrijk. Een multidisciplinaire aanpak is daarbij aangewezen en weerspiegelt 
de complexe behoeften van mensen met MR. Voor patienten in instellingen is de samenwerking tussen de AVG en de klinisch geneticus bijzonder belangrijk; een takverdeling tussen hen wordt voorgesteld. Het klinisch onderzoek leidt tot syndroomherkenning, is de basis voor verder beleid en laboratorium onderzoek, en is tevens essentieel voor wetenschappelijk onderzoek. Ter illustratie worden de hersenafwijkingen van patienten met het oculocerebrocutaan syndroom (OCCS), een zeldzaam neurocutaan syndroom, beschreven. Een consistent patroon van afwijkingen kon bij de meeste van deze patiënten worden aangetoond. Dit bestond uit een complexe afwijking van de voorhersenen en een unieke malformatie van het tectum en de kleine hersenen, die waarschijnlijk pathognomonisch is voor OCCS. De beschreven hersenafwijkingen onderscheiden OCCS van andere syndromen en wijzen naar een mogelijk pathogenetisch mechanisme.

In hoofdstuk 4 wordt een samenvatting van cytogenetische studies naar $M R$ gegeven. Tijdens de afgelopen 50 jaar hebben de technieken van chromosomenonderzoek zich ontwikkeld van niet-gebandeerde karyogrammen naar highresolution gebandeerde chromosomenanalyse, die tegenwoordig de gouden standaard is. Het FISH-onderzoek en andere technieken die hieruit ontstaan zijn, spelen een belangrijke rol bij de opheldering van chromosomale bevindingen. De opgenomen publicatie van een serie patienten illustreert dat de toepassing van gecombineerde cytogenetische methoden afwijkingen kan opsporen bij patiënten die bij een vroeger uitgevoerd onderzoek een nomaal karyotype toegekend hadden gekregen. Cytogenetisch zichtbare chromosoomafwijkingen worden bij grofweg $10 \%$ van patiënten met MR gevonden.

De afgelopen 10 jaar is bovendien aangetoond dat cryptische subtelomere chromosoomafwijkingen significant bijdragen aan de oorzaken van MR. Een overzicht van reeds gepubliceerde studies én een retrospectieve studie van patiënten die bij de afdeling Klinische Genetica Mastricht onderzocht zijn, laat een prevalentie van ongeveer $5 \%$ van subtelomere afwijkingen zien. De kliniek van alle Maastrichtse patienten met een subtelomere afwijking wordt beschrewen en een bijbehorend literatuuroverzicht gegeven. De interpretatie van de betekenis van subtelomere afwijkingen kan soms door verschillende factoren bemoeilijkt worden, zoals het voorkomen van varianten en klinische variabiliteit.

Hoofdstuk 5 betreft vormen van MR warvan de oorzaak met moleculain onderzoek vastgesteld kan worden. Fragiele X syndroom en andere bekende Xgebonden MR syndromen worden kort beschreven. Het onderscheid tussen niet-syndromale $X$-gebonden MR (MRX) met aspecifieke MR als enig kenmerk, en syndromale X-gebonden MR (MRXS) met bijkomende kenmerken vervaagt door de ontdekking dat minstens 10 genen bij beide vormen 
betrokken zijn. Autosomale MR syndromen en niet-syndromale vomnen van MR worden eveneens kort besproken; tot nu toe hebben de laatst genoemde geen betekenis in de klinische praktijk.

Mutaties in het MECP2 gen veroorzaken Rett syndroom bij vrouwen en, veel minder frequent, MRX en MRXS bij mannen. Het phenotypische spectrum van ontwikkelingsstoornissen bij mannen veroorzaakt door MECP2 mutaties, wordt kritiscil beschouwd. Daarnaast wordt de casus van een 21 -jarige jongeman met Rett variant beschreven. MECP2 genanalyse in een groep van 72 mannen met esn onverklaarde combinatie van MR en diverse neurologische verschijnselen lat zien dat MECP2 mutaties zelfs in deze klinisch goed geselecteerde groep maar zelden worden gevonden. Mogelijk is Rett variant wel ondergediagnostiseerd bij mannen.

Hoofdstuk 6 benadert de wrag of en wanneer volwassen mentaal geretardeerde patienten in aanmerking voor metabool onderzoek komen. Metabole aandoeningen zijn de oorzaak van slechts een klein deel van alle gevallen van MR, mogelijk minder dan 1\%. Deze tonen echter een opvallend breed phenotypisch spectrum. Een overzicht van metabole ondezoeken verricht in een periode van 10 jaar bij adolescenten en volwassen personen met MR bevestigt dat testen in een klinisch geselecteerde groep van patienten aangewezen is. Er is echter een breed spectrum van klinische bevindingen die op een mogelijke metabole aandoening kunnen wijzen. Een aangepaste lijst met dergelijke bevindingen wordt voorgesteld.

Hoofdstuk 7 tenslotte bediscussieert het nut van een genetische evaluatie naar MR en het toekomstig perspectief. Het belang van een juiste causale diagnose heeft zowel sociale als klinische aspecten. Te denken valt daarbij onder meer aan verlossing van onzekerheid, optimalisatie van behandling en begeleiding, erfelijkheidsvoorlichting en mogelijk preventie. De naamgeving speelt hierbij een cruciale rol. De conclusie is dat iedere persoon met $\mathrm{MR}$ recht op gedegen etiologisch onderzoek heeft.

Het toekomstig perspectief wordt bepaald door de behoefte aan systematische benaderingen die standaardisatie en classificatie op diverse gebieden vereisen, en door nieuwe technologieèn zoals MLPA/MAPH en op micro-array-gebaseerde technieken. De interpretatie van de resulterende overvloed van data zal een behoorlijk beroep doen op de kennis en kundigheid van klinisch genetici. 


\section{ACKNOWLEDGEMENTS}

Many people have contributed to this thesis by their support, their work, and by sharing their knowledge, and I feel very grateful to all of them.

In the first place, I am most thankful to the many patients and their families for their patience and cooperation - they have been my true masters.

All colleagues of the medical, cytogenetic, molecular and metabolic unit of the Department of Clinical Genetics in Maastricht: I would have been unable to write this book without you releasing me from parts of my usual duties, without your laboratory and secreterial work, your support and friendship, your time and ideas offered, your understanding and inspiration.

Prof.dr. Fryns, Jean-Pierre: synchronously, we developed the idea of this thesis. Warmest thanks for your stimulation and continuous encouragement when paving my way.

Prof.dr. Schrander-Stumpel, Connie: thanks for your support and for ineffaceably engraving upon my thinking and acting that patient care is the origin and primary goal of all our work.

Prof.dr. Geraedts, Joep: 1 am grateful for the discussions we have had - they have always shaped my arguments, taught me to aspire clarity and stimulated my academic work.

Dr. de Die-Smulders, dearest Christine: thanks for your support right from the beginning and for your efforts to turn a certain November day into a menorable, beautiful event.

Susi, sisterheart, I am happy that you have been my assistant for this period - it has given me such a good feeling that you have been literally and figuratively backing me.

The Physicians for Persons with Intellectual Disabilities in the different Centers across the region: I am happy that we have built up such good cooperation thanks for all your efforts. A special thank to Sybe Dijkstra: the months in Op de Bies have probably been the most important part of my training period - a residence with mentally retarded individuals should be obligatory for clinical genticists. 
Francis van der Lubbe: thank you so much for preparing endless numbers of illustrations for posters, papers and publications, particularly the cover of this thesis, and transforming them into pieces of art.

Dr. Derek Saunders: thanks for correcting and ironing one version after the other of the manuscript. These acknowledgements may be the only part of the thesis which has not passed your valuable native speaker's checking procedure.

Beloved family and friends - the irreplaceable ones to master the challenges of life and work! My deepest thanks to Florian, Tobias and Martin who spontanuously and continuously supported the idea of their mother to write a second thesis at an advanced age. 


\section{CURRICULUM VITAE}

Ute Moog was born in Leverkusen, Germany, on October 26, 1954. She grew up in an atmosphere inspired by books and music which also shaped her schooling. Between 1973 and 1980 she studied medicine in Germany, first in Saarbrücken, and after 1975, in Aachen. Her studies were funded by the Studienstiftung des Deutschen Volkes. Fascinated by the possibility of direct visualisation of defects underlying diseases, she chose as the topic of her first thesis "Chromosomenuntersuchung bei epileptischen Kindern mit Phenytoin-Monotherapie" under the supervision of Prof.dr. M. Habedank. She defended her dissertation and was awarded her doctoral degree by the Rheinisch Westfalisch Technische Hochschule Aachen in 1982.

A home-based period followed in which she raised her three sons, Martin, Tobias and Florian to self-sufficiency. During this time, she dedicated herself to music, playing and teaching the oboe, and performing chamber music semi-professionally.

In 1993, she returned to medicine, taking up a position in the Department of Clinical Genetics at the University Hospital in Maastricht. Between 1995 and 1999 she was a trainee in clinical genetics, and became registered as a clinical geneticist in 1999. Since that time, she has been a staff nember of this Department, as well as an extraordinary member of the medical staff in the Heerlen and Venlo hospitals. She has been happy to work and live more as a member of the European community than as a German or Dutch inhabitant, and to keep her sense of foreign languages vivid. The continuous close cooperation with the Center for Human Genetics in Leuven, Belgium, headed by Prof. dr. J.P. Fryns, has inspired her specialisation in genetic evaluation of mental retardation. This includes acting as an expert consultant for clinical genetics in various centers for the mentally retarded. Her research work which she regularly presents at international meetings, is summarised in this, her second thesis. 



\section{PUBLICATIONS}

Moog U, Engelen JJM, de Die-Smulders CEM, Albrechs JCM, Loneus WH, Haagen AAM, Raven EJM, Hamers AJH. 1994. Partial trisony of the short arm of chromosome 18 due to inversion duplicati on and direct duplication. Clin Genet 46:423-429.

Smeets DFCM, Mogg U, Weernaes CMR, Vaes-Peeters G, Merkx GFM, NiehofJP, Hamers G. 1994. ICF syndrome: a new case and review of the literature. Hum Genet 94:240-246.

Moog U. 1995. Was man über Erblichkeit wissen sollte. Monatszeitschrift des Landfratienverbandes Eupen, Februar 1995.

Moog $U_{n}$ Engelen J, Albrechts J, Hoorntje T, Hendrikse F, Schrander-Stumpel C. 1996. Alagille syrudrome in a family with duplication 20p11. Clin Dysmorphol 5:279-288.

Mogg U, Krïger G, Stengel B, de Die-Smulders C, Dijkstra S, Bleeker-Wagemakers E. 1996. Oculocerebrocutaneous syndrome: a case report, a follow-up, and differential diagnostic considerations. Genet Counsel 7:257-265.

Engelen JJM, Loots WJG, Motoh PCC, Moog U, Hamers GJH, Geraedts JPM. 1996. Marker chromosome identification by micro-FISH. Clin Genet 49:242-248.

Moog U, de Die-Smulders C, Systermans JMJ, Cobben JM. 1997. Oculocerebrocutaneous syndrome: report of three additional cases and aetiological coniderations. Clin Genet 52:219-225.

Moog U, Bleeker-Wagemakers EM, Crobach P, Vles JSH, Schrander-Stumpel CTRM. 1998. Sibs with Axenfeld-Rieger anomaly, hydrocephalus, and leptomeningeal calcifications: a new autosonal recessive syndrome? Am J Med Genet 78:263-266.

Moog U, Schoonbrood-Lenssen AMI, Schrander-Stumpel CTRRM, Fryns JP. 1998. Spasticity, mental retardation, macrocephaly and distinct craniofacial appearance: confirmation of a new subtype of complicated spastic paraplegia? Genet Counsel 9:211-213.

Moog U, Schoonbrood-Lenssen AMJ, Wagemans A, Spaapen LIM, de Die-Smulders CEM. 1998. De ziekte van Sanfilippo type $B$ : ondergediagnostiseend bij verstandelijk gehandicapten? Nederlands Tijdschrift voor de Zorg aan verstandelijk gehandicapten 24: $161-166$.

Thissen MRTM, Jonkman MF, Moog U. Epidermolysis bullosa met vlekkige pigmentatie. Ned Tijdschr Dermatol Venerol 1998;8:152-153. 


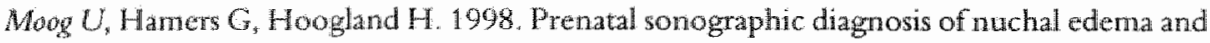
double ancuploidy $(48, \times X Y,+21)$ : discrepancy between results of chorionic villi and amniotic fluid sampling. I Clin Ultrasound 26:228-229.

Moog U, de Die-Smulders CEM, Scheffer H, van der Vlies P. Henquet CJM, Jonkman MF. 1999. Epidermolysis bullosa simplex with mottled pigmentation: chinical aspects and confirmation of the P24L mutation in the KRT5 gene in further patients. AmJ Med Genet 86:376-379.

Moog U, Maroteaux P, Schrander-Stumpel CTRM, van Ooij A, Schrander JJP, Fryns JP. 1999. Two sibs with an unusual pattern of skeletal malformations resembling osteogenesis. imperfecta: a new type of skeletal dysplasia? J Med Genet 36:856-858.

Van Kuilenburg ABP. Vreken P. Abeling NGGM, Bakker HD, Meinsma $\mathbb{R}$, Van Lenthe $H$, De Abreu RA, Smeitink JA, Kayserili H, Apak MY, Christensen E, Holopaien I, Pulkkj K. Riva D, Botteon G, Holme E, Tulinius M, KJeyer WI, Beemer FA, Duran M, NiezenKoning KE, Smir GPA, Jacobs C, Moog U, Spaapen LJM, Van Gennip AH. 1999. Genotype and phenotype in patients with dihydropyrimidine dehydrogenase deficiency. Hum Genet 104:1-9.

Mogg U, Engelen JJM, Albrechts JCM, Baars LGM, de Die-Smulders CEM. 2000. Familial dup (8) (p 12p21.1): mild phenotypic effect and review of partial 8 p duplications. Am J Med Genet 94:306-310.

Engelen JJM, Moog U, Evers JLH, Dassen H, Albrechts JCM, Hamers AJH. 2000. Duplication of chromosome region 8p23.1->p23.3: a benign variant? Am J Med Genet 91:18-21.

Curfs LMG, Mogg U, Didden R. 2001. Slapstoomissen bij een genetisch bepaalde verstandelijke handicap. In: Cure \& care development: slaap en slaapproblennen. Bohn Stafleu van Loghum, hoofdstuk 8, p85-104.

Liidecke HJ, Schaper J, Meinecke P, Momeni P, Groß S, van Holtum D, Hirche H, Abramowicz MJ, Albrecht B, Apacik C, Christen HJ, Claussen U, Devriendt K, Fastnacht E, Forderer A, Friedrich U, Goodship J, Greiwe M, Hamm H, Hennekam R CM, Hinke] GK, Hoeltzenbein M, Kayserili H, Majewski F, Mathieu M, McLeod R, Midro AT, Moog U, Nagai T, Niikawa N, Orstavik KH, Plöchl E, Seitz C, Schmidtke J, Tranebjaerg L, Tsukahara M, Wittwer B, Zabel B, Gillessen-Kaesbach G, Horsthemke B. 2001. Genotypic and phenotypic spectrum in the tricho-thino-phalangeal syndromes types I and III. Am J Hum Genet 68:81-91.

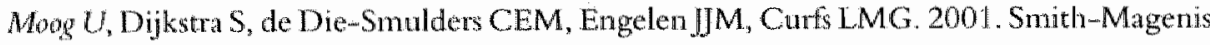
syndtroom. Nederlands Tijdschrift voor de Zorg aan verstandelijk gehandicapten 27:147155.

Lopez-Correa C, Dorachner M, Brems $H_{*}$ Lazaro C, Clementi M, Upadhyaya M, Dooijes D, Moog U, Kelarer-Sawatzki H. Rutkowski JL, Fryns JP, Marynen P, Stephens K, Legius E. 2001. Reconbination hotspot in NFI microdeletion patients. Hum Mol Genet 10:13871392.

Moog $U$, de Die-Smulders CEM, Schrander-Stumpel CTRM, Engelen JJM, Hamers AJH, Frints S. Fryns JP. 2001. Holoprosencephaly: the Maastricht experience. Genet Counsel 12:287-298. 
De Die-Smulders CEM, Moog U, Engelen JJM, Peters JIM, Damen A. Vos W. Fryns JP. 2001 . Lateral facial clefts: a case report. Genet Counsel 12:163-165.

Moog U, Jansen NJG, Scherer G, Schrander-Stumpel CTRM. 2001. Acamponelic Campomelic Syndrome. Am J Med Gener 104:239-245.

Marcelis CLM, van der Putten HWHM, Tops C, Lutgens LCHW, Moog U. 2001. Chenotherapy resistant ovarian cancer in carriers of an LMSH2 mutation? Fan Cancer 1:107109.

Moog U, Dijkstra S. 2002. Klinisch genetisch onderzoek: samenwerking tussen AVG en klixisch geneticus. TVAZ 20:5-7.

Verhoewen WMA, Moog U, Wagemans AMA, Tuinier S. 2002. Wolf-Hirschhorn (4p-) syndrome in a near adult with major depression; succesful treatment with Citallopran. Genet Counsel 13:297-301.

Huang $T$, Lin AE, Cox GF, Golden WL, Feldman GL, Moog $U$, Schrander-Stumpel C, Kamisago M, Vermeulen SJ. 2002. Cardiac phenotypes in chromosome 4q-syndrome with and without a deletion of the dHAND gene. Genet Med 4:464-467.

Moog U, Engelen JJM, van Schrojenstein Lantman-de Valk HMJ, Driessen SD, Fryns JP. 2003. Familial cryptic translocation with deletion $4 \mathrm{q} 33->4 \mathrm{q}$ ter and duplication $7 \mathrm{q} 34->7 \mathrm{qter}$ in brothers with mental retardation, macrocephaly and iriscoloboma. Clin Dysmorphol $12: 35-39$.

Moog U, Smeets EEJ, van Roozendaal KEP, Schoenmakers S, Herbergs I, SchoonbroodLenssen AMJ, Schrander-Stumpel CTRM. 2003. Neuro-developmental disorders in males related to the gene causing Rett syndrome in fenales (MECP2). Eur J Paed Neurol $7.5-12$.

Marcelis C, Forget $\mathbb{P}$, Moog U. 2003. Alagille syndroom: klinische en genetische aspecten. Ned Tijdschr Kindergeneeskd 71:57-62.

Moog U, Engelen JJM. 2003. Chromosomenonderzoek anno 2003. TVAZ 21:9-14.

Schrander-Stumpel CTRM, Curfs LMG, Moog U, Geraedts JPM. 2003. Klinisch-genetisch onderzoek bij mensen met een verstandelijke handicap. Vademecum Zorg voor Verstandelijk Gehandicapten april 2003:9200-1 16.

Engelen JJM, Moog U, Weber J. Haagen AAM, Hamers AJH. 2003. Deletion of chromosome region $18 \mathrm{q} 21.1-18 \mathrm{q} 21.3 \mathrm{in}$ a patient without clinical features of the $18 \mathrm{q}-\mathrm{p}$ henotype. Am IMed Genet 119A:356-359.

Moog U, Engelen JJM, Schrander-Stumpel CTRM, Fryns JP. 2003. Chromosome bands and ends revisited. Am J Med Genet 121A:88-89.

Smeets E, Schollen E, Moog U, Matthijs G, Herbergs J, Smeets H, Curfs L, Schrander-Stumpel C. Fryns JP. 2003. Rett syndrome in adolescent and advalt females: chinical and molecular genetic Endings. An J Med Gertet 122A:227-233.

Van Roosmalen MS, Stalmeier PFM, Verhoef LCG, Hoekstraw Weebers JEHM, Oosterwijk JC, Hoogerbrugge N, Moog U, van Daal WAJ 2004. Impact of BR CA1/2 testing and disclosure of a positive test result on women affected and unaffected with breast or ovarian cancer. Am J Med Gener 124A:346-355. 
Van Roomalen MS, Stalmeier PFM, VerhoefLCG, Hoekstra-Weebers JEHM, Oosterwijk JC. Hoogerbrugge $\mathrm{N}_{s}$ Moog $U$, van Daal WAJ. 2004. Randomised trial of a decision aid and its timing for wonen being tested for a BRCA $1 / 2$ mutation. British Joumal of Cancer 90.333-342.

Moog U, Engelen JM, Weber BW, Gelderen M wan, Steyaert J, Baas F, Sijstermans HMJ, Fryns JP. 2004. Hereditary motor and sensory neuropathy (HMSN) IA, developmental delay and autism related disorder in a boy with duplication (17) (p11.2p12). Genet Counsel 15.73-80.

Van Roosmalen MS, Stalmeier PFM, Verhoef LCG, Hoekstra-Weebers JEHM, Oosterwijk JC, Hoogerbrugge N, Moog U, wan Daal WAJ. 2004. Randomized trial of a shared decision making intervertion, consisting of trade-offs and individualized treatment informaw. tion, for BRCA1/2 mutation carriers. J Clin Oncol 22;3293-3301.

Dols-Caanen B, Moog U, Gomez Garcia E. 2004. Vervolgkeuzes van BRCA-mutatiedraagsters. Oncologica 21:87-90.

Schrander-Stumpel CTRM, Curs LMG, Moog U, Geraedts JPM. 2004. Klinisch genetisch onderzoek bij mensen met een verstandelijke handicap. Balans en Perspectief, Stichting St. Anna, hoofdstuk 11, p201-211.

Sneets E, Terhal P, Casaer P, Peters A, Midro A, Schollen E, van Roozendal K, Moog $U$, Matthijs G, Herbergs J, Smeets H, Curfs L, Schander-Stumpel C, Fryns JP. 2005. Rett syndrome in females with CTS hot spot deletions: a disorder profile. Am J Med Genet 132A:117-120.

Stalmeier PFM, Van Roosmalen MS, Verhoef LCG, Hoekstra-Weebers JEHM, Oosterwijk JC, Moog U, Hoogerbrugge N, van Daal WAJ. 2005. On the evaluation of shared decision making: the decision evaluation scales. Patient Educ Couns 57:286-293.

Moog U. 2005. The ontcome of diagnostic studies on the etiology of mental retardation: Considerations on the classification of the causes. Am I Med Genet 137A:228-231.

Moog U, Jones MC, Bird L, Dobyns WB. 2005. Oculocerebrocutaneous syndrome: the brain malformation defines a core phenotype. J Med Genet May 6 [Epub aheand of print]

Mog U, Arens YHJM, wan Lent-Albrechts JCM, Huijts PEA, Smeets EEJ, SchranderStumpel CTRM, Engelen JJM 2005. Subtelomeric chromosome aberrations: still a lot to leam. Clin Genet, August 25 (online publication date). 
